UNIVERSIDAD DE GRANADA

Arquitectura religiosa mudèjar de la Costa de Granada

Presentado por:

D./Dª . Raúl Rodríguez Sánchez

Curso académico_2018_/_2019_ 


\title{
Arquitectura religiosa mudéjar de la Costa de Granada
}

\author{
Autor: Raúl Rodríguez Sánchez
}

Máster Universitario en Tutela del Patrimonio Histórico-Artístico. El Legado de Al-Ándalus

Tutor: Don Rafael López Guzmán.

Firma del tutor: 


\section{INDICE}

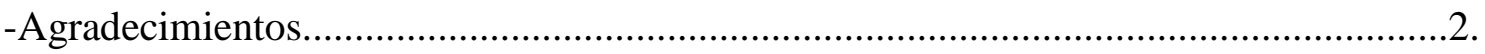

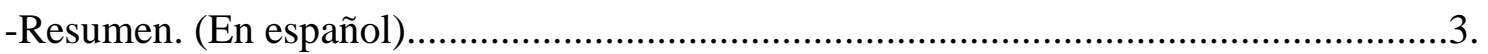

1. Introducción. (Antecedentes y objetivos)......................................................

2. Metodología y proceso de investigación.............................................................

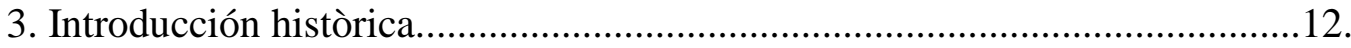

4. Medio físico y geografía històrica.................................................................21.

5. Iglesias mudéjares..............................................................................23

5.1. Iglesia Parroquial de San José de Lentegí.......................................23.

5.2. Iglesia Parroquial de Nuestra Señora de la Concepción de Otívar..37.

5.3. Iglesia Parroquial de San Antonio de Jete.......................................47.

5.4. Iglesia de Nuestra Señora del Rosario de Salobreña........................57.

5.5. Iglesia de San Antonio de Lobres..................................................69.

5.6. Iglesia de San Antonio de Padua de Guájar Fondón........................77.

5.7. Iglesia Matriz de San Lorenzo de Guájar Faragüit..........................86.

5.8. Iglesia de Nuestra Señora de la Encarnación de Guájar Alto..........97.

5.9. Iglesia Mayor Parroquial de la Encarnación de Motril...................106.

5.10. Convento e Iglesia de los Franciscanos Mínimos de la Victoria de

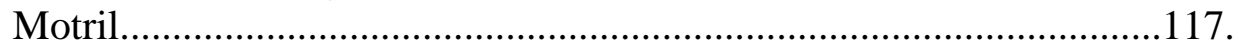

5.11. Iglesia de la Divina Pastora (Convento de Capuchinos)

de Motril

5.12. Iglesia del Santísimo Cristo de Cabrilla de Lújar..........................131.

5.13. Iglesia Parroquial de San Miguel de Gualchos.............................139.

5.14. Iglesia Parroquial de la Inmaculada Concepción de Rubite........148.

5.15. Iglesia de Nuestra Señora del Rosario de Polopos........................155.

5.16. Iglesia Parroquial de San Cayetano de Sorvilán............................164.

5.17. Iglesia Parroquial San Luis Rey de Francia de Albondón............174.

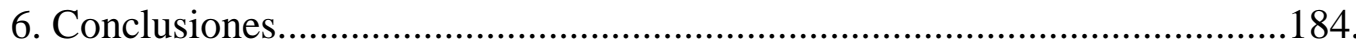

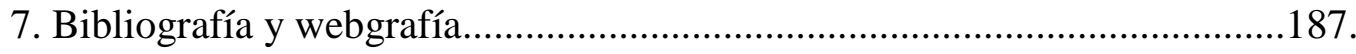




\section{Agradecimientos.}

En primer lugar, quisiera dar las gracias en este trabajo a mi familia y amigos por todo el apoyo, ánimo y fuerza que me ha mostrado en todo el proceso de realización, pero no solo en él sino en el propio Máster, pero de una manera especial a mi padre, Don Miguel Ángel Rodríguez Fernández, por ser mi compañero de camino en el trabajo de campo para la investigación de cada una de las iglesias, sin él esto no hubiera sido posible.

Por su puesto, dar la gracias a Don Rafael López Guzmán, catedrático de Historia del Arte de la Universidad de Granada y especialista del objeto de este trabajo, sin su ayuda y guía no hubiera podido confeccionar un buen trabajo, sus buenos consejos me han llevado por buen camino.

Dar las gracias también a cada uno de los sacerdotes que regentan las iglesias que he estudiado y a los que les pedí permiso para poder investigar y recoger documentación gráfica, por su gran acogida, disponibilidad y disposición para realizar el trabajo que requería hacer: a Don Néstor Robledo Robledo, sacerdote de Lentegí, Otívar y Jete; a Don Jorge Nieto García, sacerdote de Salobreña; al Sacerdote de Lóbres; a Don Lorenzo Pablo Márquez Garrido, sacerdote de Los Guájares; a Don Daniel Escobar Gutiérrez y Don José de Jesús Martínez, sacerdotes de Lújar, Gualchos y Rubite; a Don Fernando Rodríguez Fernández, sacerdote de Polopos y Sorvilán; y a Don Alejandro Pablo Anguis Rodríguez, sacerdote de Albondón.

Y por supuesto a cada una de las personas de esos pueblos que me han aportado información bastante importante para la investigación y el análisis de las iglesias y que lo hicieron de forma desinteresada. 


\section{Resumen.}

El presente trabajo pretende hacer un análisis de las iglesias mudéjares de la costa de la provincia de Granada, pero para ello hemos querido primeramente hacer una introducción histórica de la situación de los musulmanes tras la conquista cristiana de este territorio costero tanto como mudéjares como moriscos, situación bastantes negativa tanto para unos como para otros debido a los enfrentamientos que tuvieron por la falta de entendimiento y por el incumplimiento por parte de los castellanos de los acuerdos pactados. Pero estas iglesias como es lo lógico están situadas en pueblo y por esta razón hemos querido hacer un breve apartado en el que describimos física y geográficamente esta costa de Granada, caracterizada principalmente por estar rodeada de montañas y sierras.

A continuación, ya pasamos a describir propiamente cada iglesia, desde la zona de Almuñecar, con Lentegí, Otívar, Jete, pasando por Salobreña, Lobres, Los Guájares (Guájar Fondón, Guájar Faragüit, Guájar Alto), Motril, Lújar, Gualchos, Rubite, Polopos, Sorvilán y Albondón. En cada descripción destacamos la fecha de construcción, sus materiales, sus plantas, y las descripciones del exterior con sus cajones de mampostería, las cintas de ladrillo y yeso y sus portadas o fachadas principales; del interior, sus armaduras con sus peculiaridades, el alfarje del coro, la capilla mayor, las naves laterales, las bóvedas, arcos, y las decoraciones que podrían presentar; así como una descripción de la torre. El análisis presenta el estado actual de la iglesia, su evolución a lo largo del tiempo, y lo propiamente mudéjar, que ha podido ser ocultado o destruido como hemos podido comprobar en algunos casos. Destacando por último lo que configura a la iglesia como mudéjar.

Palabras clave: armadura, alfiz, alfarje, yeso, ladrillo. 


\section{Introducción (Antecedentes y objetivos).}

- Antecedentes.

En la presentación de los antecedentes en primer lugar trataremos de exponer la parte lo que se ha escrito de la historia de la Costa de la provincia de la Granada, para pasar a tratar de las iglesias mudéjares de las distintas poblaciones de esta zona de Granada.

\section{- Historia:}

En primer lugar, hemos de citar a Julio Caro Baroja, que ha trabajado entre otros temas sobre los moriscos en el reino de Granada. En lo referente a nuestro ámbito de estudio, no lo trata de forma directa, pero si menciona datos de interés. ${ }^{1}$ José Enrique López de Coca Castañer ha estudiado la fiscalidad en el reino de Granada, en el que de nuestro ámbito de estudio no lo trata directamente pero si menciona datos que son de nuestro interés. ${ }^{2}$ También, Ángel Galán Sánchez ha trabajado sobre el estatus de los musulmanes bajo el reino de Castilla una vez conquistado el reino de Granada, donde nos presenta a la propia población mudéjar, el marco jurídico, la división administrativa, las estructuras socioeconómicas y de poder, las colaboraciones entre comunidades, los conflictos y las conversiones forzosas de 1500. Con respecto a nuestro tema de estudio, aunque no lo aborda directamente hace mención a algunos datos de interés. ${ }^{3}$ También ha

${ }^{1}$ Sociedad y sistema de vida del nuevo estatus de los musulmanes que obtuvieron tras las conversiones forzosas auspiciadas por el Cardenal Cisneros y en el esto pararon a denominarse morisco. Estos datos aparecen en su libro:

- $\quad$ CARO BAROJA, Julio. Los Moriscos del reino de Granada. Madrid: Ediciones Itsmo, S.A., 1991.

${ }^{2}$ El sistema fiscal durante la etapa mudéjar es el mismo que en época islámica, pero en la Costa de Granada se añadió el impuesto de la Farda Costera, además del pago de los daños sufridos por los piratas y por las propias sublevaciones de sus conciudadanos mudéjares de esas mismas tierras. Estos datos aparecen en el documento:

- $\quad$ LÓPEZ DE COCA CASTAÑEZ, José Enrique. "La fiscalidad mudéjar en el reino de Granada”. En: V Simposio Internacional de Mudejarismo. Teruel: Instituto de Estudios Turolenses, 1991, págs. 191-220.

${ }^{3}$ La fecha de las Capitulaciones de Rendición de la Costa de Granada que fueron entre 1488 y 1489; la división del reino en alquerías, lo datos en cifras de la población mudéjar. Datos del autogobierno de esta población, de sus representantes en las zonas rurales, los poderes que tenían, los principales colaboradores y quienes eran los más influyentes en medio de la comunidad. Nos menciona, a su vez, los conflictos que había entre comunidades, las leyes que se impusieron a los mudéjares de la Costa, como fue la Farda Costera, la prohibición de moverse sin declarar la procedencia, la obligación de aportar guardar para la propia defensa de la Costa y la colaboración en esta defensa. Así como también las actitudes de algunos de los cristianos que practicaban la confiscación de tierras, los secuestros y los robos hacia los mudéjares. Estos datos aparecen en su libro:

GALÁN SÁNCHEZ, Ángel. Los mudéjares del Reino de Granada. Granada: Universidad de Granada, Diputación Provincial de Granada. 1991. 
trabajado sobre la problemática del cambio social que vivieron los mudéjares tras las conversiones forzosas al cristianismo, en el que no menciona directamente nuestro objeto de análisis, pero si nos da datos que lo influyen. ${ }^{4}$

A su vez, Miguel Ángel Laredo Quesada ha trabajado sobre los bautismos de los musulmanes granadinos en 1500 en el que tampoco trata directamente sobre nuestro objeto de estudio aunque nos aporta importantes datos. ${ }^{5}$ Isabel Montes RomeroCamacho estudió sobre las comunidades mudéjares en la Corona de Castilla durante el s. XV, en el no analiza directamente nuestra zona de investigación, pero nos refiere datos generales que la influyen considerablemente. ${ }^{6}$ Rafael G. Peinado Santaella, Antonio Domínguez Ortiz, Joaquín Bosque Maurel, Amparo Ferrer Rodríguez, Cristóbal González Román, Camilo Álvarez de Morales, María Jesús Viguera Molins, Miguel Ángel Laredo Quesada, Emilio Molina López, Antonio Malpica Cuello, Carmen Trillo San José, José Miguel Puerta Vílchez, Encarnación Motos Guirao, Manuel González Jiménez, Ángel Galán Sánchez, Enrique Pérez Boyero, José María Ruiz Povedano y Rafael Marín López han trabajado sobre la historia del reino de Granada desde los orígenes hasta la época mudéjar (hasta 1502) no tocando directamente a la Costa de Granada, pero Rafael G. Peinado Santaella y José María Ruíz Povedano nos aportan datos relevantes. ${ }^{7}$ También, Manuel Barrios Aguilera, Ernest Belenguer Cebriá,

${ }^{4}$ Las conversiones forzosas al cristianismo por parte de los musulmanes en el reino de Granada en el contexto de Europa. Nos aporta datos de los mudéjares y de los moriscos y sus problemáticas, donde nos hablas entre otras cosas de: la división en tres grupos de los colaboradores con la Corona de Castilla que son, los grandes sublevados de la ciudad de Granada, los alfaquíes y alguaciles presentes en las comunidades rurales, y los que tienen influencia económica y reciben un trato especial por parte de la Corona; nos remite a las conversiones forzosas como algo que ha venido de la idea de unificación social, religiosa, política y económica del territorio y de Europa; de la creencia que estas conversiones era verdaderas; de las Capitulaciones de Conversión; y del cambio de condición al nuevo estatus de los musulmanes ahora denominados moriscos. Estos datos aparecen en su libro:

- GALÁN SÁNCHEZ, Ángel. Una sociedad en transición: los granadinos de mudéjares a moriscos. Granada: Universidad de Granada. 2010.

${ }^{5}$ Las conversiones forzosas llevadas a cabo por el Cardenal Cisneros y que recibieron el apoyo de parte de la Corona, provocando el alzamiento de los mudéjares del Albaicín en 1500, fueron el punto de partida para las posteriores conversiones forzosas. Estos datos aparecen en su documento:

- LADERO QUESADA, Miguel Ángel. "Los Bautismos de los musulmanes granadinos en 1500". En: VIII Simposio Internacional de Mudejarismo, De mudéjares a moriscos: una conversión forzada. Teruel: Centro de Estudios Mudéjares, 1999, págs. 481-542.

${ }^{6}$ Los factores de la ruptura de la convivencia en el reino de Granada durante el periodo mudéjar por el hecho de no poner en práctica por parte de los castellanos de lo acordado en las Capitulaciones. Este dato aparece en su documento:

MONTES ROMERO-CAMACHO, Isabel. "Las comunidades mudéjares en la corona de Castilla durante el s. XV”. En: VIII Simposio Internacional de Mudejarismo, De mudéjares a moriscos: una conversión forzada. Teruel: Centro de Estudios Mudéjares, 1999, págs. 367-480.

${ }^{7}$ Rafael G. Peinado Santaella nos habla del establecimiento de todo un sistema de repoblamiento de castellanos en las alquerías, de los estados de convivencia entre comunidades y los conflictos entre 
Bernard Vincent, Francisco Andújar Castillo, Julián Pablo Díaz López, Javier Castillo Fernández, Antonio Muñoz Buendía, José Szmolka Clares, Francisco Javier Martínez Medina, María Isabel Pérez de Colosía Rodríguez, José Manuel Gómez-Moreno, Valeriano Sánchez Ramos, Joaquín Gil Sanjuán, Rafael Benítez Sánchez-Blanco, Juan Luis Castellano Castellano, Juan Jesús Bravo Caro, Margarita María Birriel Salado, Juan García Latorre, Enrique Soria Mesa y José Antonio González Alcantud han trabajado sobre la historia del reino de Granada desde la época morisca hasta la repoblación (1502-1630) en el que tampoco abordan a la Costa de Granada de forma directa, pero Javier Castillo Fernández, que trata sobre sobre las estructuras sociales de los moriscos, nos dan datos gran consideración. ${ }^{8}$

- Iglesias mudéjares:

En los antecedentes del estudio sobre las Iglesias mudéjares de la costa de Granada hay diferentes estudios y análisis, de tal manera que vamos a hacer un breve repaso por cada uno de ellos.

En primer lugar hemos de citar a Manuel Domínguez García que ha trabajado sobre la evolución constructiva de la Iglesia Mayor Parroquial de la Encarnación, que aunque no es tema de nuestro estudio directo, si nos aporta datos importantes. ${ }^{9}$ José Manuel Gómez-Moreno trató sobre la arquitectura religiosa en la crisis del Renacimiento, donde menciona directamente uno de los templos del ámbito de nuestro

ellas. José María Ruíz Povedano trata sobre las ciudades y el poder municipal, de las poblaciones que están divididas en alquerías; y también sobre las Capitulaciones de rendición. A parte nos habla de que las medinas (ciudades islámicas) eran un número menor en periodo islámico, pero que tras la conquista se convirtieron en la principal entidad de ordenamiento del territorio. Estos datos aparecen:

- PEINADO SANTAELLA, Rafael G. "La sociedad repobladora: el control y la distribución del espacio". En: PEINADO SANTAELLA, Rafael G. (Coord.). Historia del Reino de Granada I: De los orígenes a la época mudéjar (hasta 1530). Granada: Editorial Universidad de Granada, El Legado Andalusí. 2000, págs. 477- 524.

- $\quad$ RUÍZ POVEDANO, José María. "Las ciudades y el poder municipal”. En: PEINADO SANTAELLA, Rafael G. (Coord.). Historia del Reino de Granada I: De los orígenes a la época mudéjar (hasta 1530). Granada: Editorial Universidad de Granada. 2000, págs. 611 660.

${ }^{8}$ Estratificación social de los moriscos. Estos datos aparecen en:

- CASTILLO FERNÁNDEZ, Javier. "Las estructuras sociales”. En: BARRIOS AGUILERA, Manuel (Coord.). Historia del Reino de Granada II. La época morisca y la repoblación (1502-1630). Granada: Editorial Universidad de Granada, El Legado Andalusí. 2000. Págs. 179-230.

${ }^{9}$ Estado primitivo y actual de la Iglesia Mayor Parroquial de la Encarnación de Motril. Estos datos aparecen en:

DOMÍNGUEZ GARCÍA, Manuel. La Iglesia Mayor de Motril: cinco siglos de evolución histórica de su fábrica. Motril: El Autor, 1983. 
estudio, dándonos importantes datos sobre el mismo. ${ }^{10}$ También, el mismo Manuel Domínguez García, junto con Domingo A. López Fernández, Encarnación Escañuela Cuenca, Juan José Ayala Carbonero, Juan J. López-Guadalupe Muñoz, José Policarpo Cruz Cabrera trabajaron conjuntamente sobre el Patrimonio histórico artístico de Motril, en el que, entre ellos el propio Manuel Domínguez García ahonda directamente en temas de nuestro estudio, aportando datos relevantes. ${ }^{11}$

A su vez, Rafael López Guzmán coordinó una importante guía sobre Granada y su provincia, donde colaboraron otros investigadores, que cita y analiza bastantes de los edificios aquí estudiados. ${ }^{12}$ Rafael López Guzmán junto con Ignacio Henares Cuéllar han trabajado sobre la Arquitectura Mudéjar en Granada, donde hacen mención directamente al objeto de nuestro estudio ${ }^{13}$; aunque también Rafael López Guzmán trabaja amplia y pormenorizadamente sobre la Arquitectura Mudéjar en cuyo análisis

${ }^{10}$ Se refiere a la iglesia de Jete. En su análisis hace una breve referencia histórica tanto de la iglesia primitiva que fue destruida por los moriscos, como de la que se construyó después de dicho alzamiento, aportando también un plano de la primitiva iglesia. Estos datos aparecen en:

- GÓMEZ-MORENO CALERA, J.M. La arquitectura religiosa granadina en la crisis del Renacimiento (1560/1650). Granada: Editorial de la Universidad de Granada, 1989.

11 * Iglesia Mayor Parroquial de la Encarnación: los datos que nos aporta son, el contexto histórico, la historia constructiva, descripción a lo largo de los siglos y descripción del estado actual. Estos datos aparecen en:

- DOMÍNGUEZ GARCÍA, Manuel. “La Iglesia Mayor de la Encarnación”. En: VV.AA. El Patrimonio artístico de Motril. Motril: Ayuntamiento de Motril. Área de Cultura y Patrimonio, 2003. págs. 47-57.

* Convento e Iglesia de la Victoria: contexto histórico y descripción actual. Estos datos aparecen en:

- DOMÍNGUEZ GARCÍA, Manuel. "La Iglesia de la Victoria”. En: VV.AA. El Patrimonio artístico de Motril. Motril: Ayuntamiento de Motril. Área de Cultura y Patrimonio, 2003. Págs.. 79-87.

* Iglesia de Capuchinos: contexto histórico y descripción actual. Estos datos aparecen en:

- DOMÏNGUEZ GARCÍA, Manuel. "La Iglesia de Capuchinos". En: VV.AA. El Patrimonio artístico de Motril. Motril: Ayuntamiento de Motril. Área de Cultura y Patrimonio, 2003. págs., 159-165.

${ }^{12}$ Nos encontramos con comentarios e información bastante importante de todas y cada una de las iglesias mudéjares que estamos estudiando. Nos aportan fechas de construcción, el número de naves, el tipo de cubiertas, número y características de las fachadas, el tipo de armaduras, disposición y descripción de la torre, las posibles destrucciones y reconstrucciones que hayan sufrido, el posible cambio de ubicación (si los ha habido), el tipo de arcos. La secuencia del orden en el que tratan estas descripciones de las iglesias es la siguiente: Jete, Lentegí, Otívar, Los Guájares, Motril, Salobreña, Albondón, Gualchos, Lújar, Polopos, Rubite y Sorvilán. Estos datos aparecen en:

- VV.AA. Guía artística de Granada y su provincia, Vol. II. Granada: Fundación José Manuel Lara. 2006.

${ }^{13}$ En primer lugar hacen una introducción histórica, para referirse claramente a la arquitectura mudéjar con todas sus características: Ordenanzas, el lenguaje constructivo, con todos los elementos que lo componen, y las iglesias mudéjares donde nos proporcionan información de las tipologías que hemos podido ver reflejado en las iglesias analizadas en nuestro trabajo, así como de la descripción de una de ellas concretamente, como es la Iglesia del Santísimo Cristo de Cabrilla de Lujar:

HENARES CUÉLLAR, Ignacio; LÓPEZ GUZMAN, Rafael. Arquitectura Mudéjar

Granadina. Granada: Caja de Ahorros y Monte de Piedad de Granada, 1989. 
aborda tema relevantes para nuestro estudio. ${ }^{14}$ Domingo Antonio López Fernández estudió la historia del Convento e Iglesia de los Mínimos de San Francisco de Paula de Motril, de tal manera que aborda directamente está iglesia y convento, objeto de nuestro estudio aportándonos datos considerables. ${ }^{15}$ Y por último, Mariano Martín García ha trabajado sobre las iglesias fortificadas de la costa de Granada, abordando directamente algunas de los templos que son objeto de nuestro estudio, de tal manera que nos aporta grandes datos sobre ellas. ${ }^{16}$

Hemos de indicar que toda esta documentación hace referencia a nuestro objeto de estudio y lo tratan ya sea de forma directa o indirecta, y lo hemos utilizado como fuente de datos para nuestra investigación, aportes que nos muestran como tanto la historia del Reino de Granada como de las Iglesias mudéjares de la costa de la provincia de Granada han sido objeto de estudio por numerosas personas y siguen siendo objeto de estudio y son de gran interés.

\section{- Objetivos.}

Así los objetivos de este trabajo una vez analizado la documentación que hay al respecto de estos temas son los siguientes:

${ }^{14}$ Nos describe brevemente la Historia del Reino de Granada desde las Capitulaciones de Rendición hasta la Expulsión de los Moriscos, pasando por la Guerra de las Alpujarras, con todas sus consecuencias, algo que afectó también a la Costa de Granada; así como las tipologías de iglesias mudéjares que se encuentran en este territorio en el que se incluye la Costa, aunque éste no aparezca mencionado de forma directa. Estos datos aparecen en:

- LÓPEZ GUZMÁN, Rafael. Arquitectura Mudéjar. Madrid: Ediciones Cátedra (Grupo Anaya, S.A.), 2000.

${ }^{15}$ Descripción de cómo era el convento de los Mínimos de San Francisco de Paula antes de su destrucción en la Guerra Civil en su estructura, elementos decorativos (armadura y escalera monumental, como elementos mudéjares a destacar), descripción exterior e interior de la Iglesia antes de dicha Guerra, armaduras de la nave, cúpula de la capilla mayor. También nos remite a otros documentos que hemos utilizado como fuente para nuestro estudio. Estos datos aparecen en:

- $\quad$ LÓPEZ FERNÁNDEZ, Domingo A․ "Los Mínimos de San Francisco de Paula. Precedentes y fundación del Convento de la Victoria en la Villa de Motril.” En: SÁNCHEZ RAMOS, Valeriano (Coord.) Los Mínimos en Andalucía. IV Centenario de la fundación del Convento de Nuestra Señora de la Victoria de Vera (Almería). Almería: Instituto de Estudios Almerienses, Ayuntamiento de Vera y Orden Mínima. 2006. págs. 187-237.

${ }^{16}$ Nos describe secuencialmente las iglesias de Sorvilán, Polopos, Gualchos, Lújar, la Iglesia Mayor Parroquial de la Encarnación, Salobreña, Lobres y Lentegí. En estas descripciones nos hace una introducción histórica donde nos aporta fechas de construcción y nombre de constructores, además de otros datos, como saqueos, edificaciones posteriores, para pasar a describirla en su estado actual con su orientación, nave, planta, muros, torre. Estos datos aparecen en:

- MARTÍN GARCÍA, Mariano. "Iglesias Fortificadas de la costa granadina”. En: Actas del IV Congreso de Castellología. Madrid: Asociación Española de los Amigos de los Castillos, 2012. págs. 713-734. 
1. Acercarnos a la realidad social y política de la costa de Granada durante el periodo mudéjar y morisco.

2. Analizar científicamente las iglesias mudéjares de la costa de la provincia de Granada.

3. Estudiar las transformaciones sufridas en dichas iglesias, definiendo lo original y las adicciones de otras épocas.

4. Describir la arquitectura actual, siempre con las referencias históricas necesarias.

5. Valorar el patrimonio mudéjar de la costa de Granada.

\section{Metodología y proceso de investigación.}

La metodología utilizada para la realización del Trabajo Final de Máster: "Arquitectura religiosa mudéjar de la Costa de Granada", ha sido bastante amplia. Una vez tuve claro que el objeto de mi estudio iba a ser el Arte Mudéjar en la Costa de la provincia de Granada, lo primero que realicé fue una completa localización de las principales iglesias y templos mudéjares de esta zona a través de alguna documentación. ${ }^{17}$ De esta manera, una vez localizadas estas iglesias, lo siguiente fue la situación geográfica de las poblaciones donde se ubicaban dichos templos, de esta manera utilicé el Google Maps para tal fin para saber las zonas de la Costa de Granada en las que se encontraban estas poblaciones. ${ }^{18}$ A continuación utilicé dos documentos de Antonio Malpica Cuello ${ }^{19}$ en el que nos describe geográficamente la Costa de Granada en cada una de sus partes dentro de la Historia de Época Islámica la Costa de Granada y nos localiza cada población.

Una vez configurada la parte geográfica, pasé a elaborar la realidad social y política de los mudéjares y moriscos a finales del s. XV y principios del s. XVI de la Lara. 2006.

${ }^{17}$ VV.AA. Guía artística de Granada y su provincia, Vol. II. Granada: Fundación José Manuel

${ }^{18}$ Lentegí, Otívar, Jete, Salobreña, Lobres, Los Guájares, Motril, Lújar, Gualchos, Rubite, Polopos, Sorvilán, Albondón.

19 - MALPICA CUELLO, Antonio. La Costa de Granada en Época Medieval. Poblamiento y territorio. Motril: Ayuntamiento de Motril, 1994.

- MALPICA CUELLO, Antonio. Las últimas tierras de Al-Ándalus. Paisaje y poblamiento del reino nazarí de Granada. Granada: Universidad de Granada, Consorcio para la Conmemoración de la Fundación del Primer Milenio del Reino de Granada, 2014. 
Costa de Granada, utilizando bibliografía de diferentes fondos bibliotecarios tanto de la Biblioteca de la Universidad de Granada como de la Red de Bibliotecas Públicas de Motril y digitales. Para esta parte lo hice así porque tenía claro que había que hacer un análisis de la situación de los musulmanes en su estatus de mudéjares y moriscos bajo el orden Castellano en la zona de la Costa ya que es básico saber los cimientos sobre los que se asienta este arte y estas iglesias que estoy analizando en el trabajo. Pero no solo recabé fondos bibliográficos para la parte histórica, sino que también me hice con fondos bibliográficos sobre teoría del arte mudéjar en el Reino de Granada para estudiar las formas de este arte en dicha zona y en sus diferentes partes geográficas, y los diferentes componentes que forman parte de este como pueden ser las armaduras, los tipos de arcos, los tipos de plantas de iglesias, el alfiz, los enlucidos de las fachadas, etc. Pero también, me hice con bibliografía específica que tratara directamente el objeto de mi estudio tanto para ver la información que había sobre ellas, como para extraer la misma información, como fechas de construcción, nombres de constructores, reconstrucciones, etc.

Partiendo de este estudio bibliográfico, en diciembre de 2018 empecé a realizar el trabajo de campo y a la visita "in situ" de cada uno de los templos e iglesias que había localizado. En este análisis, antes de realizar dicha visita, me ponía en contacto con el sacerdote que rige la iglesia para pedir los permisos oportunos para realizar el análisis y las fotografías y para saber el horario de apertura del templo, algo que se me ofreció sin ningún tipo de impedimento. Hay que decir que, en el caso de Motril, en ninguno de los tres templos analizados no tuve que pedir permiso ya que suelen estar abiertos en horarios amplios. El trabajo que realizaba en esas visitas es el siguiente: En primer lugar, hacia un visionado general del exterior, y posteriormente de cada una de las partes individualmente (fachada principal, laterales, fachada norte, etc.) y pasaba a realizar las fotos de cada una de esas partes. A continuación, pasaba al interior, y una vez que, hacia una vista rápida, analizaba cada parte (planta, cubiertas, naves, capilla mayor, armadura, canes, tirantes, cuadrales, bóvedas, arcos, alfarje...) y después el posterior fotografiado de cada una de las partes y elementos significativos. En tercer lugar, preguntaba a los feligreses de la parroquia y a los vecinos del pueblo como estaba la iglesia antes y después de la Guerra Civil y como recuerdan la iglesia en años anteriores y sus modificaciones y adicciones. Y, por último, ya en casa, analizo todos los datos recogidos de los testimonios vecinales y de las fotografías y de las notas que 
haya tomado. El orden de visita de las iglesias se ha de indicar que no ha sido el orden en el que están situadas en el trabajo ya que en este siguen a la descripción geográfica, yo las he visitado por disponibilidad horaria y cercanía al lugar. De esta manera, empecé por las iglesias de Motril: Iglesia Mayor Parroquial de la Encarnación, la Iglesia de la Victoria y la Iglesia de la Divina Pastora, esto fue en el mes de diciembre. En Enero, visité en primer lugar, Lújar y Gualchos en el mismo día, y a la semana, Albondón y Rubite. En febrero solo pude visitar Polopos y Sorvilán; en Marzo he visitado Salobreña, Lobres, Jete, Lentegí y Otívar; y por último las tres parroquias de Los Guájares (Guájar Fondón, Guájar Faragüit y Guájar Alto).

Una vez recogida y recopilada toda la información de cada iglesia procedí a realizar el comentario propio de cada una de ellas, el cual nos servimos de la estructura de un comentario arquitectónico en el que analizaba todas y cada una de las partes de un edificio (planta, muros, cubiertas, vanos, estructura, exterior, interior, fachadas,...) a partir del cual confeccionamos nuestro propio esquema de comentario que fue el siguiente: Introducción histórica y análisis de los materiales constructivos; tipo de planta con sus naves, capilla mayor y sus diferentes dependencias; exterior: con una descripción detallada de todas sus fachadas y sus portadas, de todos sus lados, junto con el carácter mudéjar que dicha fachada tiene o ha podido tener, además de los vanos; interior: describiendo los muros, como se cubre cada una de las partes de la iglesia (nave, coro, capilla mayor), como son los detalles de esas cubierta (tipo de armadura, alfarje, bóvedas); y por último, una descripción detallada de la torre de la iglesia, situándola. Eso sí, hemos de indicar, que este esquema ha variado en algunas iglesias dependiendo de sus características. En estos comentario he ido intercalando algunas de las fotografías por mí en el trabajo de campo acordes con lo que se va describiendo en cada párrafo, aportado el siguiente tipo de fotografías: Vista general de la iglesia; de la planta, el plano de la iglesia (si lo he encontrado), las naves laterales, la capilla mayor, el arco toral, el coro, y algunos elementos estructurales; del exterior: la fachada principal, los laterales, la portada o portadas; del interior, las armaduras, bóvedas, alfarje, cubiertas, con sus diferentes detalles; y de la torre y su situación en la iglesia. De estas fotografías he aportado un listado de estas donde se pueden observar individualmente.

Hay que indicar que conforme iba acabando el trabajo de campo de visitar a las iglesias y su posterior comentario, fui elaborando la introducción, la 
metodología, las conclusiones, la bibliografía, el resumen y los agradecimientos. Para realizar la instrucción, en las que se me piden unos antecedentes sobre el estudio que he realizado, he incluido información de los principales historiadores e historiadores del arte que han trabajado sobre el Reino de Granada y sobre el Arte de la Provincia de Granada que tratan directa o indirectamente el objeto de mi estudio, además de los principales objetivos de mi trabajo de investigación. En la metodología, he informado de todo el proceso de elaboración del trabajo paso a paso. En las conclusiones he recogido los resultados que he recabado del trabajo; en el resumen hago una breve reseña de lo que se trata el trabajo y en los agradecimientos trato de mencionar a las personas que de una manera u otra han contribuido al desarrollo del proceso de investigación.

El esquema que he seguido en el trabajo no es el esquema de estudio como se ve claramente, ya que primeramente en el trabajo que puesto la parte histórica pretendiendo situar en el contexto social y político a la zona de la Costa de Granada en la época mudéjar y primera etapa morisca, para que después se pueda hablar de la geografía de dicho territorio situando a las diferentes poblaciones donde se encuentran las iglesias de nuestro ámbito, siendo éstas el siguiente punto. El orden que el comentario de las iglesias sigue es el orden en el que aparecen citados sus poblaciones en la parte geográfica: Lentegí, Otívar, Jete, Salobreña, Lobres, Los Guájares, Motril, Lújar, Gualchos, Rubite, Polopos, Sorvilán y Albondón.

\section{Introducción histórica.}

\section{Capitulaciones de rendición.}

El reino nazarí de Granada fue un reino bastante próspero en muchos sentidos, pero como era de suponer, sufrió las incursiones del Reino de Castilla durante el siglo $\mathrm{XV}$, especialmente a finales de dicho siglo.

Así lo confirman las actas documentales de los diferentes archivos y las actas capitulares en la que se reflejan los acuerdos de rendición de los musulmanes nazaríes ante sus nuevos gobernantes cristianos, para no seguir con una guerra de desgaste por ambas partes que los estaba socavando.

De esta manera, el estudio de dichas Capitulaciones es el marco de referencia para explicar los diversos aspectos de los mudéjares granadinos. 
Pero, antes de nada, hemos de explicar en qué consistían dichas Actas. Estas capitulaciones eran una tradición jurídica para la incorporación de los musulmanes peninsulares a la jurisdicción de los reinos cristianos, y se llevaron a cabo en todo el territorio peninsular. Además, fueron la mejor solución como instrumento político de sometimiento de una inmensa población y para poner fin a una guerra, pero no solo eso, sino que se aseguraban unos puntos de actuación sobre los que actuar en medio de dicha población de mayoría musulmana sobre la que saber cómo actuar.

Ahora, bien es verdad, que una cosa es lo que se firma y otra es lo que se pone en práctica, porque a comienzos del s. XVI, con las conversiones forzosas auspiciadas por el Cardenal Cisneros y con el beneplácito de la Corona, que se llevaron a cabo en todo el Reino de Granada, se incumplieron estas capitulaciones. ${ }^{20}$

Pero estas Capitulaciones se fueron escalonando en todo este extenso territorio, según nos informa D. Miguel Ángel Ladero Quesada, estableciendo tres periodos:

$1^{\circ}$. De 1484 a 1487, las capitulaciones del Obispado de Málaga.

$2^{\circ}$. De 1488 a 1489, las capitulaciones de la Costa de Granada, Almería, Baza y Guadix.

$3^{\circ}$. La de 1492, la Capitulación de la Ciudad de Granada, la Vega, y las Alpujarras.

A nosotros, por nuestro estudio, nos afecta la del segundo periodo, es decir las Capitulaciones de la Costa de Granada. Y en ellas, los castellanos han aumentado las concesiones a la comunidad musulmana vencida con respecto a las del Obispado de Málaga, así se les respeto sus costumbres que estaban en boga desde época musulmana; se les respeto la libertad religiosa individual; aparece las primeras alusiones a una “justicia mudéjar”, además se imponen los perdones generales y la comunidad musulmana se ve libre de responsabilidad colectiva por faltas cometidas por individuos particulares.

De esta manera, se puede decir, que estas capitulaciones, son un antes y un después para ambas comunidades por las condiciones que contenían ya que antes no se

${ }^{20}$ GALÁN SÁNCHEZ, Ángel. Los mudéjares del Reino de Granada. Granada: Universidad de Granada, Diputación Provincial de Granada. 1991. págs. 74-94, 81-105. 
habían contenido, pero eran la única vía para acabar pronto con la guerra, algo que ambas partes deseaban.

Aunque hemos de determinar, que, aunque esto se firmara, la realidad fue bien distinta, sí, los musulmanes pasaron al régimen y estatuto mudéjar, pero estas concesiones no se plasmaron en la vida, sino que se ajustaron parcialmente, haciendo que a lo largo de la década que lleva hasta las conversiones forzosas se hicieran nuevas capitulaciones y tratados, para modificar los pactos según los intereses de cada momento, tanto de una comunidad como de otra. ${ }^{21}$

En cuanto a la división administrativa tras esta conquista, todo el reino de Granada, y con él la Costa granadina, a la llegada de los cristianos, estaba formada en su mayor parte por alquerías; "comunidad rural de base, que agrupaba una serie de casa que explotaba unos terrenos colindantes, con o sin dependencia social y económica de una medina, dependiendo de cada caso" 22 , comprendiendo las medinas un número mucho menor, y que se convirtieron en la principal herramienta de ordenación del territorio tras la conquista, ${ }^{23}$ siendo las cabezas de dichas alquerías, en las que se distribuían alrededor de 170000 mudéjares, de los cuales, 10000 pertenecerían a las morerías de Baza, Guadix, Almería, Motril y Málaga. ${ }^{24}$

Los Reyes Católicos para controlar todo este inmenso territorio idearon todo el sistema de repoblación, ${ }^{25}$ aunque siguiendo todo lo establecido por lo firmado en las capitulaciones, como hemos visto; además de establecer toda una estructura jurídica que se basaba en tres ámbitos: la procedente del antiguo reino nazarí, la importada por los propios cristianos, y la que se creó para la población mudéjar, representando los tres una misma institución y englobados bajo el mismo sistema.

${ }^{21}$ Ibídem., págs. 81-105.

22 Ibíd., págs. 79-82.

${ }^{23}$ RUÍZ POVEDANO, José María. "Las ciudades y el poder municipal”. En: PEINADO SANTAELLA, Rafael G. (Coord.). Historia del Reino de Granada I: De los orígenes a la época mudéjar (hasta 1530). Granada: Editorial Universidad de Granada. 2000, págs. 611-660, págs. 611-618.

24 GALÁN SÁNCHEZ, Ángel. Los mudéjares del Reino.... Op. cit., págs. 24-38.

${ }^{25}$ PEINADO SANTAELLA, Rafael G. "La sociedad repobladora: el control y la distribución del espacio". En: PEINADO SANTAELLA, Rafael G. (Coord.). Historia del Reino de Granada I: De los orígenes a la época mudéjar (hasta 1530). Granada: Editorial Universidad de Granada, El Legado Andalusí. 2000, págs. 477- 524, pág. 477. 
Pero, esta estructura dio lugar a toda una división entre la propia población musulmana y la cristiana, pero también en las mismas comunidades internamente. Todo un sistema que justifica la injerencia cristiana y su imposición a los musulmanes y la convivencia junto a la división social musulmana y de representación que estos tenían, justificando la recogida de impuesto que hereda prácticamente de la antigua estructura, como veremos más adelante.

También, hemos de indicar que tanto los mudéjares como los moriscos (tras las conversiones) gozaron de autogobierno, aunque seguían existiendo las antiguas oligarquías nobiliarias y el sistema tradicional de gobierno. ${ }^{26}$

De esta manera, los representantes de estas comunidades en las zonas rurales, como es el caso de la Costa de Granada, recaían en las familias nobles nazaríes que no huyeron y que empezaron a asumir estas funciones de representación, desplazando a los alguaciles o alfaquíes de la antigua estructura, aunque estos último seguían teniendo poder como notarios y administradores de la justicia, además de ser grandes influyentes en la comunidad. ${ }^{27}$

Tanto estas familias nobles y oligárquicas, como los alguaciles y alfaquíes era los principales colaboradores de los dirigentes y Reyes Castellanos y contribuían a la recogida de impuestos, a imponer la justicia, a administrarla, a imponer leyes, y todo a cambio de dotes, bienes, economía, política, social e influencia en medio de la comunidad mudéjar. ${ }^{28}$

Pero los mudéjares colaboracionistas se pueden dividir en tres grupos:

$1^{\circ}$. Los que son llamados para resolver los problemas que afectan a toda la comunidad mudéjar general o a grupos numerosos; constituyendo este grupo un número reducido de personas, entre los que se encuentran, dos alfaquíes, Yuçaf el Mudéjar y Mahomad el Pequeñi, tres comerciantes, Yuça de Mora, Mahomad el Dordux y Yaya el Fistelí; y dos personajes de la zona oriental del reino; los hermanos Abduladín. Estos forman la cúpula de colaboracionistas, pero no son los únicos.

\footnotetext{
${ }^{26}$ GALÁN SÁNCHEZ, Ángel. Los mudéjares del Reino.... Op. cit., págs. 249-250.

${ }^{27}$ Ibídem, págs. 283-288.

${ }^{28}$ Ibíd., págs. 260-276.
} 
$2^{\circ}$ Después están los poderes intermedios, formados por los que ya hemos nombrado, es decir, los alguaciles y alfaquíes, presentes en las pequeñas comunidades rurales. Estos transmiten los planes de la corona, cumpliendo las funciones de gobierno local y de recaudador de impuestos y tenían sus ventajas, como hemos visto.

Elegidos según la adhesión ante los nuevos poderes, procurando elegirlos entre los más ricos del lugar, en cuanto a los alguaciles.

Con respecto a los alfaquíes, la Corona quería tener cierto control sobre ellos a cambio favores, y mientras existió la justicia mudéjar eran los encargados de administrarla.

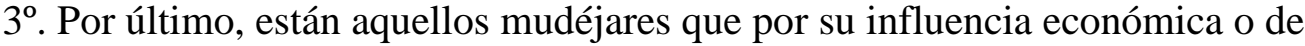
otro tipo, reciben un trato especial por parte de la Corona. ${ }^{29}$

\section{Conflictividad entre comunidades.}

A pesar de todo el colaboracionismo, de las capitulaciones, de todo el entramado construido por los Reyes Católicos y las prebendas de unos y otros, hubo numerosos conflictos que hicieron saltar la chispa de ataques de ambas comunidades.

Tanto es así, que hasta los mismos Reyes impusieron leyes en la Costa impidiendo a los mudéjares vivir cerca del litoral, moverse sin declarar su procedencia, les obligaron a pagar la farda costera (impuesto para la defensa de la costa ante los ataques de los piratas que ellos mismo ayudaban), obligación de aportar guardas para dicha defensa, y todo porque los mismo mudéjares respondieron a los ataques de los cristianos ayudando a los piratas que venían del Norte de África y el bandolerismo interno.

Con respecto a los ataques de los cristianos, estos se basaron en las confiscaciones de tierra, en la esclavitud de personas y robos. Aunque hemos de suponer que no todo estaría provocado por los propios cristianos, ya que los mudéjares estarían muy conectados ideológica y religiosamente con las actuaciones de los piratas africanos.

${ }^{29}$ GALÁN SÁNCHEZ, Ángel. Una sociedad en transición: los granadinos de mudéjares a moriscos. Granada: Universidad de Granada. 2010, págs. 105-109. 
Así, al colaborar con dichos piratas, secuestraban a cristianos para luego pedir rescates, pero además confiscaban mercancías que iban dirigidas a puertos, e informaban a los enemigos de los castellanos las posiciones defensivas, y les daban apoyo logístico.

Todo esto hizo que la conflictividad fuera algo normal en la vida de la costa y que la convivencia fuera algo complicada, aunque fue por momentos. ${ }^{30}$

Aunque otro de los factores de la ruptura de la convivencia es la no puesta en práctica por parte de los castellanos de lo acordado en las capitulaciones. ${ }^{31}$

En el terreno de la recaudación de impuesto en el nuevo orden que se establece tras la conquista, se ha de decir que se continúa con el sistema anterior de época nazarí, aunque se establecieron otro nuevos como el pagar los rescates de los secuestros perpetrados por los mudéjares y piratas, pagar la farda costera, los daños sufridos por los piratas y por las propias sublevaciones de sus conciudadanos en las tierras costeras, ${ }^{32}$ impuestos extraordinarios que el mismo sistema nazarí ya justificaba. ${ }^{33}$

Pero, para que la recaudación de estos impuestos fuera un éxito, tenía que haber todo un entramado de colaboradores mudéjares, como hemos podido ver antes, que ayudaran en esta ardua y conflictiva labor, ya que generaban rivalidad e ira entre la población musulmana. ${ }^{34}$

\section{Conversiones al Cristianismo forzosas.}

A finales del s. XV, en torno a 1499, los mudéjares empezaron a sufrir las consecuencias de la política planeada e ideada por los Reinos Cristianos de la Península y por la Iglesia Católica desde el comienzo de la Conquista, y es la de la Unidad Religiosa en todo el territorio, auspiciada por el contexto socio-político que se estaba dando en todo el continente europeo de unidad confesional dentro de la comunidad

${ }^{30}$ GALÁN SÁNCHEZ, Ángel. Los mudéjares del Reino.... Op. cit., págs. 293-354.

${ }^{31}$ MONTES ROMERO-CAMACHO, Isabel. "Las comunidades mudéjares en la corona de Castilla durante el s. XV”. En: VIII Simposio Internacional de Mudejarismo, De mudéjares a moriscos: una conversión forzada. Teruel: Centro de Estudios Mudéjares, 1999, págs. 367-480, págs. 417-433.

${ }^{32}$ LÓPEZ DE COCA CASTAÑEZ, José Enrique. "La fiscalidad mudéjar en el reino de Granada". En: V Simposio Internacional de Mudejarismo. Teruel: Instituto de Estudios Turolenses, 1991, págs. 191-220. págs. 206-213.

${ }^{33}$ GALÁN SÁNCHEZ, Ángel. Los mudéjares del Reino.... Op. cit., págs. 105-126. págs. 198-206.

${ }^{34}$ LÓPEZ DE COCA CASTAÑEZ, José Enrique. "La fiscalidad mudéjar en el reino.... Op. cit., 
estatal, unidad monárquica y rápida conversión para la salvación de las almas, además de controlar mejor a la población. ${ }^{35}$

Esto propició que la Iglesia, encabezada por el Cardenal Cisneros, comenzara una investigación de los elches, "cristianos convertidos a la religión islámica”, para provocar su vuelta a la Fe cristiana, algo que provocó el levantamiento de los mudéjares del Albayzín granadino, además de la ruptura de las capitulaciones, aunque estas conversiones no eran forzadas ni eran destinadas en un primer momento para las masas sino para individuos, como si lo fueron las de $1500 .{ }^{36}$

Ante este levantamiento, los Reyes actuaron y se propició, la conversión en masa, algo insólito y que no compartían otros sectores eclesiales, entre los que se encontraba el arzobispo de Granada Fray Hernando de Talavera, el cual era más partidario de la persuasión que de la imposición. ${ }^{37}$ Pero no solo él, sino que gran parte de la Iglesia pesaba igual, ya que las conversiones forzosas no estaban establecidas en los decretos, y se pensaba que fueron apresuradas, fracasadas y se "creyó" con facilidad en la conversión de los que se bautizaban con su supuesta "voluntad". 38

Por estas conversiones forzosas, los alguaciles, representantes de la comunidad musulmana, y con ellos toda la población islámica, se dirigen a los Monarcas cristianos para llegar a un acuerdo y ofrecer un pacto que les conduzca a una conversión "voluntaria” al Cristianismo.

Los Reyes Católicos aceptan estos pactos y elaboran diferentes capitulaciones de conversión, dependiendo del lugar y situación de cada población, pero que todas tenían en común una serie de directrices generales, algunas de las cuales citamos a continuación, como que, los moriscos:

1. Estarán exentos de derechos y pechas del fisco mudéjar.

2. Pagarán los impuestos como todos los cristianos.

63.

${ }^{35}$ GALÁN SÁNCHEZ, Ángel. Una sociedad en transición: los granadinos.... Op. cit., págs. 49-

${ }^{36}$ LADERO QUESADA, Miguel Ángel. "Los Bautismos de los musulmanes granadinos en 1500". En: VIII Simposio Internacional de Mudejarismo, De mudéjares a moriscos: una conversión forzada. Teruel: Centro de Estudios Mudéjares, 1999, págs. 481-542, págs. 481-496.

${ }^{37}$ GALÁN SÁNCHEZ, Ángel. Los mudéjares del Reino.... Op. cit., págs. 357-361.

${ }^{38}$ GALÁN SÁNCHEZ, Ángel. Una sociedad en transición: los granadinos.... Op. cit., págs. 49. 63-74. 
3. Desaparecerá todo lo relativo a la justicia mudéjar y en adelante serán juzgados como todos los cristianos.

4. Sus contratos en lengua árabe gozarán de la misma validez que si los hubiesen otorgado ante un escribano público cristiano.

5. Se les concede un perdón general de culpas por delitos cometido hasta el momento de la conversión.

6. Tendrán clérigos y sacristanes que les adoctrine en la Fe Católica.

7. Mantendrán sus carniceros y pescadores, aunque estarán obligados a matar las carnes como cristianos viejos. ${ }^{39}$

Así, los musulmanes, tras estas conversiones pasaron a ser denominados moriscos o cristianos nuevos, con una clara diferencia de aquellos cristianos que lo eran desde varias generaciones anteriores, además de que estos últimos establecieron a su vez diferencias con sus nuevos correligiosos por las siguientes razones:

$1^{\circ}$ Por diferencia religiosa, considerándolos apóstatas y renegados que habían recibido el bautismo y que eran muy dados a la magia y hechicería.

$2^{\circ}$ Por diferencia de idioma, considerando que hablan otro idioma y otro tipo de romance.

$3^{\circ}$ Por diferencia de usos y costumbres en el modo de vivir: en el vestir, la alimentación, la higiene, las fiestas y ritos, y la vida familiar.

$4^{\circ}$ Por diferencias físicas y temperamentales: color, pelo gestos y por ser más sobrios al comer o más lujuriosos y fecundo. ${ }^{40}$

Pero, como en la sociedad mudéjar, también entre la población morisca, hay una estratificación social, dependiendo de la riqueza y de los cargos que se ocupan y del orden de colaboración que se sigue ejerciendo con respecto a la Corona.

Así, nos encontramos en los más bajo, con los "gacis" que eran los moros africanos, esclavos o cautivos liberados, que se establecieron en el sur después de la Conquista. Éstos después de la Guerra de 1568 tenían grandes familias y formaban linajes diferenciados.

\footnotetext{
${ }^{39}$ Ibídem., págs. 75-79.

${ }^{40}$ CARO BAROJA, Julio. Los Moriscos del reino de Granada. Madrid: Ediciones Itsmo, S.A., 1991.págs. 48-63.
} 
A continuación, hemos de mencionar a los "mudéjares antiguos" que recibieron un trato más benevolente.

Los que tuvieron más animadversión fueron los “elches".

Después están los "tagarinos" que son aquellos musulmanes llegados de Aragón y la meseta muy cristianizados para ser ejemplo de sus conciudadanos. ${ }^{41}$

Pero también hemos de distinguir una división según la riqueza y el poder que ostentaban según la colaboración.

De esta manera, entre los más poderosos se encontraban las familias ennoblecidas, que procedían del antiguo reino nazarí, y que habían permanecido durante la etapa mudéjar y ahora continúan bajo el favor de la Corona por el colaboracionismo.

En el grupo intermedio están los colaboracionistas a nivel local, regidores moriscos, alguaciles y otros cargos que se supeditan a la Corona a cambio de mercedes, como hemos podido ver en el periodo mudéjar.

En otro nivel se encuentran los comerciantes moriscos, el sistema de funcionarios, profesionales liberales, acomodados propietarios rurales.

Y en la parte más baja, la inmensa mayoría de los moriscos de clase baja. ${ }^{42}$

Este periodo morisco es un momento de confrontación entre los denominados cristianos viejos (castellanos) y cristianos nuevos (moriscos) debido a toda la carga ideológica que se proyecta sobre estos moriscos por parte de la Corona y de la Iglesia para su proceso de cristianización y conversión de sus antiguas formas de vida islámicas. Estos conflictos acabarán estallando en la denominada Guerra de las Alpujarras que sucedió entre 1568 y 1572, alzamiento morisco que también afecto a la Costa de Granada. Estos conflictos se pusieron fin de forma drástica con la posterior

${ }^{41}$ Ibídem, págs. 91-97.

${ }^{42}$ CASTILLO FERNÁNDEZ, Javier. "Las estructuras sociales". En: BARRIOS AGUILERA, Manuel (Coord.). Historia del Reino de Granada II. La época morisca y la repoblación (1502-1630). Granada: Editorial Universidad de Granada, El Legado Andalusí. 2000. Págs. 179-230, págs. 178-204. 
expulsión definitiva de los moriscos entre 1609 y $1614^{43}$, provocando la despoblación de gran parte del antiguo Reino de Granada ${ }^{44}$ incluyendo la Costa.

\section{Medio físico y geografía histórica.}

Geográficamente, la Costa granadina es aquella ladera formada por una cordillera compuesta por las Sierras de Tejeda, Almijara, Lújar y Contraviesa, en la que las altas cumbres están bastante cerca del mar, haciendo que la pendiente sea muy constante, formándose barrancos y torrentes, aunque el único río importante de la zona es el río Guadalfeo que nace en Sierra Nevada. ${ }^{45}$

Pero antes de empezar a analizar el territorio costero en este aspecto, hemos de decir, está dividido en tres zonas históricas, cuya estructuración procede ya desde la etapa nazarí y que se sigue respetando actualmente.

Estas zonas son las denominadas, Almuñécar y su territorio; Salobreña-Motril y el conjunto de su distrito, y la Tahá de los Céjeles, o como se le conoce hoy, Área alpujarreña costera. ${ }^{46}$

Cada una tiene de dichas zonas tiene sus peculiaridades y particularidades topográficas y físico-geográficas, que hacen que las distintas poblaciones tengan a su vez diferentes características, estando situadas en la misma zona costera.

En primer lugar, nos encontramos con Almuñécar y su territorio, que comienza en La Herradura y llega hasta Salobreña, recorriendo la costa, que pasa por numerosos acantilados y escasas calas, con crestas montañosas elevadas muy cerca del mar, y se rompe con un sistema de ríos, barrancos y torrentes. A ella se llega por un camino tortuoso y con dificultades, el cual se adentra en la ciudad de Almuñécar ya desde época fenicia. $^{47}$

${ }^{43}$ LÓPEZ GUZMÁN, Rafael. Arquitectura Mudéjar. Madrid: Ediciones Cátedra (Grupo Anaya, S.A.), 2000., pág. 387.

${ }^{44}$ Ibídem., pág., 400.

${ }^{45}$ MALPICA CUELLO, Antonio. La Costa de Granada en Época Medieval. Poblamiento y territorio. Motril: Ayuntamiento de Motril, 1994, pág. 248.

46 Ibídem, págs. 248-261.

${ }^{47}$ MALPICA CUELLO, Antonio. Las últimas tierras de Al-Ándalus. Paisaje y poblamiento del reino nazarí de Granada. Granada: Universidad de Granada, Consorcio para la Conmemoración de la Fundación del Primer Milenio del Reino de Granada, 2014., págs. 643-659. 
El territorio se encuentra en la parte sur de las Sierras de Tejeda y Almijara, cordilleras alpinas que chocan con el mar; y el principal río articulador es el denominado con el nombre "Verde" alrededor del cual se articulan diferentes alquerías y poblaciones, en su margen derecho e izquierdo. Así, descendiendo desde su nacimiento nos encontramos con Cázulas, situada al SO de Lentegí, pueblo que hayamos un poco alejado del curso del río, y frente a él, Turillas; en la parte izquierda y colgada sobre el río "Verde", la población de Otívar; y bajando aún más, a su vez en el margen izquierdo, Jete. ${ }^{48}$

La ciudad del Almuñécar en tiempos nazaríes era un importante centro económico y administrativo de toda esta área de población.

La localidad que nos encontramos cuando venimos desde Almuñécar, es Salobreña, que, junto con otras localidades y Motril, forman un conjunto territorial, y en la que ya había yacimientos desde etapas anteriores a la hispanomusulmana, pero el auge lo ganó especialmente durante dicho periodo cuando se construyó su castillo y fue la ciudad de verano de la monarquía nazarí, además aparece en numerosas fuentes andalusíes. Está situada al borde del mar y cerca del río Guadalfeo, al igual que su pedanía de Lobres, antigua alquería de la misma etapa musulmana.

Más arriba, entre las montañas, se encuentran Los Guájares, pasando un enorme desfiladero, y de asentamiento también preislámico, aunque su auge debe situarse en esta etapa histórica. ${ }^{49}$

Motril, ciudad cuyo origen debemos situarlo en la época islámica, entre los siglos XI y XII, estaba muy unido a Salobreña, hasta la conquista por los Reyes Católicos, momento en el cual empieza a cobrar protagonismo y tener un papel primordial en la costa de Granada, debido a las plantaciones de caña de azúcar de su amplia vega y a la actividad mercantil.

Actualmente, Motril es el principal centro de la costa por su recorrido histórico en los siglos posteriores a la conquista cristiana, por la actividad del auge de las plantaciones de la caña de azúcar, que hicieron que la población de la ciudad creciera y

${ }^{48}$ Ibídem. págs. 10-40.

${ }^{49}$ Ibíd., págs. 248-261. 
que la oligarquía y familias adineradas se asentaran en dicha localidad, haciendo de la ciudad un lugar próspero. ${ }^{50}$

La Tahá de los Céjeles o área alpujarreña costera, está compuesta por las antiguas Tahas de Sáhil y Suhayl, cuyo paisaje es áspero y recortado, casi sin calas, y con amplias ramblas en algunas zonas, como la de Albuñol.

Una de las poblaciones de importancia es Castell de Ferro, situada en una cala de la Sierra de Lújar, zona montañosa de la zona que limita con el río Guadalfeo por el oeste y con la Sierra de la Contraviesa por el este.

La Sierra de Lújar no tiene cursos de agua regulares, salvo algunos barrancos o ramblas. Además, en una sierra con una gran masa caliza, y está constituida por materiales de dolomía, y en su interior contiene abundantes mantos de agua que han dado lugar a la existencia de numerosas minas en toda la zona. ${ }^{51}$ (Malpica Cuelo, 1994: 248-261).

En la vertiente sur de la Sierra de Lújar se sitúan la propia localidad de Lújar, Jolúcar, y Gualchos; en el límite entre esta Sierra y la de la Contraviesa, se encuentra Rubite.

En la vertiente sur de La Contraviesa se sitúan Polopos y Sorvilán, en la parte baja de unos barrancos, y en su parte alta, Albondón.

Hemos de decir, que todos estos núcleos poblacionales se han dedicado, desde época islámica hasta la actualidad, a la agricultura, y son áreas rurales de pequeña entidad con un poblamiento establecido desde fechas tempranas, siendo ahora dos núcleos principales de cohesión, Castell de Ferro y Albuñol. ${ }^{52}$

\section{Iglesia mudéjares.}

\subsection{Iglesia Parroquial de San José de Lentegí.}

La Iglesia Parroquial de San José fue construida entre 1543 y 1547 por el albañil Francisco Rodríguez y los carpinteros Juan de Mora y Francisco Ramírez. Hemos de indicar que esta primitiva iglesia fue asolada en el levantamiento morisco de 1568, por

\footnotetext{
${ }^{50}$ Ibíd., págs. 620-641.

${ }^{51}$ Ibíd., págs. 248-261.

52 lbíd., págs. 595-620.
} 
lo que su espacio útil fue considerablemente reducido, convirtiéndose las primitivas naves de la iglesia en cementerio ${ }^{53}$ y el primer tramo de la iglesia se convirtió en un atrio a finales del s. XVI. ${ }^{54}$ Los principales materiales de construcción del templo son la piedra, el ladrillo, el yeso y la madera.

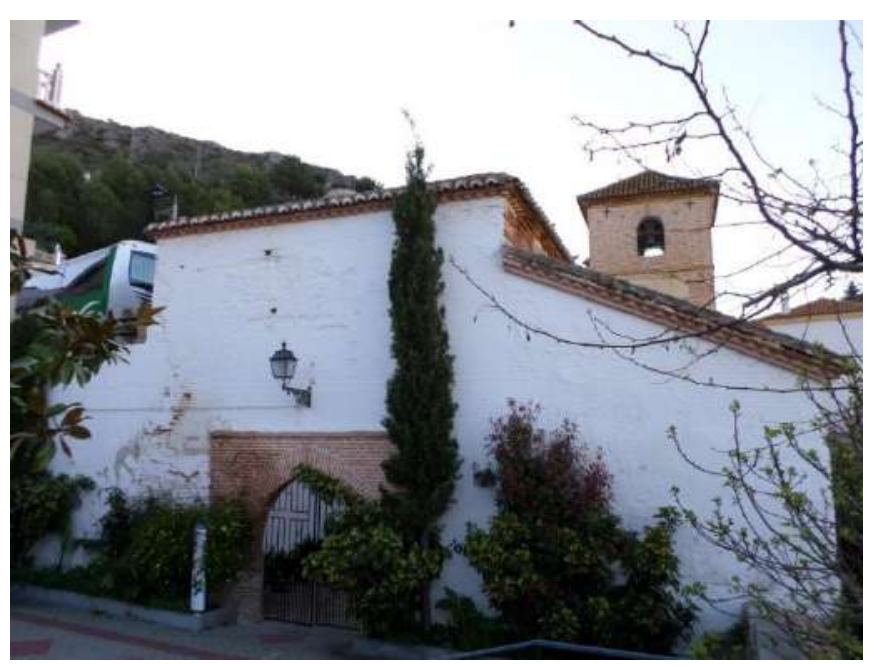

1) Iglesia Parroquial de San José de Lentegí。

De la iglesia que se construyó a finales del s. XVI, después del alzamiento morisco, hemos de decir que presenta una nave única rectangular con capilla mayor a la que se accede por medio de un arco toral ${ }^{55}$ apuntado con listones de madera en las columnas donde se apoya el arco, y con coro a los pies. Accedemos a la sacristía por esta capilla mayor.

\footnotetext{
${ }^{53}$ Cementerio que hasta hace pocos años estuvo allí como nos relatan los vecinos del pueblo.
}

${ }^{54}$ VV.AA. Guía artística de Granada y su provincia, Vol. II. Granada: Fundación José Manuel Lara. 2006, págs. 176.

${ }^{55}$ Este tipo de planta de nave única y capilla mayor cuadrada separada mediante un arco toral responde a las tipologías de planta de iglesias mudéjares de Granada según el estudio realizado por Don Rafael López Guzmán y Don Ignacio Henares Cuéllar en:

- $\quad$ HENARES CUÉLLAR, Ignacio; LÓPEZ GUZMAN, Rafael. Arquitectura Mudéjar Granadina. Granada: Caja de Ahorros y Monte de Piedad de Granada, 1989., págs.. 85-87. 


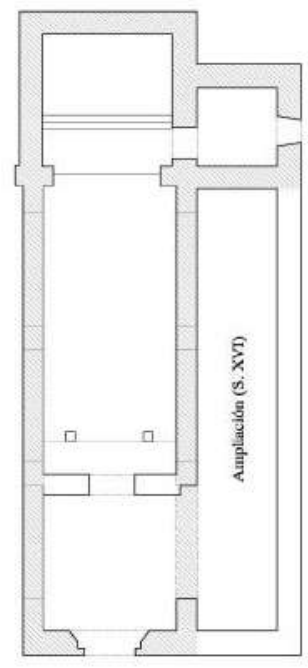

2) Plano de la Iglesia. ${ }^{56}$

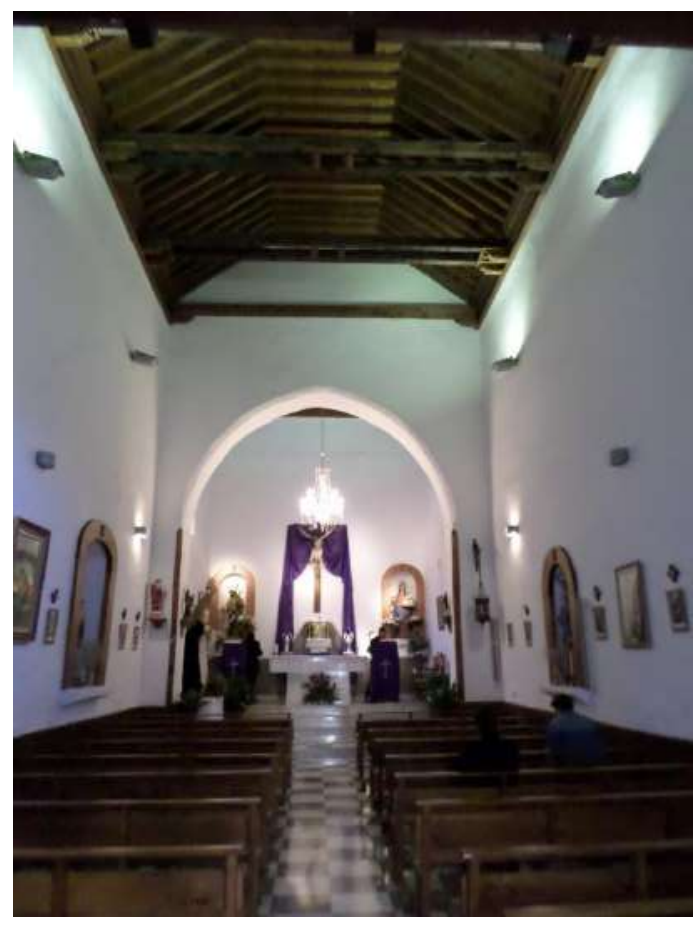

3) Nave de la iglesia.

${ }^{56}$ MARTÍN GARCÍA, Mariano. "Iglesias Fortificadas de la costa granadina”. En: Actas del IV Congreso de Castellología. Madrid: Asociación Española de los Amigos de los Castillos, 2012. págs. 713734. Pág. 734. 


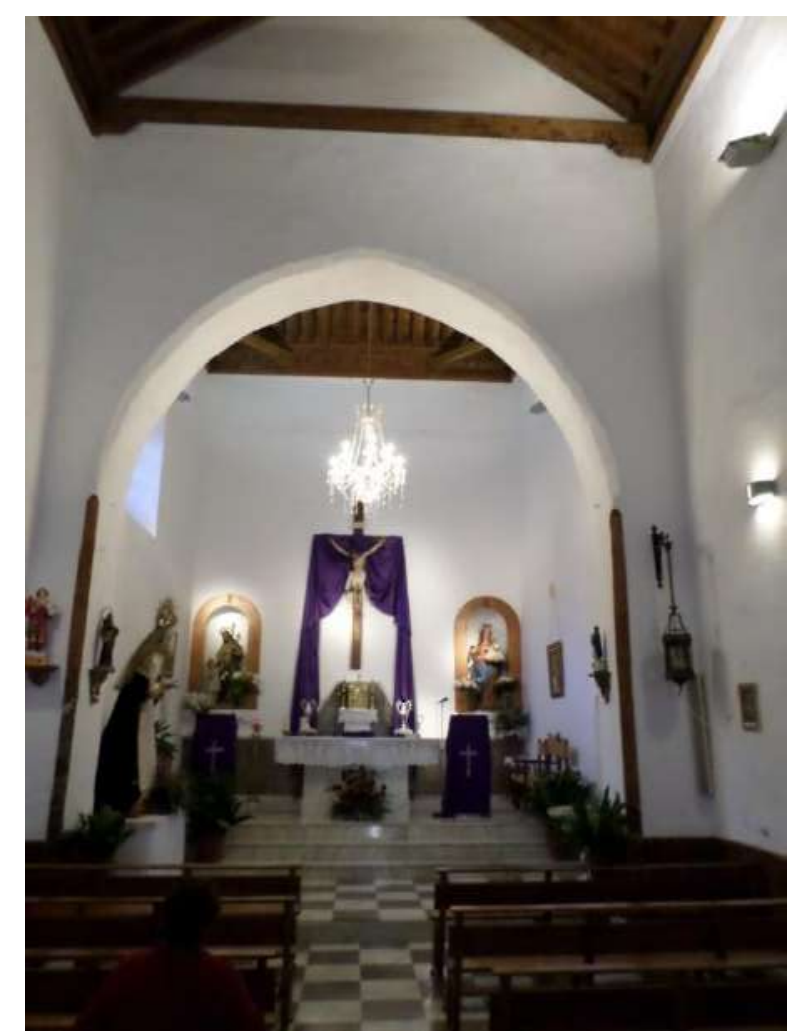

4) Arco toral y capilla mayor.

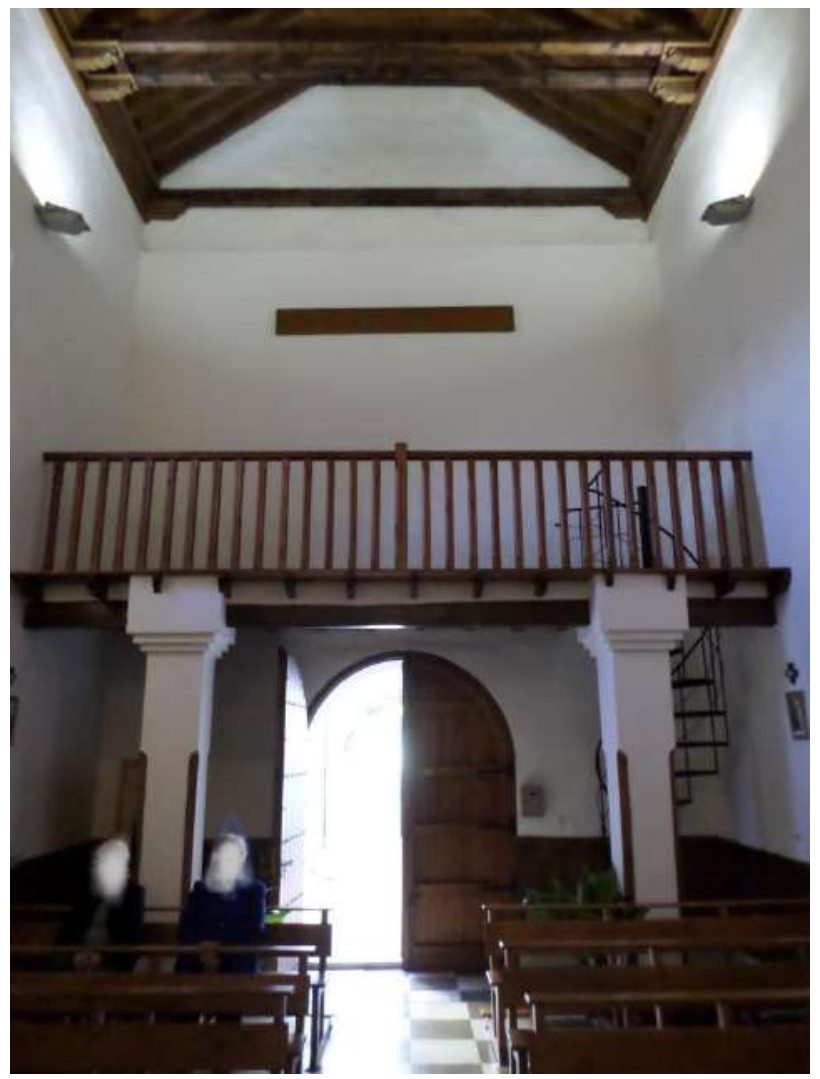

5) Coro. 
En el exterior hemos de describir varios aspectos. En primer lugar hemos de indicar que como obra mudéjar todo el templo está construido en cintas de ladrillo y yeso, aunque tan solo la pared norte, la pared derecha del actual atrio (antigua nave lateral derecha), la torre, la parte superior de la pared derecha de la iglesia actual, la parte superior del atrio (primer tramo de la primitiva iglesia, como hemos indicado al comienzo) y la mitad de la fachada principal, está sin revocar, permitiéndonos apreciar las grandes cintas de ladrillo y yeso y cajones de mampostería. Pero en este exterior también tenemos la fachada de acceso al actual atrio que se corresponde con la fachada principal de primitiva iglesia. Esta fachada está construida en cintas de ladrillo y yeso, pero antes de la Guerra Civil se veían estos materiales como bien nos cuentan los vecinos del pueblo, habiendo perdido el gran esplendor mudéjar que le caracterizaba a la propia fachada. En ella también hay un arco apuntado de ladrillo que enmarca la puerta de acceso rodeado por un alfiz también de ladrillo, algo muy propio de la influencia islámica. A su vez, en esta misma fachada podemos ver como la antigua iglesia destruida tendría tres naves, una principal más alta y dos laterales de menos altura, como vemos en la propia fachada esta disposición. El actual atrio (primer tramo de la antigua iglesia) es un gran cuadrado, donde aparece un predominante arco de medio punto a la derecha que da acceso a la nave lateral derecha de dicha primitiva iglesia hoy convertida en patio y como hemos indicado convertida en antaño en cementerio. Este atrio está revocado hasta la mitad de las paredes permitiendo ver el material de estas. Con respecto a la fachada principal de la actual iglesia, hemos de indicar que es una fachada muy sobria y sencilla, revocada hasta la mitad podemos ver las cintas de ladrillo y yeso y cajones de mampostería en gran parte de ella y en la otra mitad se perciben debajo del revoco. En su puerta de acceso hay un sencillo arco de medio punto de ladrillo sin ningún tipo de decoración, siendo bastante austera dicha fachada. 


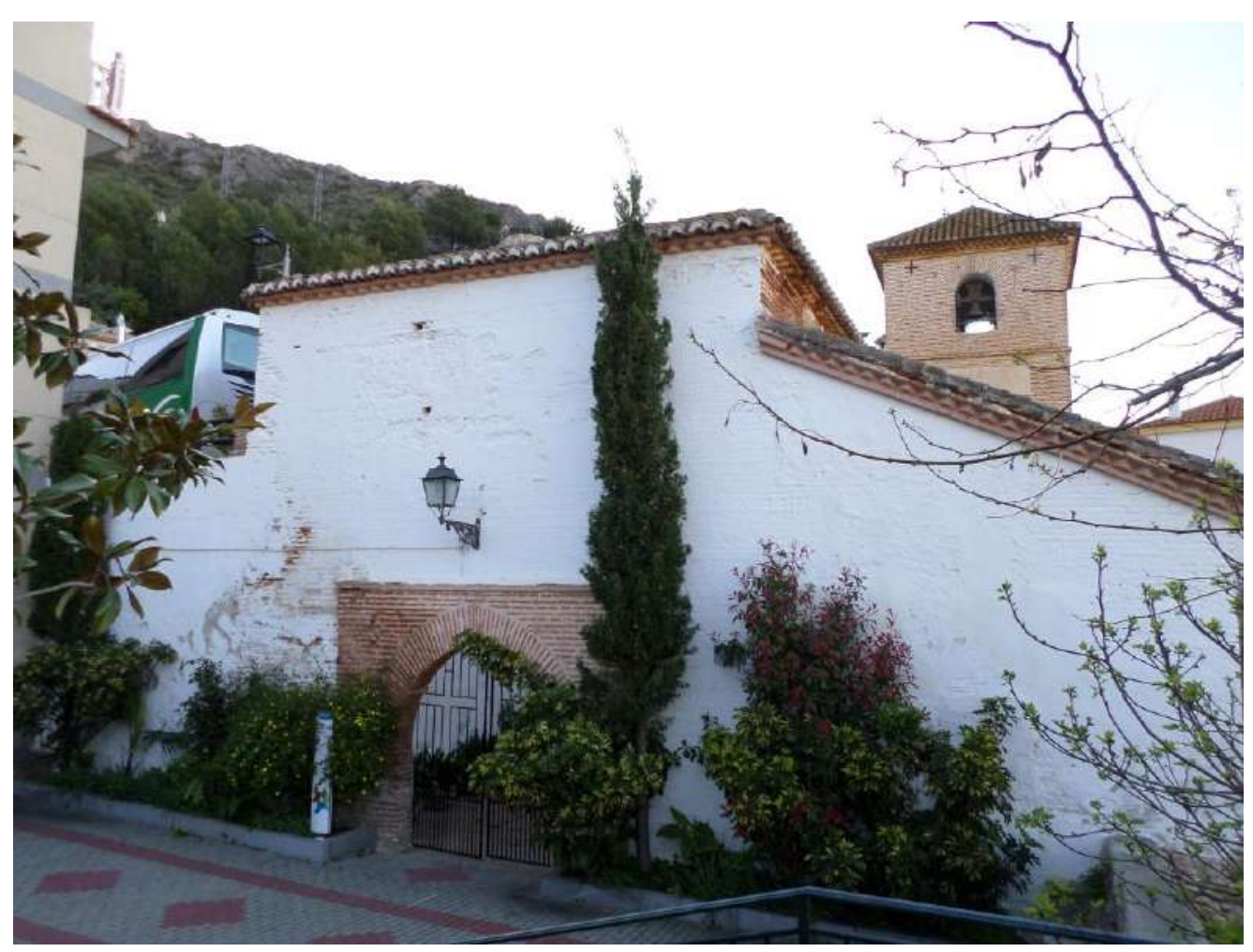

6) Fachada de la primitiva iglesia.

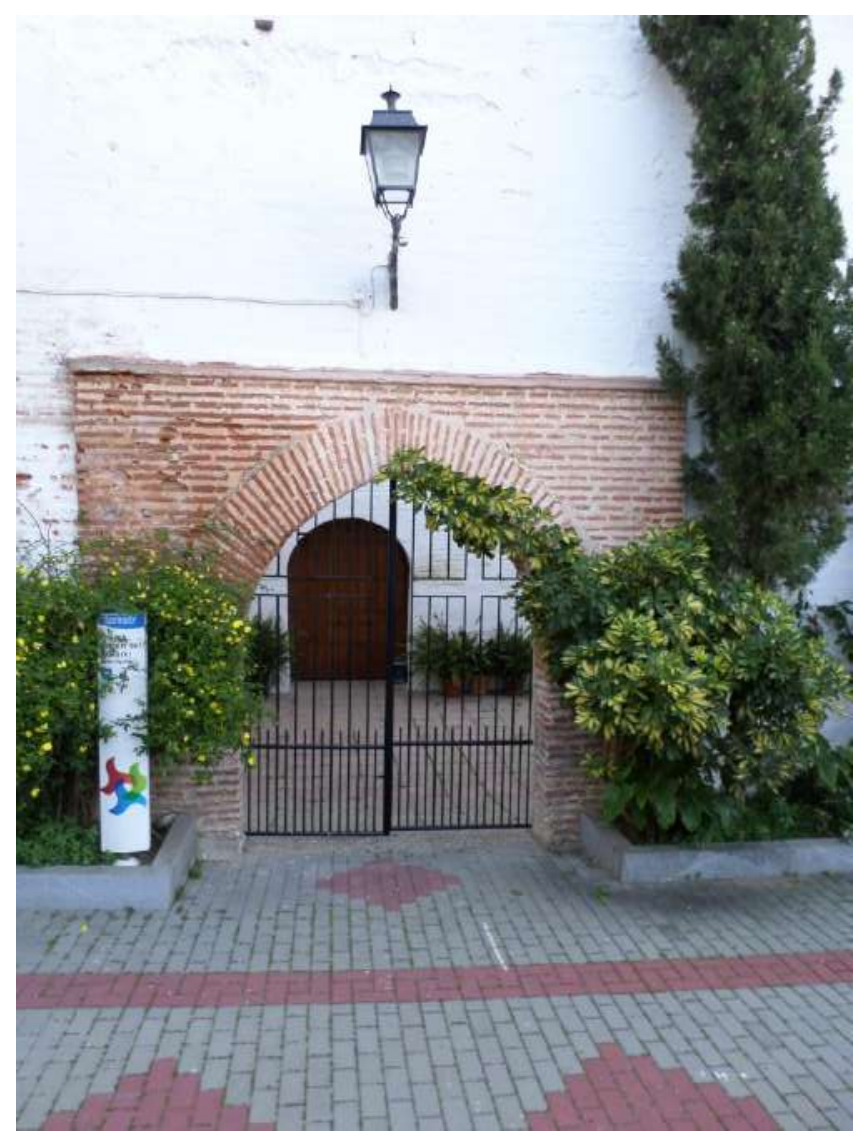

7) Portada de la fachada de la primitiva iglesia, acceso al actual atrio. 


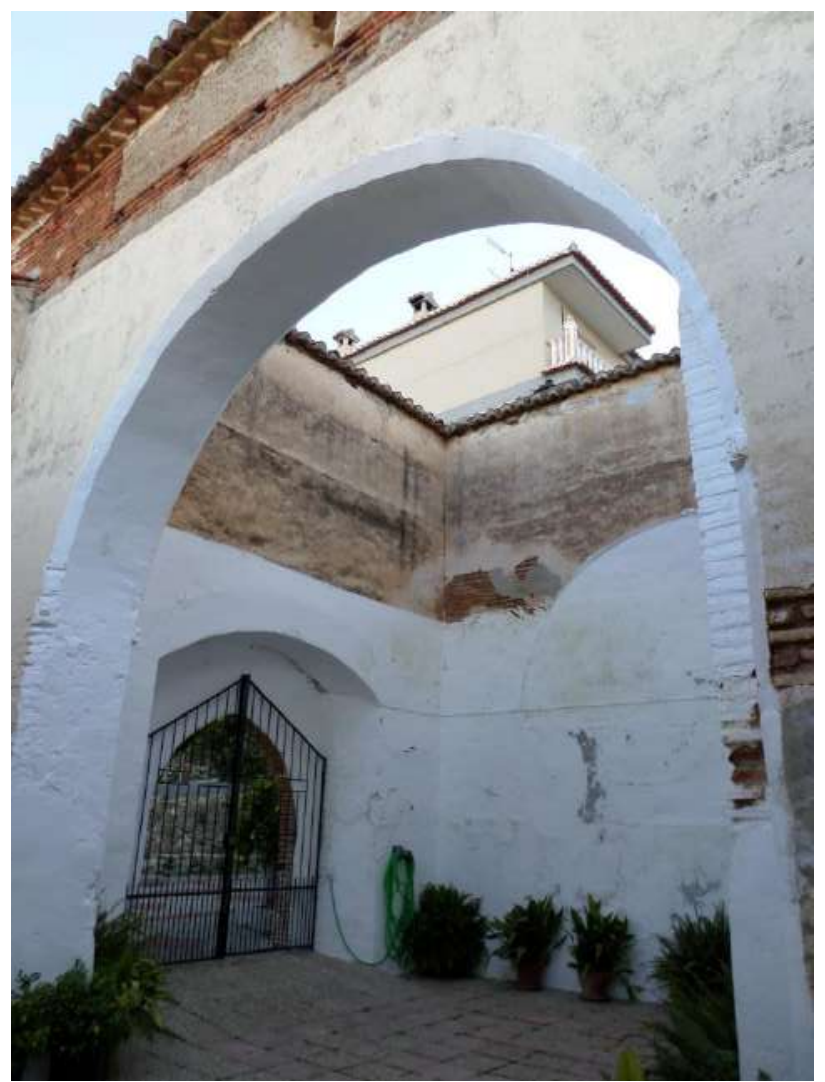

8) Vista del atrio (primer tramo de la primitiva iglesia).

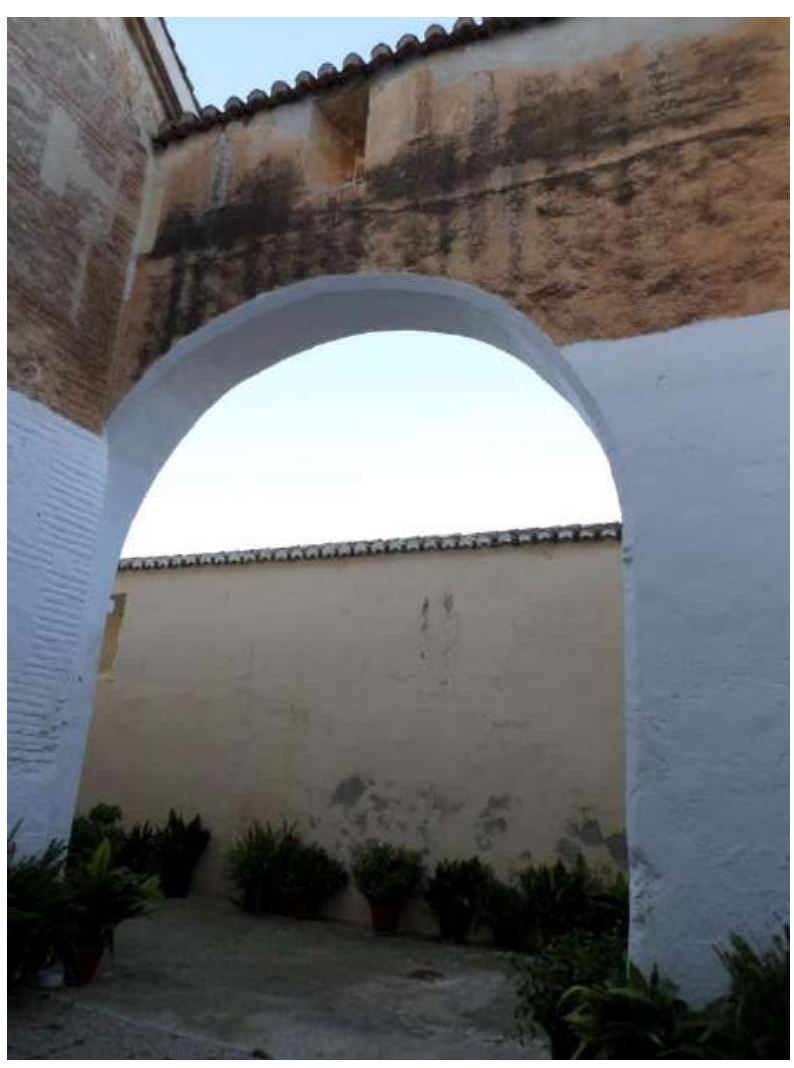

9) Arco de acceso a la nave lateral de la primitiva iglesia (se convirtió en cementerio). 


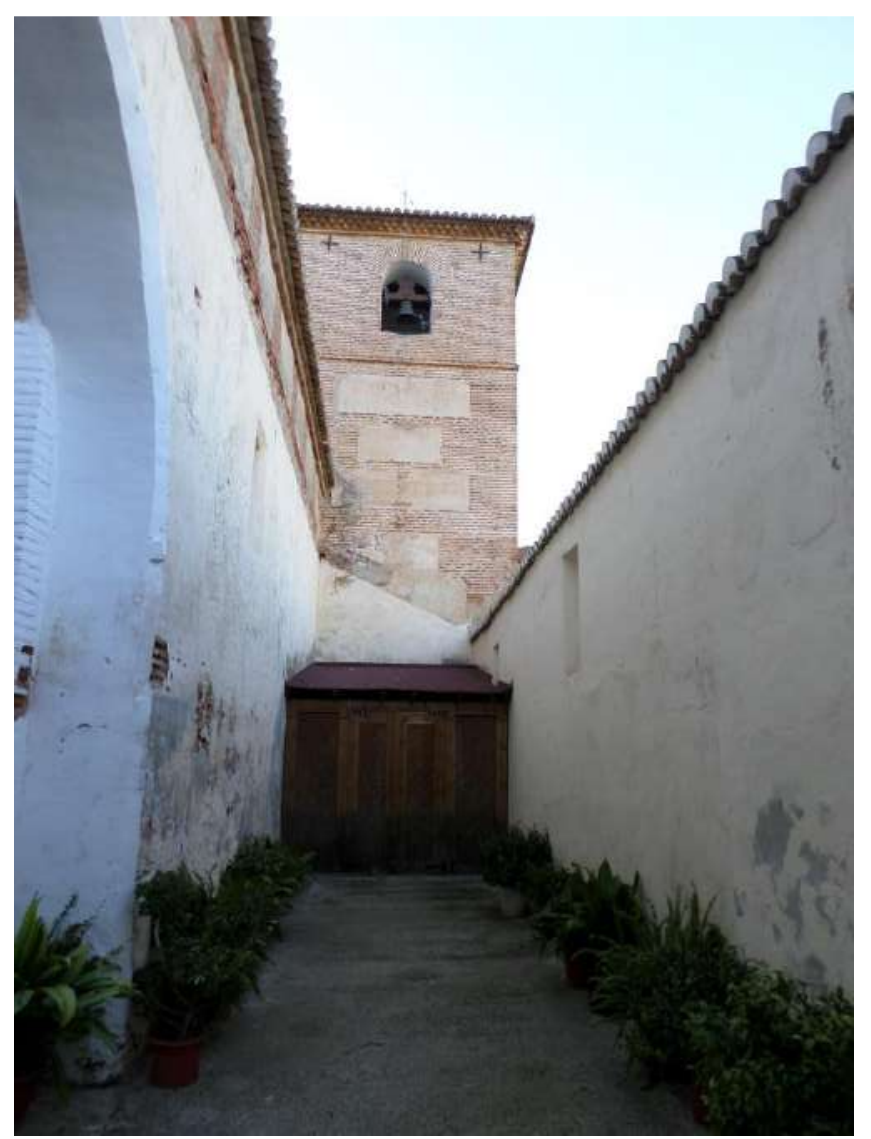

10) Nave lateral derecha de la primitiva iglesia.

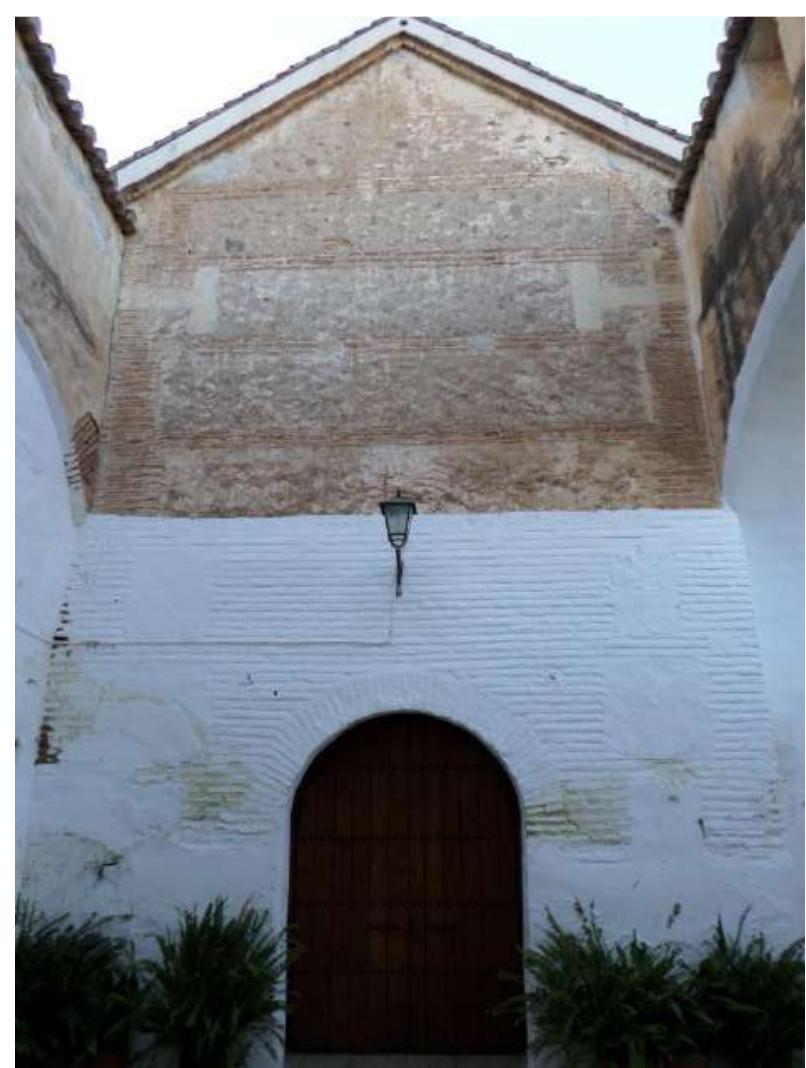

11) Fachada principal de la actual iglesia. 


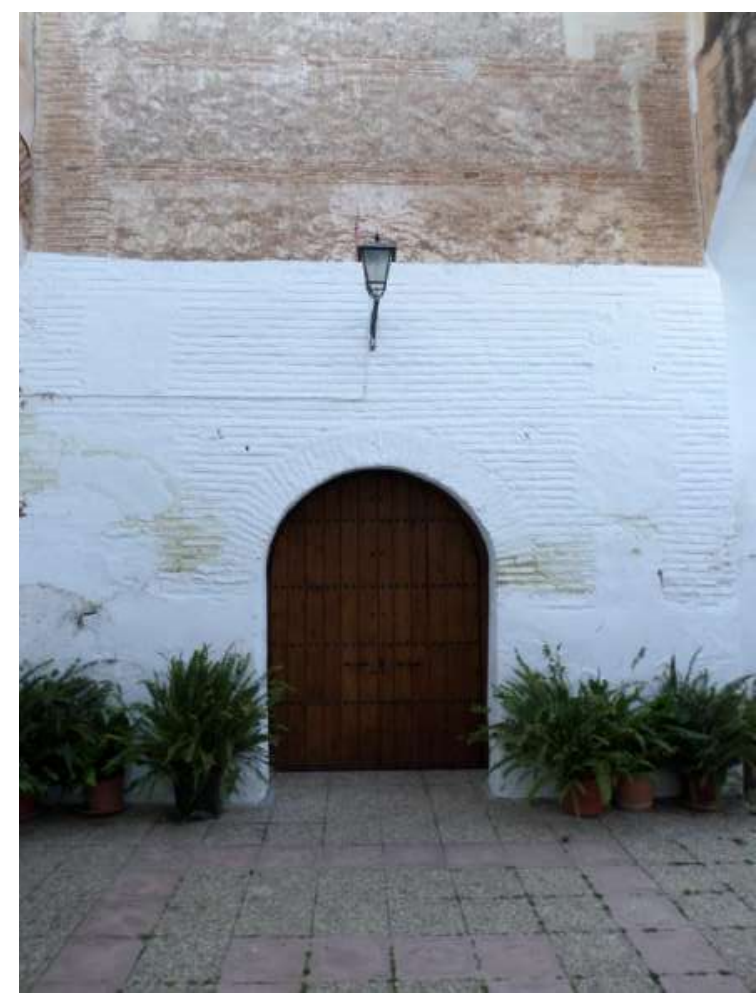

12) Portada de la actual iglesia.

En el interior del templo de la actual iglesia, hay que indicar que los muros son gruesos y cumplen la función de cerramiento de todo el templo de finales del s. XVI y sustento de los elementos superiores tanto de madera como de piedra y ladrillo, además estos muros dan gran sensación de solidez en todo el edificio, teniendo tan solo un vano adintelado en el muro lateral derecho que ilumina la nave de la iglesia. Esta nave está cubierta por una armadura de par y nudillo, con tirantes pareados sostenidos por canes de acanto en toda la armadura. Hay que indicar que esta armadura tiene un único tirante con canes de acanto en los extremos, y no tiene almizate. Los pares de la armadura no tienen decoración, siendo una armadura llana. La capilla mayor también está cubierta por una armadura, pero en está ocasión es de par e hilera, con almizate y cuadrales sostenidos por canes lobulados. El almizate de esta armadura está decorado por chillas, aunque los pares no presentan decoración ninguna. El coro está sostenido por un alfarje que contiene una única jácena con diez jaldetas que sostienen las tablazones sin ningún tipo de decoración. El alfarje está sostenido por dos columnas dóricas de hormigón. 


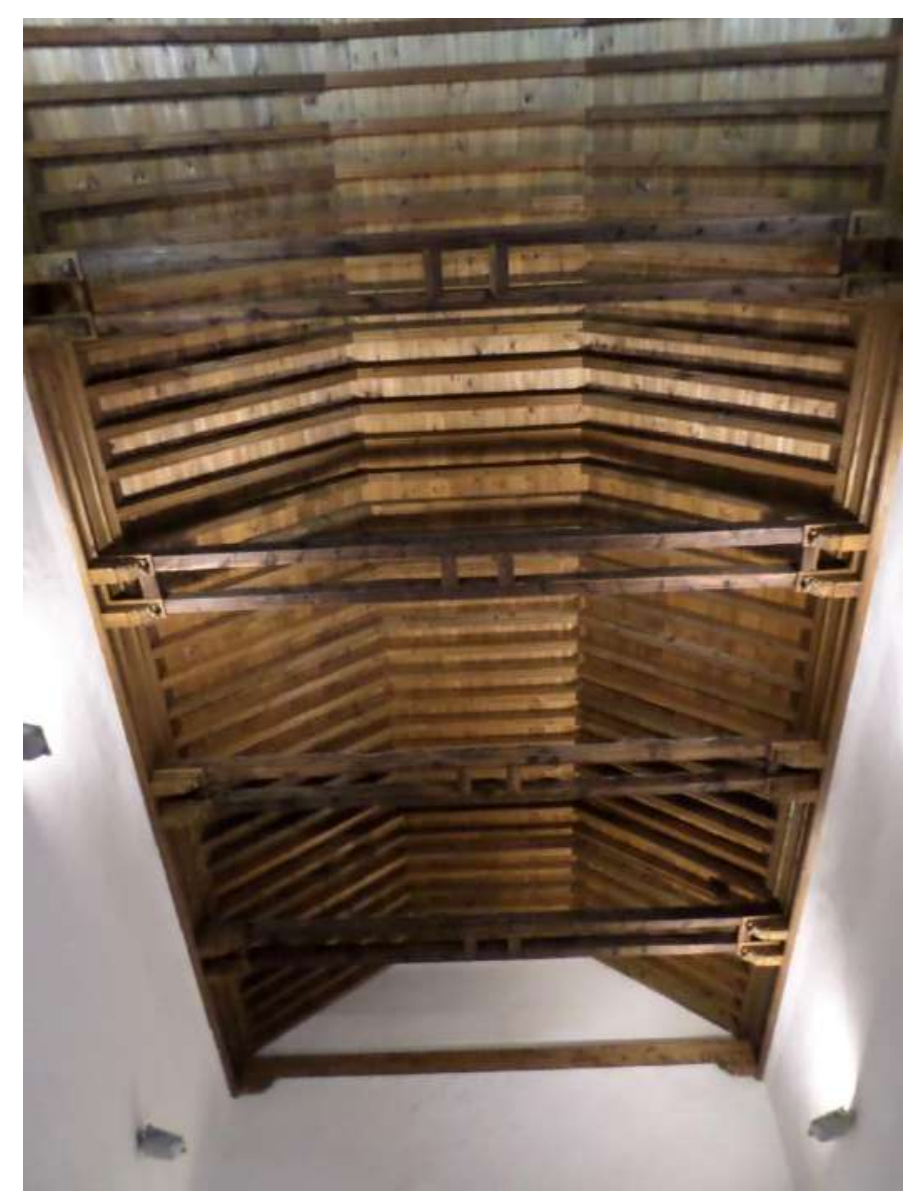

13) Armadura de la nave de la iglesia.

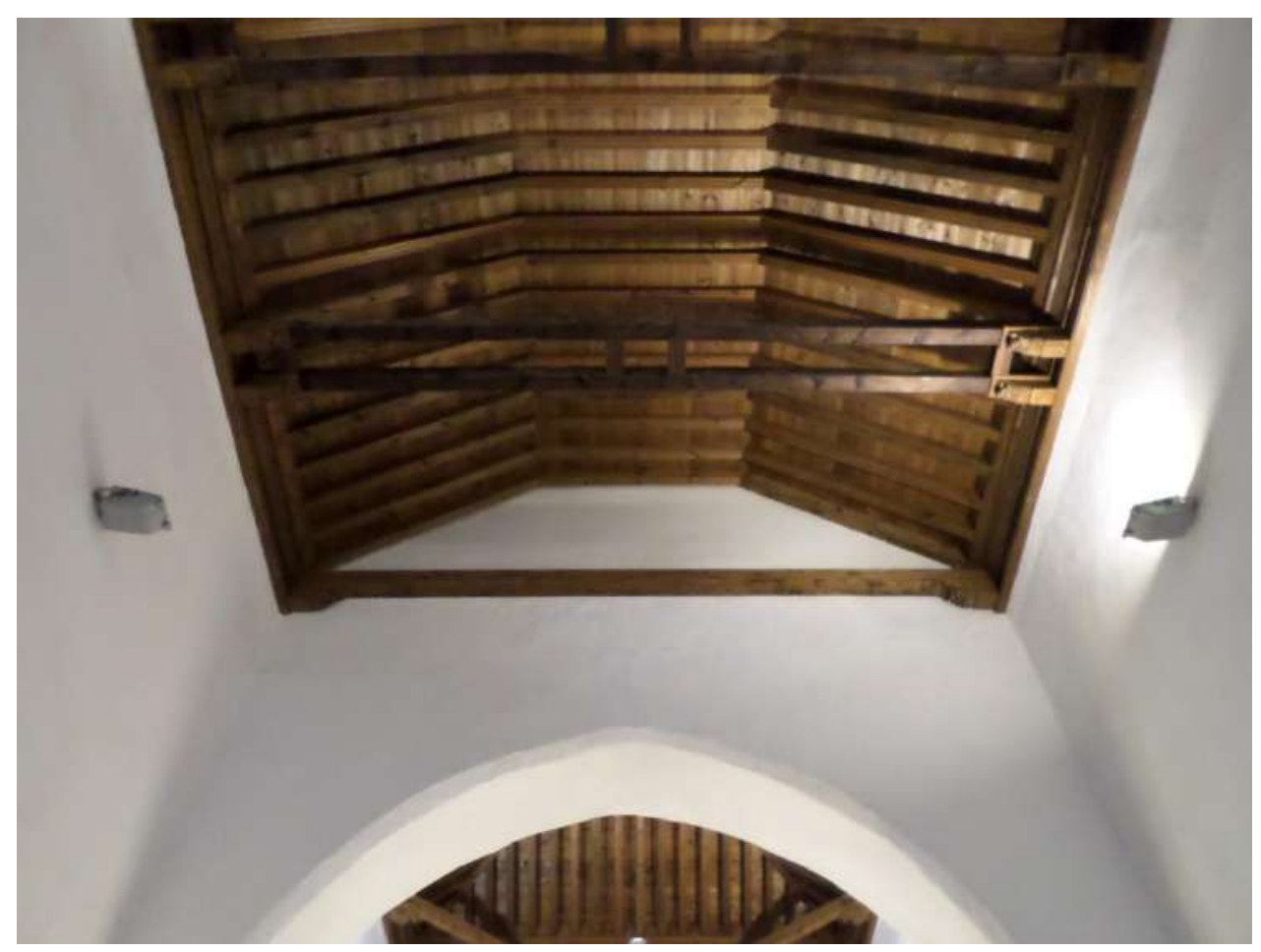

14) Detalle de la armadura de la nave de la iglesia. 


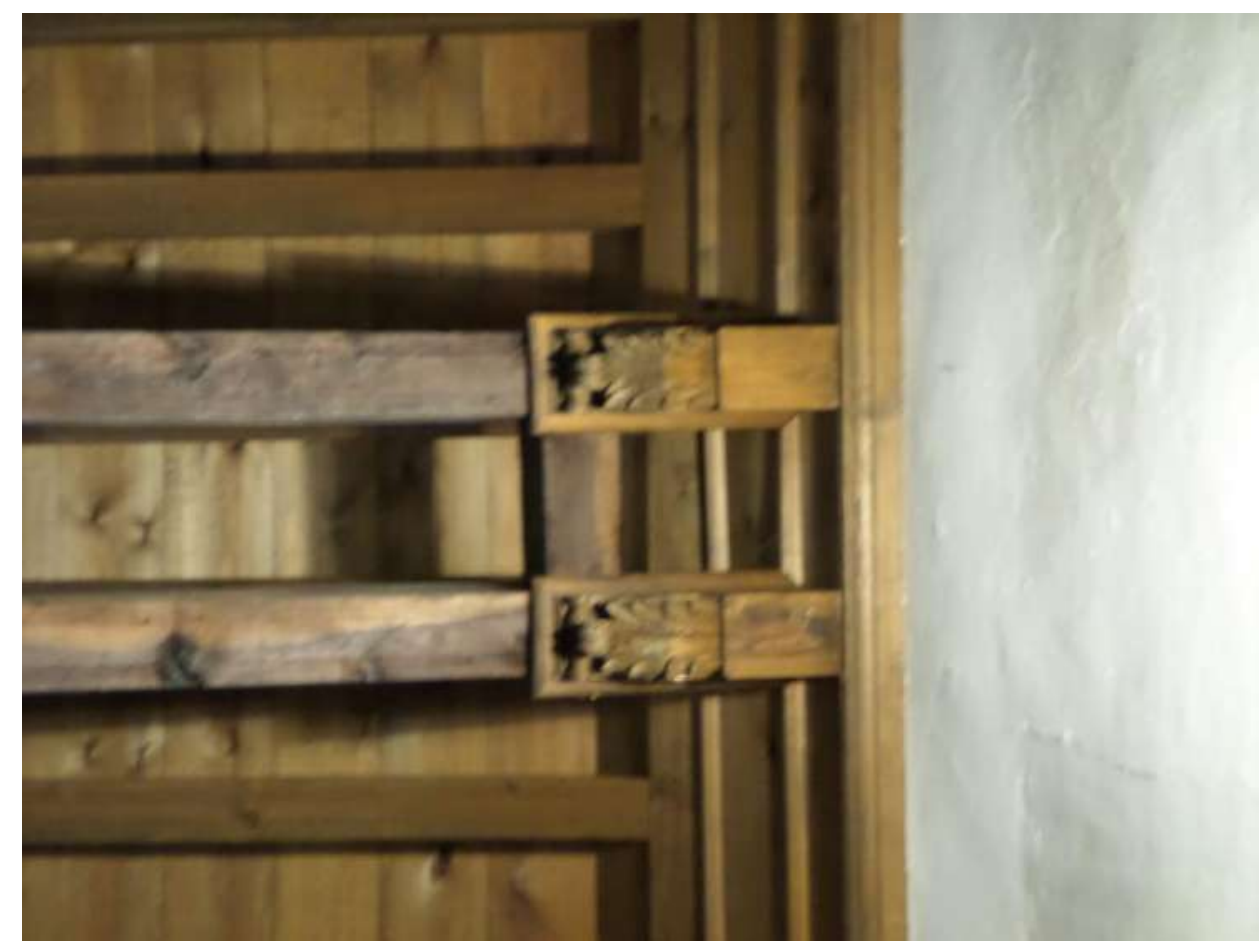

15) Canes de acanto de la armadura de la nave de la iglesia.

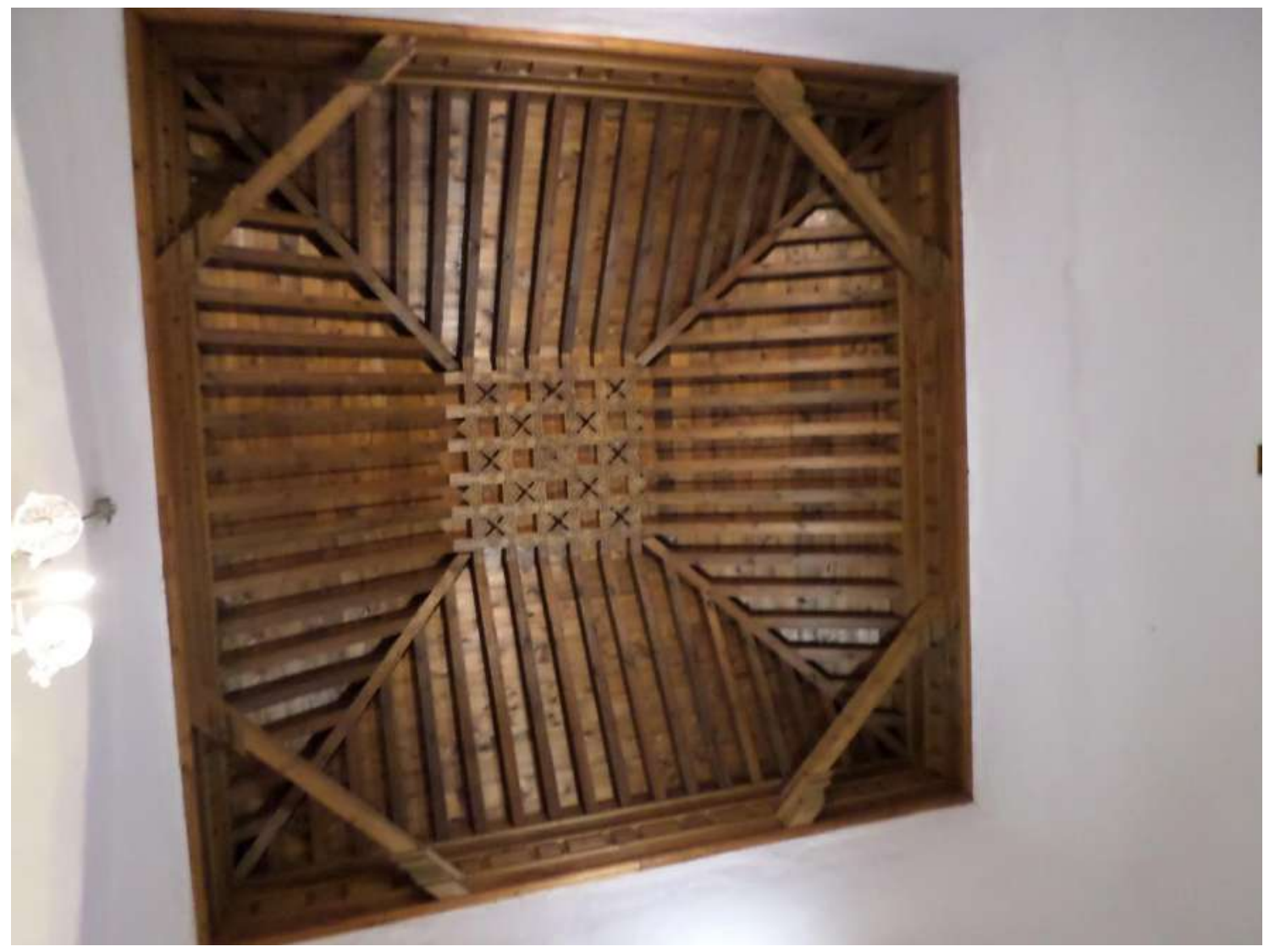

16) Armadura de la capilla mayor. 


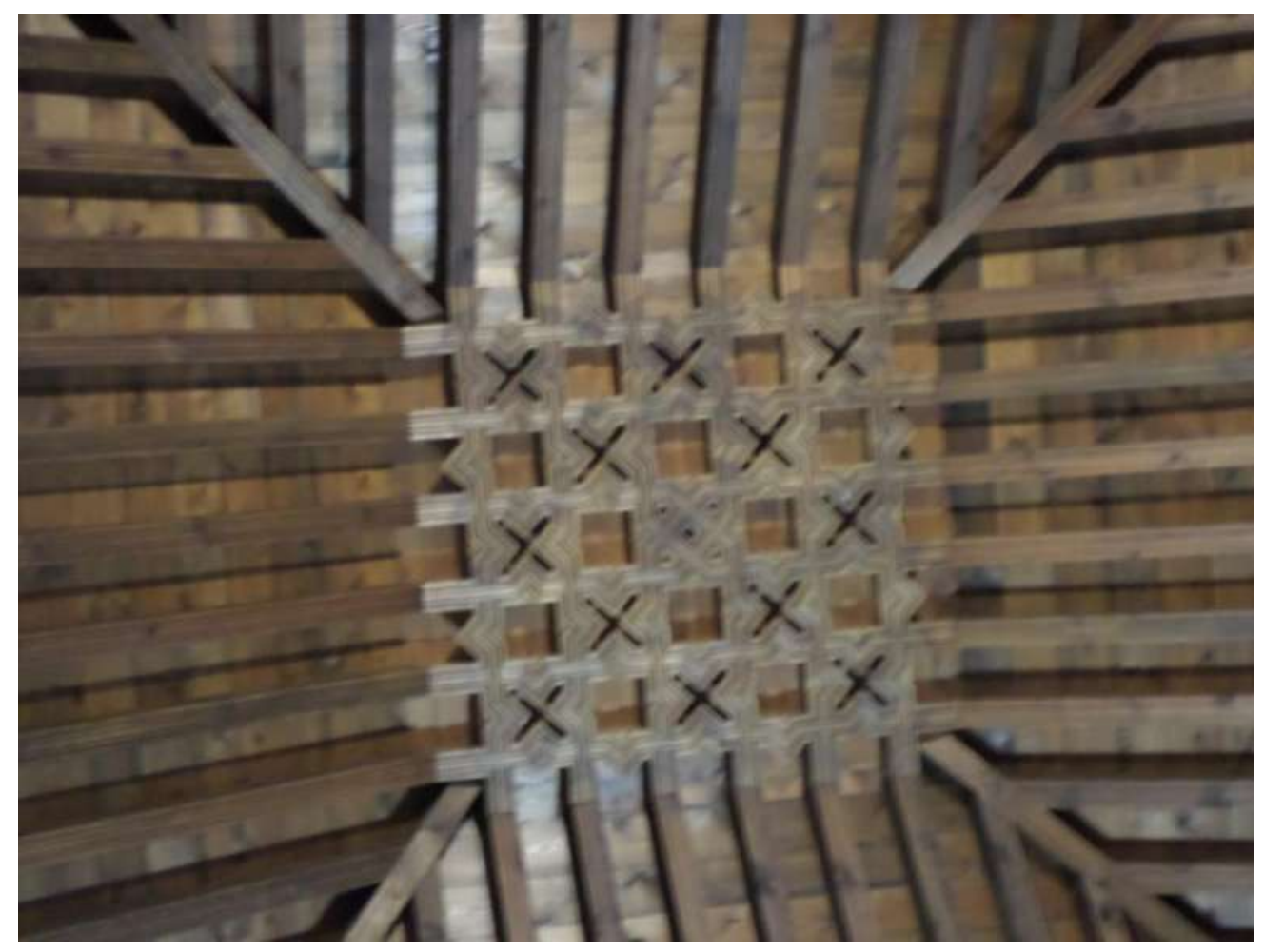

17) Almizate de la armadura de la capilla mayor.

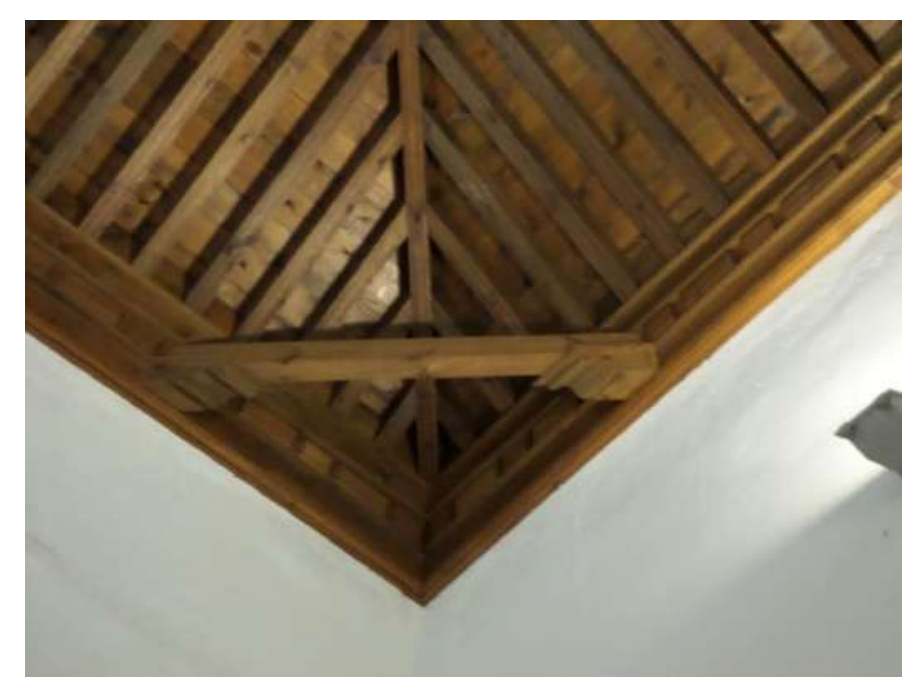

18) Cuadral con canes lobulados de la armadura de la capilla mayor. 


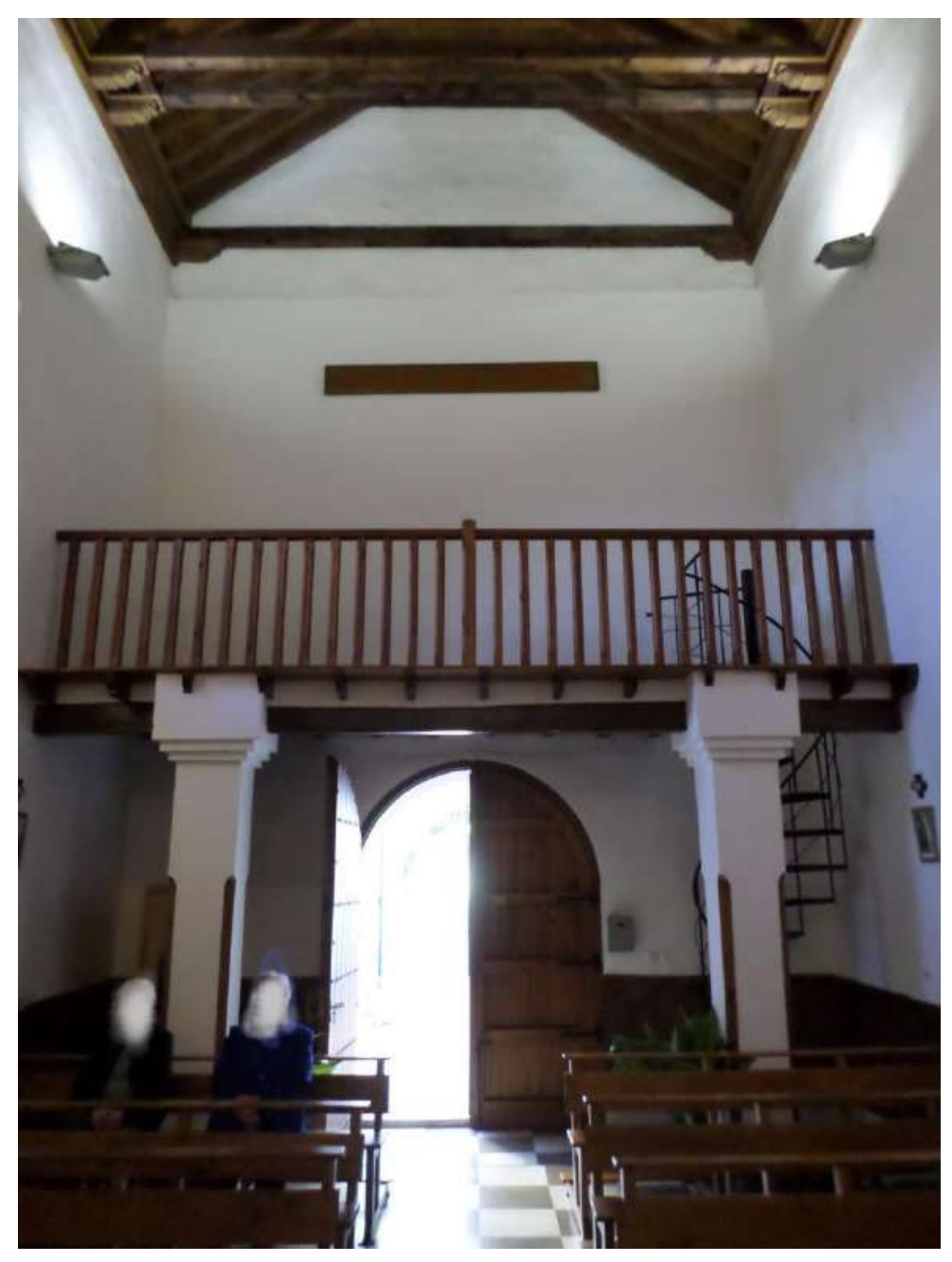

19) Alfarje del coro. ${ }^{57}$

${ }^{57}$ La foto se repite. 


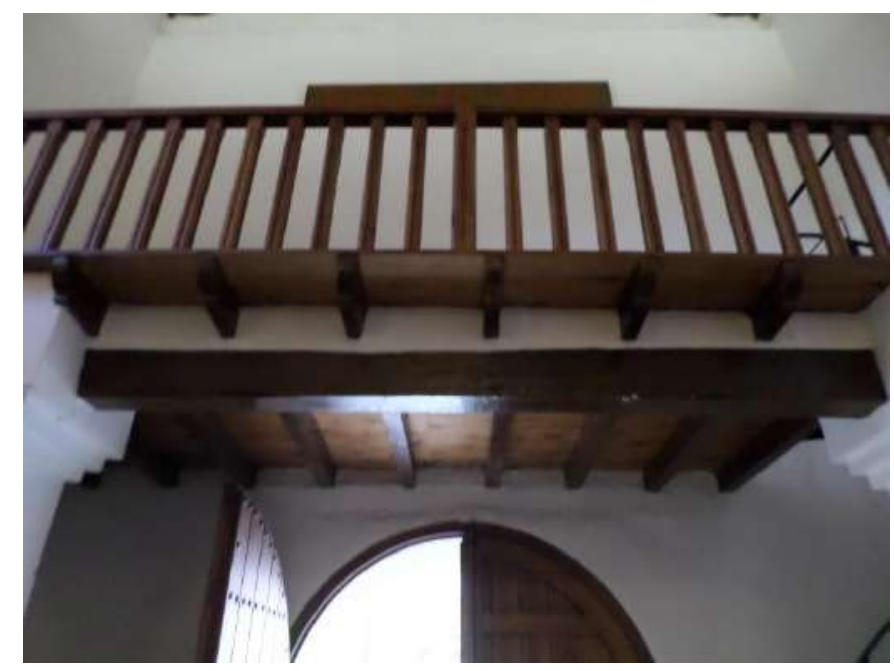

20) Detalle del alfarje del coro.

Por último, hemos de comentar la torre que se encuentra situada en el lado NE de la iglesia. La torre está construida en cintas de ladrillo y yeso, y el último cuerpo, separado del resto de la torre por una cornisa, tiene las campanas que se sitúan en arcos de medio punto construidas en ladrillo.

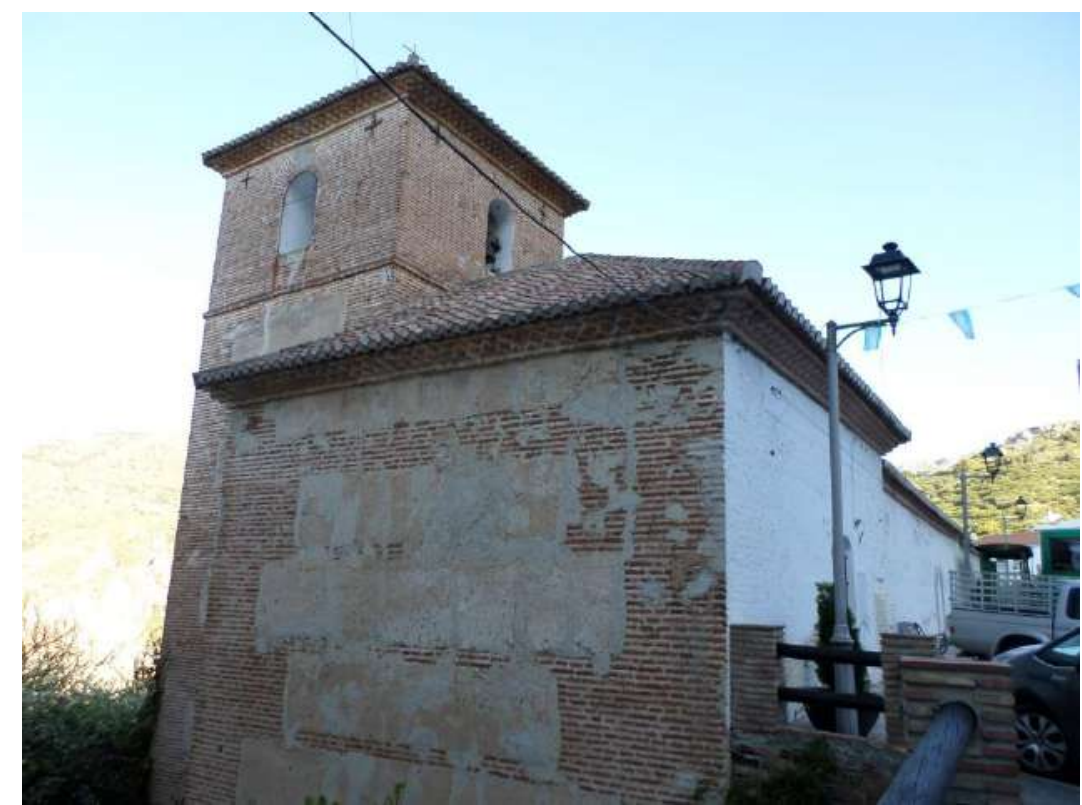

21) Vista de la torre. 


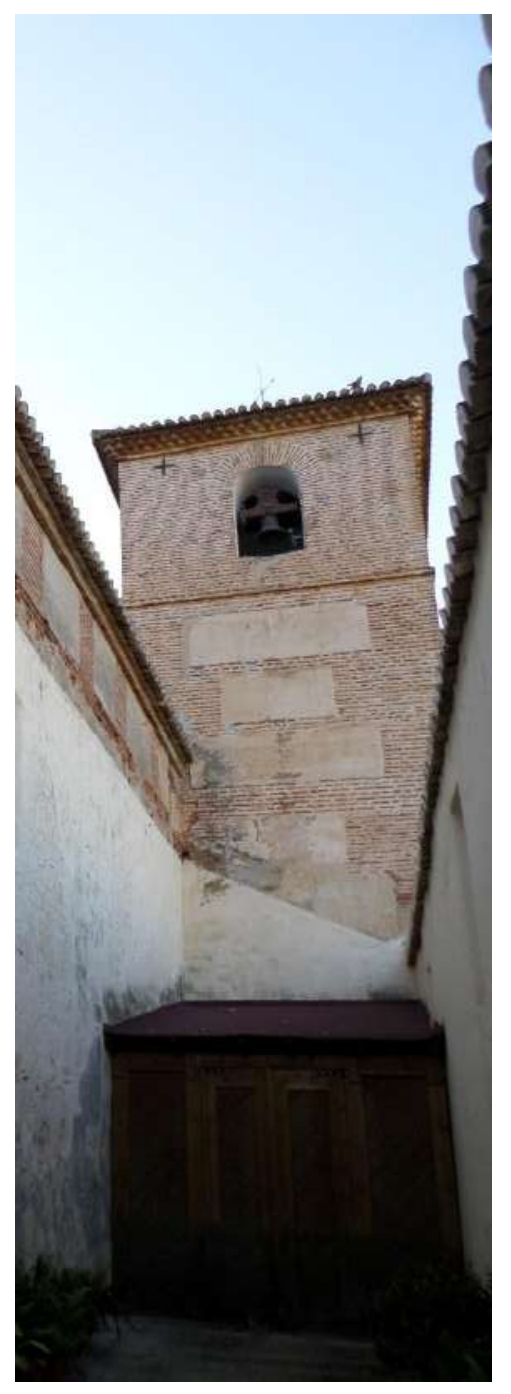

22) Torre.

De la iglesia que hemos descrito, la parte mudéjar sería, en primer lugar, la predominante estructura espacial. Del gran espacio exterior, las cintas de ladrillo y yeso que aparecen toda la estructura de la primitiva iglesia destruida en el alzamiento morisco y también en la estructura de la actual iglesia, en la torre y en el actual atrio. Las predominantes y grandes portadas del atrio con su arco apuntado rodeados por un alfiz, y el arco de medio punto de ladrillo de la fachada principal de la iglesia actual. Del bello interior, hemos de mencionar como predominantemente mudéjar, la hermosa armadura de la nave de la iglesia, el antiguo alfarje del coro y la gran armadura de la capilla mayor.

\subsection{Iglesia Parroquial de Nuestra Señora de la Concepción de Otívar.}

La Iglesia Parroquial de Nuestra Señora de la Concepción fue construida en el s. XVI, aunque posteriormente ha sido renovada y reformada en sus elementos 
esenciales. ${ }^{58}$ Los principales materiales de construcción que se emplearon en el templo han sido la piedra, el ladrillo, el yeso y la madera, aunque la piedra, el ladrillo y el yeso están revocados en todo el exterior, incluida la torre.

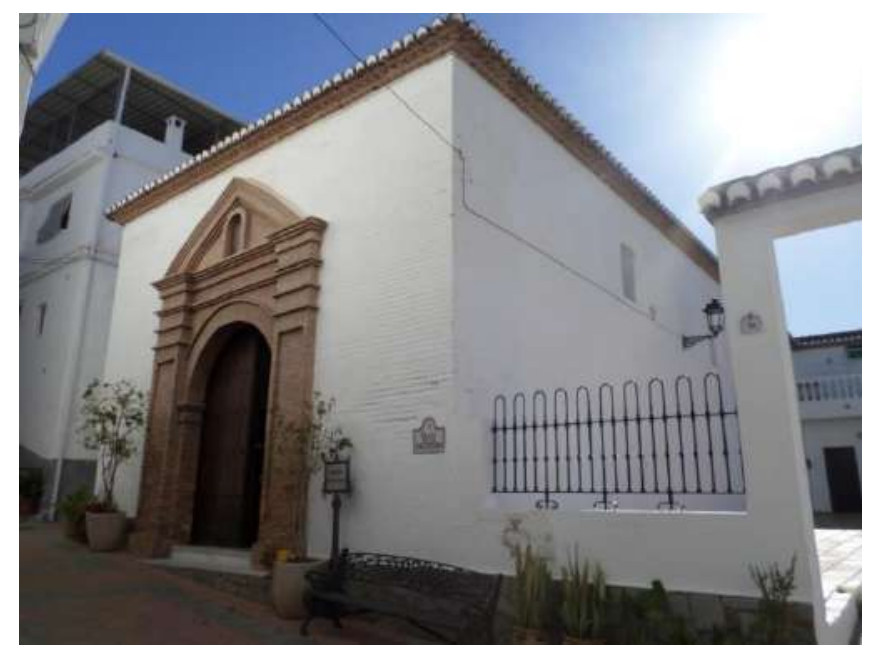

1) Iglesia Parroquial de Nuestra Señora de la Concepción de Otívar.

La iglesia tiene una única nave rectangular sin capilla mayor diferenciada ${ }^{59}$, y la nave presenta coro a los pies.

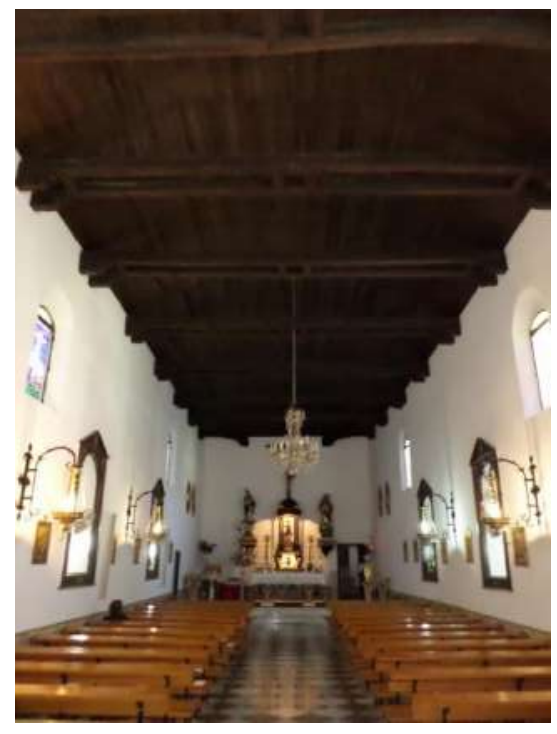

2) Nave de la iglesia.

${ }^{58}$ VV.AA. Guía artística de Granada y su.... Op. cit., pág. 176

${ }^{59}$ Este tipo de planta de nave única rectangular sin capilla mayor diferenciada cubierta por armadura, como se describe más adelante, responde a las tipologías de planta de iglesias mudéjares de Granada según el estudio realizado por Don Rafael López Guzmán y Don Ignacio Henares Cuéllar en:

- $\quad$ HENARES CUÉLLAR, Ignacio; LÓPEZ GUZMAN, Rafael. Arquitectura Mudéjar.... Op. cit. 


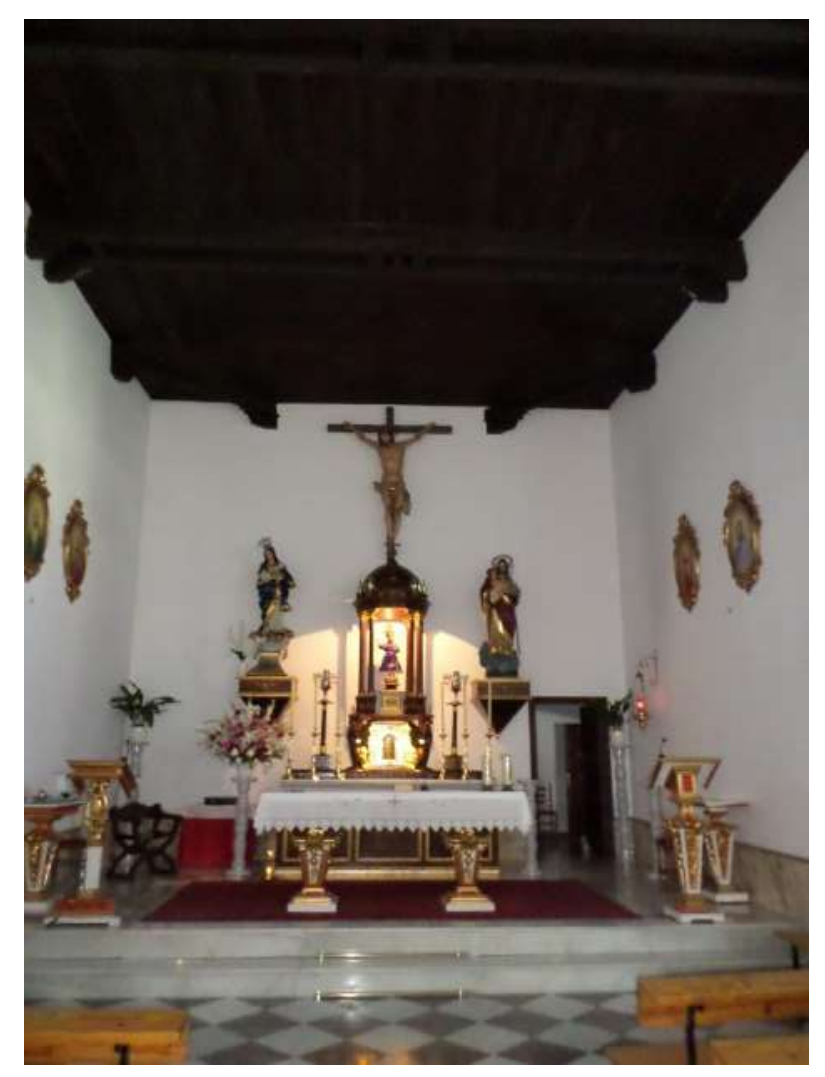

3) Capilla mayor no diferencia.

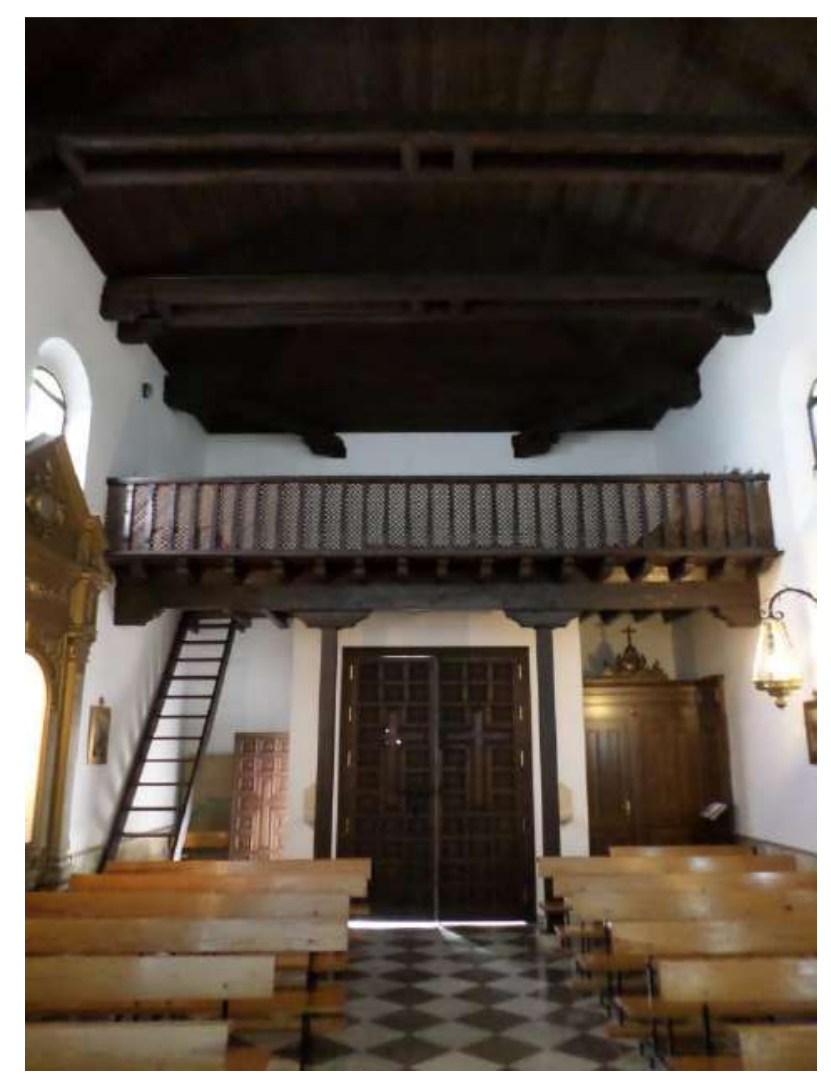

4) Coro. 
En el exterior, hemos de indicar que está construido en cintas de ladrillo y yeso, pero como hemos indicado al comienzo, está revocado, algo que no era así antes de la Guerra Civil española, ${ }^{60}$ perdiendo todo el esplendor mudéjar que tenía en tiempos pasados. La fachada principal también está muy transformada por lo que hemos descrito del revoco y en ella se encuentra la puerta de acceso enmarcada por una predominante portada de ladrillo moderna. Esta portada de ladrillo consta de un arco de medio punto sostenido por pilastras dóricas rodeado por pilares con doble capitel dórico que sostienen un arquitrabe liso que a su vez sostiene un frontón triangular en cuyo centro aparece una hornacina.

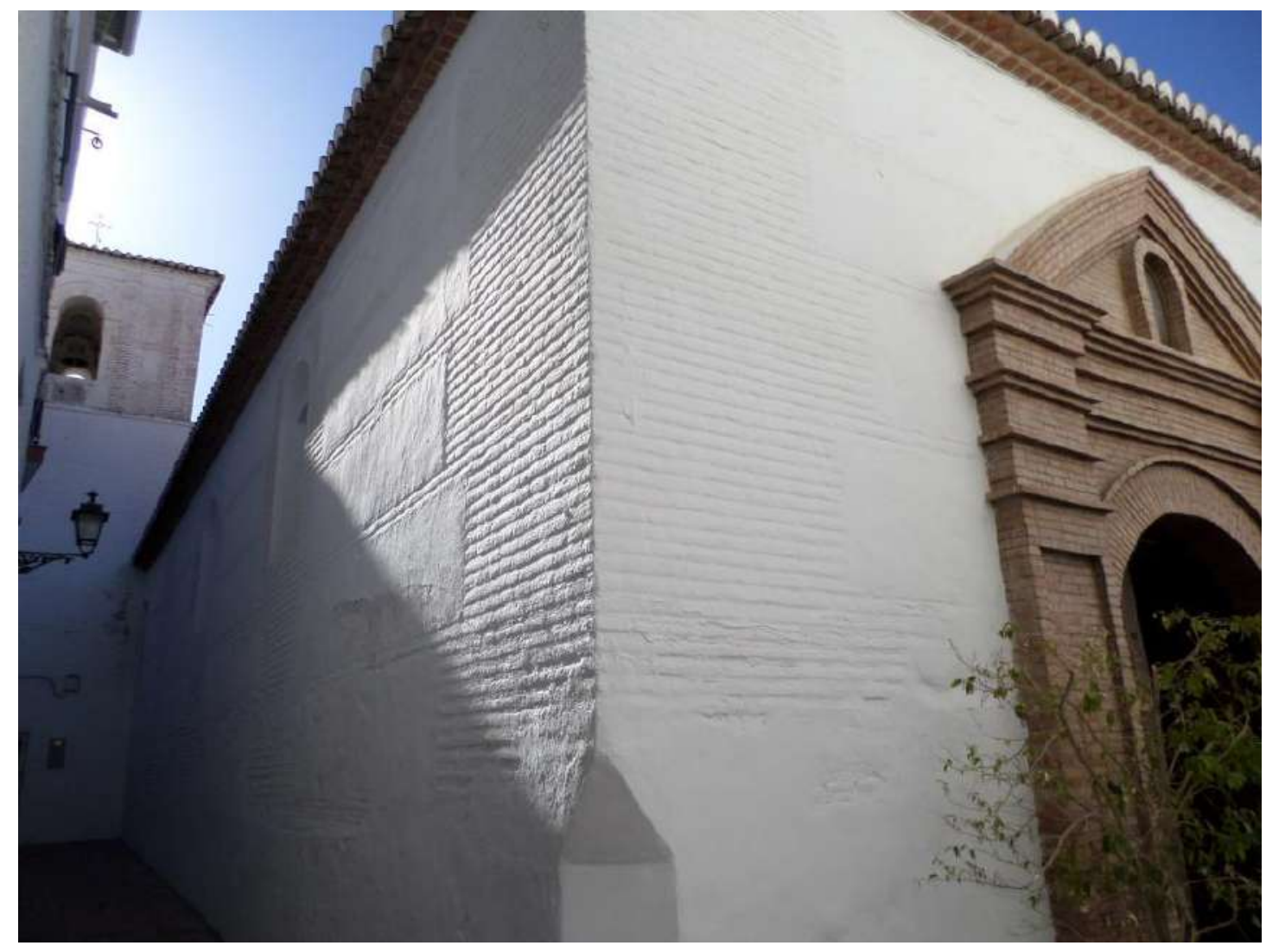

5) Lateral izquierdo de la iglesia.

\footnotetext{
${ }^{60}$ Esto lo conocemos por testimonios de los vecinos.
} 


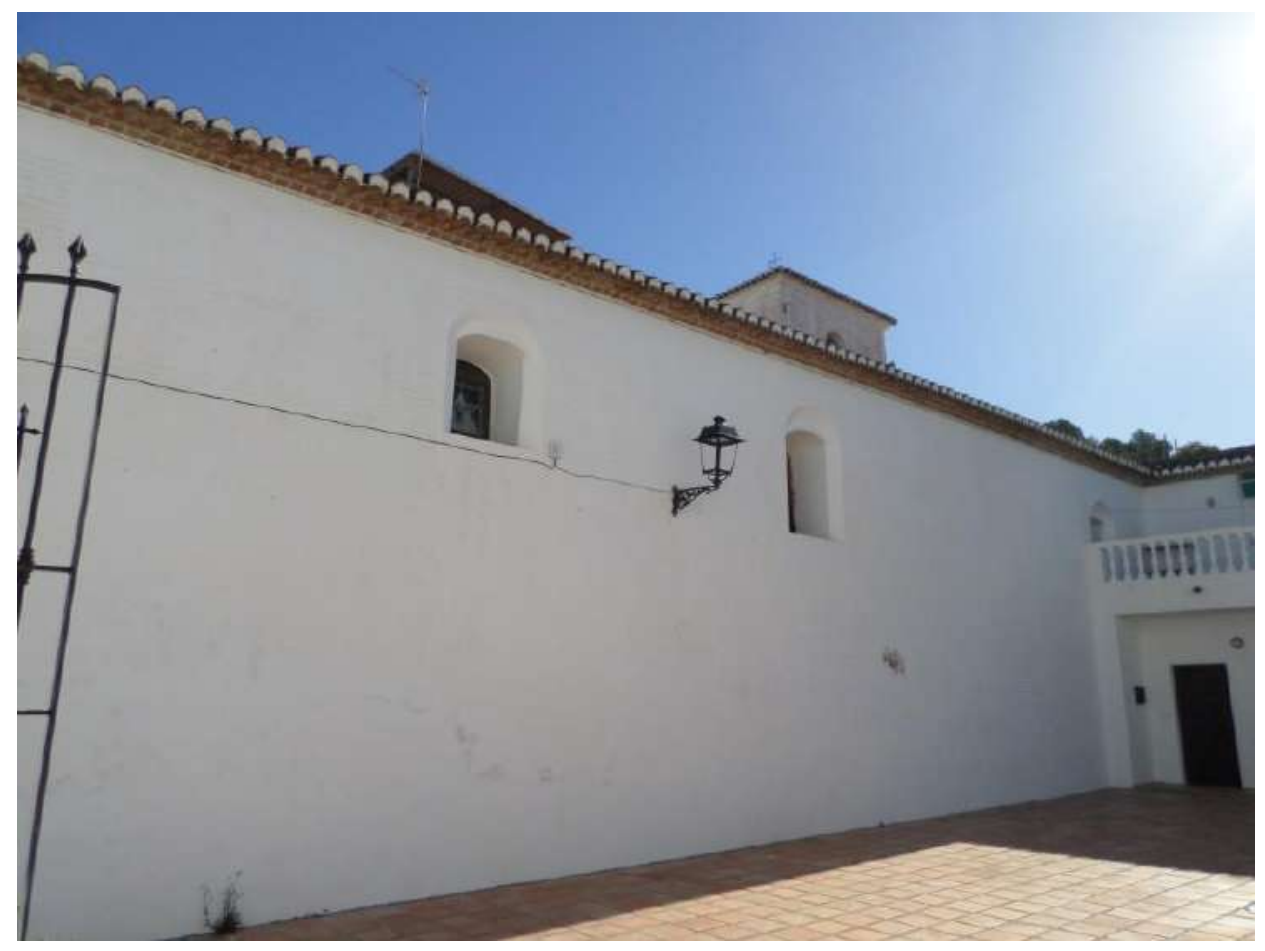

6) Lateral derecho de la iglesia.

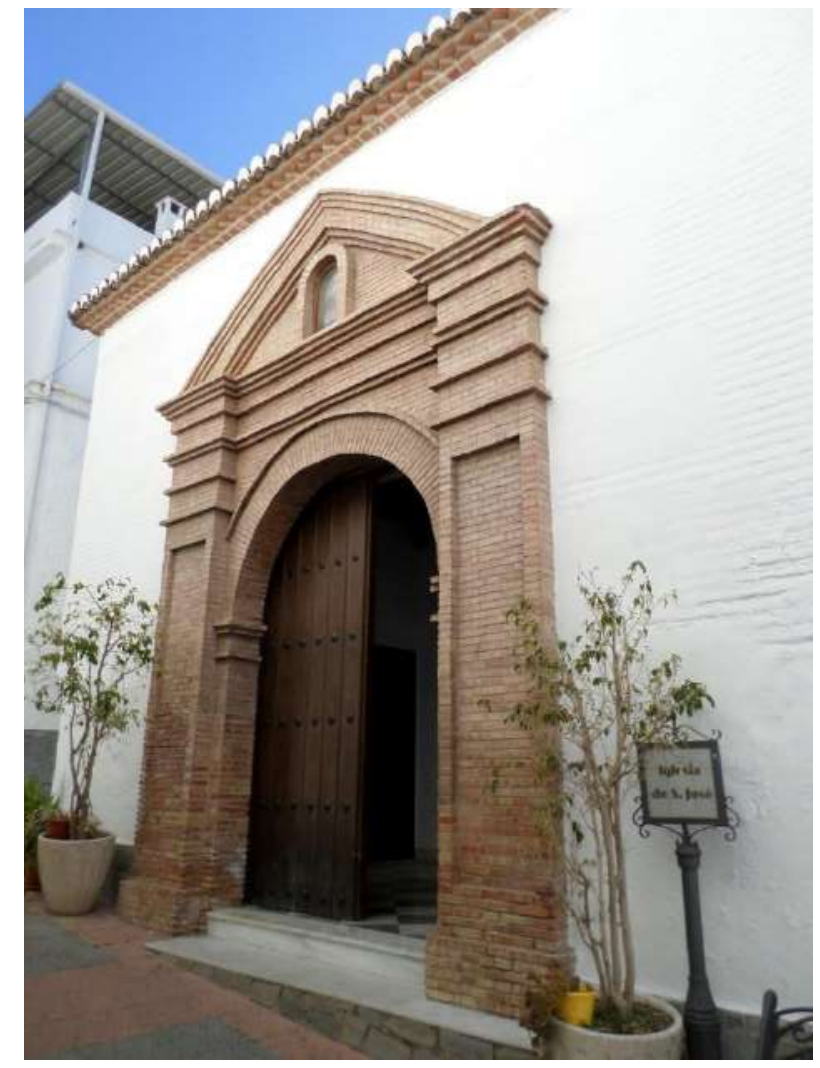

7) Portada de la iglesia.

En el interior del templo, hay que describir que los grandes muros cumplen la función de cerramiento del extenso espacio de la iglesia y de descarga de los elementos 
superiores de madera y dan también gran sensación de solidez. El muro lateral izquierdo presenta dos vanos de arco de medio punto rodeados por un alfiz que ilumina la nave de la iglesia, y el muro lateral derecho tiene tres vanos de arco de medio punto que también da luz a la nave. Esta nave está cubierta por una armadura moderna que imita a la original de lima bordón, pero solo en sus formas, ya que es muy simple, quedando solo de la primitiva armadura los tirantes pareados sostenidos por canes lobulados y los cuadrales sostenidos también por canes lobulados. El coro está sostenido por un alfarje que tiene una única jácena con canes lobulados y está divido por el sotocoro por lo que las jaldetas están formadas en dos grupos, el grupo de la derecha contiene dos jaldetas y el grupo de la izquierda cuatro jaldetas, sobre las que se colocan las tablazones. Estas tablazones no presentan ningún tipo de decoración, en cambio los extremos de las jaldetas tienen decoración de lóbulos y en su parte inferior una decoración en forma circular. El alfarje está sostenido por dos columnas de madera con doble capitel lobulado que se sitúan en la jácena.

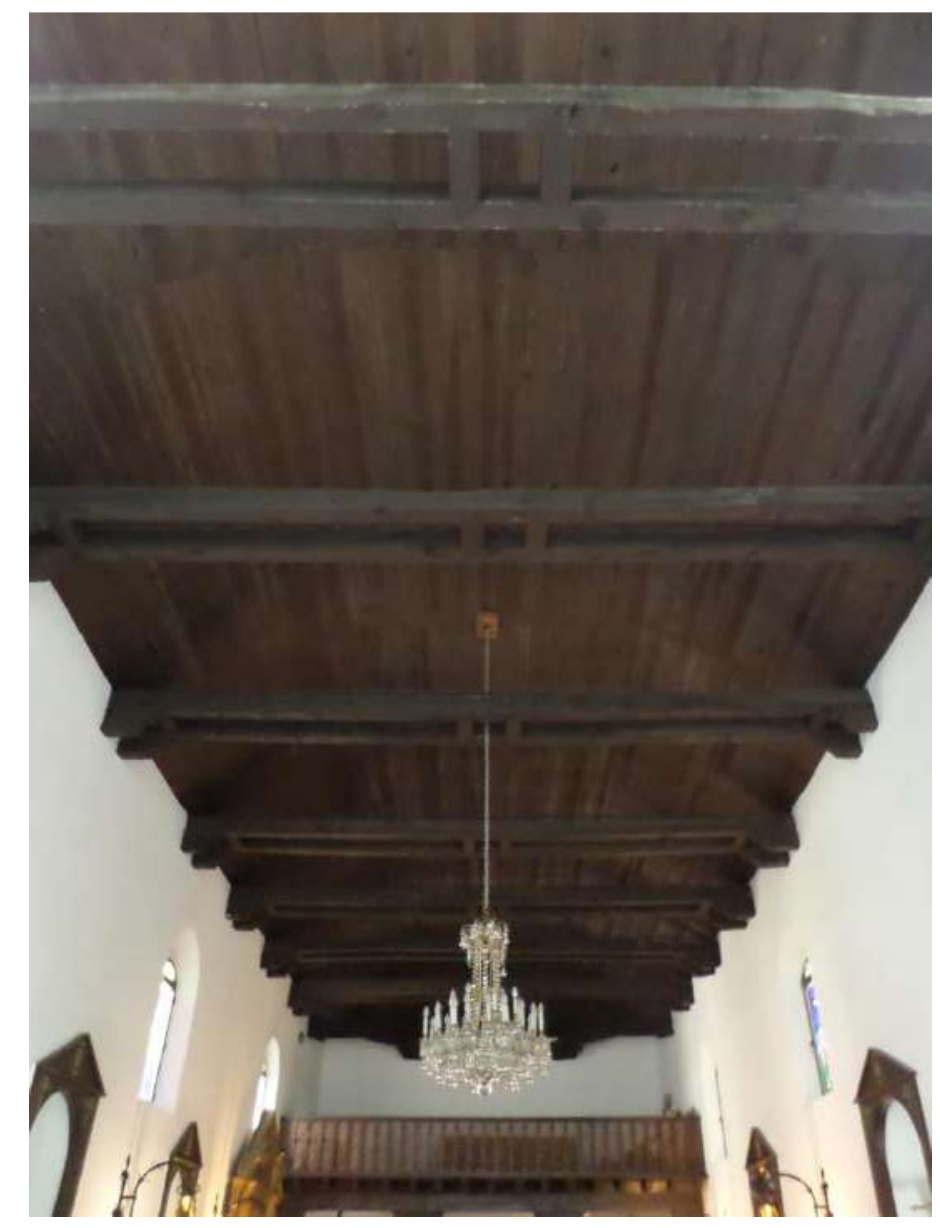

8) Armadura reconstruida de la nave de la iglesia. 


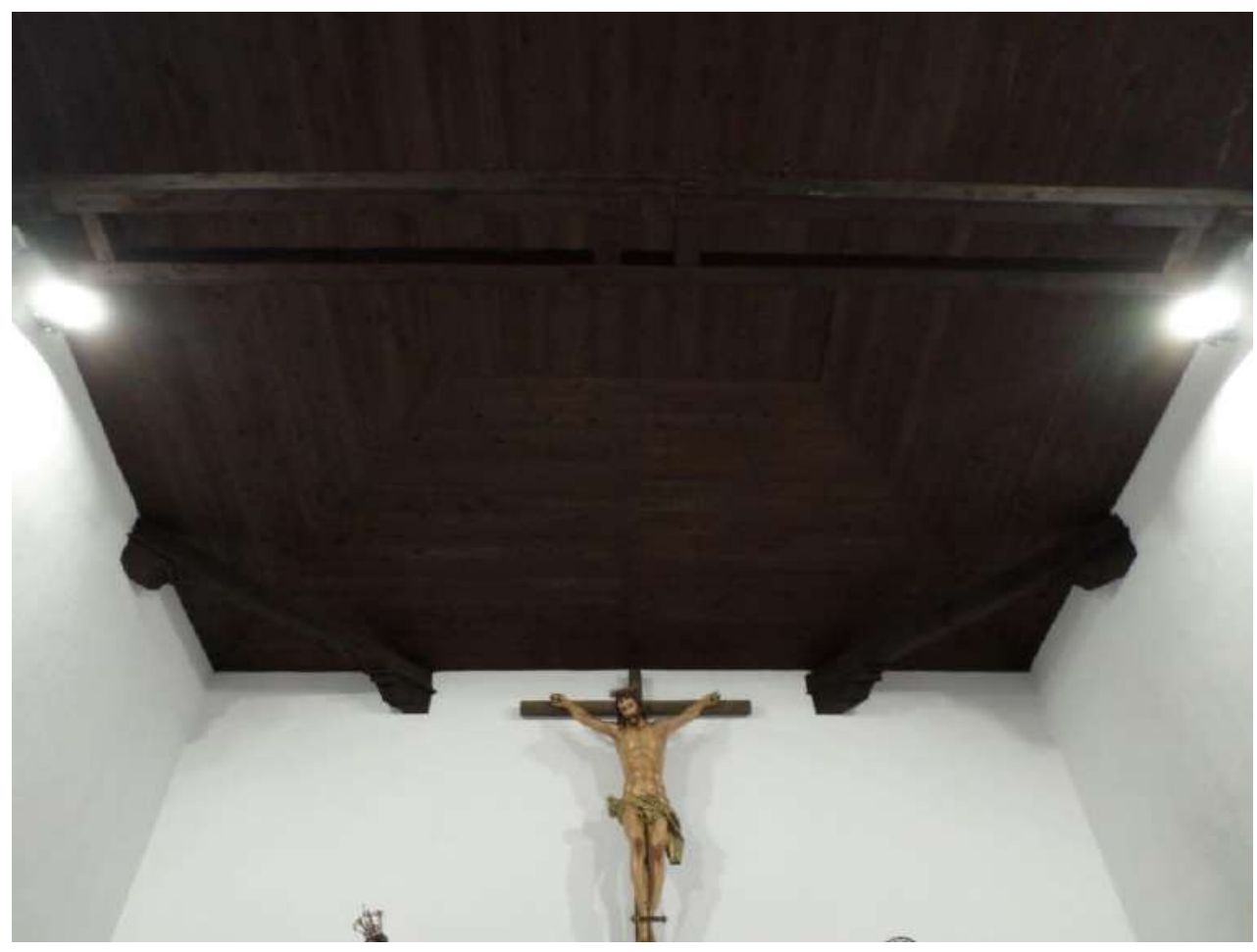

9) Detalle de la armadura de la nave de la iglesia.

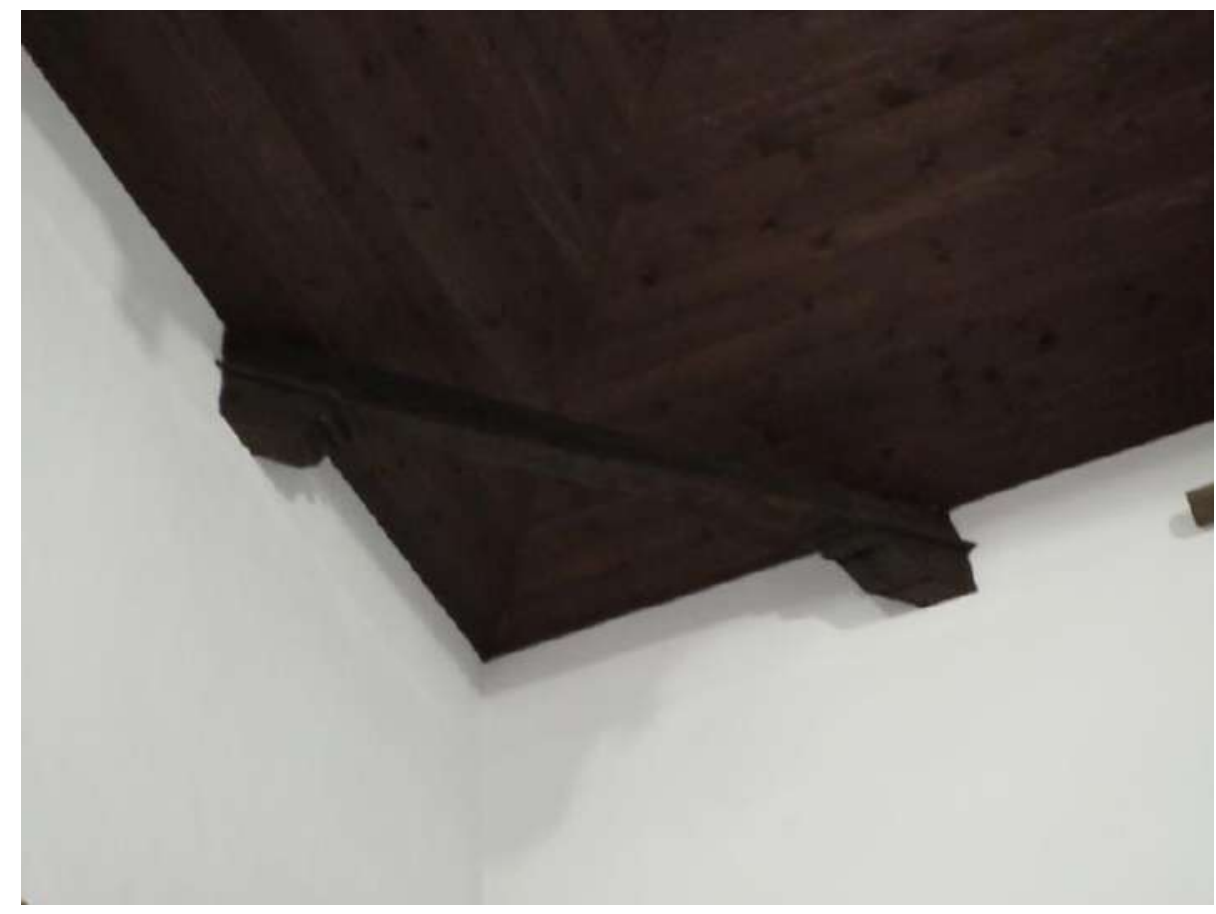

10) Cuadral con canes lobulares de la armadura de la nave de la iglesia. 


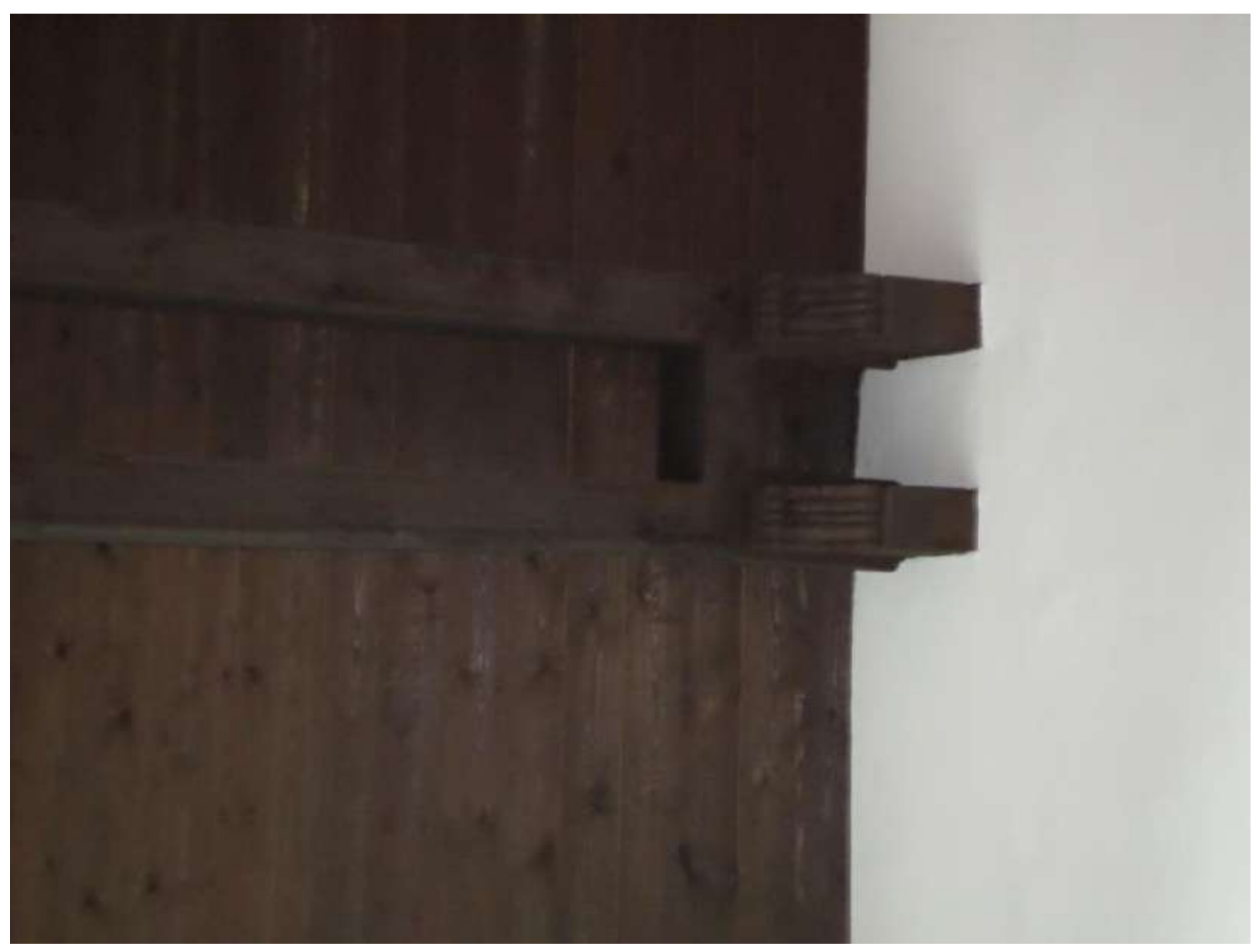

11) Canes lobulares de los tirantes pareados.

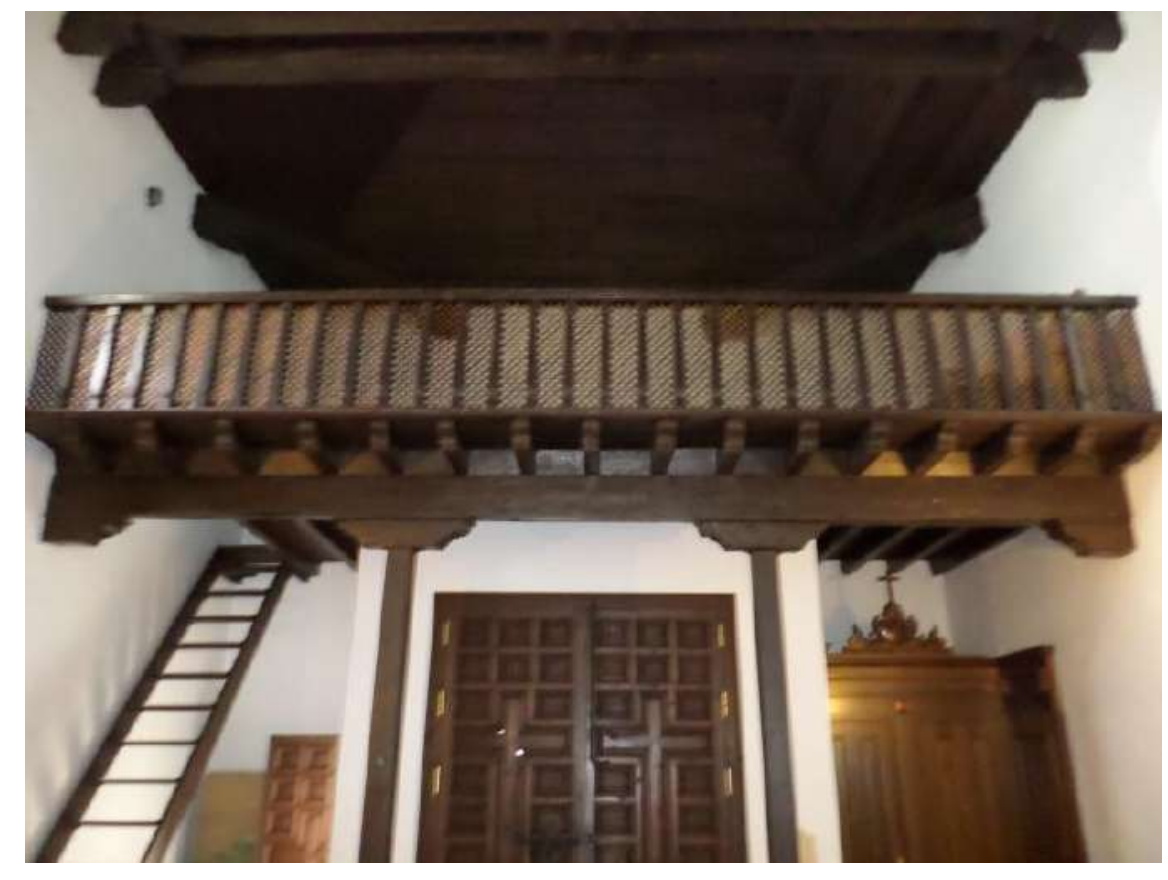

12) Alfarje. 


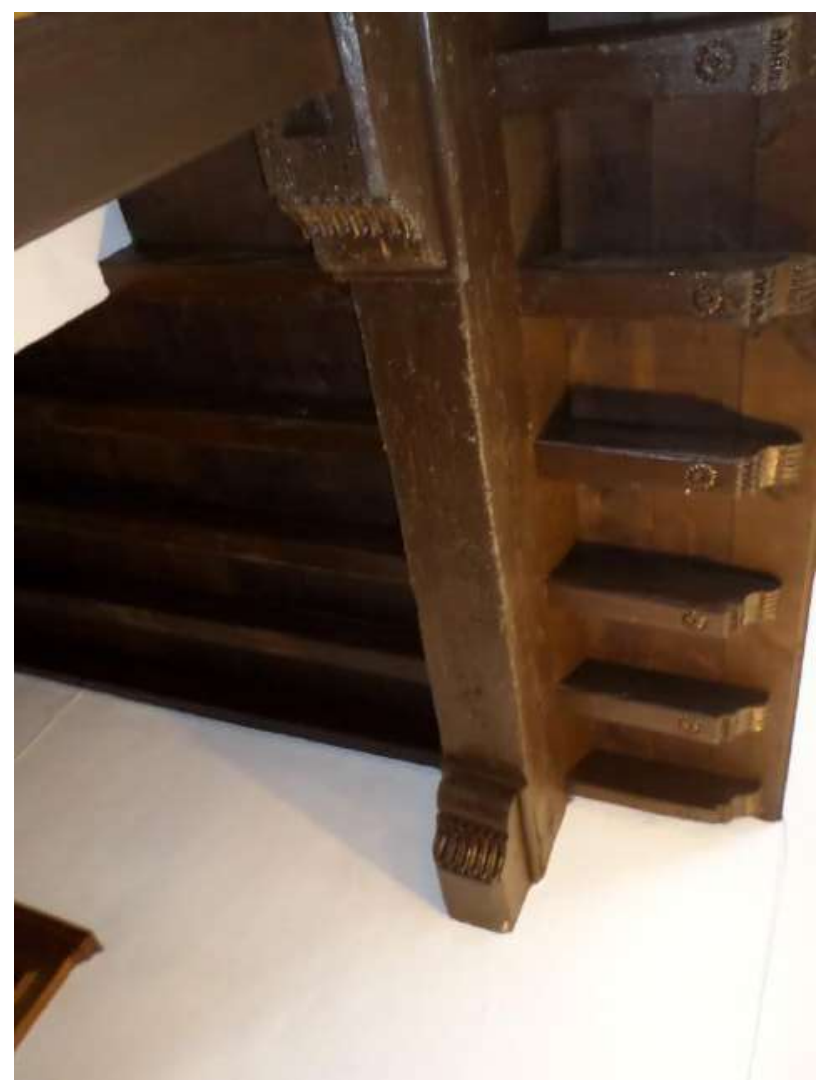

13) Detalle del alfarje en su jácena y jaldetas decoradas en los extremos.

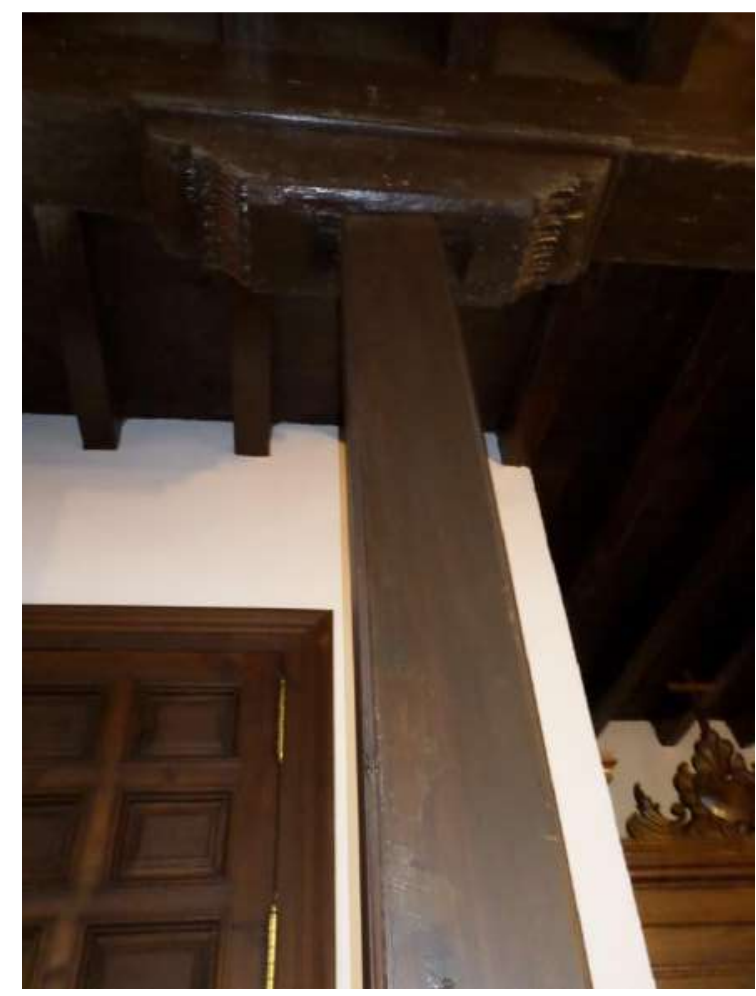

14) Columna que sostiene el alfarje. 
Por último, hemos de comentar la torre. La torre está situada en el lado NO de la iglesia y está construida en cintas de ladrillo y yeso y también está revocada. En el cuerpo superior de la misma se sitúan las campanas en un arco de medio punto sostenido por pilastras dóricas. Este arco a la vez está rodeado por cuatro pilastras dóricas que sostienen una cornisa.

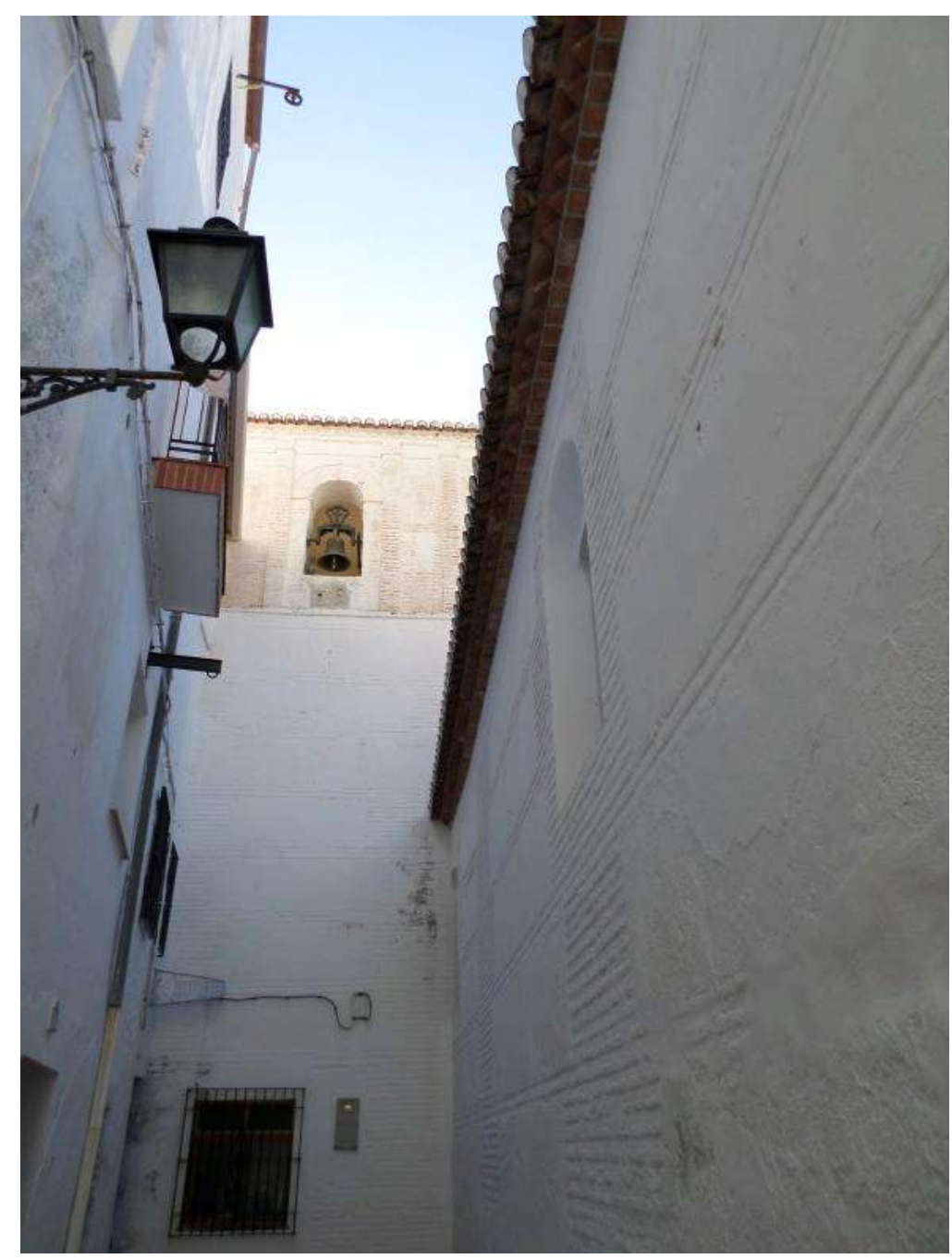

15) Torre. 


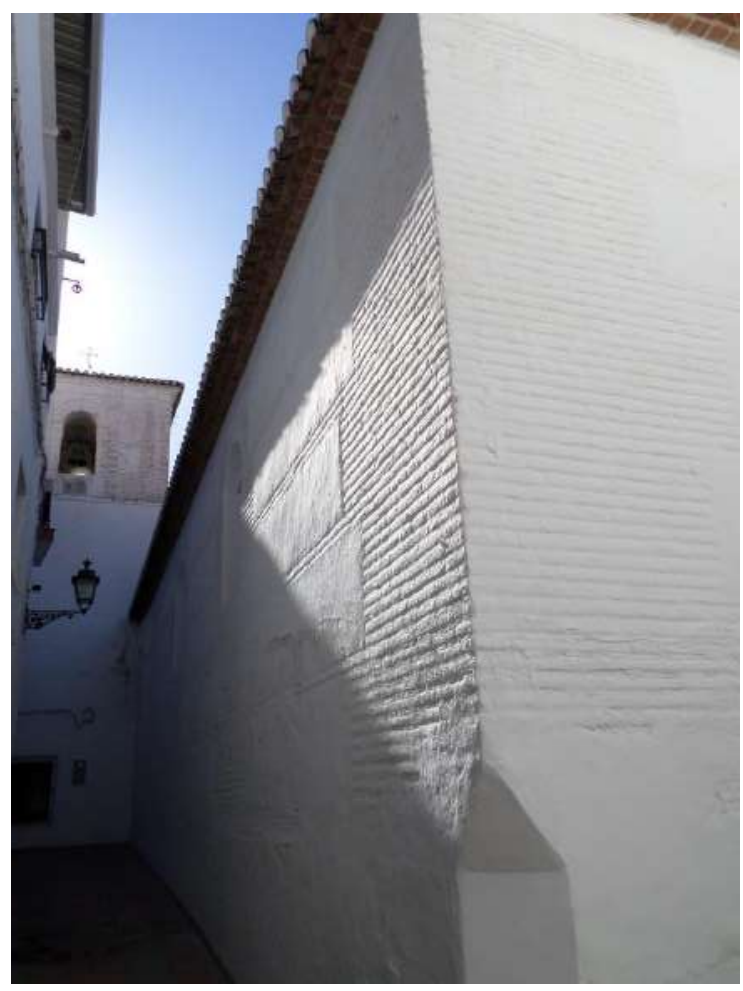

16) Vista de la torre.

De la iglesia que hemos descrito, la parte mudéjar sería, en primer lugar, la predominante estructura espacial. Del espacio exterior, las cintas de ladrillo y yeso que aparecen toda la estructura y en la torre. Los arcos de medio punto del muro derecho, y los arcos con alfiz del muro izquierdo, y como no, la gran portada moderna de ladrillo, que, aunque nueva le da un gran esplendor mudéjar a la iglesia. Del extenso interior, hemos de mencionar como propiamente mudéjar, la reconstruida armadura que imita a la primitiva junto con los tirantes y los cuadrales, y el antiguo alfarje del coro.

\subsection{Iglesia Parroquial de San Antonio de Jete.}

La actual Iglesia Parroquial de San Antonio de Jete es de 1754, construyéndose en el lugar donde se encuentra hoy, pero el primitivo templo se edificó en 1560 junto al cauce del río y destruida por este motivo, construyéndose la nueva más elevada. ${ }^{61}$ Los principales materiales de construcción que se emplearon en la edificación de este nuevo templo son la piedra, el ladrillo, el yeso y la madera.

La antigua iglesia fue realizada por el albañil Francisco Sánchez y el cantero Pedro Solorzano, siendo quemada por los moriscos y reconstruida en 1621 enteramente junto con su armadura. La armadura de la iglesia primitiva era de lima bordón, con

${ }^{61}$ VV.AA. Guía artística de Granada y su.... Op. cit., pág. 175. 
decoración de lazo en los cabos del almizate y con cinco tirantes de lazo de ocho con aspillas. $^{62}$

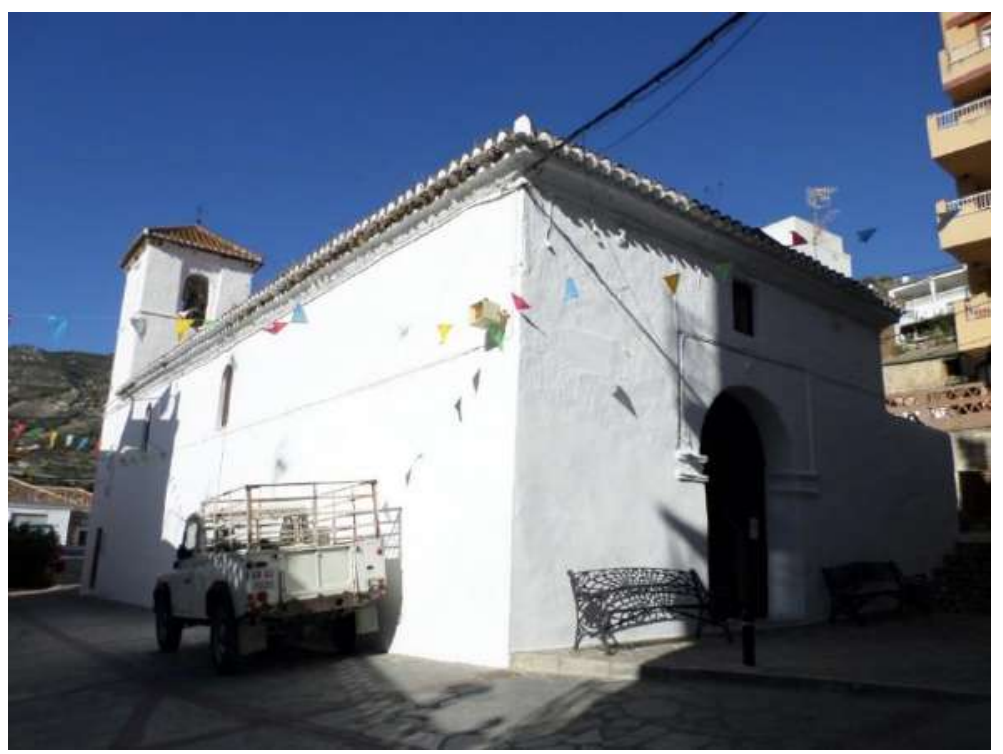

1) Actual Iglesia Parroquial de San Antonio de Jete.

La iglesia actual tiene una nave única rectangular y sin capilla mayor ${ }^{63}$ presentando coro a los pies.

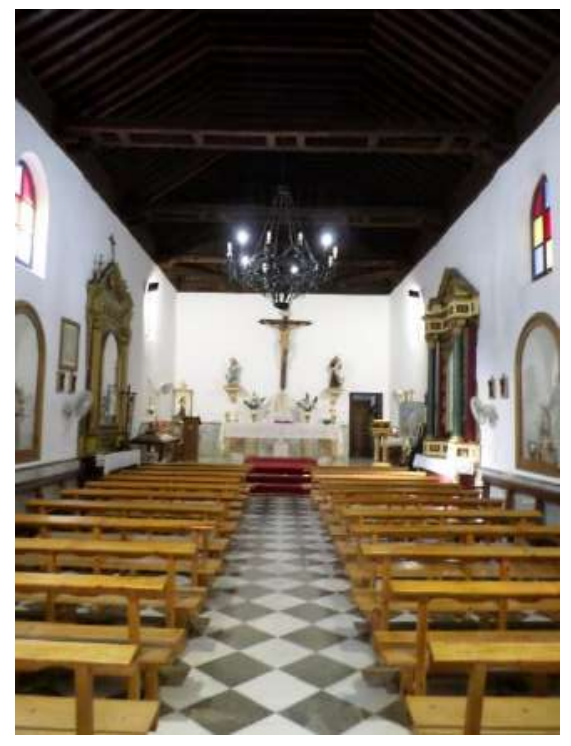

2) Nave de la iglesia.

62 GÓMEZ-MORENO CALERA, J.M. La arquitectura religiosa granadina en la crisis del Renacimiento (1560/1650). Granada: Editorial de la Universidad de Granada, 1989. págs. 332.

${ }^{63}$ Este tipo de planta de nave única rectangular y sin capilla mayor diferenciada, cubierta por una armadura, como se describe más adelante, responde...Op. cit. 


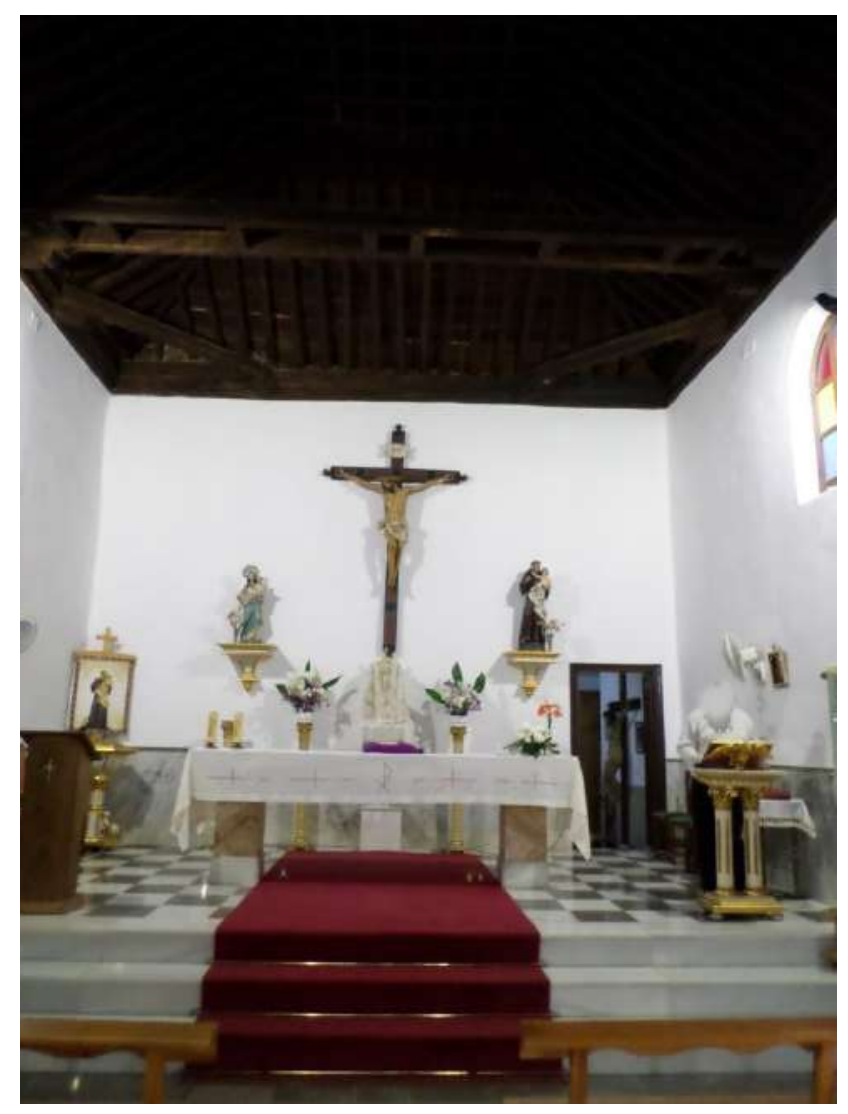

3) Capilla mayor.

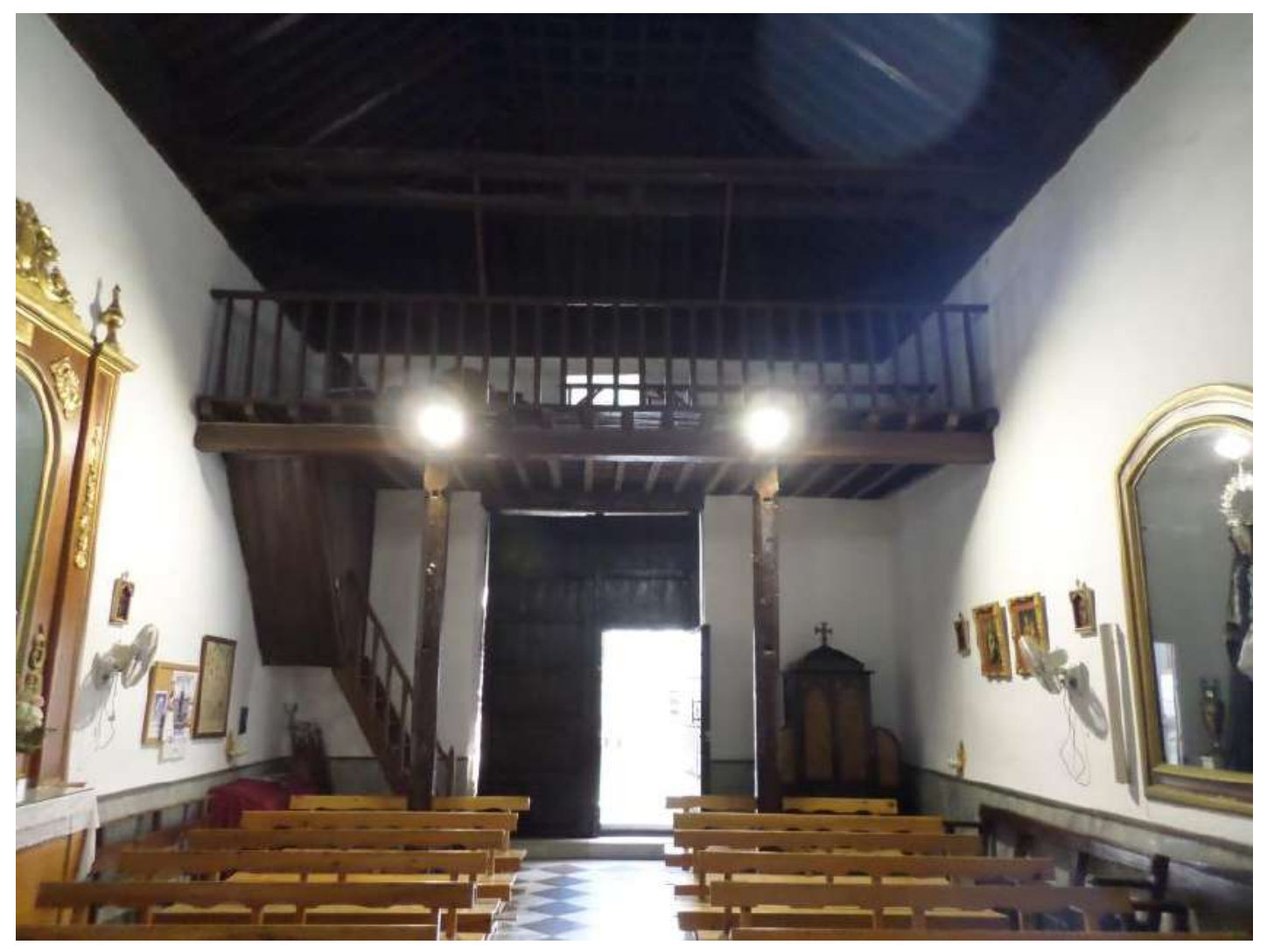

4) Coro. 
En el exterior del templo podemos ver el paso del tiempo ya que todo el exterior está revocado por lo que las cintas de ladrillo y yeso en la que está construida la iglesia no se perciben. Este revoco se añadió después de la Guerra Civil como nos relatan los propios vecinos del pueblo. La fachada principal es muy simple y austera ya que en ella solo hay un arco de medio punto con clave sostenido por dos pilastras con doble capitel dórico rodeado por un sencillo alfiz que enmarca la puerta principal de acceso al templo, estando todo coronado por un vano adintelado. Este arco es de ladrillo, pero también fue revocado después de la Guerra Civil, como nos han relatado los vecinos.

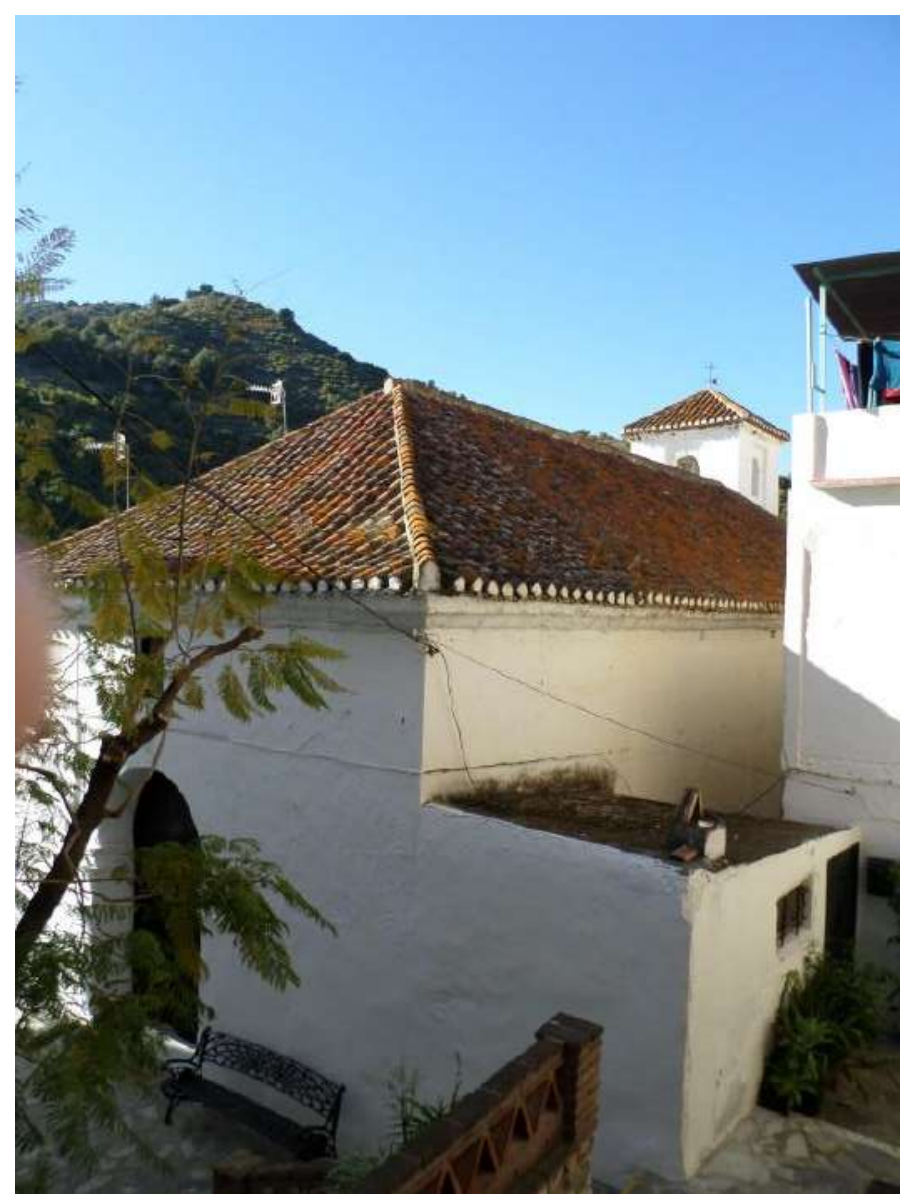

5) Lateral derecho de la iglesia con fachada. 


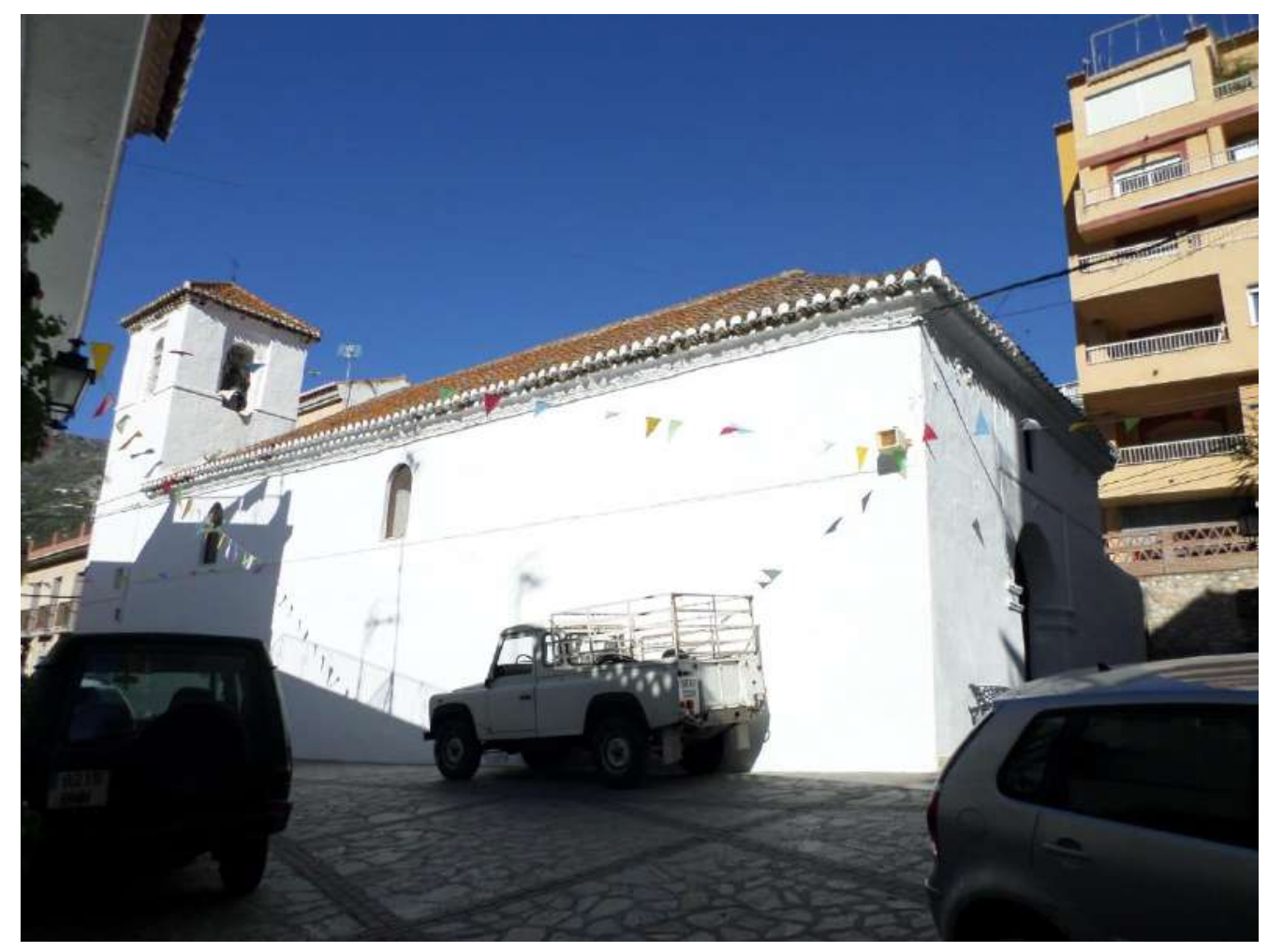

6) Lateral izquierdo de la iglesia.

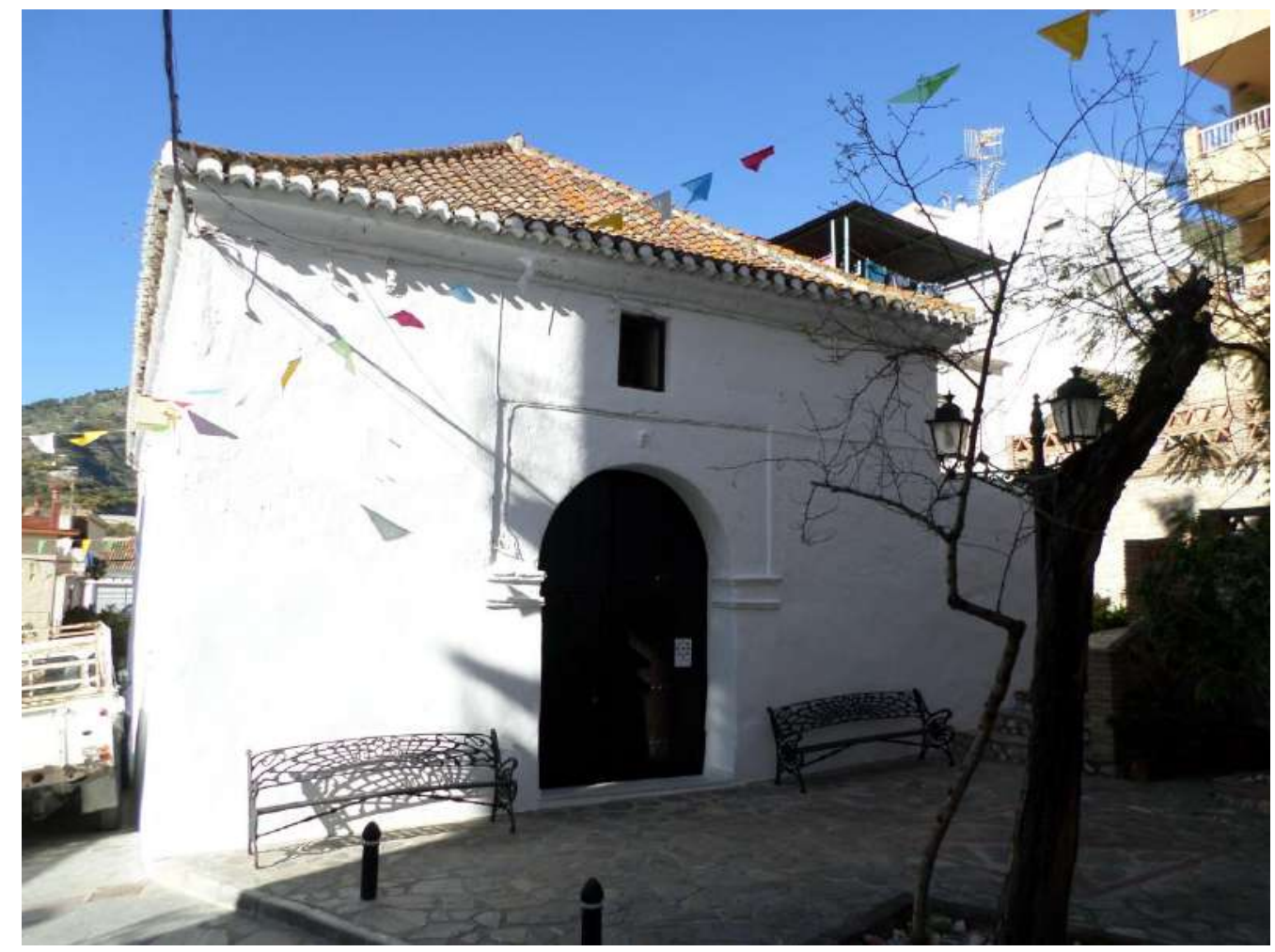

7) Fachada principal. 


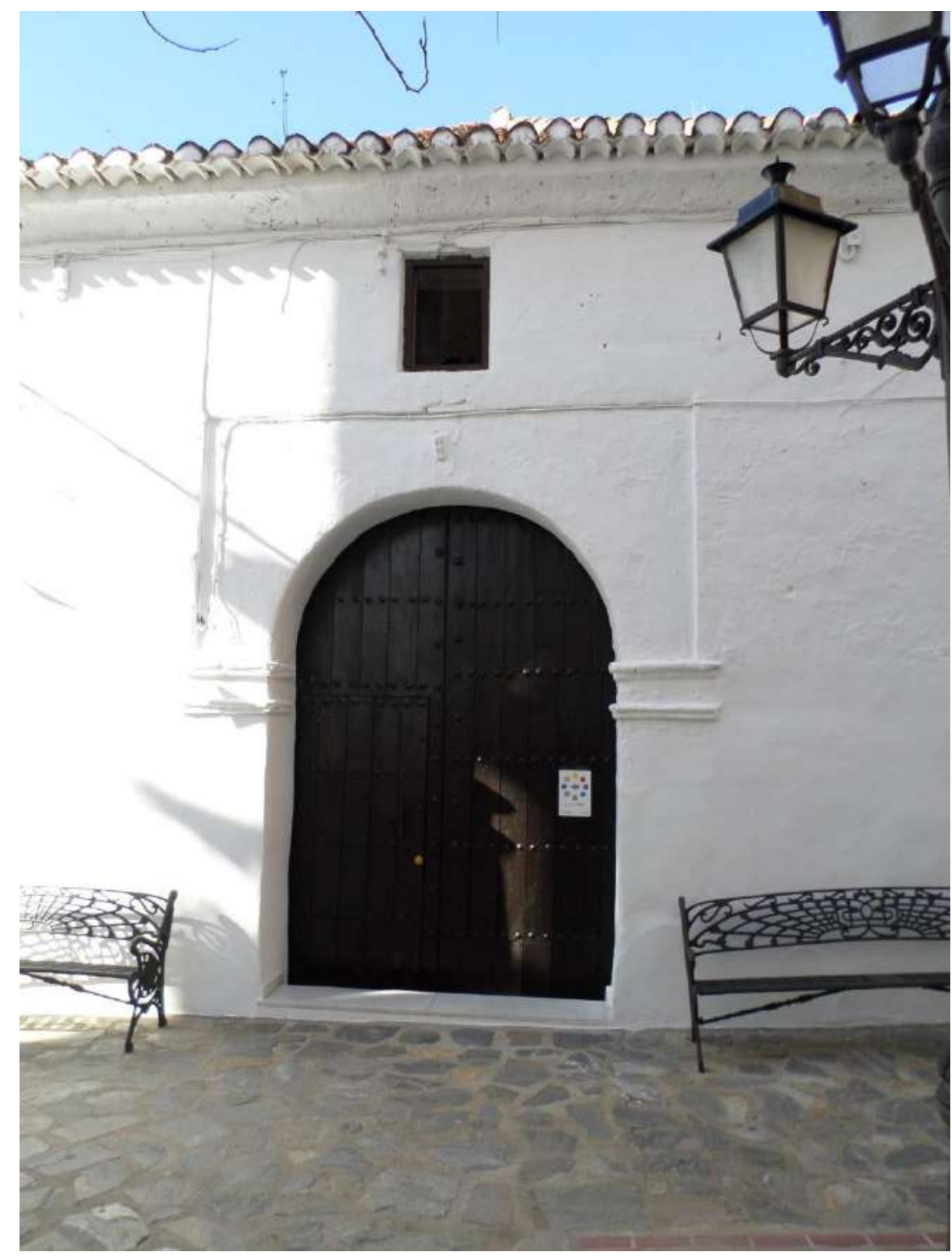

8) Portada de la fachada principal.

En el interior, hemos de describir que los muros son enormemente gruesos y cumplen la función de cerramiento del edificio y de descarga del peso de los elementos superiores, a la vez que dan gran sensación de solidez. El muro lateral izquierdo presenta dos vanos de arcos de medio punto que iluminan interiormente la nave de la iglesia. Esta nave está cubierta por una armadura de lima bordón que tiene tirantes pareados sostenidos por canes lobulados, presenta también cuadrales con canes lobulados. Los pares de la armadura no tienen decoración, y tiene almizate, pero hemos de destacar que en los extremos de este almizate hay decoración de retícula, algo que podemos sospechar que puede haberse perdido el del resto del almizate. El coro está sostenido por un alfarje, compuesto por una jácena sin canes que sostiene diecisiete jaldetas que sobresalen por la jácena, sobre estas jaldetas se colocan las tablazones que 
no tienen ningún tipo de decoración. Este alfarje está sostenido por dos columnas de madera que se apoyan en la jácena, y en la parte derecha hay una gran estructura de manera que pertenece al huevo de la escalera que da acceso al coro.

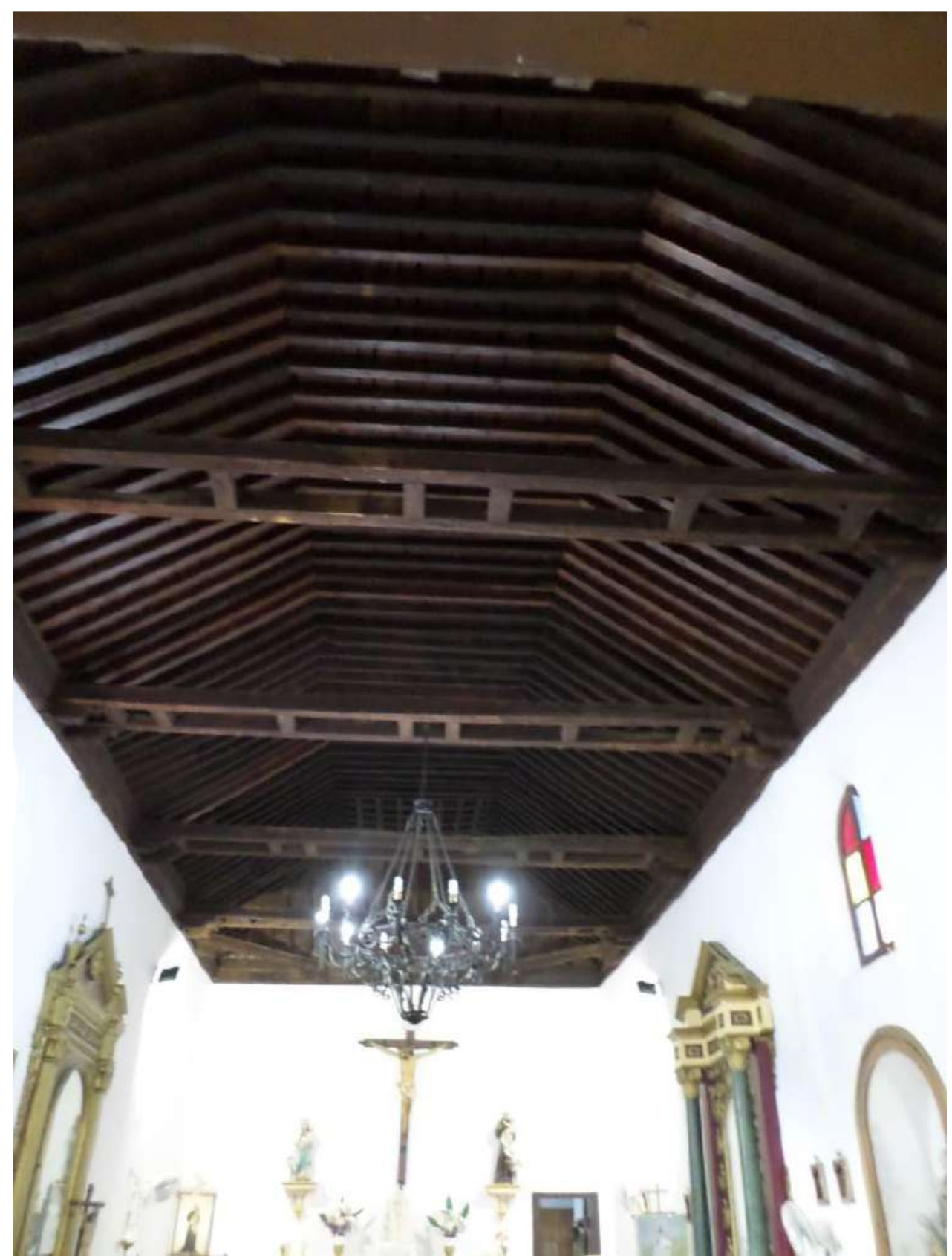

9) Armadura de la nave de la iglesia. 


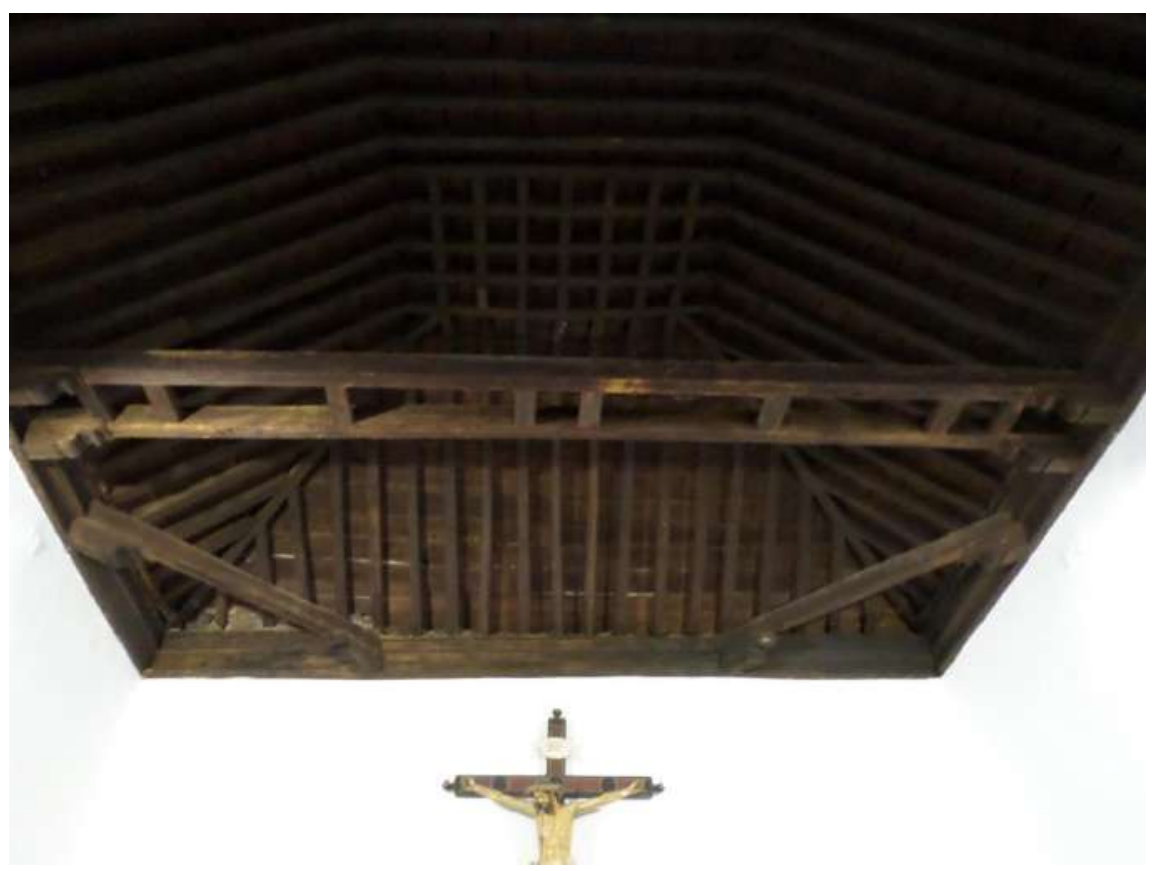

10) Detalle de armadura de la nave de la iglesia.

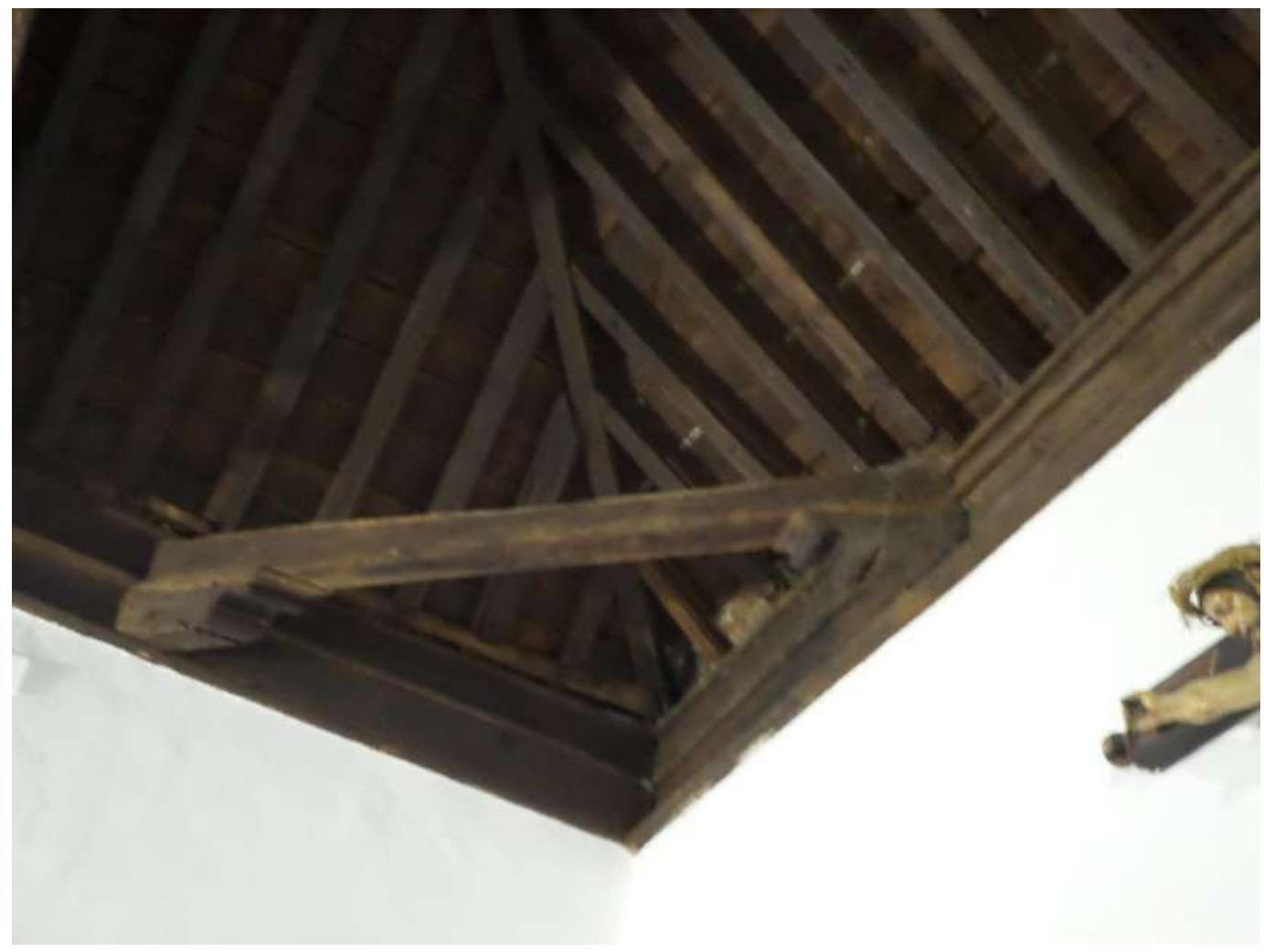

11) Cuadral con canes lobulares de la armadura de la nave de la iglesia. 


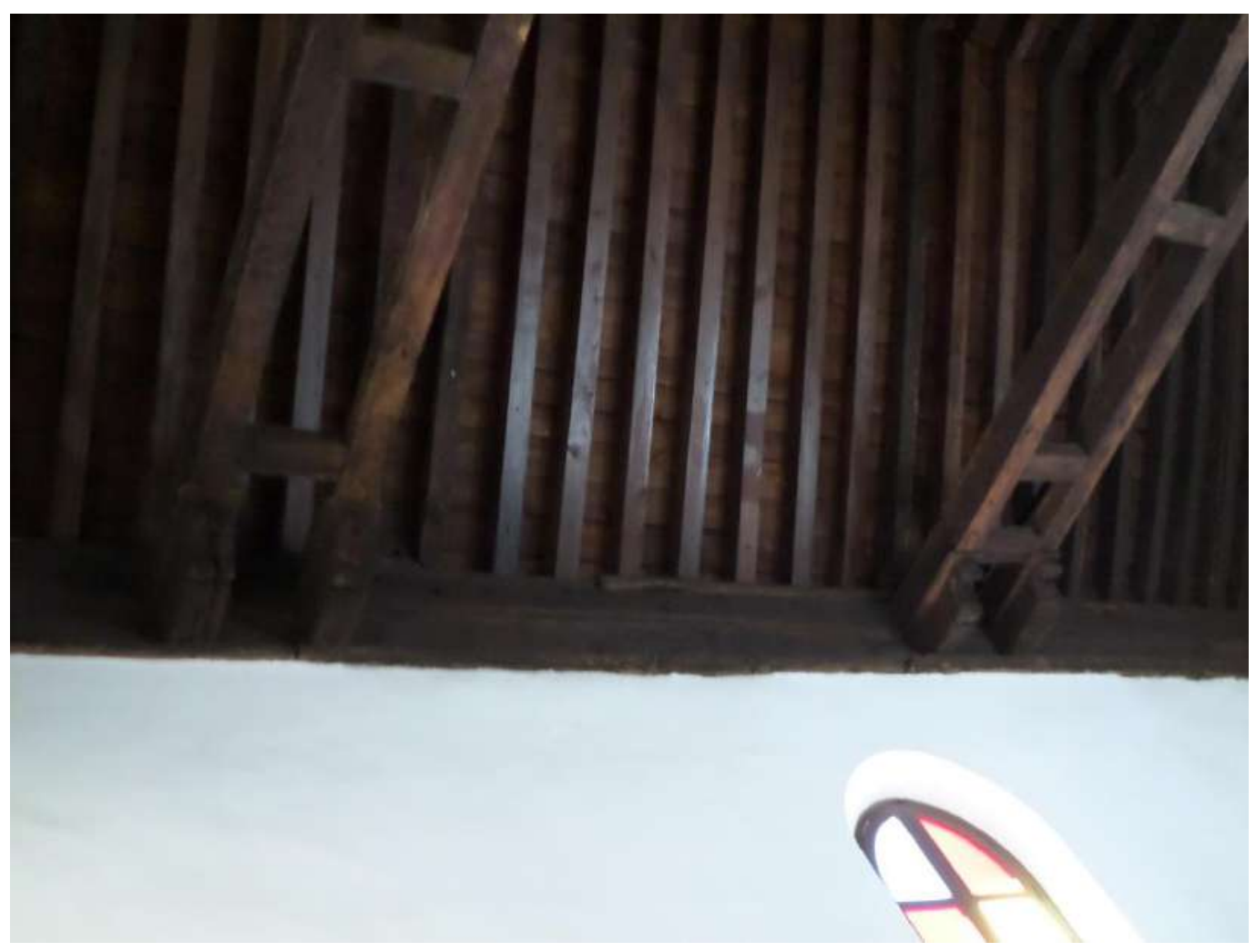

12) Canes lobulados de los tirantes pareados.

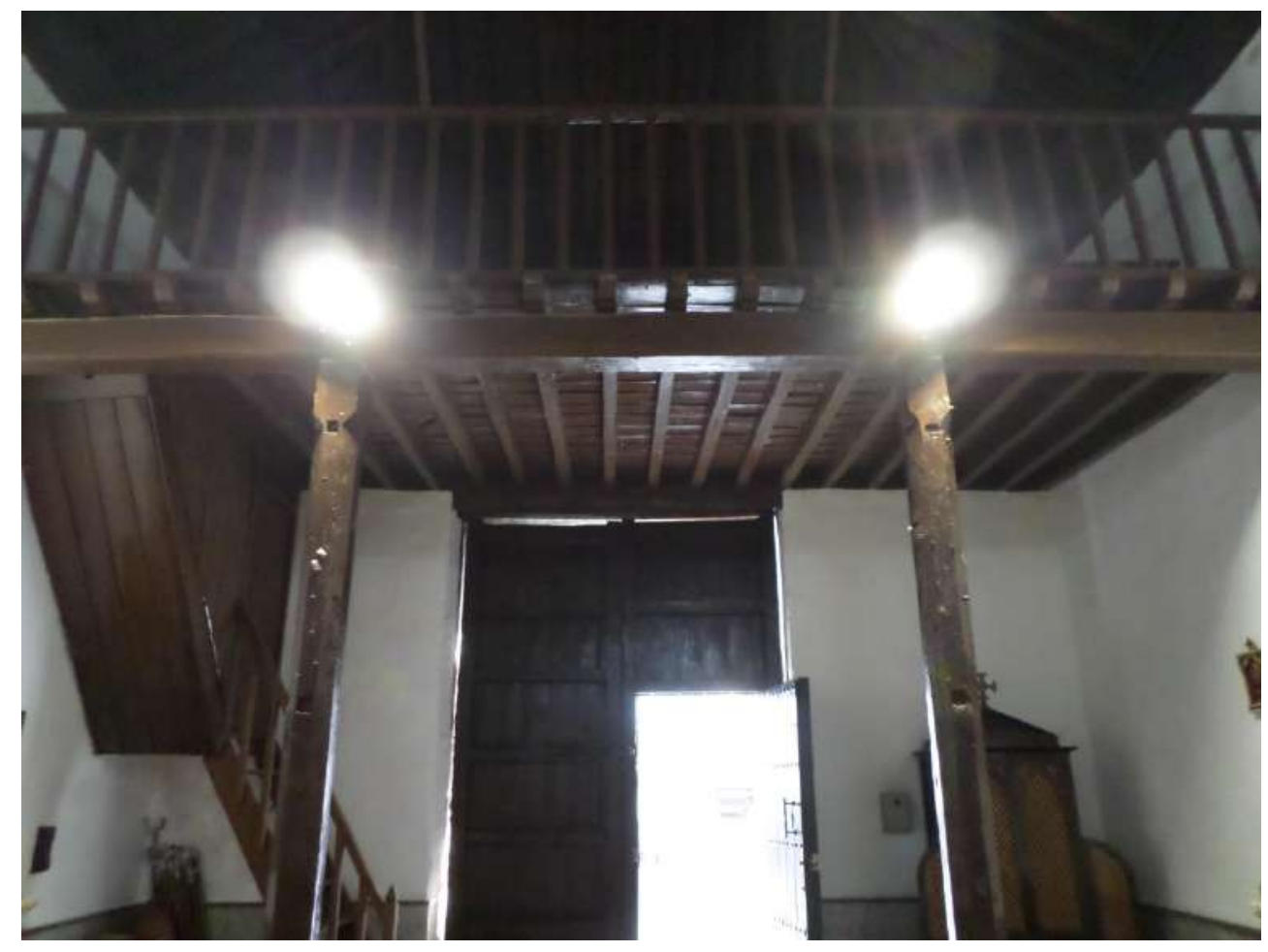

13) Alfarje. 


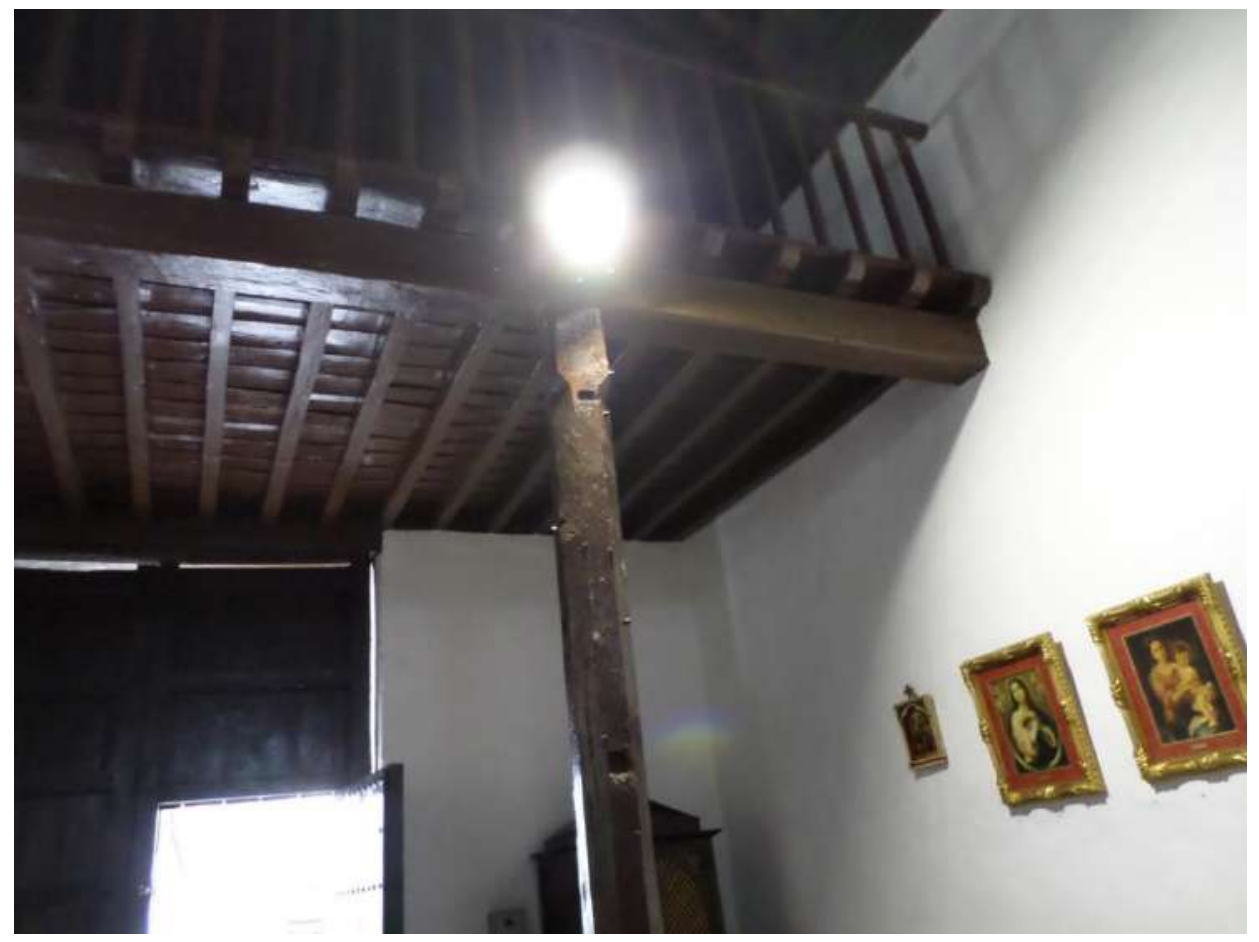

14) Detalle del alfarje.

Por último, se ha describir la torre que está situada en el lado NO de la iglesia y está construida en cintas de ladrillo y yeso y también está revocada. Esta torre presenta tres cuerpos. El último cuerpo tiene un arco de medio punto en sus cuatro lados enmarcados en un paño rehundido donde se sitúan las campanas.

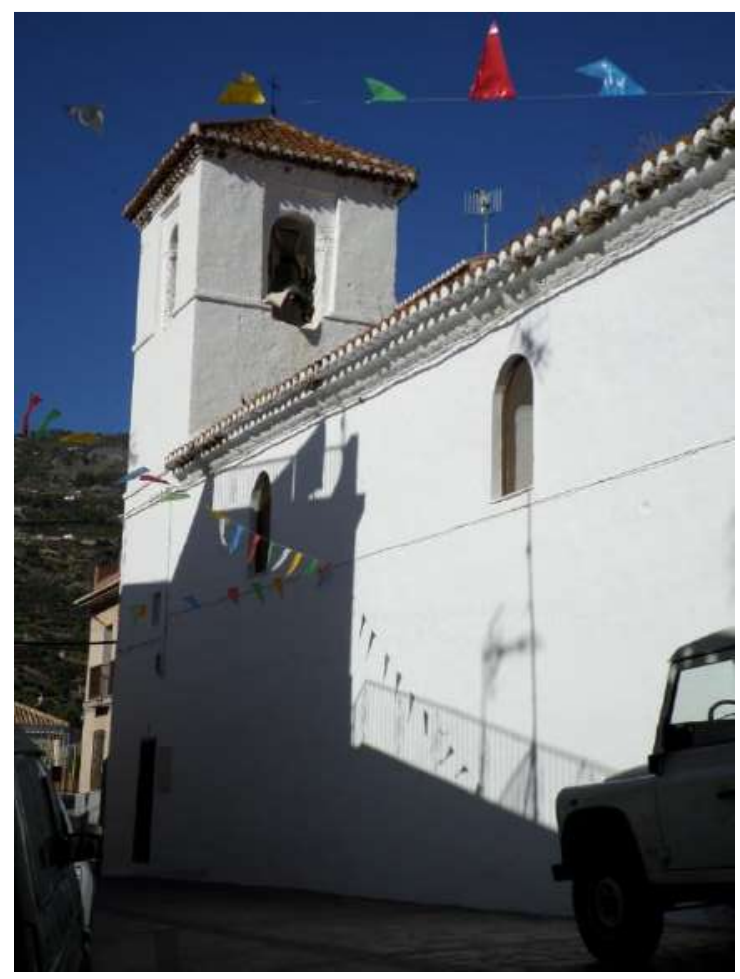

15) Vista de la torre. 


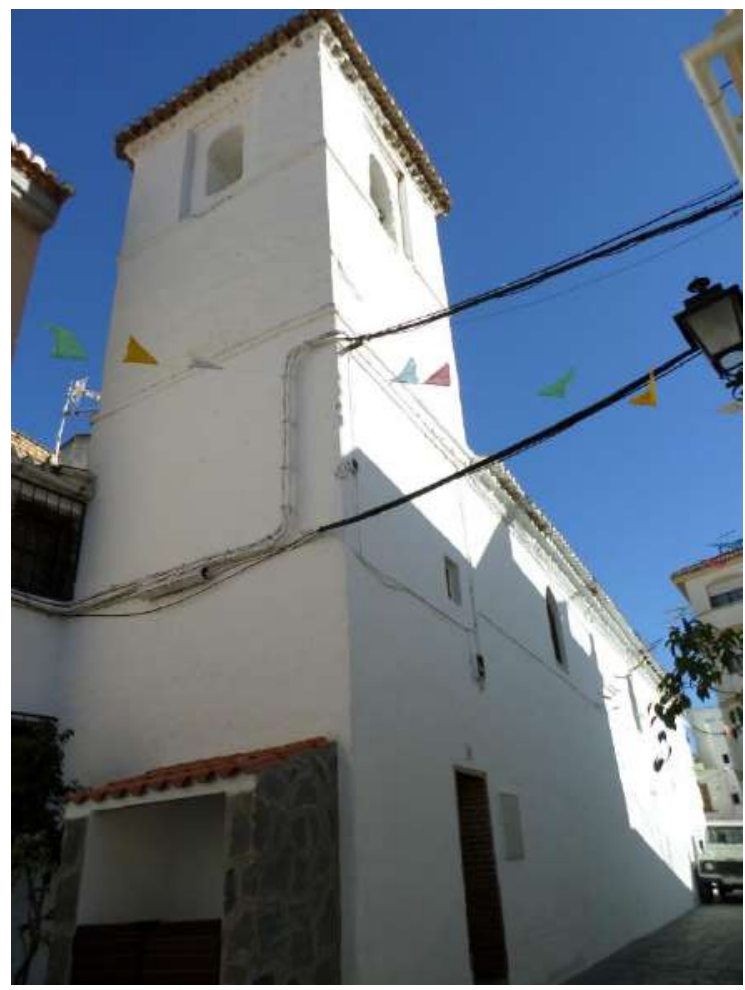

16) Torre.

De la iglesia que hemos descrito, la parte mudéjar sería, en primer lugar, la predominante estructura espacial. Del exterior, las grandes cintas de yeso y ladrillo que hay en todas las fachadas y en la torre, aunque estén revocadas. El gran arco de medio punto rodeado por un alfiz de la fachada principal que ha perdido toda su decoración y que no se ve el material original. Del interior de única nave, hemos de destacar como mudéjar, la gran armadura y el antiguo alfarje del coro.

\subsection{Iglesia de Nuestra Señora del Rosario de Salobreña.}

La primitiva iglesia de Nuestra Señora del Rosario de Salobreña se construyó en $1513^{64}$ según un plan gótico mudéjar, quedando casi irreconocible a causa de un incendio que sufrió en 1821. La reconstrucción de la iglesia tras este incendio estuvo a cargo de José Contreras en 1832. ${ }^{65}$ Los materiales de construcción del templo son la piedra, el ladrillo, el yeso, el azulejo y la madera, siendo así que las cintas de yeso y ladrillo y los cajones de mampostería del exterior están revocados únicamente en las fachadas.

${ }^{64}$ PAREJA LÓPEZ, Enrique y MEGÍA NAVARRO, Matilde. Salobreña. Datos para su historia. Granada: Diputación de Granada, 1978., págs.. 132-136.

${ }^{65}$ VV.AA. Guía artística de Granada y su.... Op. cit., pág. 187. 


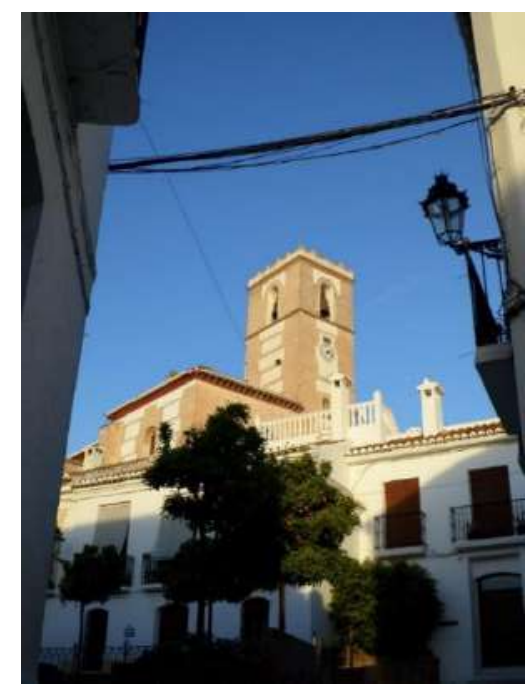

1) Vista de la iglesia de Nuestra Señora del Rosario de Salobreña.

La iglesia tiene tres naves separadas por tres arcos apuntados y capilla mayor diferenciada. ${ }^{66}$ La nave central, que tiene coro a los pies, es más alta y ancha que las laterales, y por medio de ella se accede a la capilla mayor cuadrada a través de un arco toral apuntado sostenido por pilares dóricos. Por la capilla mayor se accede a la sacristía y a la torre.

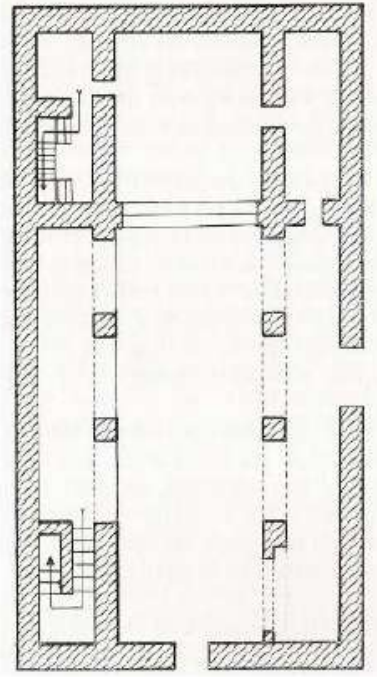

2) Plano de la iglesia. ${ }^{67}$

${ }^{66}$ Este tipo de planta de tres naves separadas por arcos y capilla mayor diferenciada, en cuya nave central estaría una armadura de limas, según el esquema de iglesia que observamos, y en las laterales armaduras de colgadizo, con una capilla mayor cubierta por bóveda ochavada, como bien se describe más adelante, responde a las tipologías de planta de iglesias mudéjares de Granada según el estudio realizado por Don Rafael López Guzmán:

- LÓPEZ GUZMÁN, Rafael. Arquitectura...Op. cit., pág.396.

${ }^{67}$ MARTÍN GARCÍA, Mariano. "Iglesias Fortificadas.... Op. cit., pág. 733. 


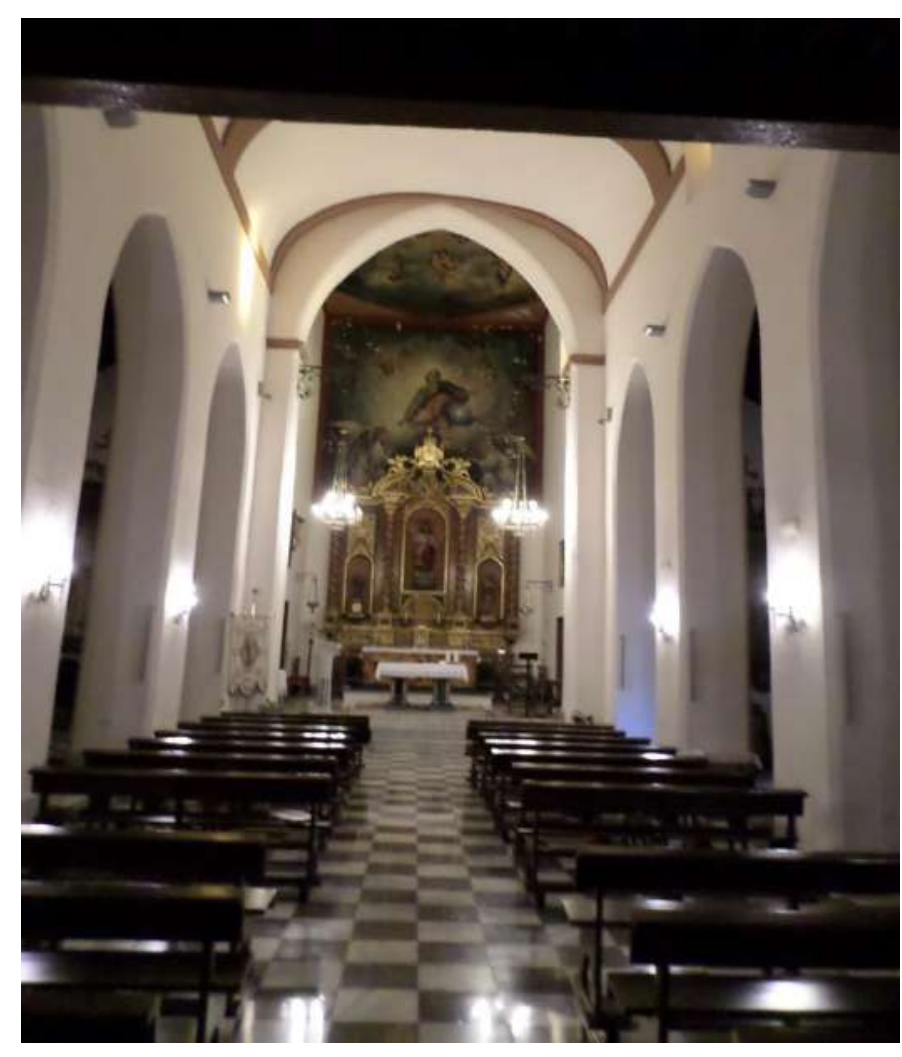

3) Nave central de la iglesia.

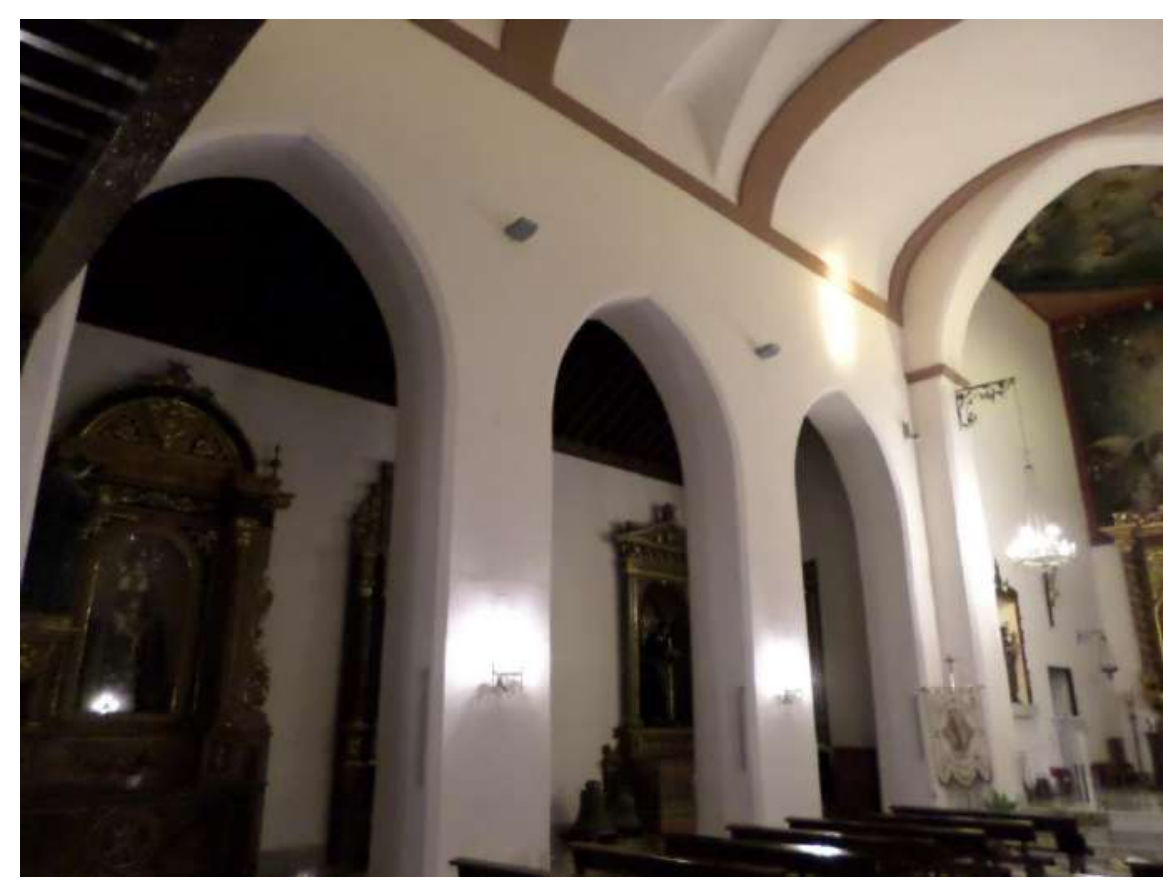

4) Arcos laterales de la izquierda. 


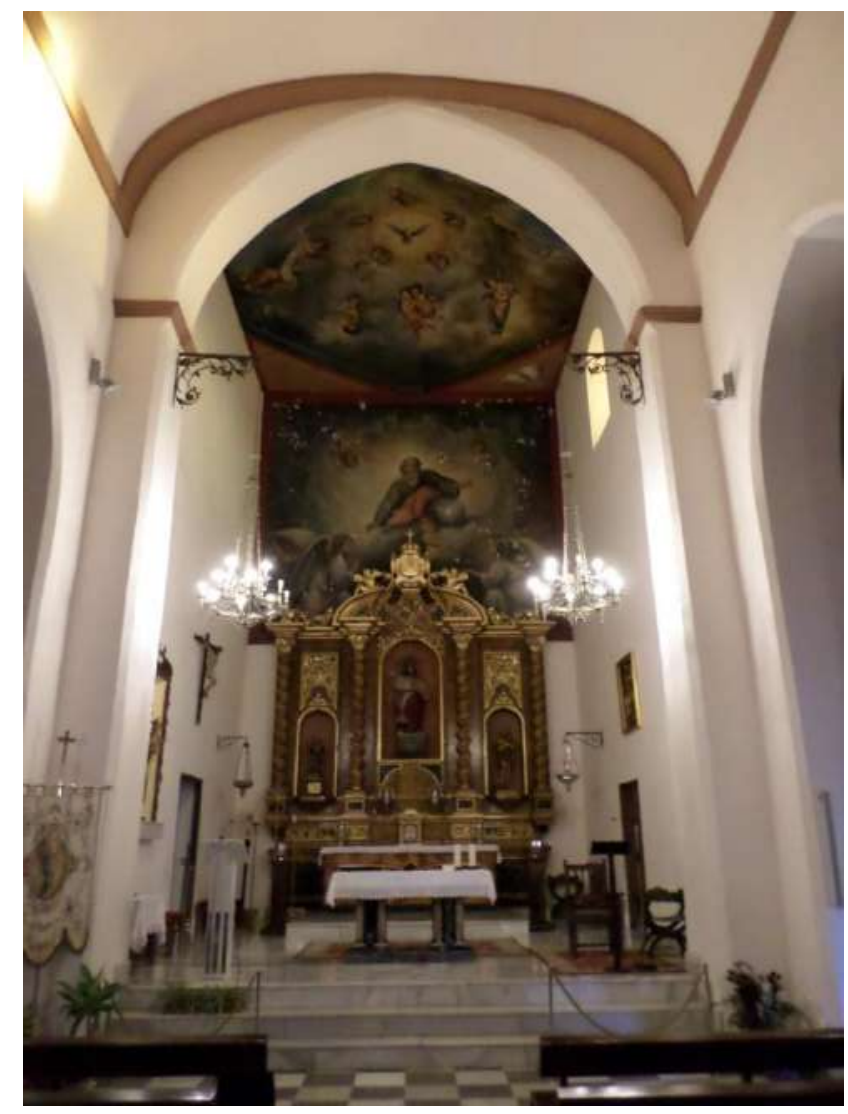

5) Arco toral y capilla mayor.

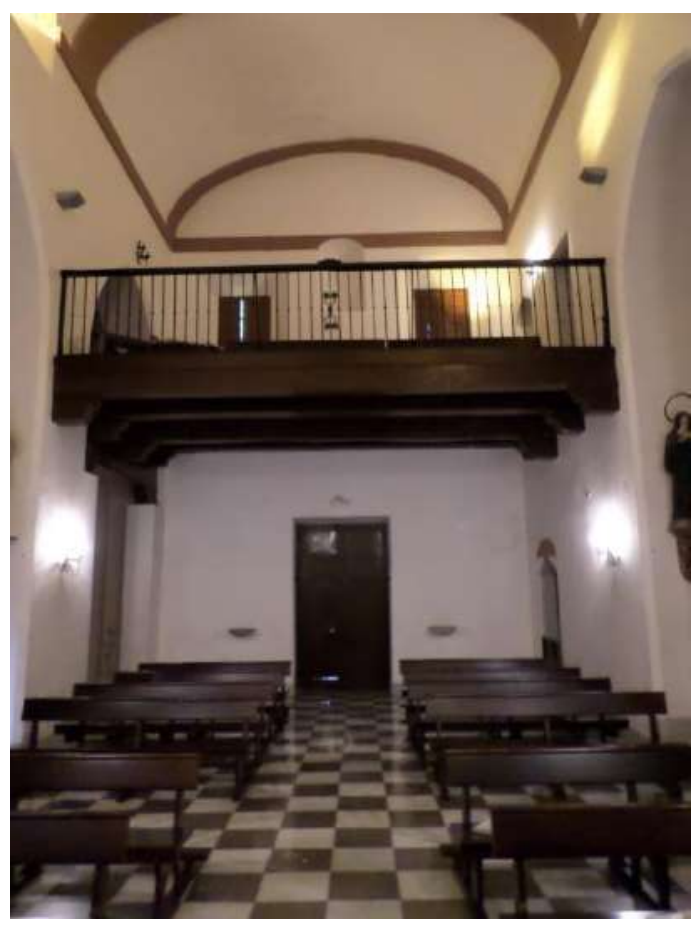

6) Coro. 
En el exterior podemos observar la configuración interna de las tres naves de la iglesia ya que tanto por el lado derecho e izquierdo de la iglesia vemos la diferencia de altura de las naves, siendo las laterales más bajas que la nave central. En el exterior de la nave central y la capilla mayor se perciben las cintas de ladrillo y yeso.

Vislumbramos también que la iglesia tiene dos portadas, la portada sur, que es la principal, y la portada este. La portada principal es adintelada y ella tiene la puerta principal de acceso al templo con dos vanos adintelados que iluminan interiormente la iglesia. Esta fachada es de $1884 .{ }^{68}$ La portada este está formada por un doble arco carpanel enmarcado por un arco conopial sostenidos por columnas dóricas y rodeados por un alfiz, fabricado todo en ladrillo y revocado pintado en granate. El alfiz contiene albanegas con azulejos. Esta portada este es también del s. XIX. ${ }^{69}$

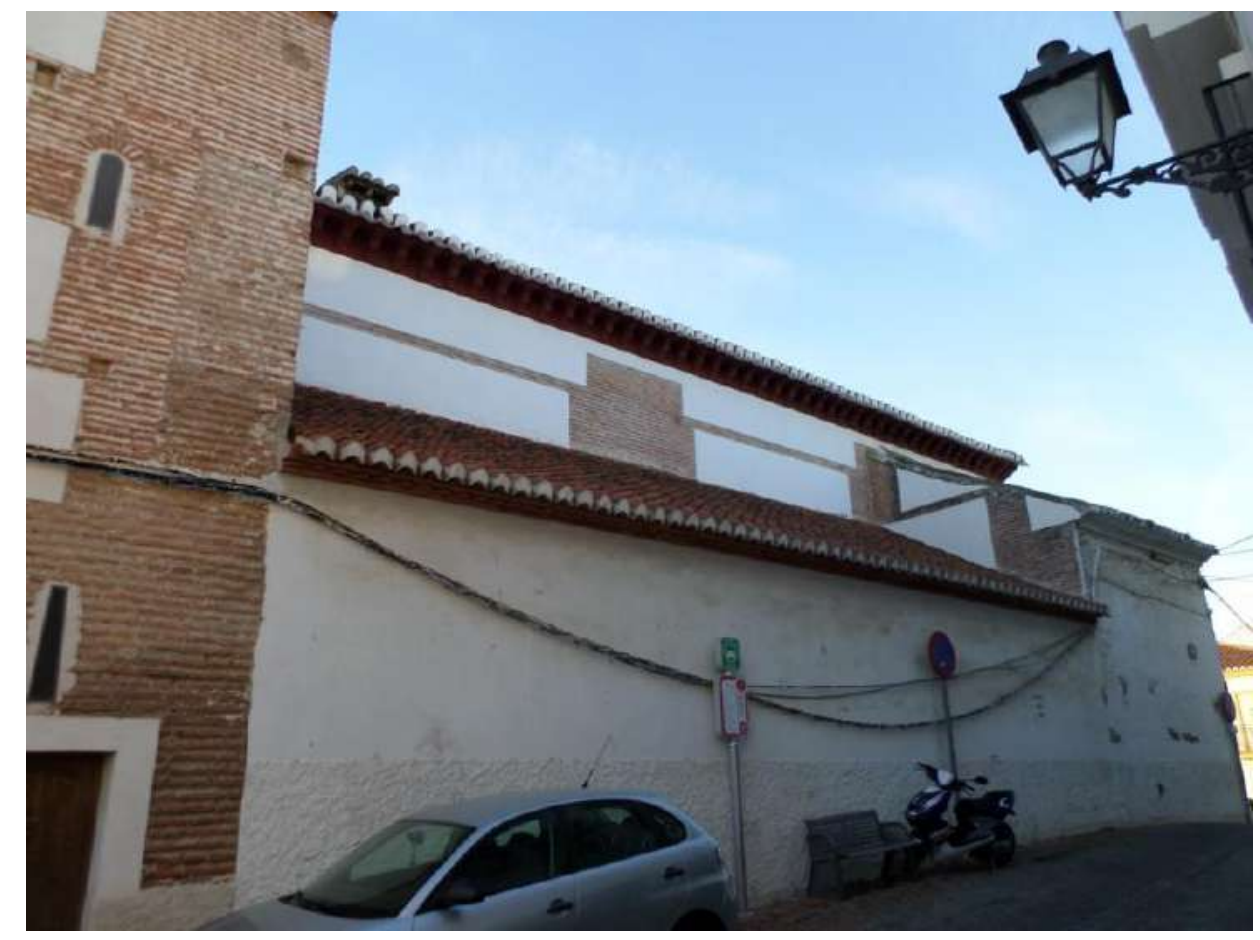

7) Zona exterior izquierda. ${ }^{70}$

${ }^{68}$ VV.AA. Guía artística de Granada y su.... Op. cit., pág. 187.

${ }^{69}$ Ibídem., pág. 187.

${ }^{70}$ En esta foto observamos claramente la diferencia de altura de las naves laterales con respecto a la nave principal o central, en este caso del lateral izquierdo de la iglesia. 


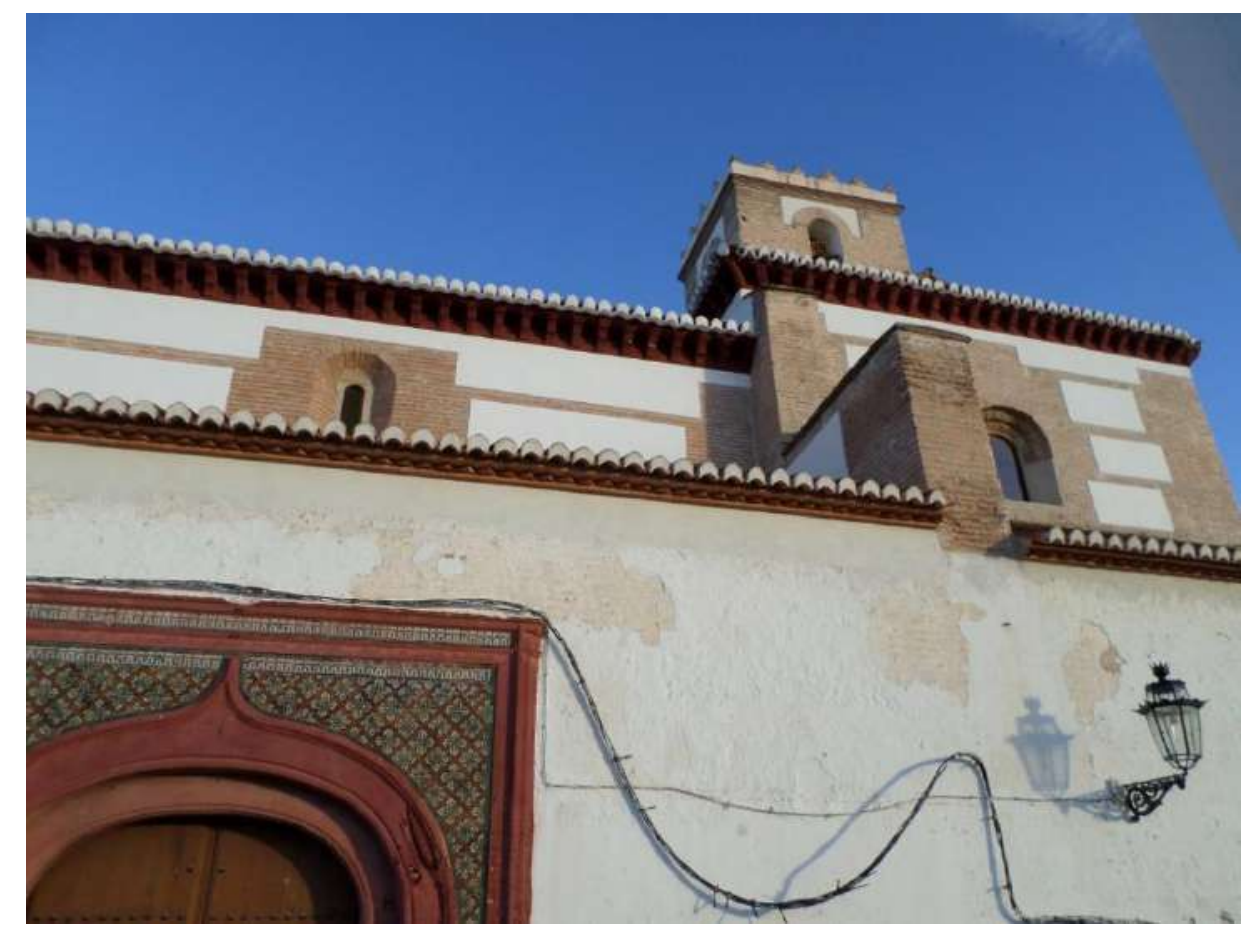

8) Zona exterior derecha. ${ }^{71}$

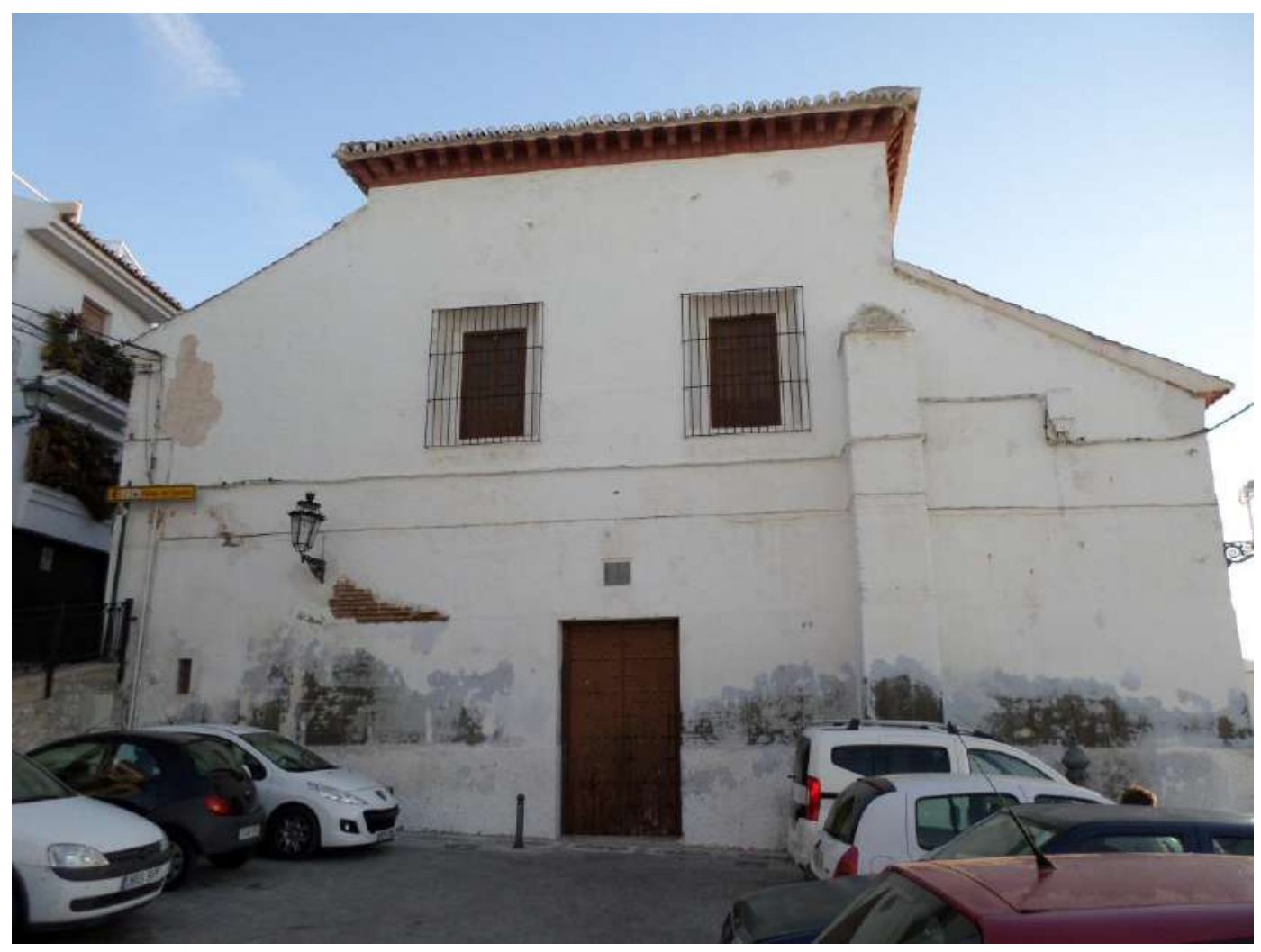

9) Fachada sur.

${ }^{71}$ En esta foto observamos lo mismo que en la anterior, pero en este caso en la zona del lateral derecho de la iglesia. 


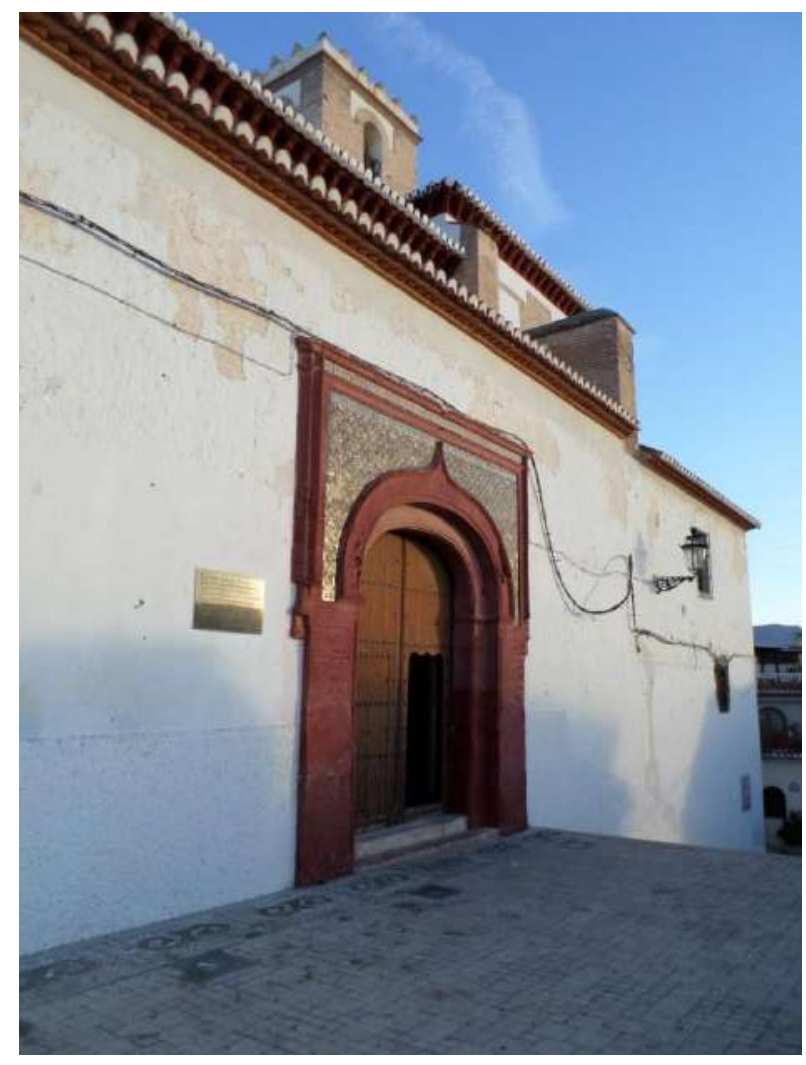

10) Vista fachada este.

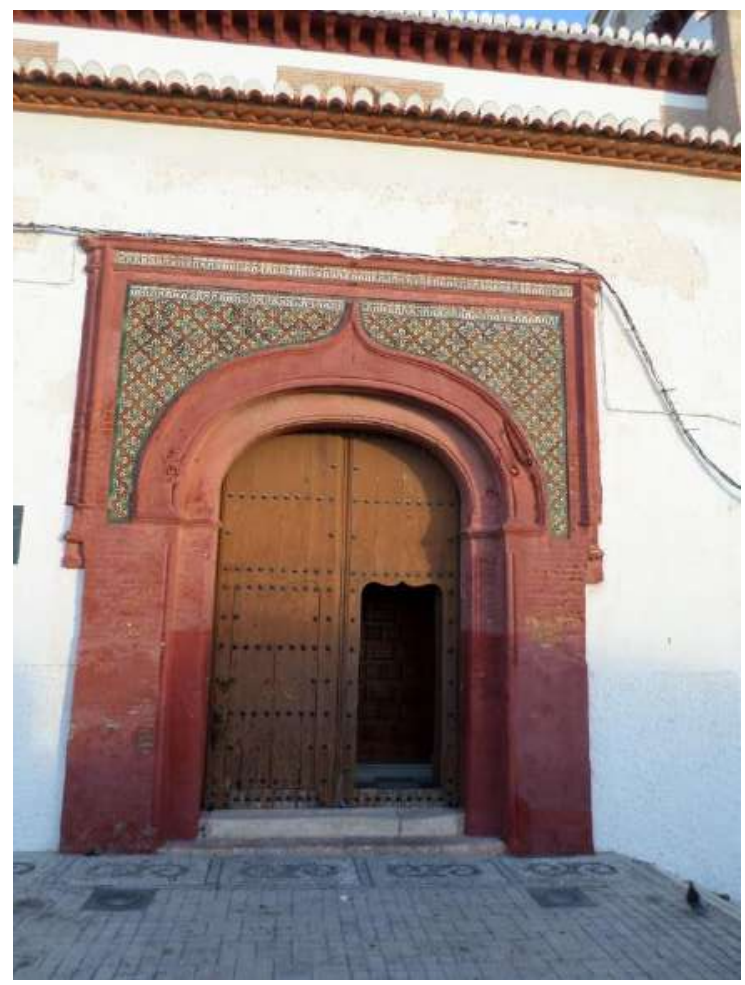

11) Portada Este. 
En el interior, hay que indicar que los muros son gruesos y cumplen la función de cerramiento y sustento del peso de los elementos superiores y dan gran sensación de solidez. El muro derecho de la nave central presenta dos vanos de arcos de medio punto que iluminan dicha nave y el muro izquierdo de la capilla mayor tiene un vano de arco de medio punto que la ilumina también. La nave central actualmente está cubierta por una bóveda de cañón con arcos fajones que descansan en una cornisa, pero según hemos podido conocer por testimonios vecinales, dicha nave estaba cubierta por una armadura que desapareció en el incendio de $1821 .{ }^{72}$ Las naves laterales están cubiertas por armaduras de colgadizo en las que no hay ningún tipo de decoración en los pares. El coro está sostenido por un alfarje formado por cuatro jácenas sostenidas por canes lobulados en diferente disposición los lóbulos. Hay que indicar que otra jácena de iguales características se encuentra situada en el muro lateral derecho sosteniendo a tres de ellas que sustentan la estructura del alfarje. Este alfarje está formado por veintidós jaldetas que no tienen ninguna decoración y donde se colocan las tablazones las cuales tampoco contienen decoración. La capilla mayor está cubierta por una bóveda ochavada en la que aparece una pintura al fresco.

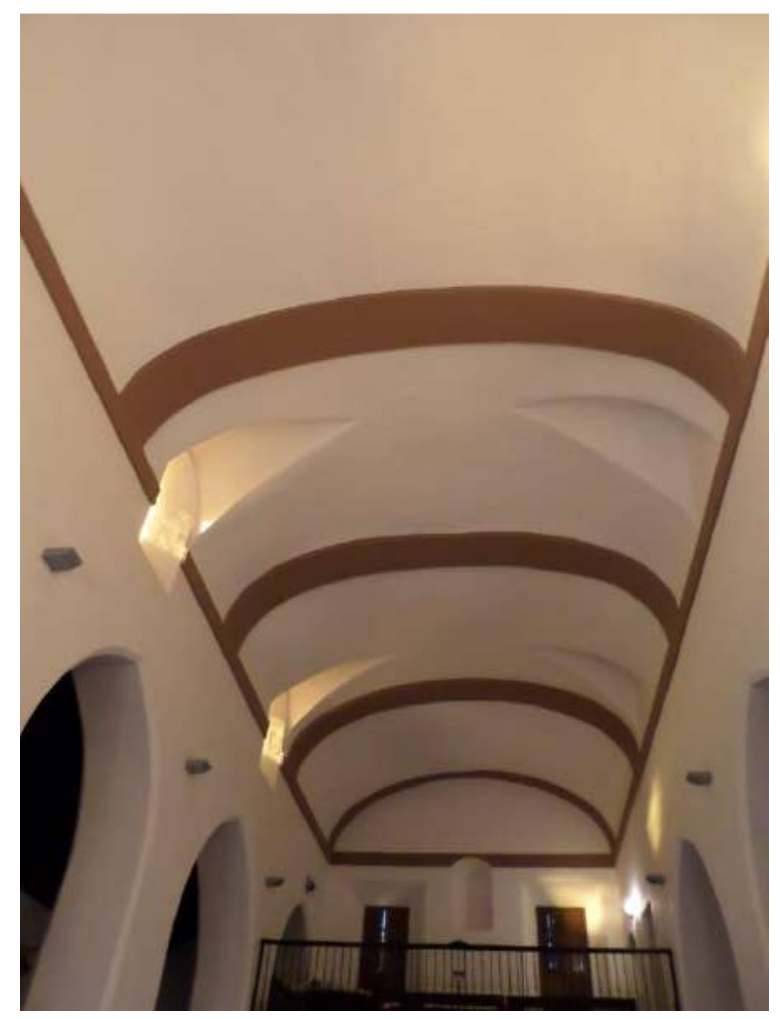

12) Bóveda de la nave central.

\footnotetext{
${ }^{72}$ No tenemos detalles de la armadura de la nave central.
} 


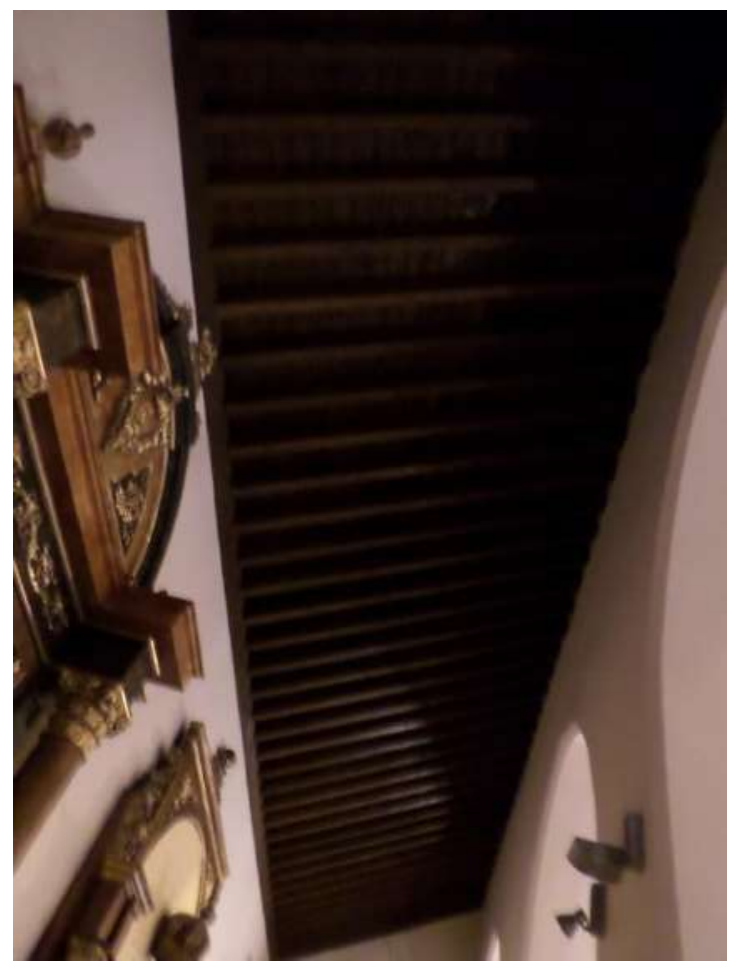

13) Armadura de la nave lateral izquierda.

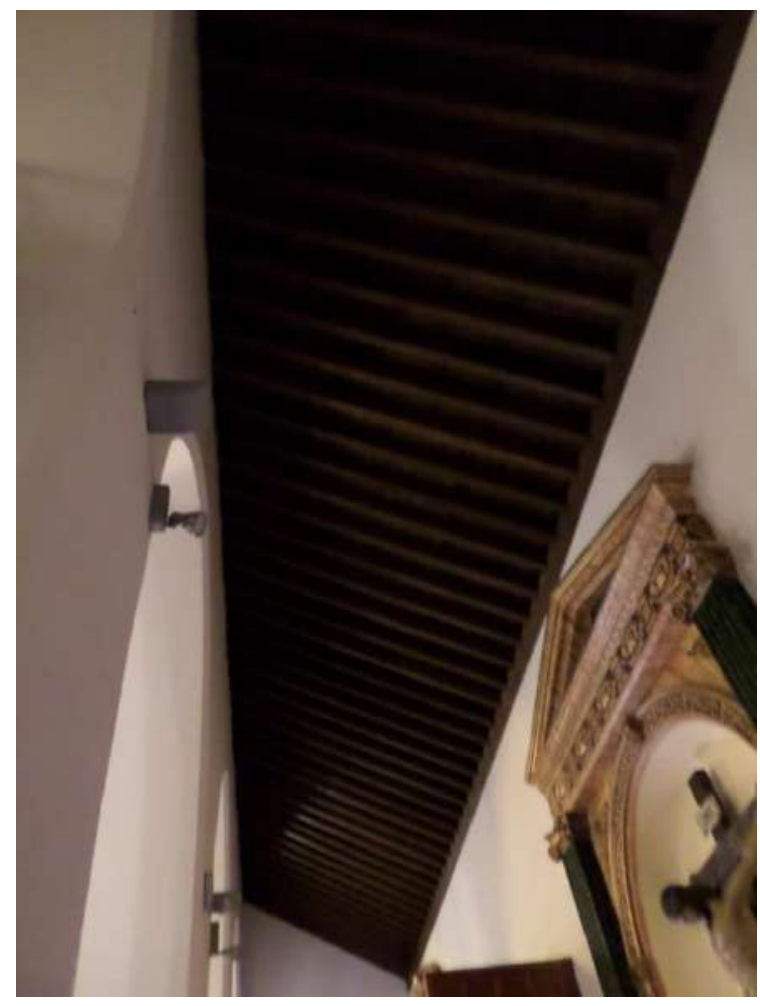

14) Armadura de la nave lateral derecha. 


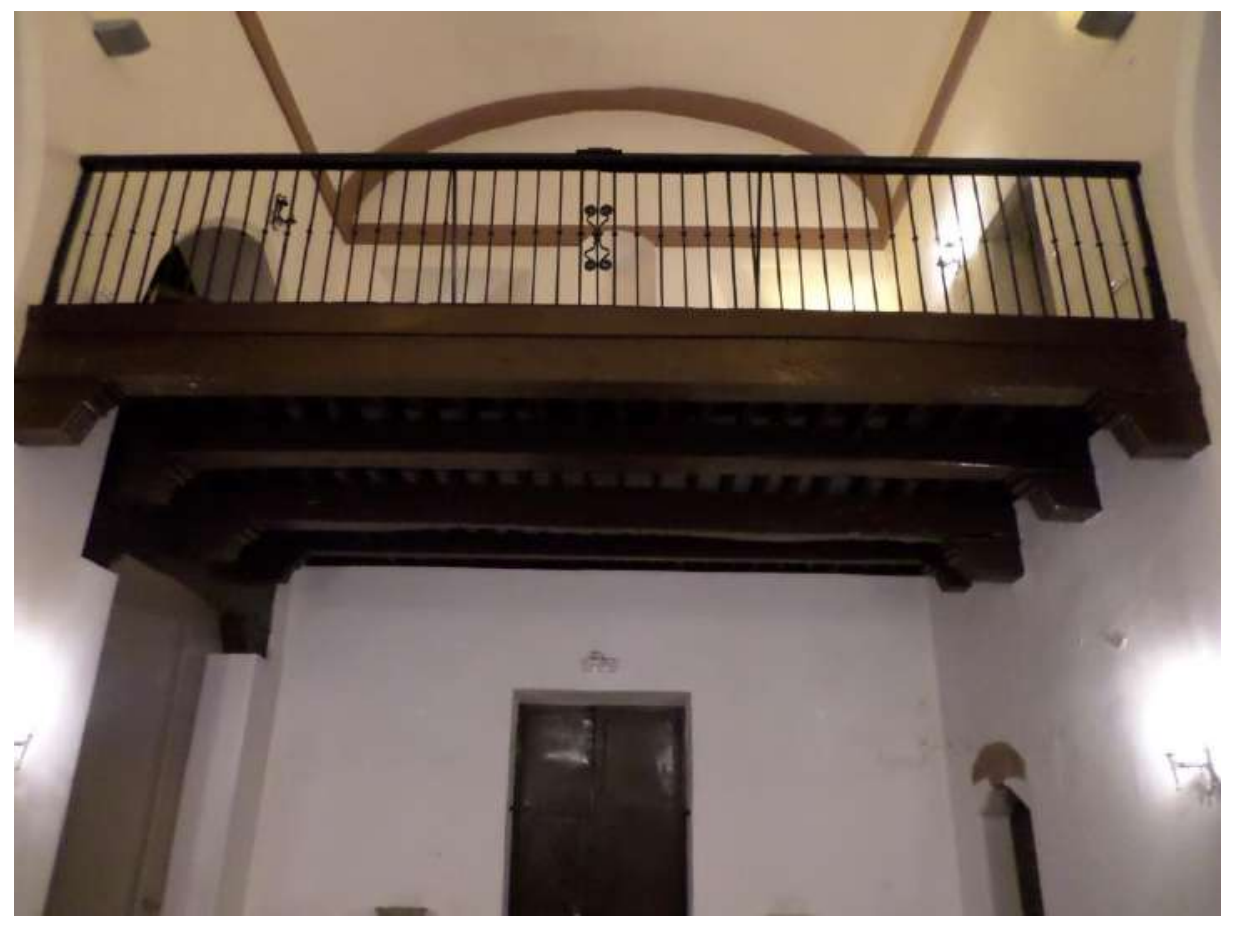

15) Alfarje del coro.

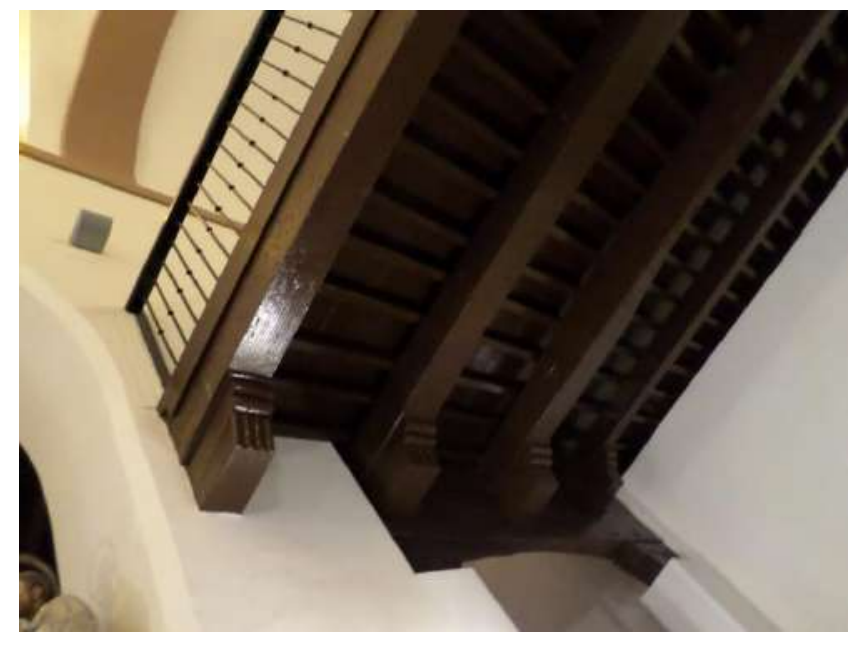

16) Detalle del alfarje. 


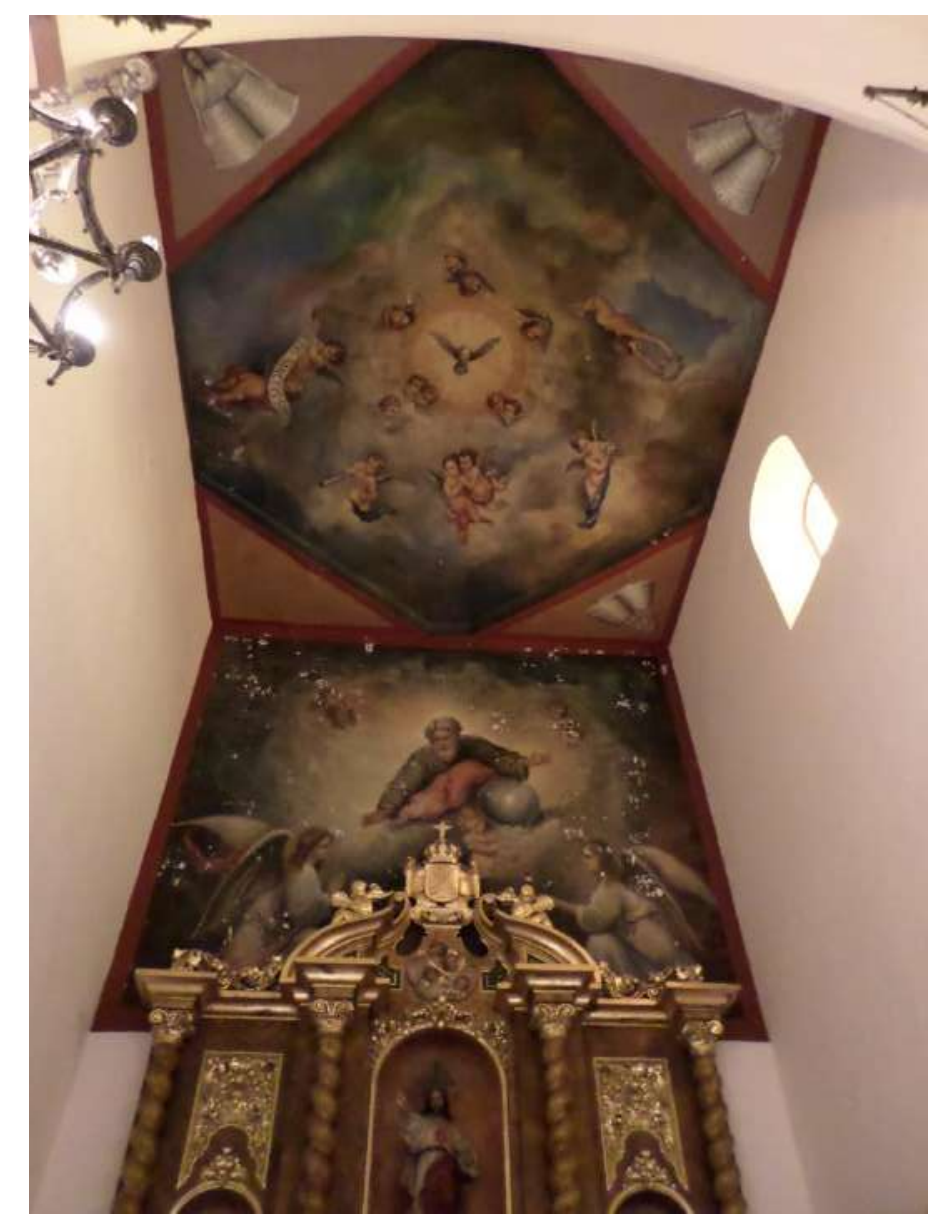

17) Bóveda plana ochavada de la capilla mayor.

Por último, hemos de describir la torre que se encuentra situada en el lado NO de la iglesia. La torre está construida en cintas de ladrillo y yeso y tiene una planta cuadrada. Los lados de la torre situados en el sur, este y oeste están formados solo del material de la que está formada, cintas de ladrillo y yeso hasta llegar al cuerpo de campanas que más adelante describiremos; en cambio, su lado norte contiene cuatro vanos en forma de arcos de medio punto. Esta torre tiene un cuerpo adicional separado por una cornisa donde hay un arco de medio punto en cada lado enmarcado con un alfiz en los que se sitúa las campanas. La torre está coronada por almenas de las que ya se hablaba en una visita pastoral del arzobispo de Granada, don Pedro de Castro, en $1591 .^{73}$

${ }^{73}$ GÓMEZ-MORENO CALERA, José Manuel. "Arte y Marginación. Las iglesias de Granada a finales del s.XVI", En: Actas de las III Jornadas La Religiosidad Popular y Almería. Almería: Instituto de Estudios Almerienses, 2004., págs. 291-312., pág. 304. 


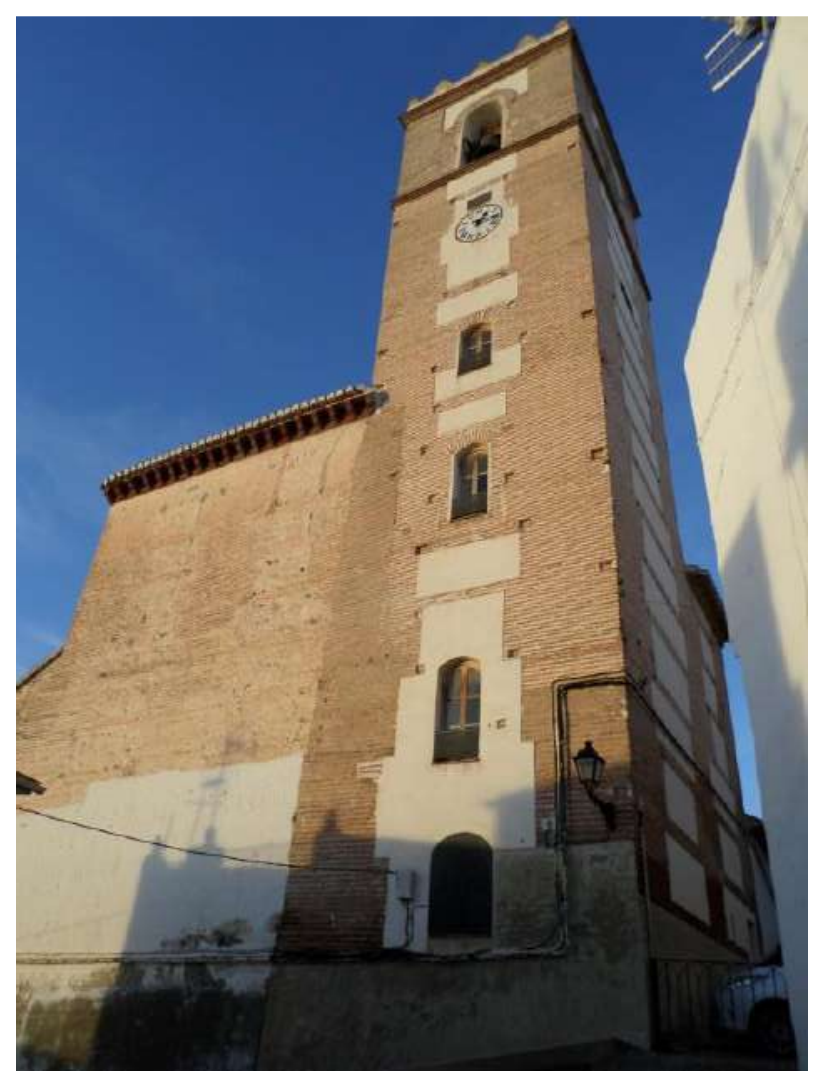

18) Torre.

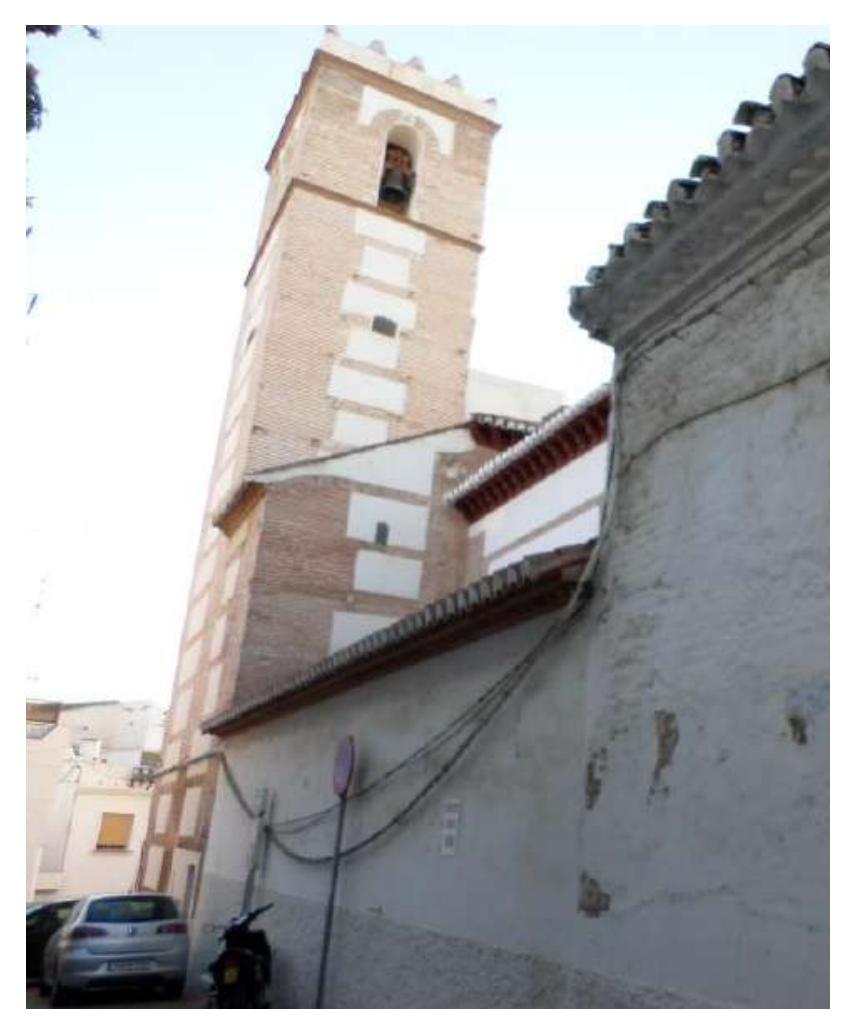

19) Vista de la torre. 
De la iglesia que hemos descrito, la parte mudéjar sería, en primer lugar, la predominante estructura espacial. Del gran espacio exterior, las cintas de ladrillo y yeso que aparecen en la parte de la nave central y capilla mayor, a la vez que la hermosa decoración de arcos y alfiz de la portada Este, y la torre de la iglesia. Del interior, hemos de mencionar como mudéjar, la armadura de la nave central, desaparecida en el incendio de 1821, y las armaduras de las naves laterales, junto con el oscuro alfarje que sostiene el coro.

\subsection{Iglesia de San Antonio de Lobres.}

La Iglesia de San Antonio de Lobres es una obra del s. XVI, ${ }^{74}$ cuyos materiales de construcción fueron la piedra, el ladrillo, el yeso y la madera.

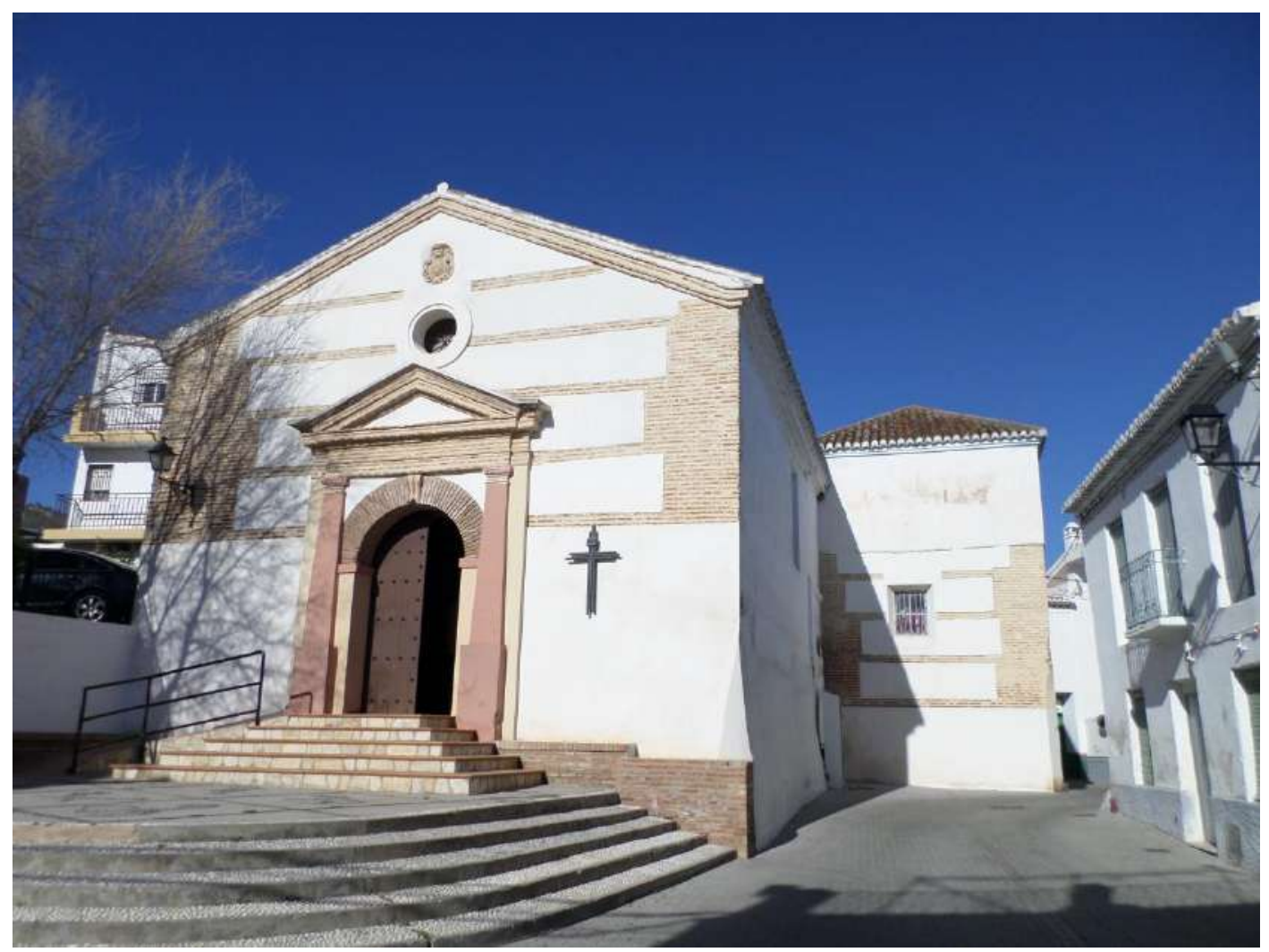

1) Iglesia de San Antonio de Lobres.

La iglesia tiene una única nave rectangular con cuatro arcos diafragmas apuntados, uno de ellos es el arco toral de acceso a la capilla mayor y el otro está incorporado en el coro y con capillas laterales entre contrafuertes a las que se accede por medio de arcos de medio punto con clave e impostas decoradas, y capilla mayor

\footnotetext{
${ }^{74}$ VV.AA. Guía artística de Granada y su.... Op. cit., pág. 188.
} 
diferenciada. ${ }^{75}$ La nave presenta coro a los pies sostenido por un arco carpanel decorado con yesería y sostenido a la vez por pilares dóricos, es ancha y alta y por ella se accede a la capilla mayor rectangular por medio de un arco toral apuntado. Esta capilla mayor fuer realizada en $1645 .^{76}$ Accedemos a la capilla de la Virgen de la Candelaria por el lateral derecho de la nave de la iglesia realizada en el s. XVII.

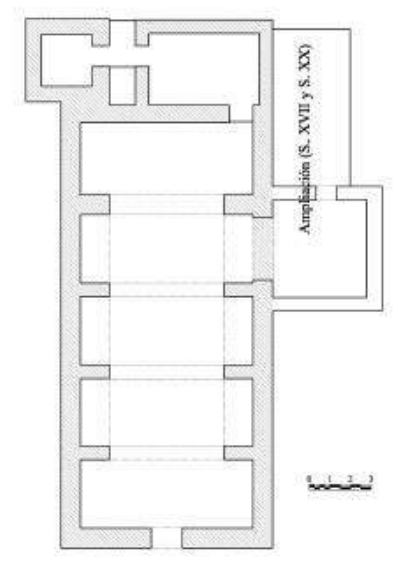

2) Plano de la Iglesia. ${ }^{77}$

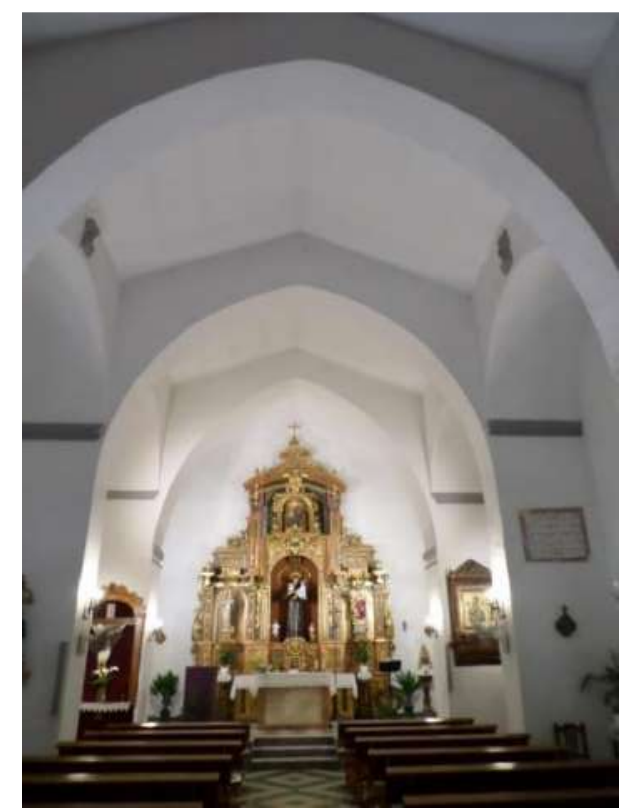

3) Nave de la iglesia.

${ }^{75}$ Este tipo de planta de nave única rectangular con arcos diafragma, capillas laterales entre contrafuertes y capilla mayor separada por un arco toral, responde a las tipologías de planta de iglesias mudéjares de Granada según el estudio realizado por Don Rafael López Guzmán y Don Ignacio Henares Cuéllar en:

HENARES CUÉLLAR, Ignacio; LÓPEZ GUZMAN, Rafael. Arquitectura Mudéjar.... Op. cit.

${ }^{76}$ VV.AA. Guía artística de Granada y su.... Op. cit., pág. 188.

${ }^{77}$ MARTÍN GARCÍA, Mariano. "Iglesias Fortificadas.... Op. cit., pág. 733. 


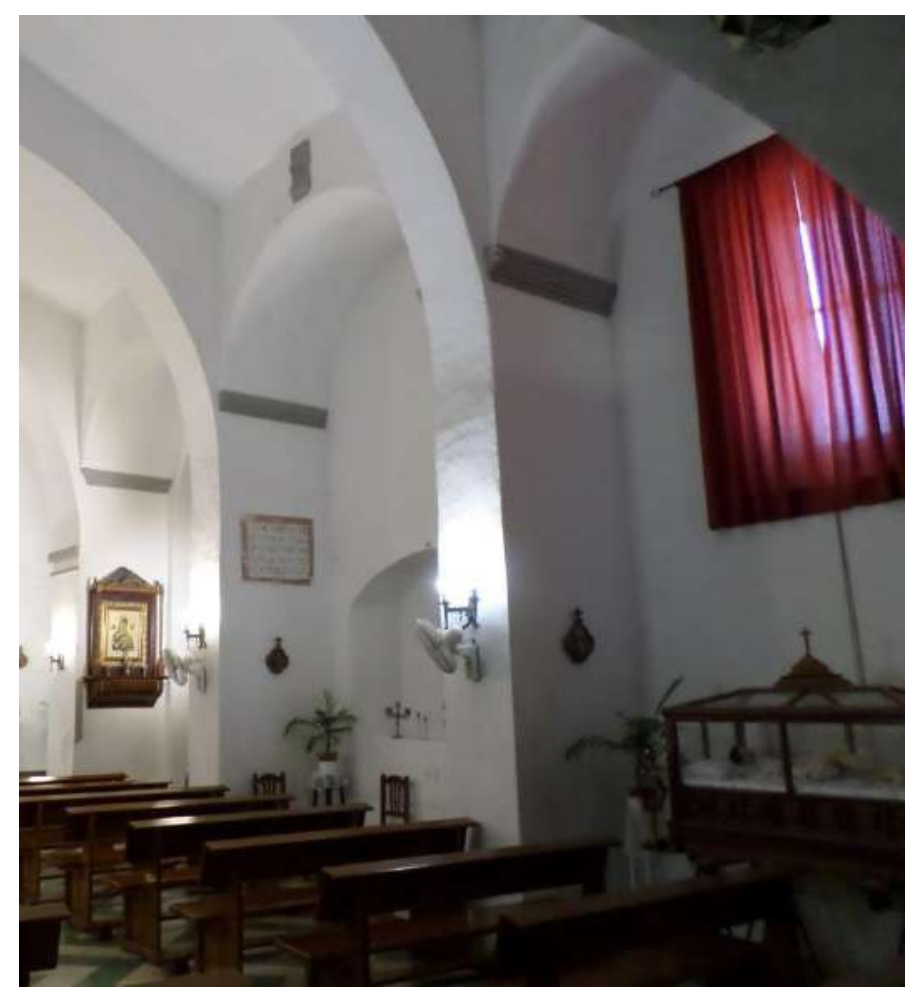

4) Capillas entre contrafuertes.

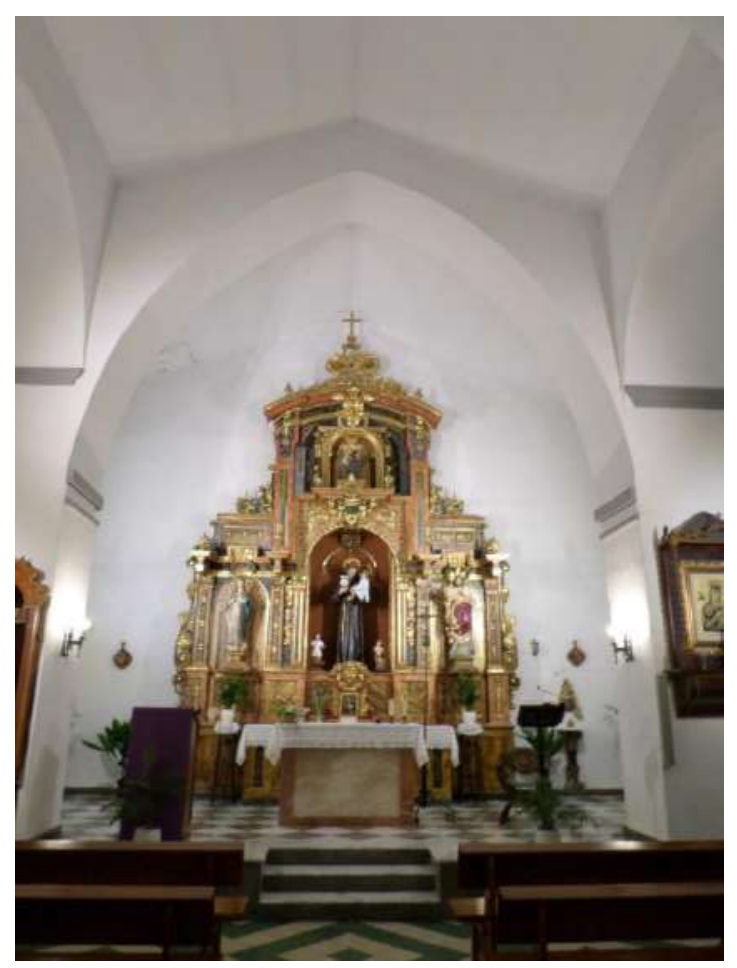

5) Arco toral y capilla mayor. 


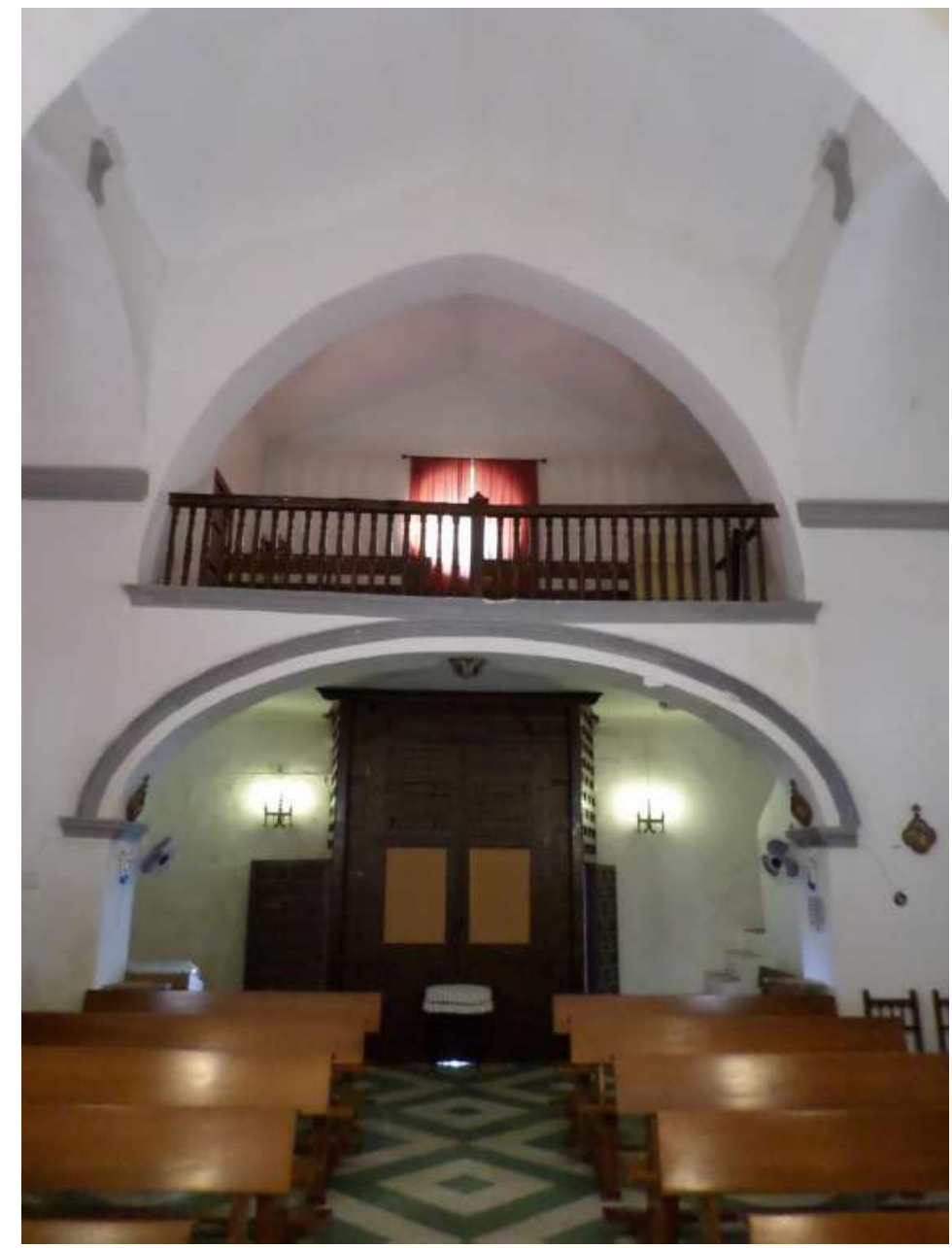

6) Coro.

En el exterior, en primer lugar, hemos de indicar que la iglesia destaca por sus contrastes ya que en unos lugares está revocada y en otros está revocada parcialmente, percibiéndose las cintas de ladrillo y yeso de la que está realizada. Aunque por testimonio vecinales sabemos que antes de la Guerra Civil todo el exterior estaba sin revocar. Hoy esté revocado el muro lateral izquierdo y el muro lateral derecho, parcialmente la fachada principal y la zona de la capilla de la Virgen de la Candelaria en su exterior. En la fachada principal se sitúa la puerta de acceso al templo enmarcada por un arco de medio punto con clave realizado en ladrillo y sostenido por pilastras dóricas también de ladrillo, rodeado a su vez por dos grandes pilares que sostienen un arquitrabe y un frontón triangular. Coronando esta portada aparece un óculo y encima el escudo heráldico del arzobispo Don Pedro de Castro. Esta fachada principal es de entre 
1590 y $1610 .{ }^{78}$ La pared exterior norte de la iglesia tiene también cintas de ladrillo y yeso y dos vanos adintelados.

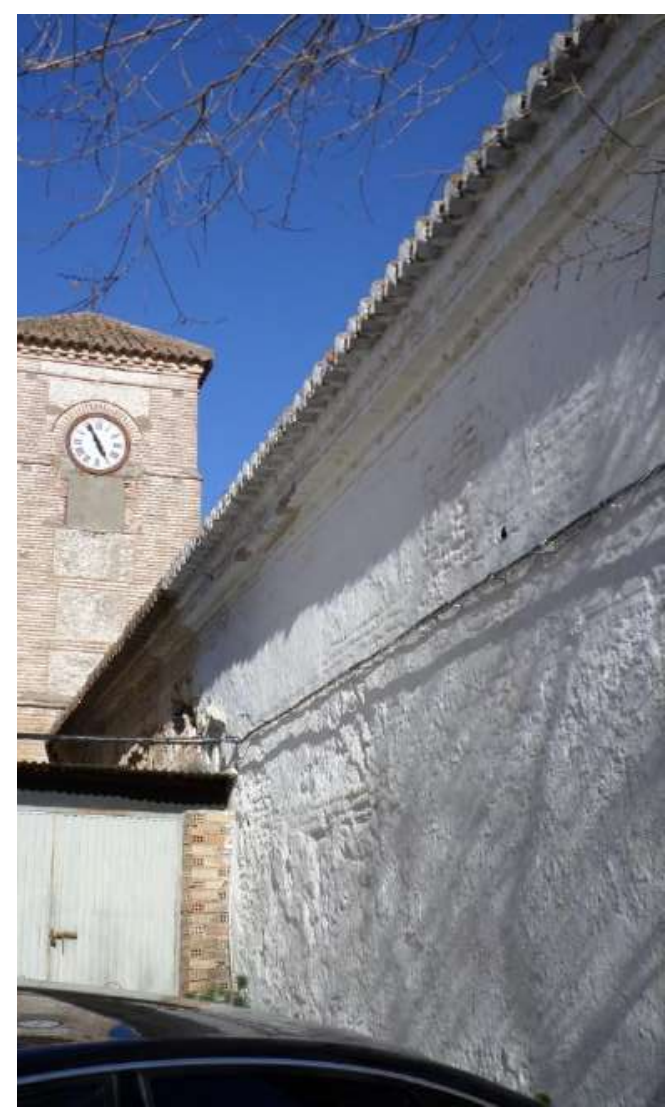

7) Lateral izquierdo de la iglesia.

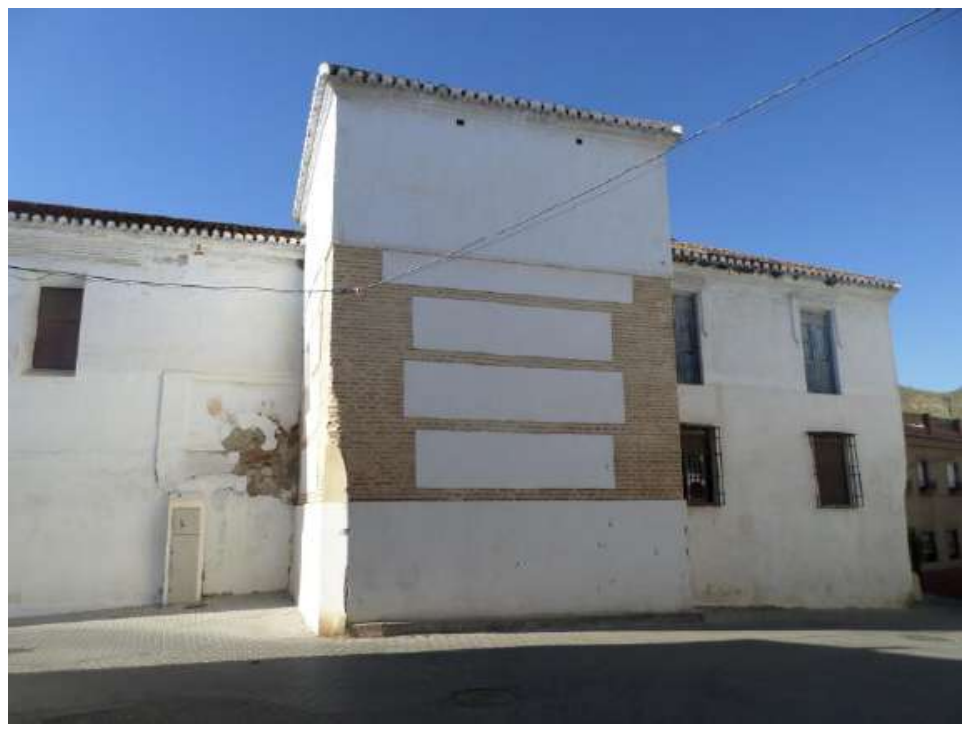

8) Lateral derecho de la iglesia.

${ }^{78}$ VV.AA. Guía artística de Granada y su.... Op. cit., pág. 188. 


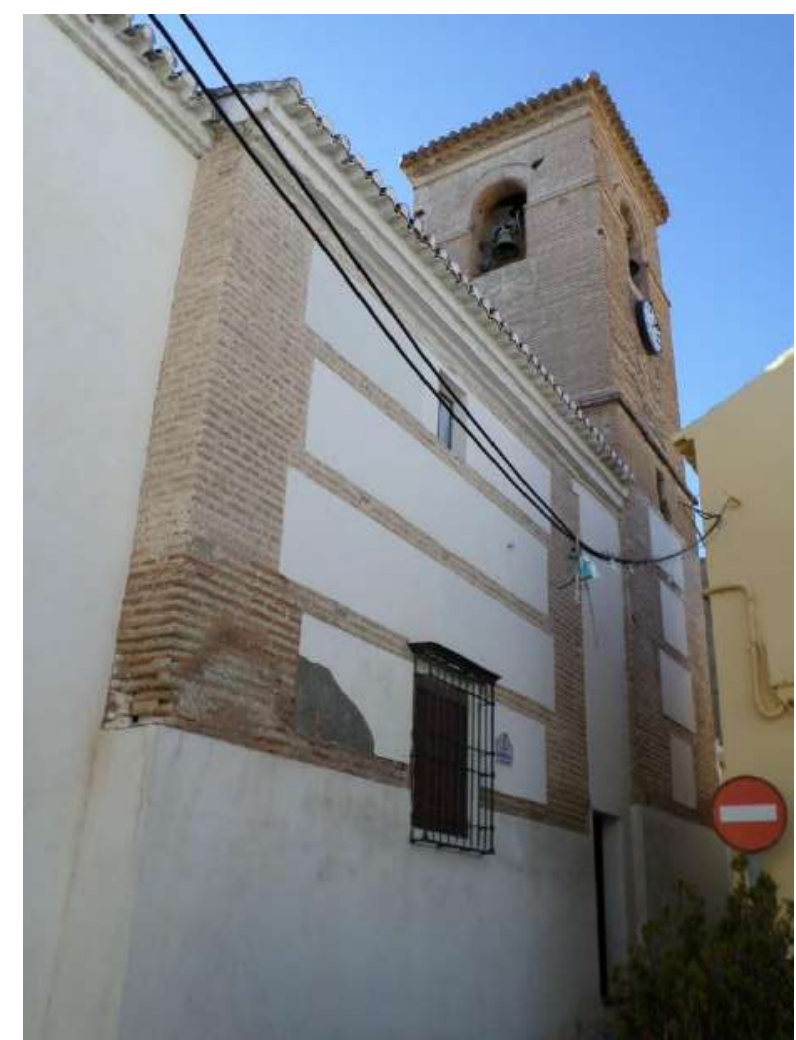

9) Fachada norte de la iglesia.

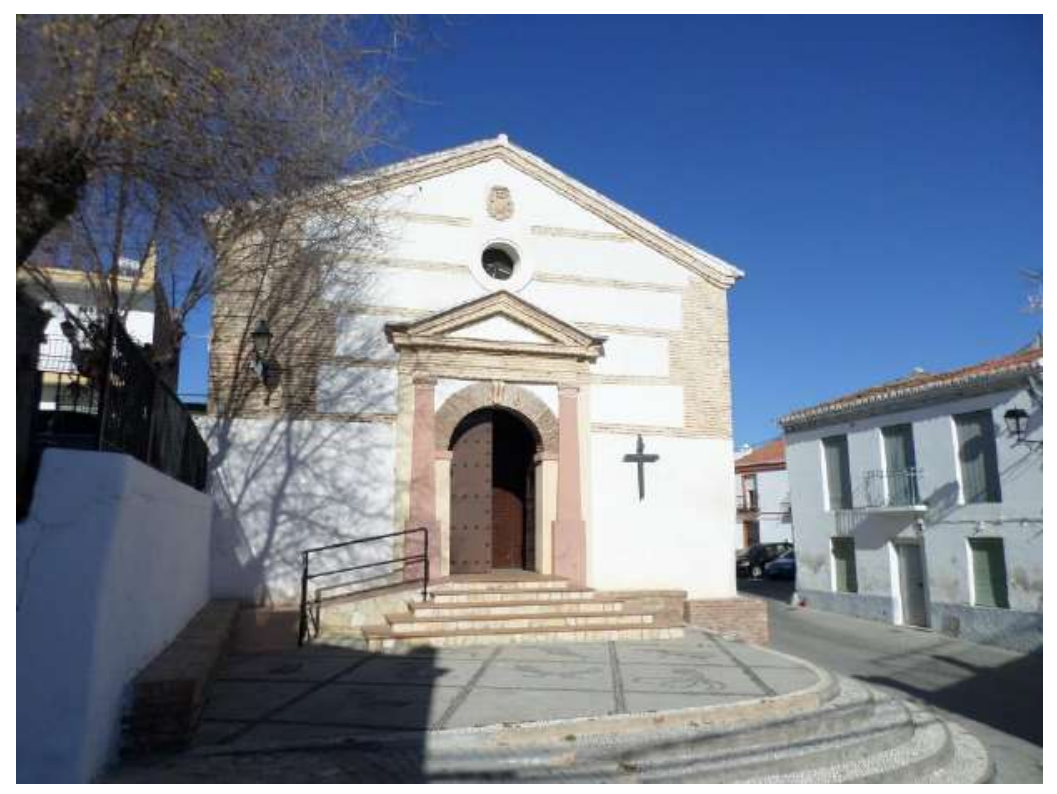

10) Fachada principal. 
En el interior, hay que indicar que los muros de la iglesia son gruesos, cumplen la función de cerramiento y sustento del peso de los predominantes y grandes elementos superiores y dan gran sensación de solidez. Los arcos diafragma que hemos descrito más arriba sostenían la armadura de colgadizo que fue desmantelada en $1980^{79}$ y fue sustituida por una estructura de hormigón. Esta armadura llegaba a la capilla mayor y al coro.

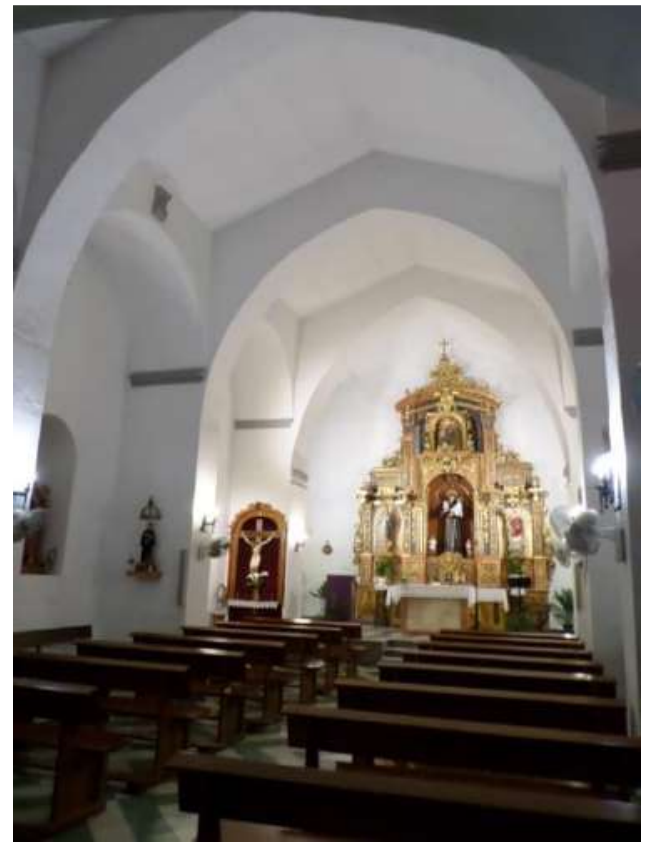

11) Nave con arcos diafragma.

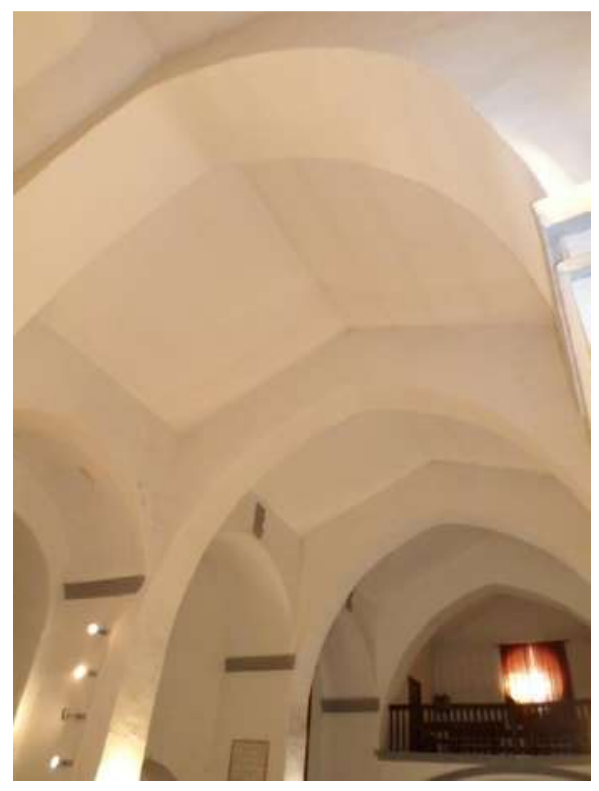

12) Techo de hormigón que sustituye a la armadura.

79 Testimonios de los vecinos así nos lo confirman. La armadura, debido al mal estado, fue desmantelada y sustituida por el techo actual de hormigón. No tenemos detalles de dicha armadura. 
Por último, hemos de describir la torre que está realizada en cintas de ladrillo y yeso y cajones de mampostería y está situada en el lado NO de la iglesia y no está revocada por lo que nos permite ver todo su esplendor mudéjar primitivo. Esta torre tiene tres grandes cuerpos separados por cornisas de ladrillo, y entre el segundo cuerpo y el tercer cuerpo se sitúa un arco de medio punto con un predominante alfiz donde se colocan las campanas, en tres de sus cuatro lados.

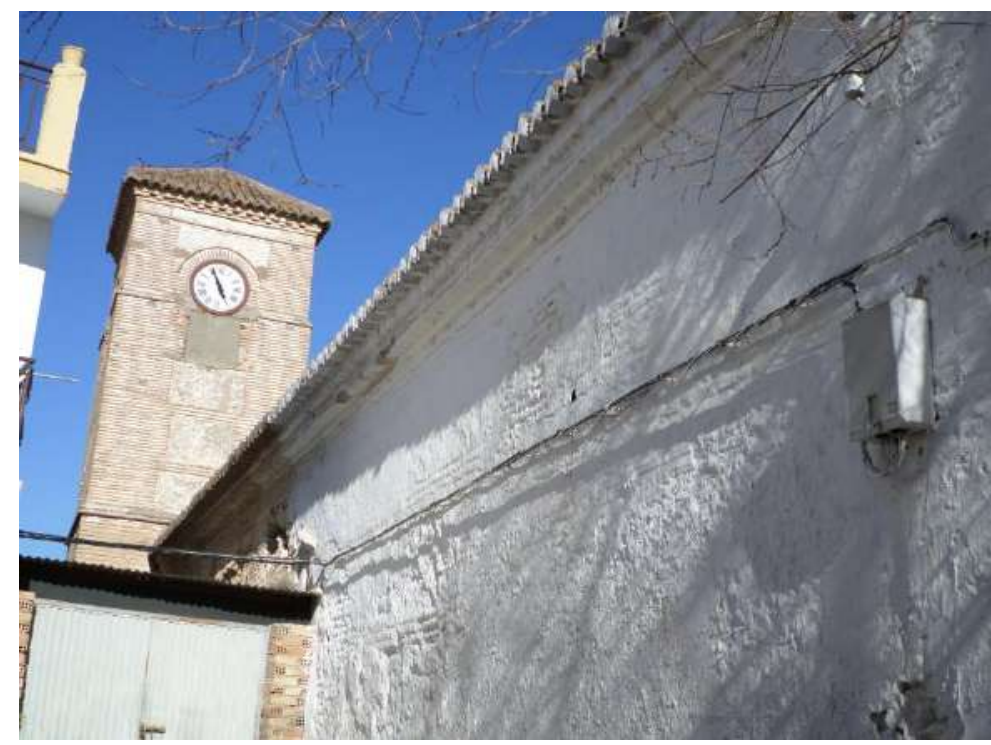

13) Vista de la torre.

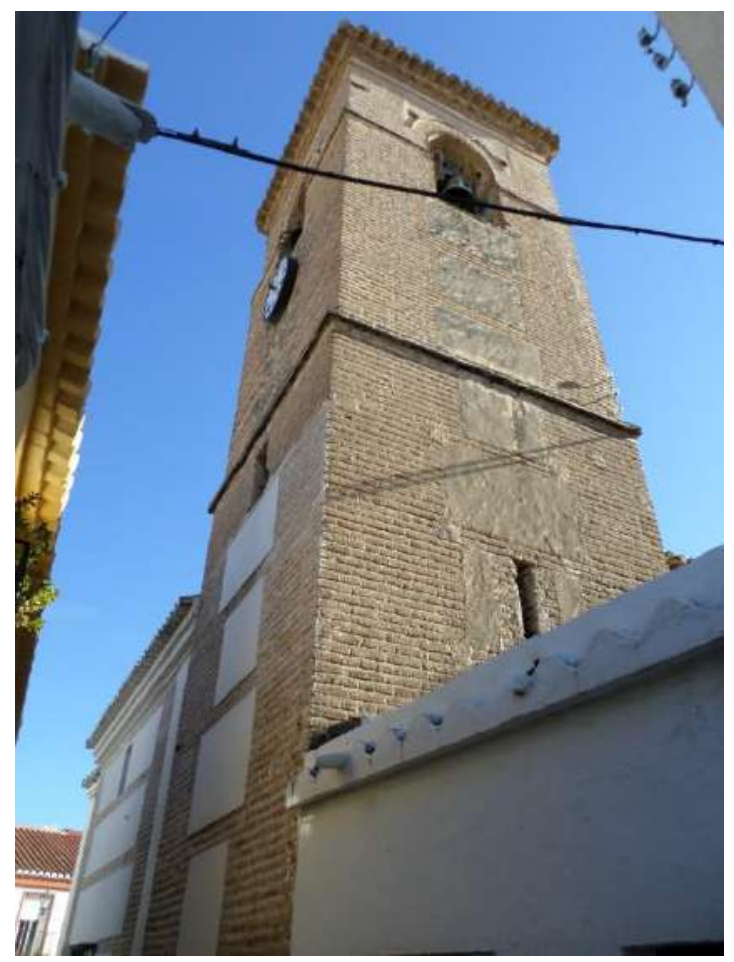

14) Torre. 
De la iglesia que hemos descrito, la parte mudéjar sería, en primer lugar, la estructura espacial. Del exterior, las cintas de yeso y ladrillo y cajones de mampostería, aunque por desgracia estén parcialmente revocado, aunque en la torre podemos percibirlo como hemos podido comprobar. La gran portada de ladrillo de la fachada principal. Del interior de única nave con sus grandes arcos diafragmas apuntados y la antigua armadura de colgadizo desaparecida.

\subsection{Iglesia de San Antonio de Padua de Guájar Fondón.}

La Iglesia de San Antonio de Padua de Guájar Fondón fue reconstruida en 1607, pero su construcción es anterior a esa fecha, reformada en 1798, siendo proyectada toda la estructura de madera por el carpintero Agustín Durazgo. ${ }^{80}$ Este templo fue construido en piedra, ladrillo, yeso y madera, aunque algunos de estos materiales aparezcan revocados en el exterior como veremos más adelante.

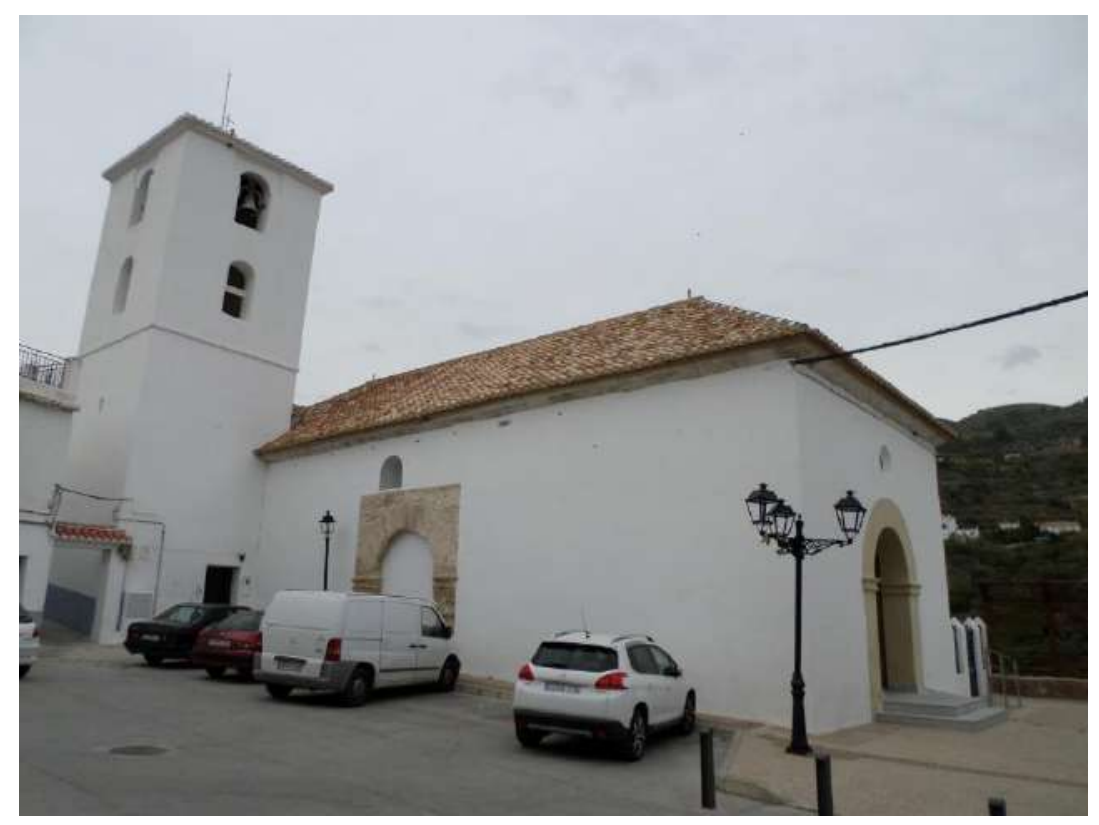

1) Iglesia de San Antonio de Padua de Guájar Fondón.

La iglesia tiene una nave única rectangular sin capilla mayor ${ }^{81}$ a través de la que se accede a la sacristía. La nave presenta coro a los pies.

${ }^{80}$ VV.AA. Guía artística de Granada y su.... Op. cit., pág. 178.

${ }^{81}$ Este tipo de planta de nave única rectangular y sin capilla mayor diferenciada, cubierta por una armadura, como se describe más adelante, responde...Op. cit. 


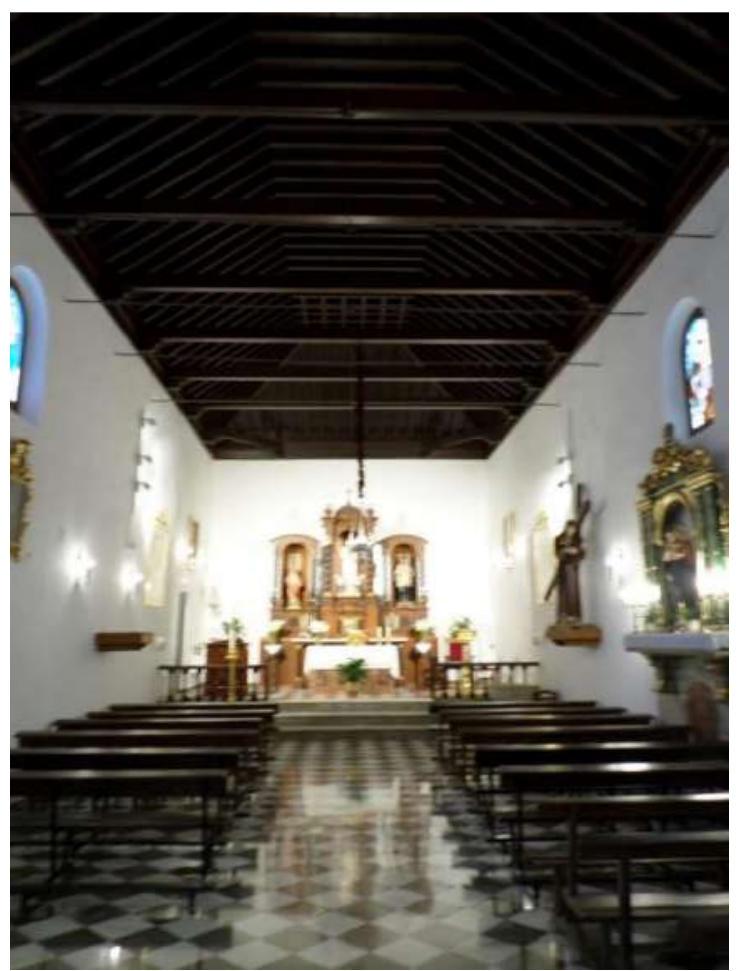

2) Nave de la iglesia.

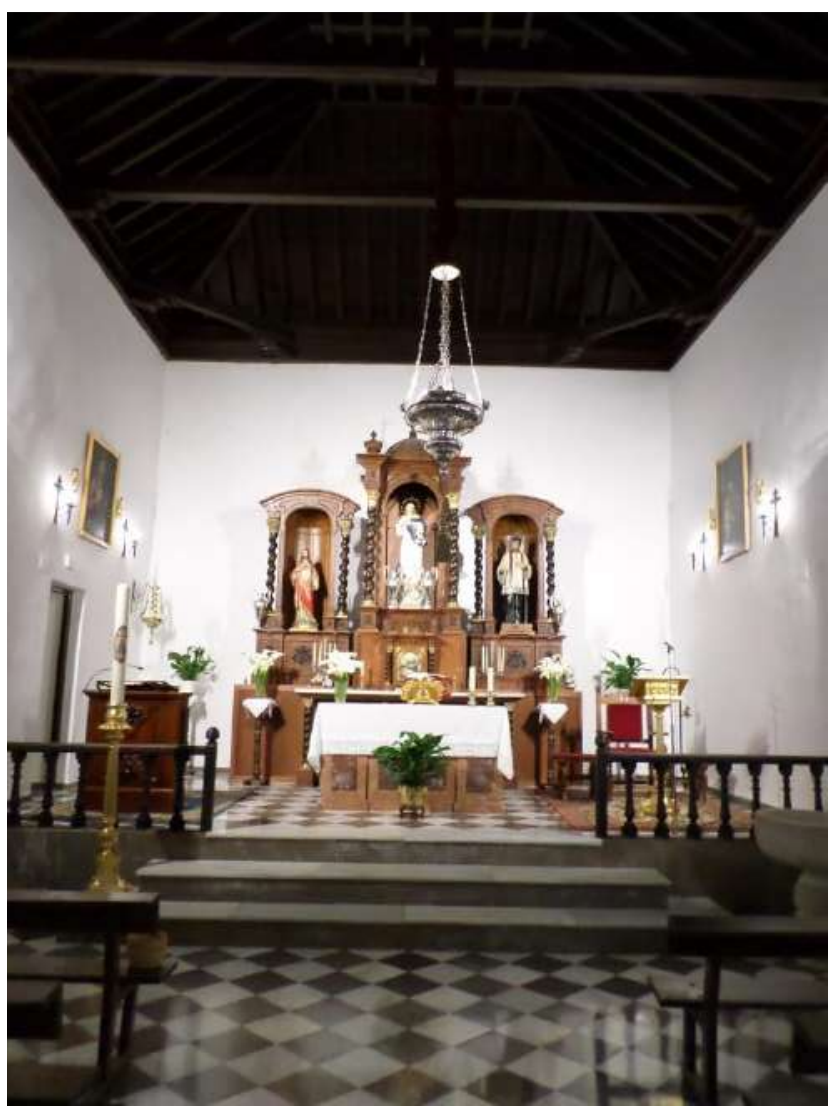

3) Capilla mayor. 


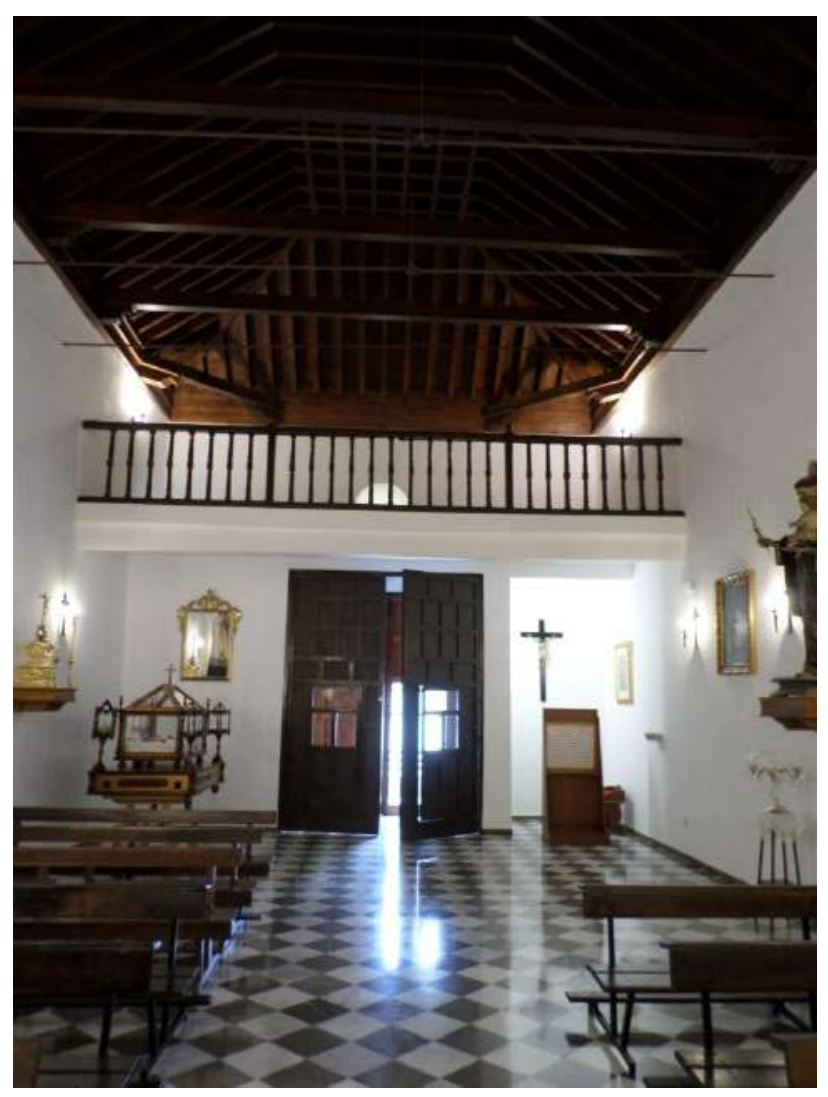

4) Coro.

En el exterior, hemos de indicar, que actualmente está revocada, pero hace alrededor de 60 años no estaba así y se percibían las cintas de ladrillo y yeso muy propio del estilo mudéjar de la iglesia. ${ }^{82}$ En este exterior hemos de destacar la fachada principal y el lateral izquierdo. La fachada principal consta de la puerta de acceso principal al templo que está enmarcada por un arco de medio punto sostenido por pilastras con capitel dórico, realizado en ladrillo y que en los mismos años que el resto del exterior estaría sin revocar. ${ }^{83}$ Un óculo aparece encima de este arco. El lateral izquierdo destaca por tener otro acceso al templo, pero hoy cerrado. ${ }^{84}$ Este acceso presenta una portada de piedra formada por un arco de medio punto de sillares sostenido por pilares dóricos y rodeado por un alfiz, y encima de esta portada un vano en forma de arco de medio punto que ilumina el interior del templo.

\footnotetext{
${ }^{82}$ Según nos relatan los vecinos del pueblo.

${ }^{83}$ Ibídem.

${ }^{84}$ Ibíd.
} 


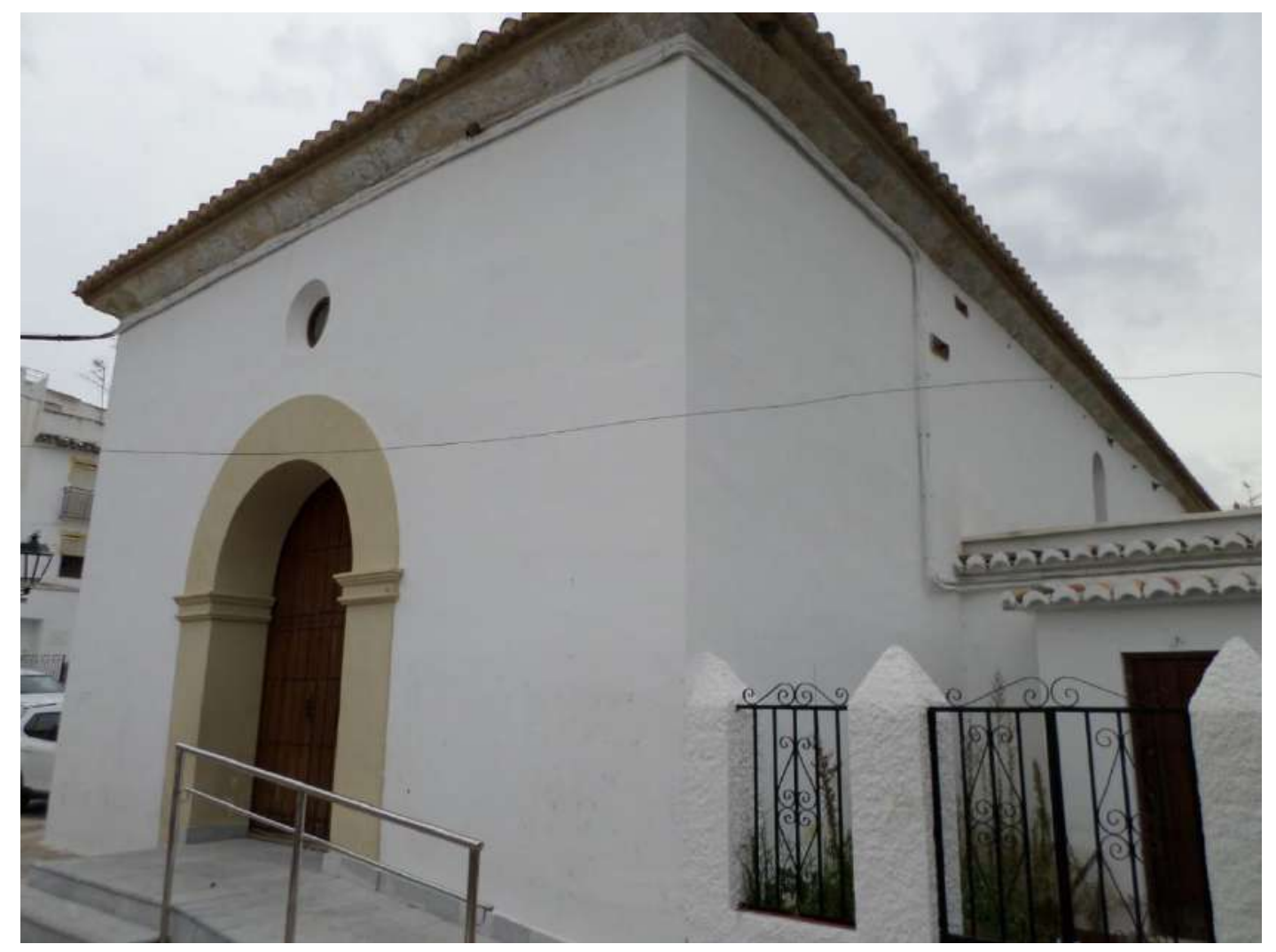

5) Fachada principal.

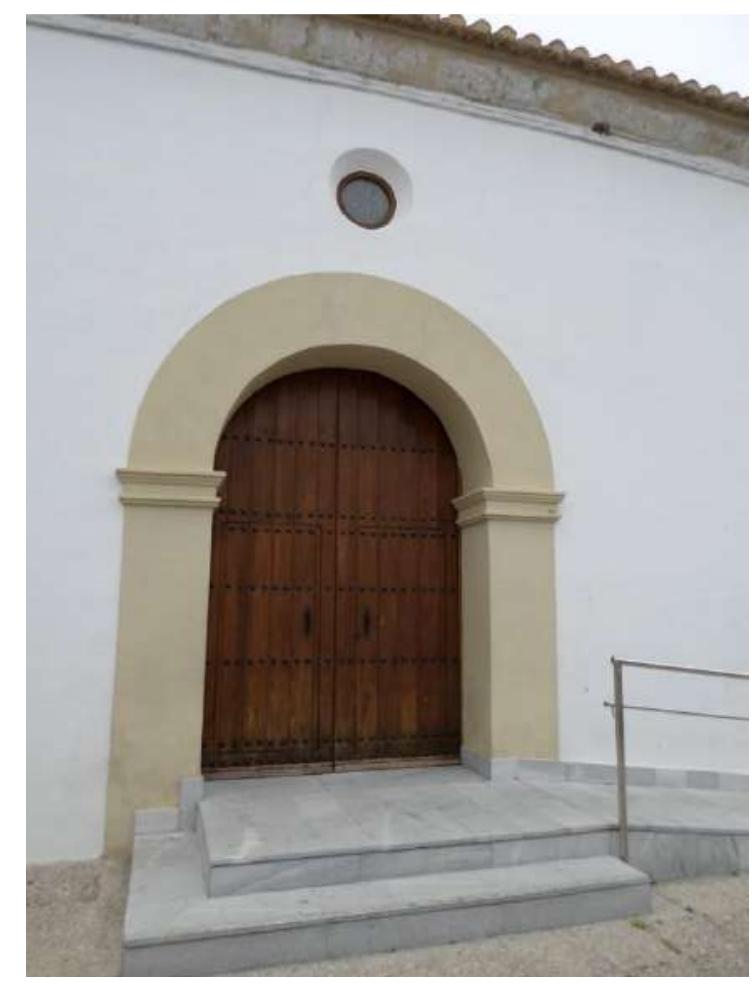

6) Portada de la fachada principal. 


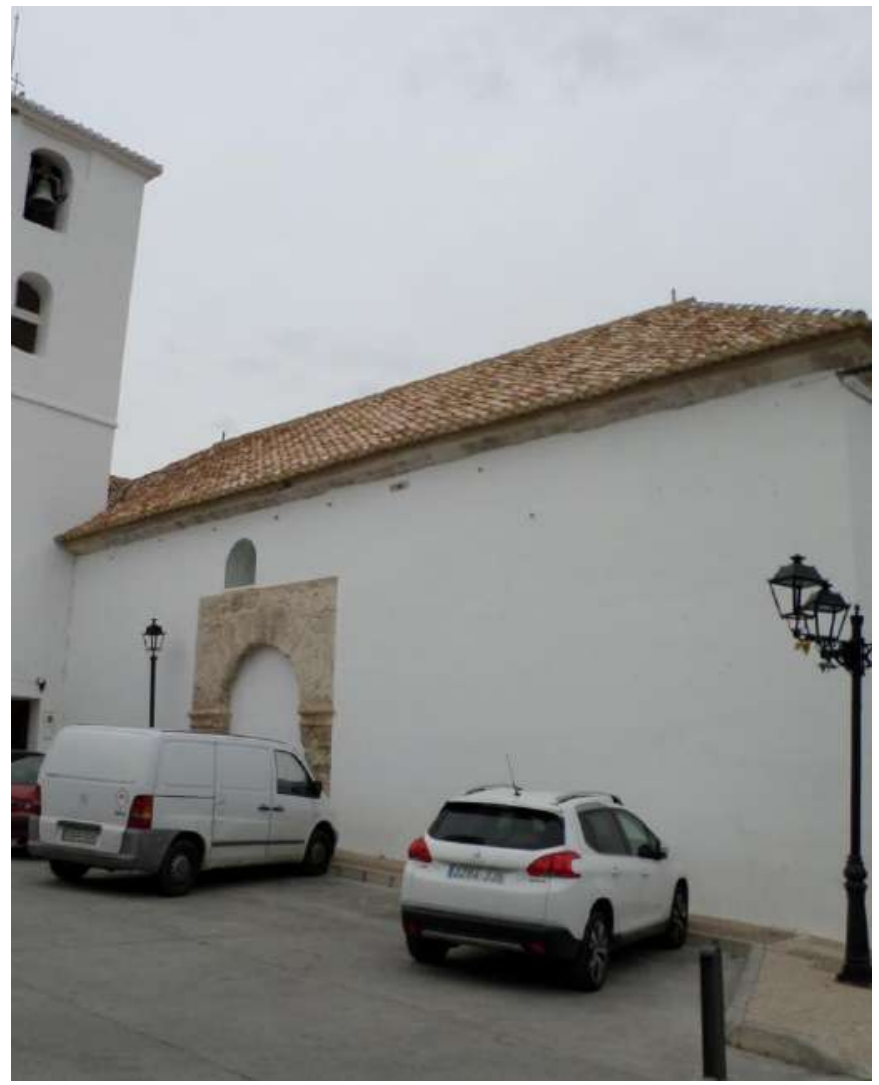

7) Lateral izquierdo de la iglesia.

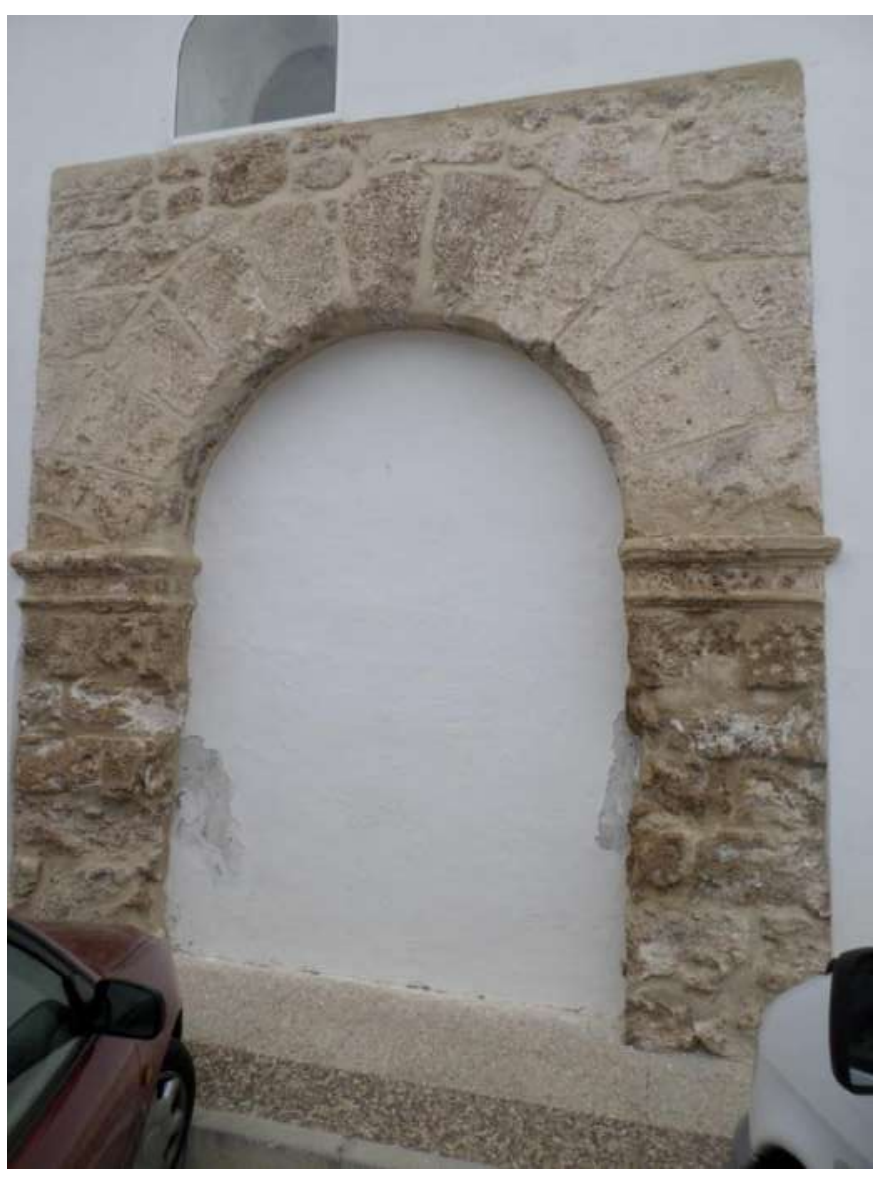

8) Portada del lateral izquierdo. 
En el interior, hay que destacar que los muros cumplen la función de cerramiento del espacio y de descarga de los elementos superiores, y dan gran sensación de solidez. La nave de la iglesia está cubierta por una armadura de lima bordón con tirantes simples sostenido por canes manieristas y por cuadrales con canes también manieristas. Los pares de la armadura no presentan decoración, aunque si lo presenta los extremos del almizate, que en este caso es una decoración reticular. Hay que indicar que esta armadura es de $1717^{85}$, aunque fue restaurada en el año 2017, conservándose sólo los canes de la armadura original. ${ }^{86} \mathrm{El}$ coro actualmente está sostenido por una estructura de hormigón, pero en su origen tenía un alfarje del que no tenemos ningún detalle y el cual estaría dividido por el sotocoro. ${ }^{87}$

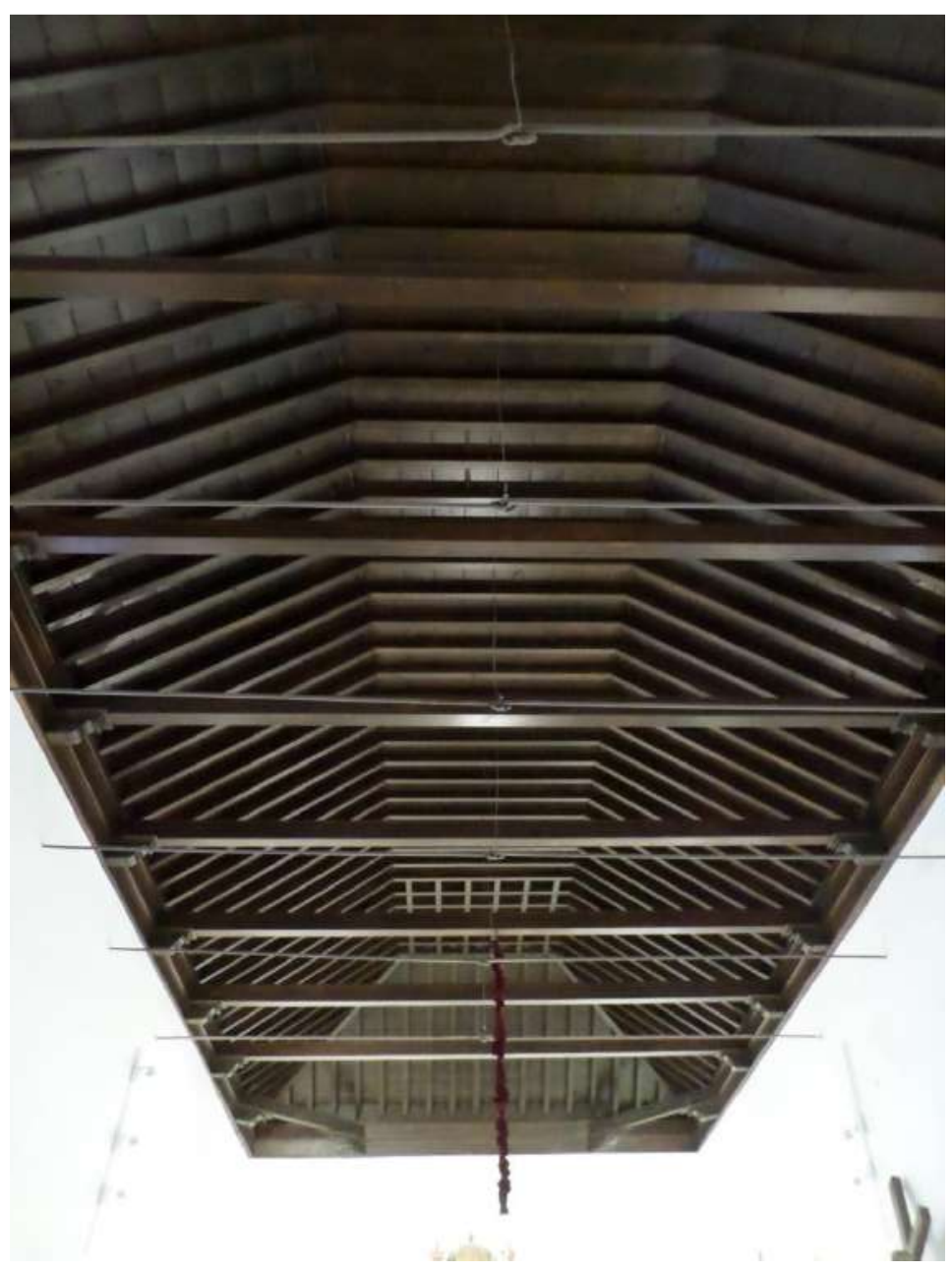

9) Armadura de la nave.

\footnotetext{
${ }^{85}$ VV.AA. Guía artística de Granada y su.... Op. cit., pág. 178.

${ }^{86}$ Según nos relatan los vecinos del pueblo.

${ }^{87}$ Ibídem.
} 


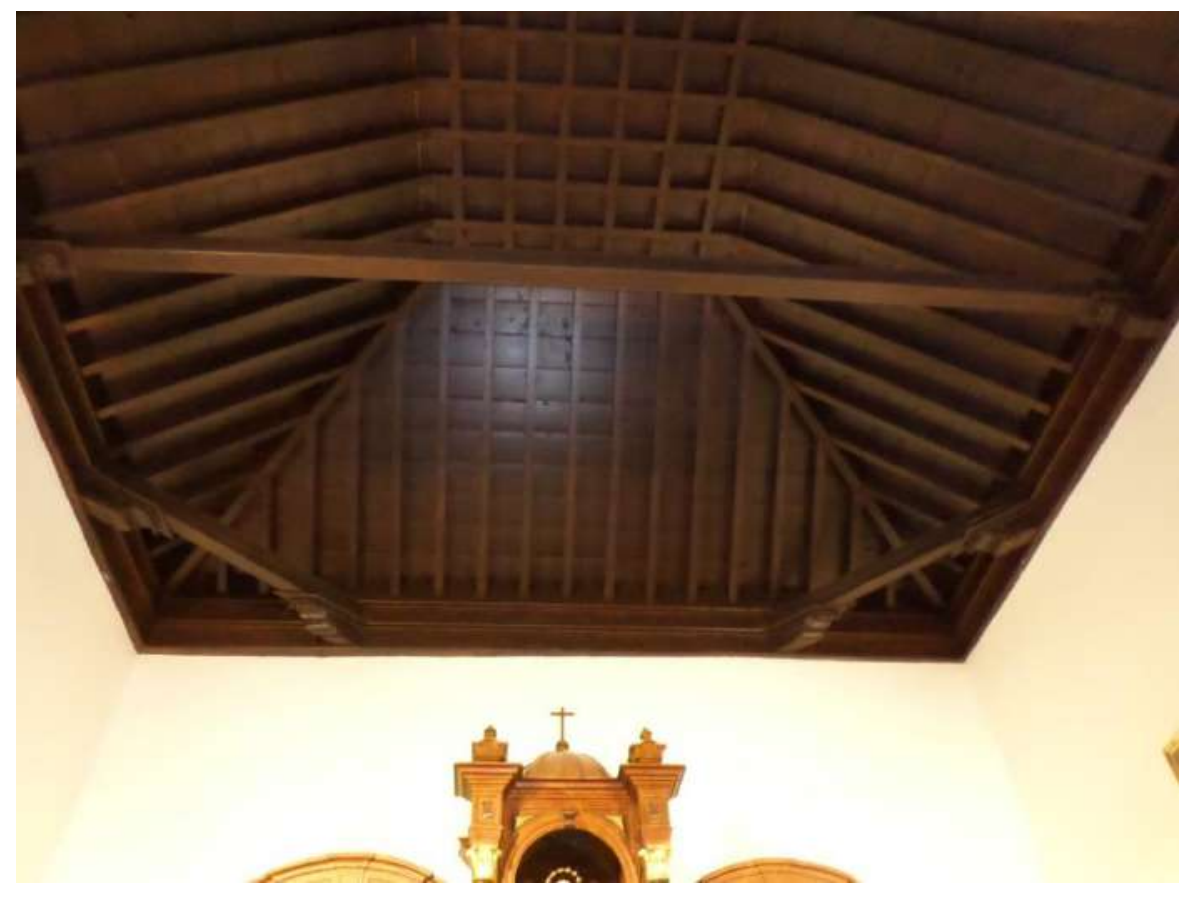

10) Detalle de la armadura.

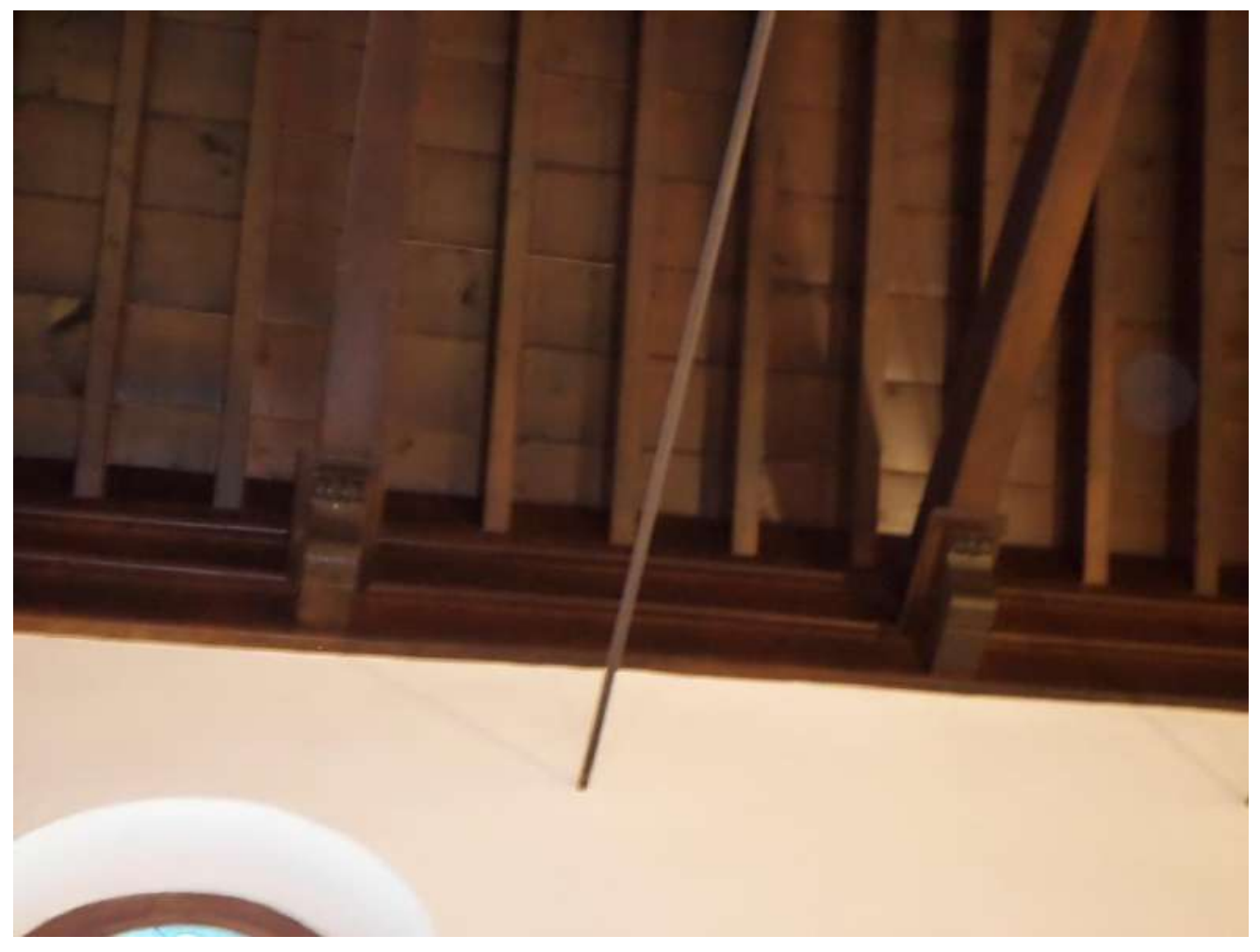

11) Canes de los tirantes de la armadura. 


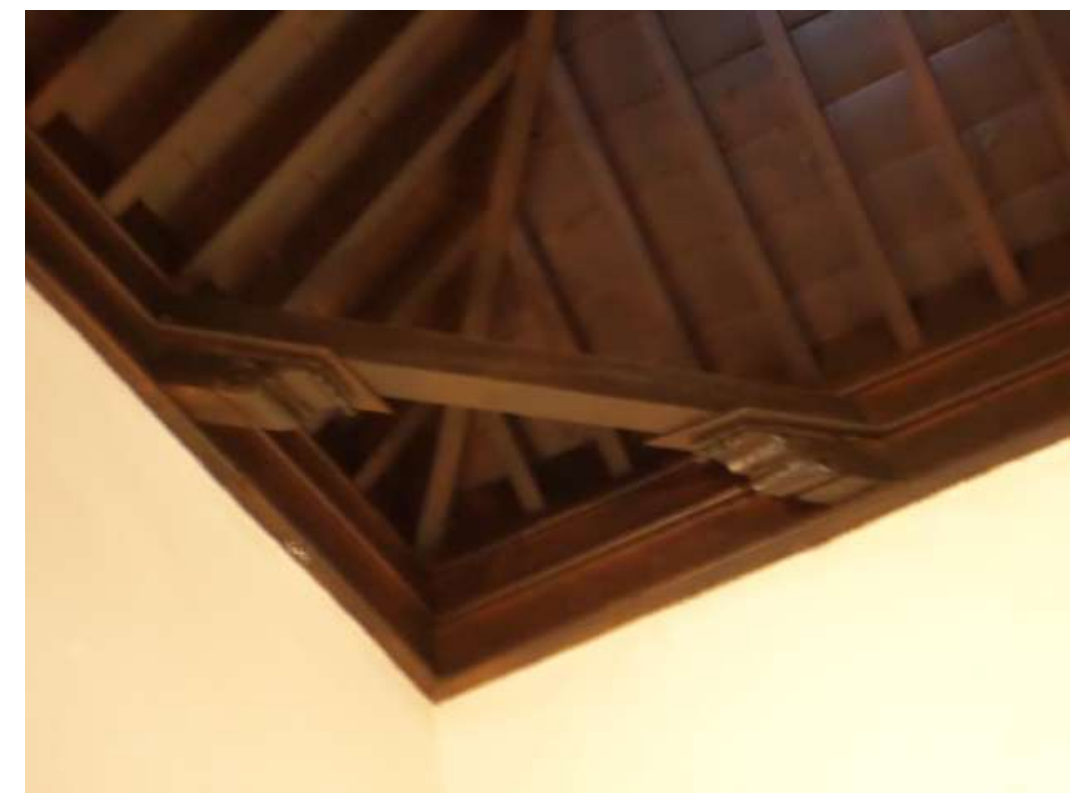

12) Cuadrales de la armadura.

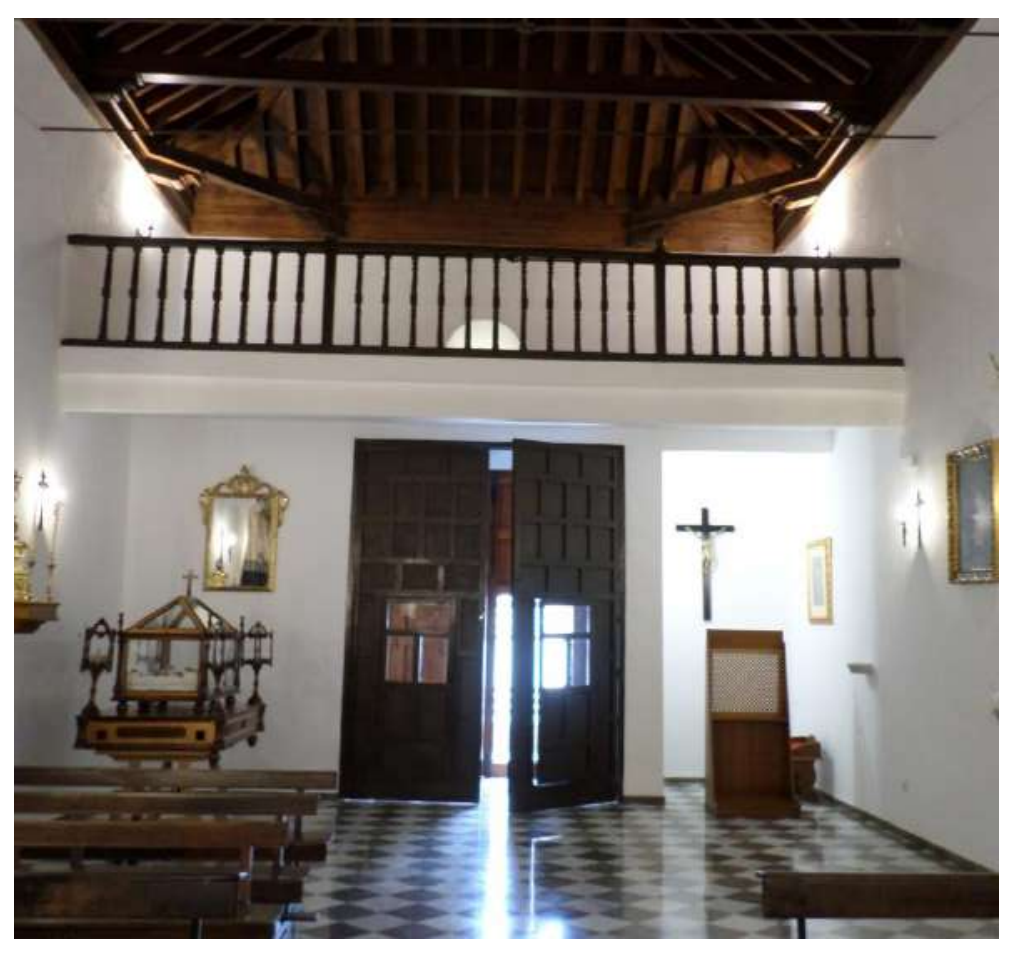

13) Alfarje.

La torre de la iglesia se sitúa en el lado NE y está construida en cintas de ladrillo y yeso, aunque revocada actualmente. ${ }^{88}$ La torre presenta dos cuerpos separados por una

${ }^{88}$ Ibíd. 
cornisa. El segundo cuerpo contiene dos vanos con forma de arcos de medio punto situados unos encima del otro en cada uno de los cuatro lados de la torre, en el vano superior se sitúan las campanas.

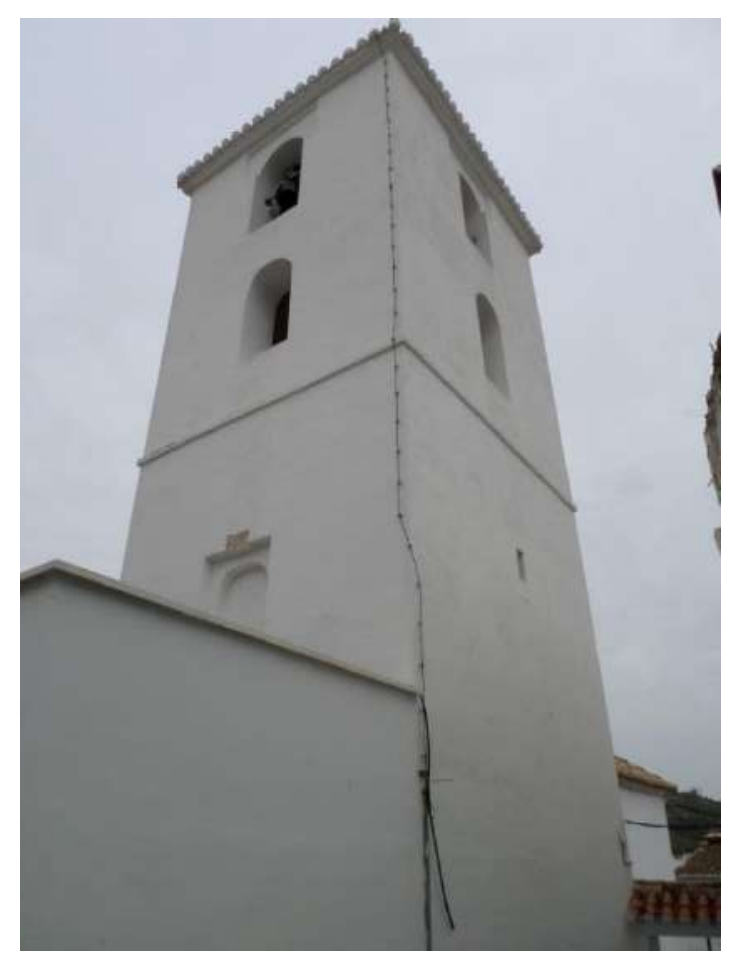

14) Torre.

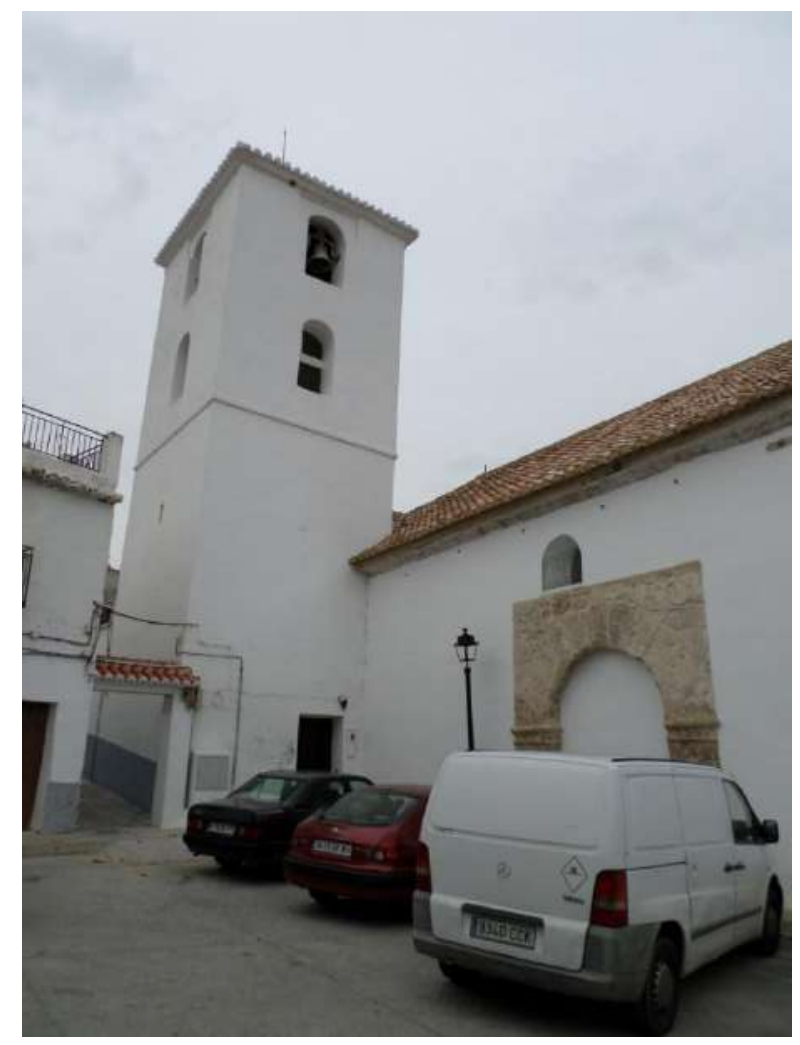

15) Vista de la torre. 
De la iglesia que acabamos de describir, la parte mudéjar sería, en primer lugar, la diáfana estructura espacial. Del espacio exterior, las cintas de ladrillo y yeso, junto con la portada principal, la portada lateral izquierda y la torre; y del interior., la armadura y el alfarje desaparecido.

\subsection{Iglesia Matriz de San Lorenzo de Guájar Faragüit.}

La Iglesia Matriz de San Lorenzo de Guájar Faragüit se construyó en la segunda década del s. XVI, aunque se reformó decorativamente en $1763 .{ }^{89} \mathrm{El}$ templo fue construido en piedra, ladrillo, yeso y madera.

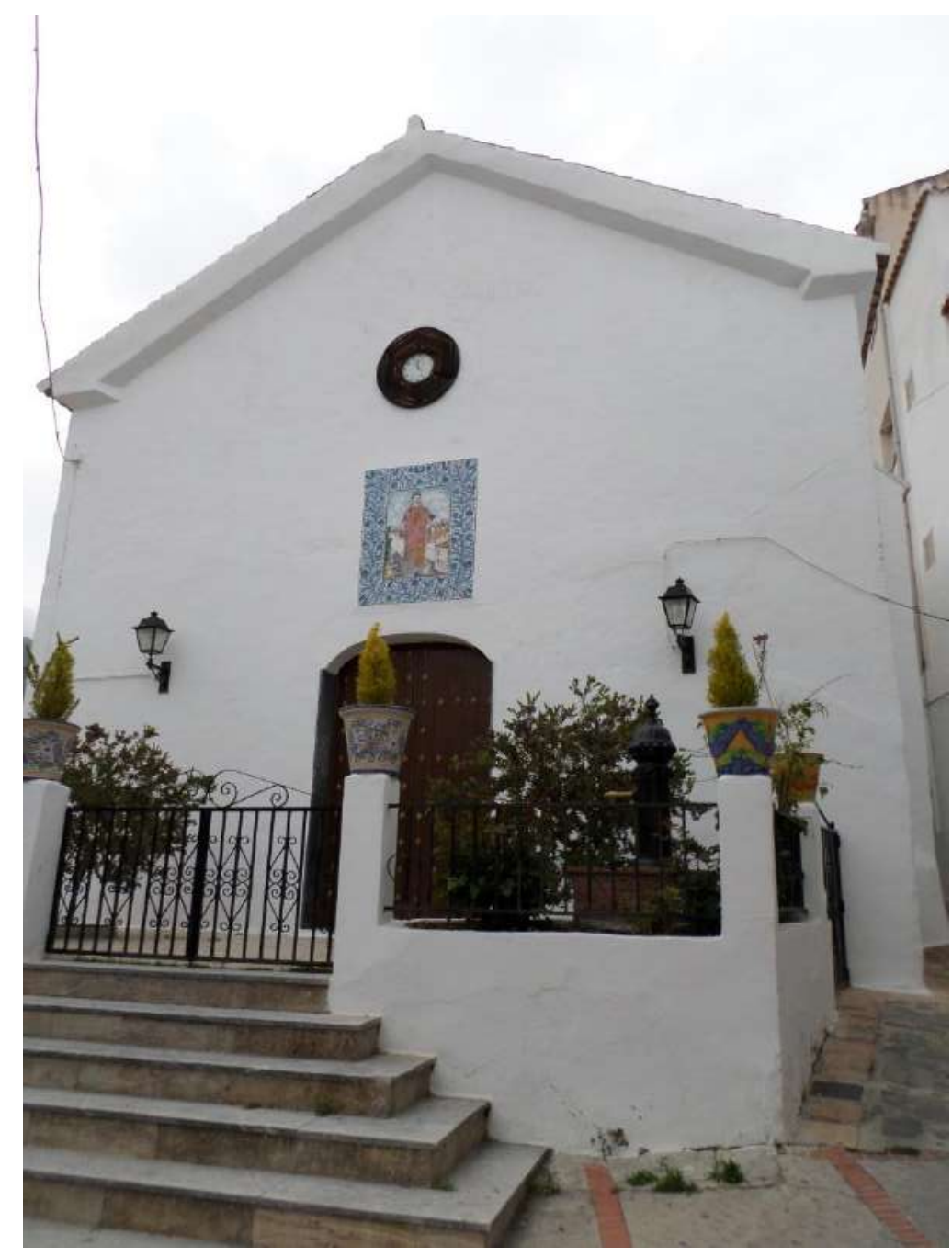

1) Iglesia Matriz de San Lorenzo de Guájar Faragüit.

La iglesia tiene una nave única rectangular que contiene tres arcos diafragma apuntados y sostenidos por columnas dóricas de mármol sobre las que está colocada la

${ }^{89}$ VV.AA. Guía artística de Granada y su.... Op. cit., pág. 178. 
armadura. La nave tiene coro a los pies, y con capilla mayor diferenciada la que se accede por medio de un arco toral apuntado ${ }^{90}$ que contiene resto de pintura mural ${ }^{91} \mathrm{y}$ está apoyado sobre columnas dóricas de mármol. La capilla mayor, por la cual se accede a la sacristía, fue construida en 1795 y fue realizada por el albañil Andrés Rodríguez. ${ }^{92}$

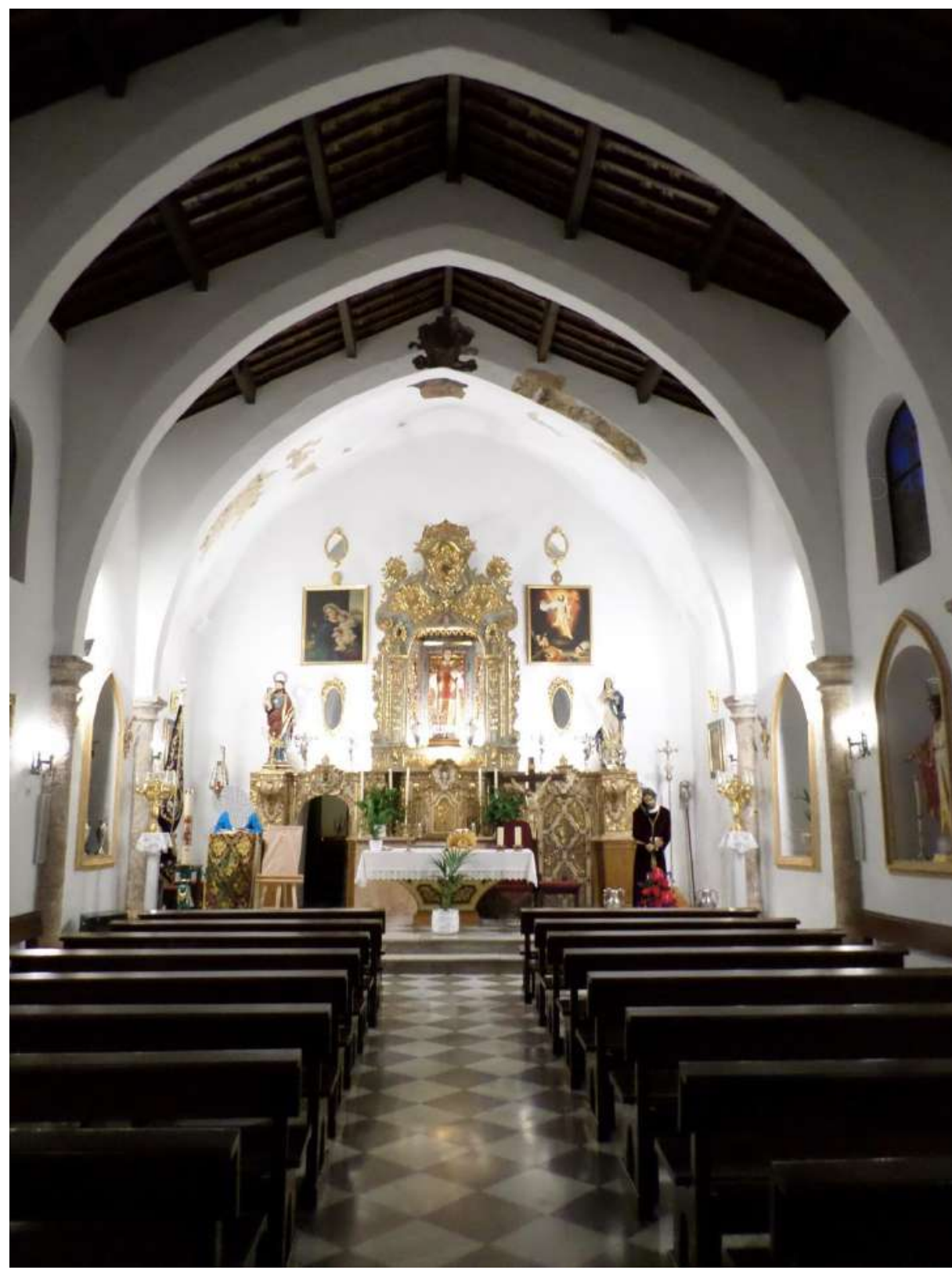

2) Nave de la iglesia.

${ }^{90}$ Este tipo de planta de nave única rectangular con arcos diafragmas con capilla mayor diferenciada responde a las tipologías de planta de iglesias mudéjares de Granada según el estudio realizado por Don Rafael López Guzmán y Don Ignacio Henares Cuéllar en:

- $\quad$ HENARES CUÉLLAR, Ignacio; LÓPEZ GUZMAN, Rafael. Arquitectura Mudéjar.... Op. cit.

${ }^{91}$ Esta pintura mural ha aparecido en sucesivas restauraciones que se han venido realizando en la Iglesia, como nos relatan sus vecinos.

${ }^{92}$ VV.AA. Guía artística de Granada y su.... Op. cit., pág. 178. 


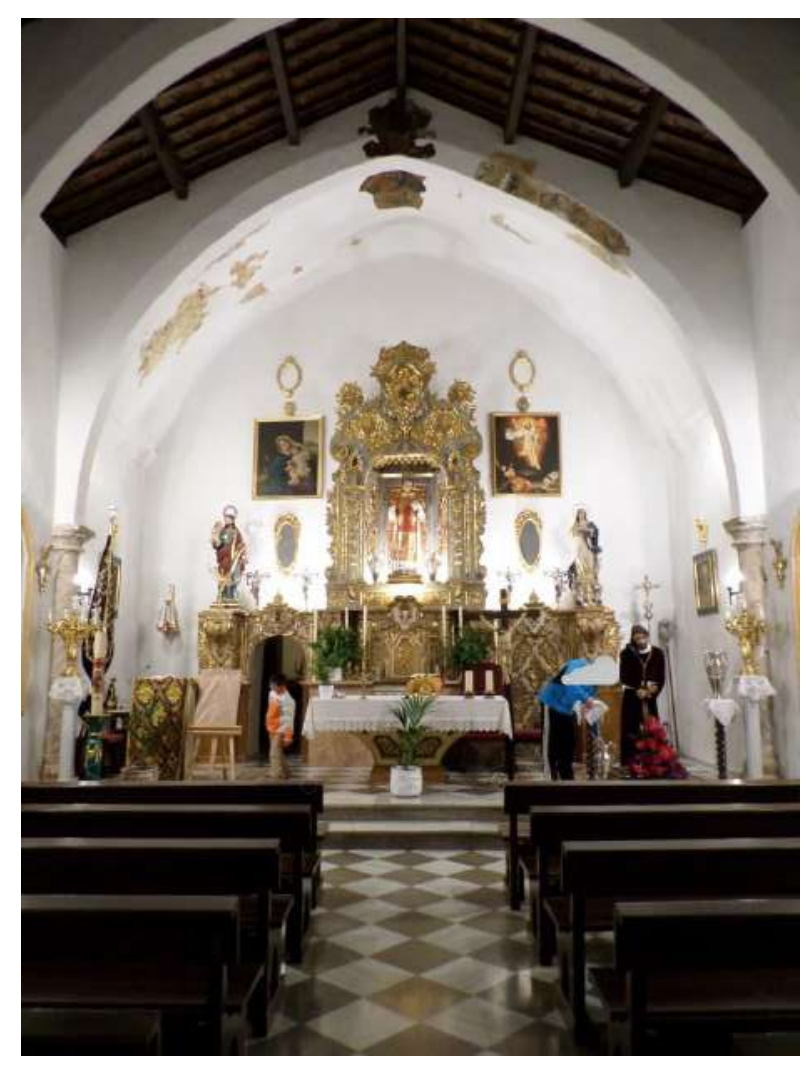

3) Capilla mayor.

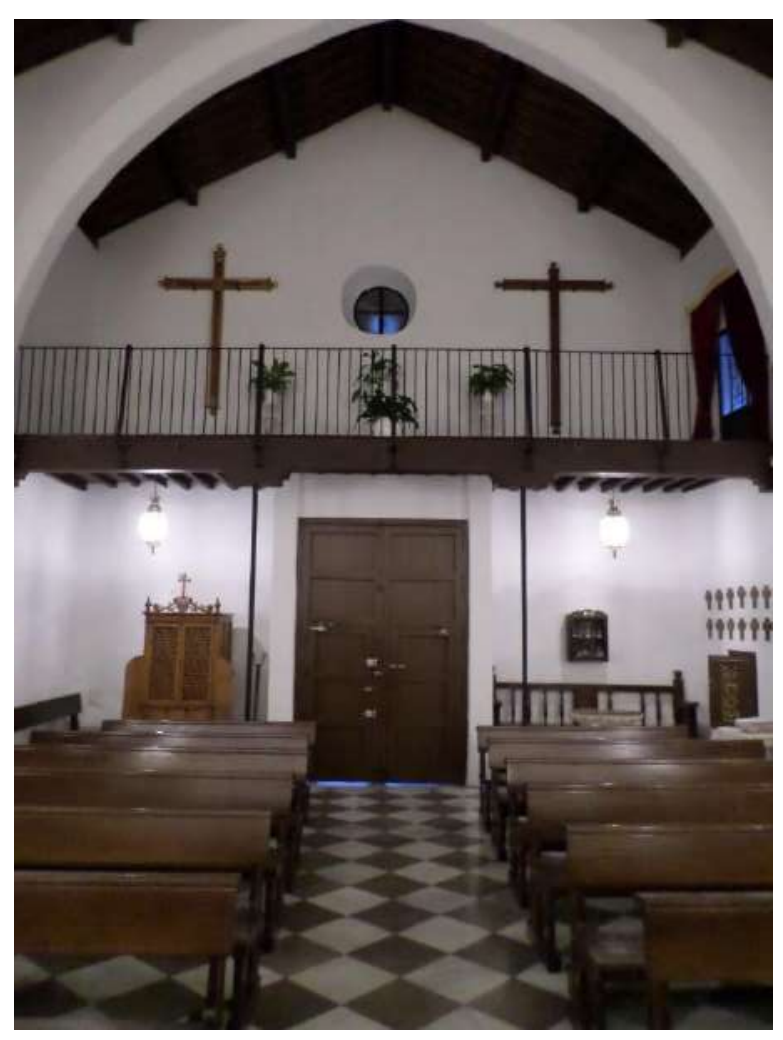

4) Coro. 
El exterior de la iglesia está construido en piedra totalmente revocado, donde debemos destacar varios elementos. En primer lugar, la fachada principal a la que se accede por un portal. Esta fachada tiene la puerta principal de acceso al templo que consta de un sencillo arco escarzano sobre el cual hay un azulejo con la imagen del Santo titular de la Iglesia, "San Lorenzo", obra moderna. También, en este exterior hemos de destacar los laterales de la iglesia en donde se perciben cinco contrafuertes realizados en piedra y revocados, aunque hemos de destacar el lateral izquierdo donde nos encontramos con un arco de medio punto de ladrillo revocado que enmarca uno de los antiguos accesos al templo.

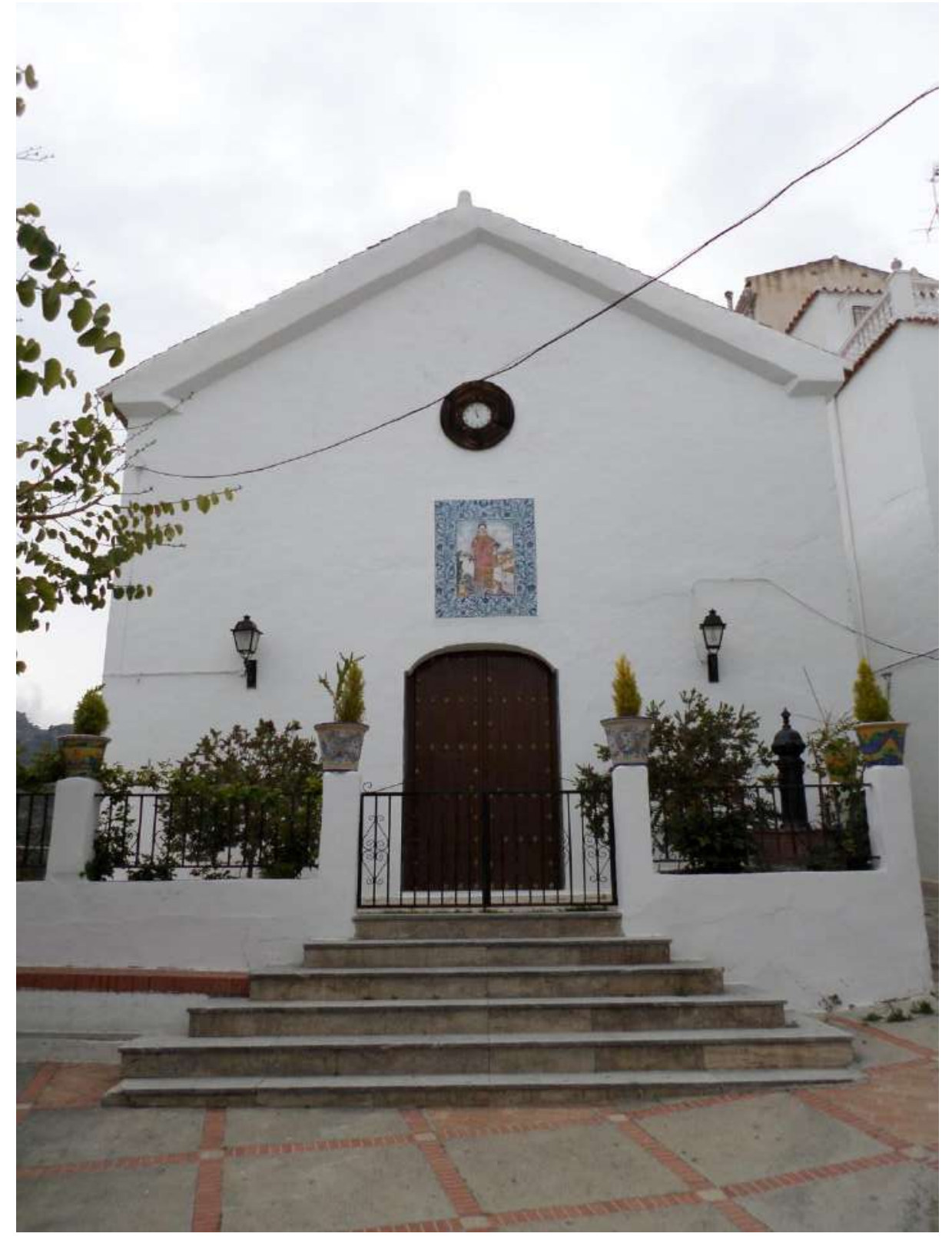

5) Fachada principal. 


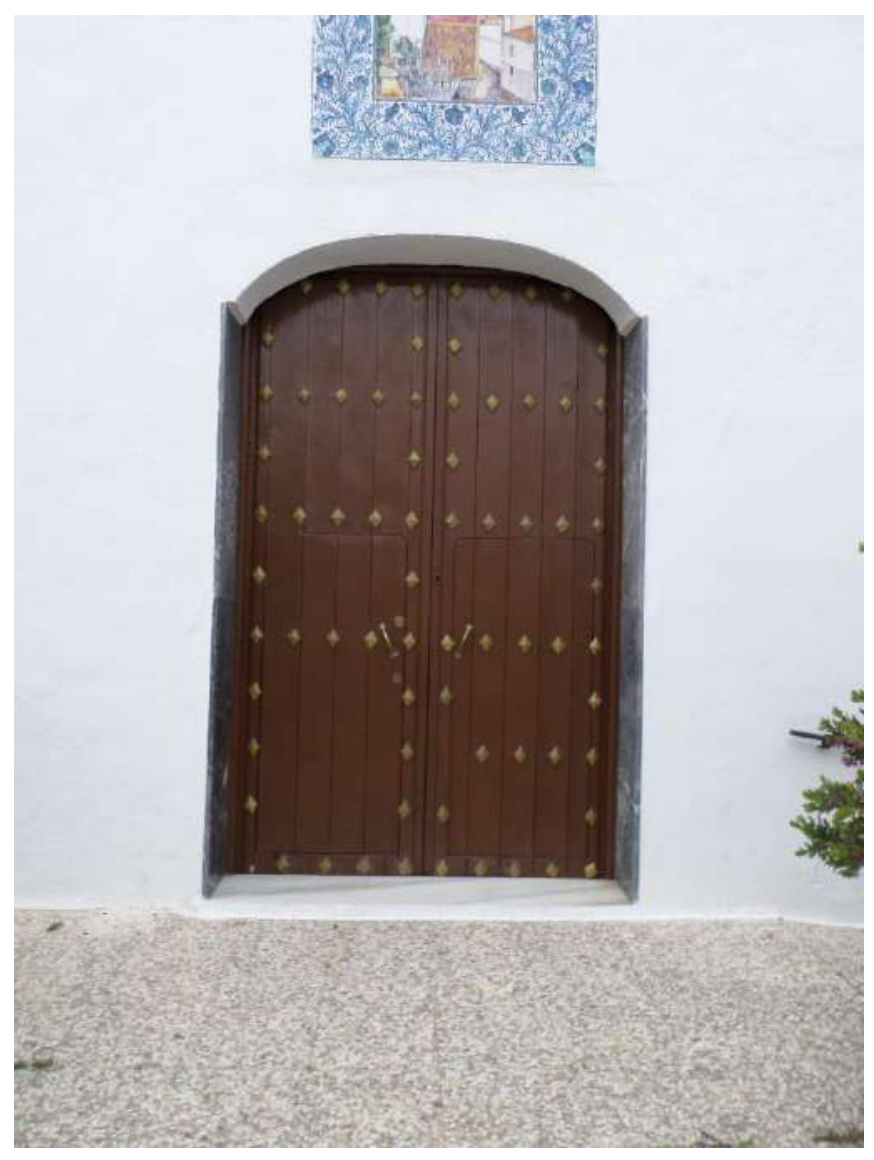

6) Portada de la fachada principal.

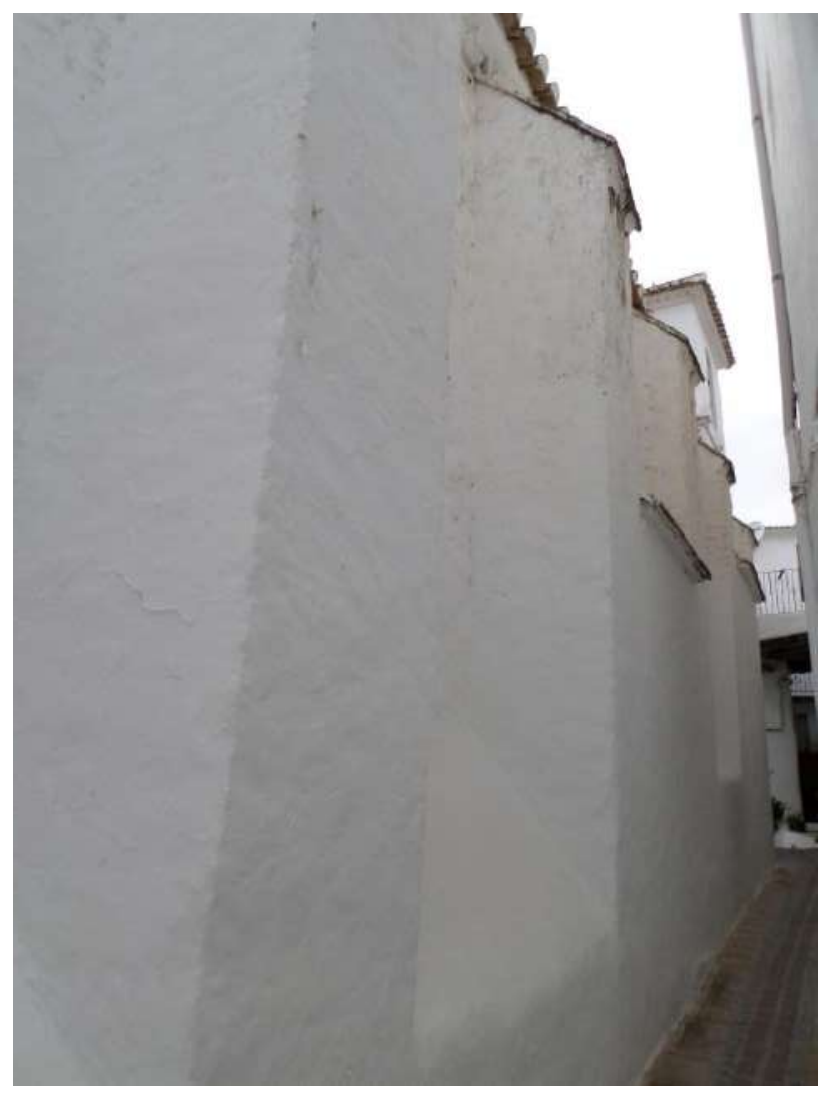

7) Lateral derecho de la iglesia. 


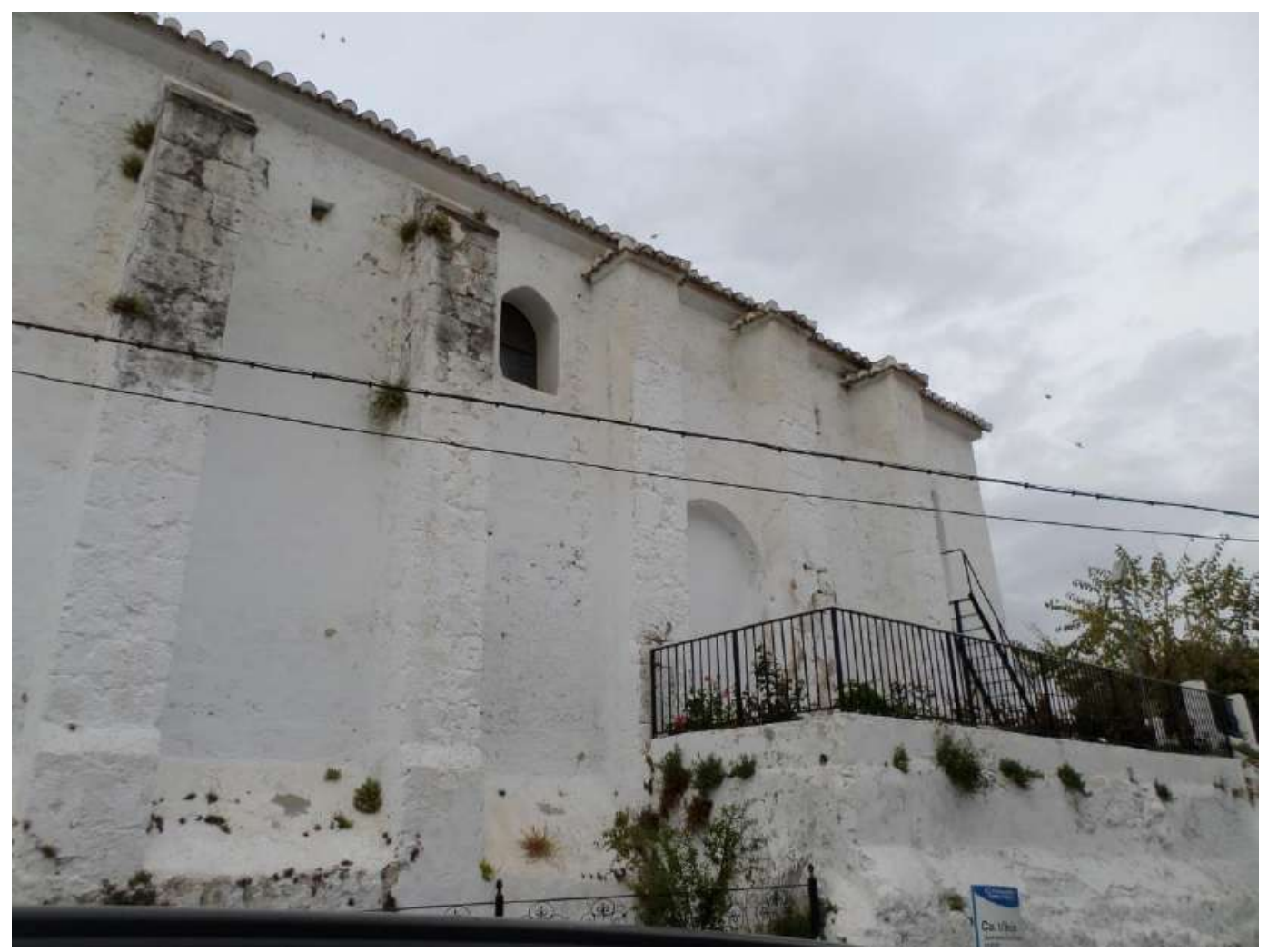

8) Lateral izquierdo de la iglesia.

En el interior de la iglesia vemos que los muros son grandes, cumplen la función de cerramiento del espacio, de descarga de los elementos superiores y dan gran sensación de solidez. La armadura de la iglesia es de colgadizo y presenta sendos estribos. Los pares de la armadura están decorados con dos alfardones hexagonales entre los que se sitúa una chilla de ocho. La armadura fue restaurada a principios de la década del $2000 .{ }^{93} \mathrm{El}$ coro está sostenido por un alfarje que contiene una única jácena sostenida por canes lobulados. Este alfarje tiene treinta jaldetas que sostienen las tablazones que no presentan ninguna decoración. El alfarje está apoyado por la jácena mediante dos columnas que hoy en día son de hierro con doble capitel de madera lobulado, pero que antes eran de manera. ${ }^{94}$ La capilla mayor está cubierta por una bóveda de cañón sostenida por una cornisa y que presenta restos de pintura mural. ${ }^{95}$

93 Testimonios de los vecinos.

94 Ibídem.

${ }^{95}$ Lo mismo que la pintura mural del arco toral, estos restos de pintura mural han ido apareciendo en las sucesivas restauraciones de la iglesia. 


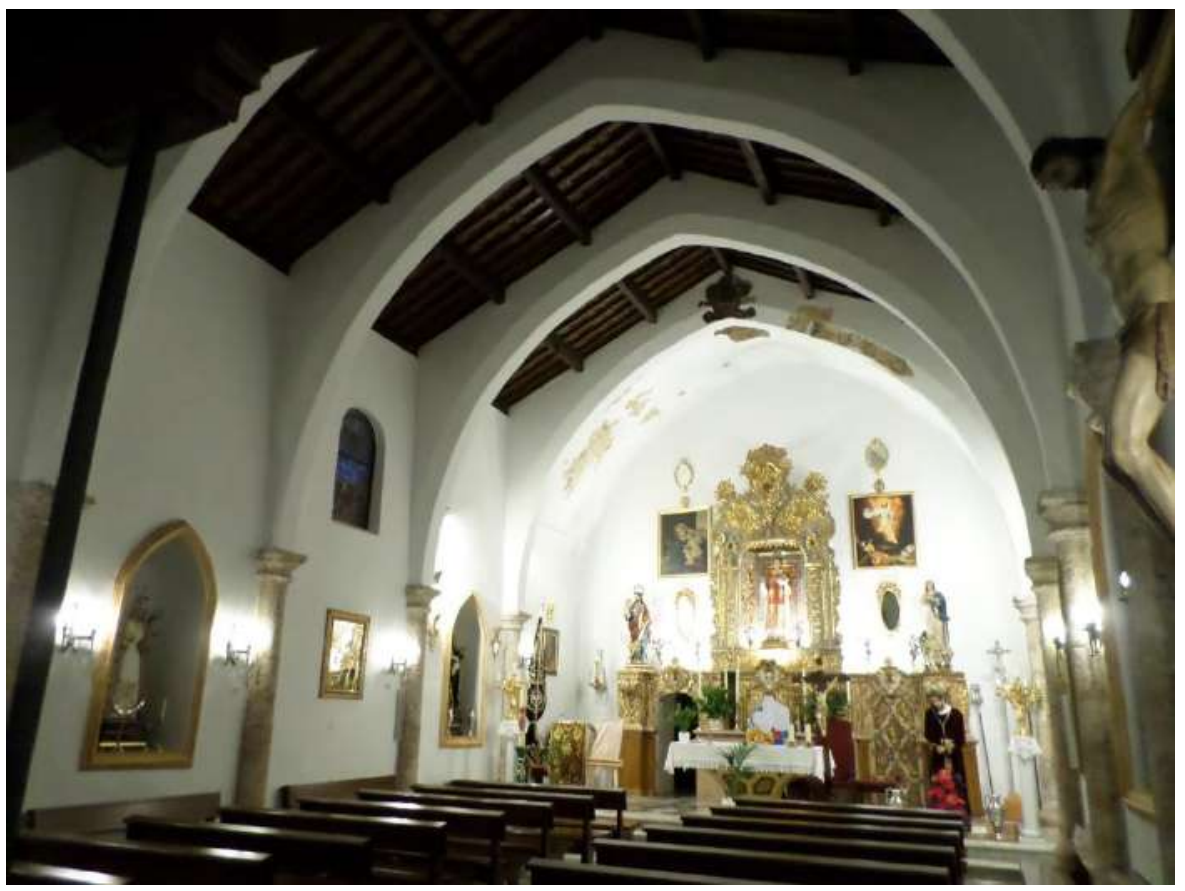

9) Arcos fajones de la nave de la iglesia.

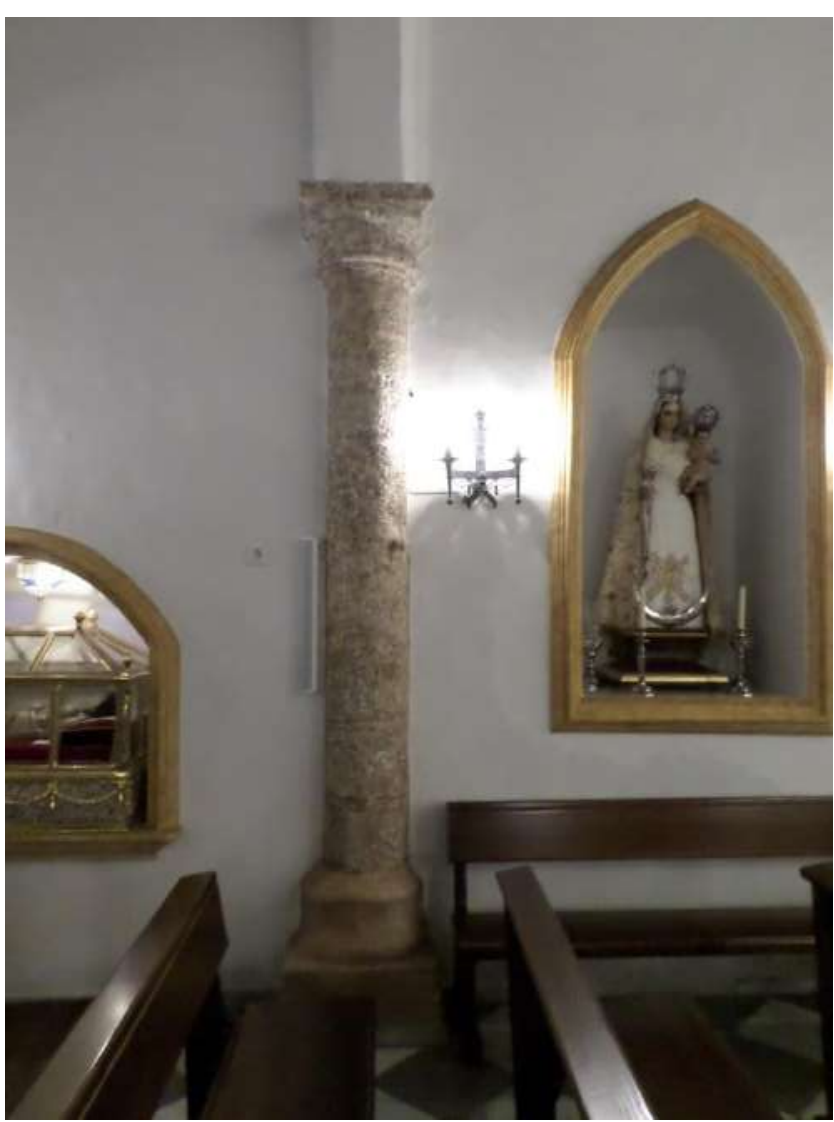

10) Columna que sostiene los arcos fajones. 


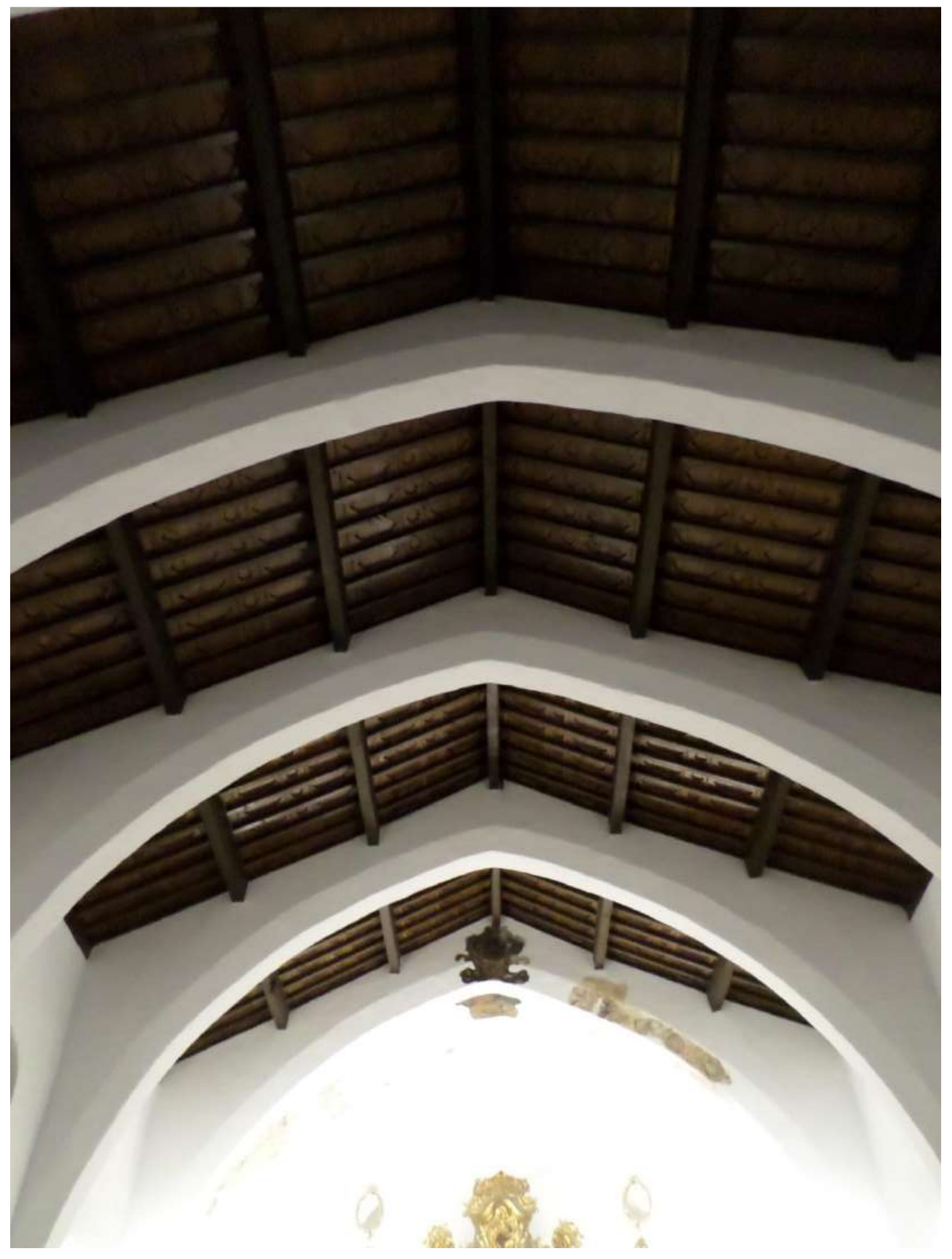

11) Armadura de la nave de la iglesia. 


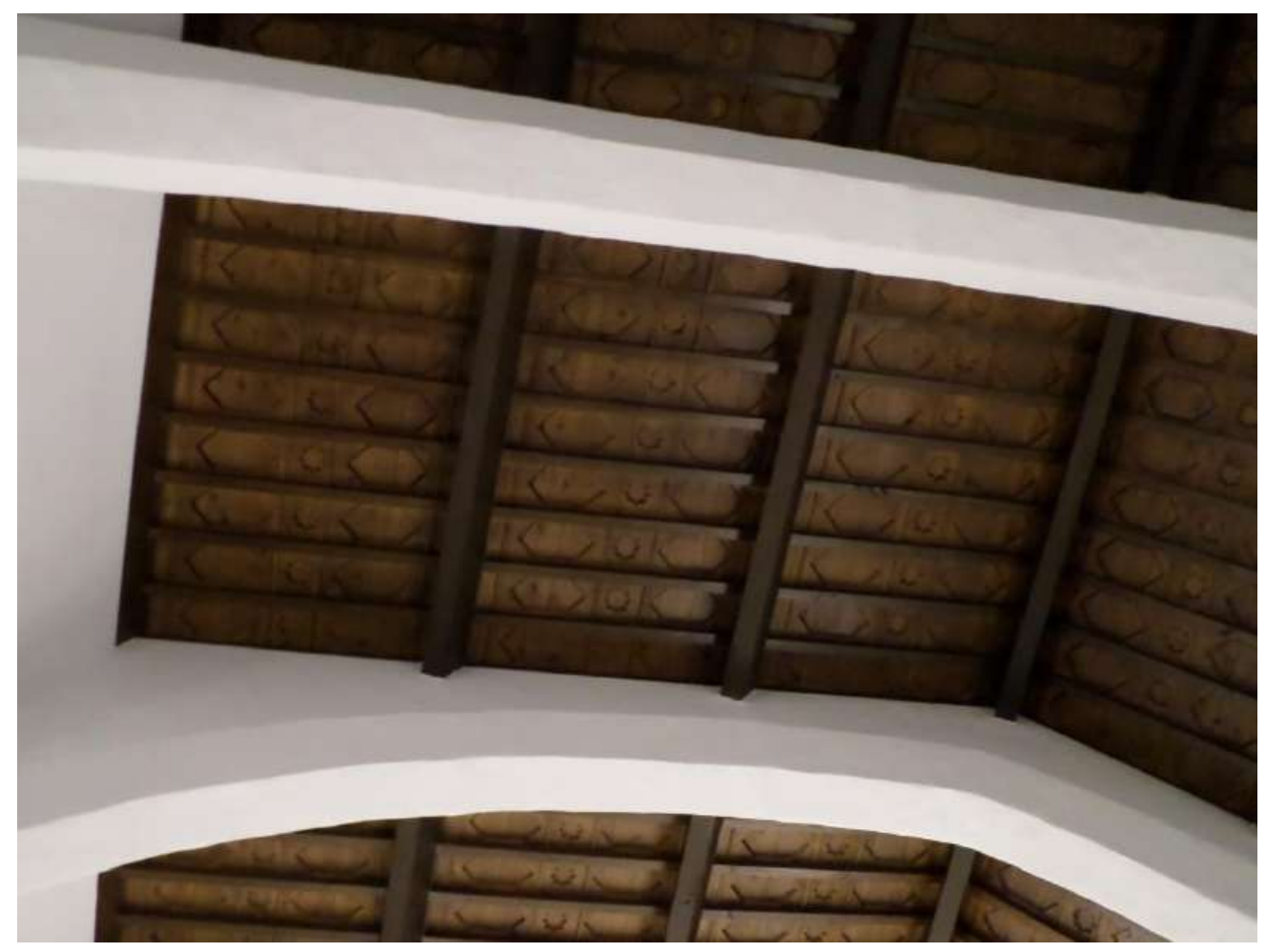

12) Detalle de los pares de la armadura.

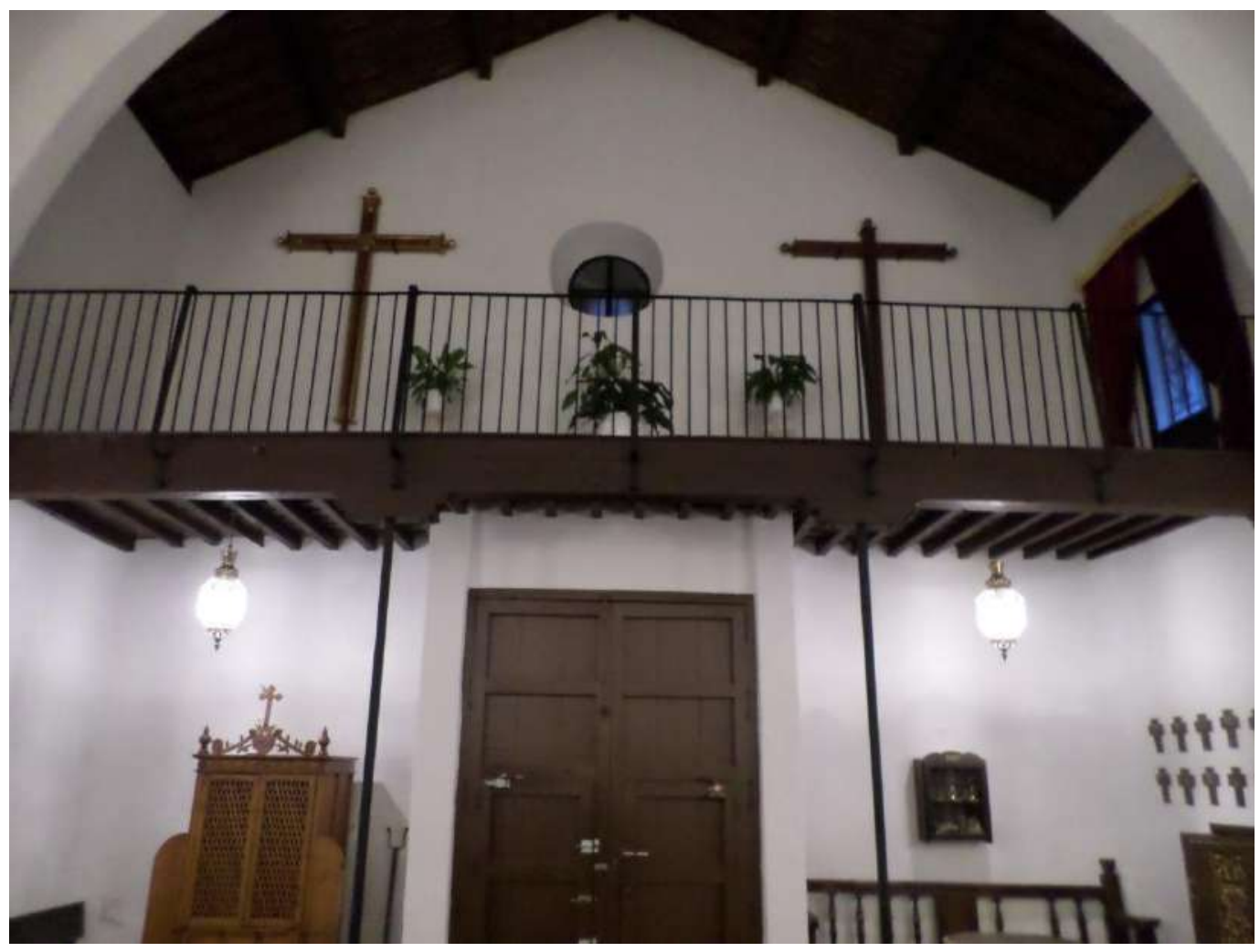

13) Alfarje. 


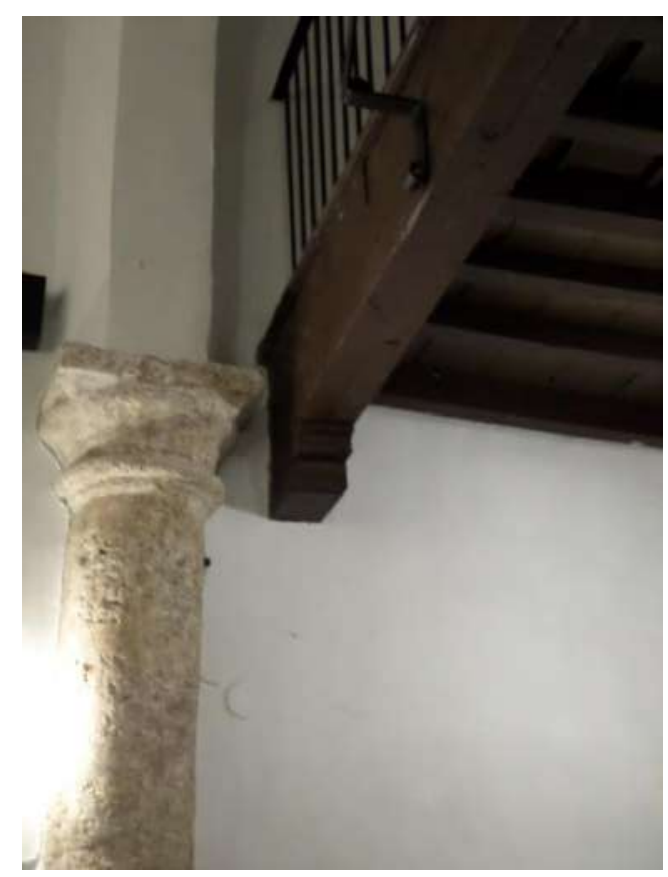

14) Can lobulado de la jácena del alfarje.

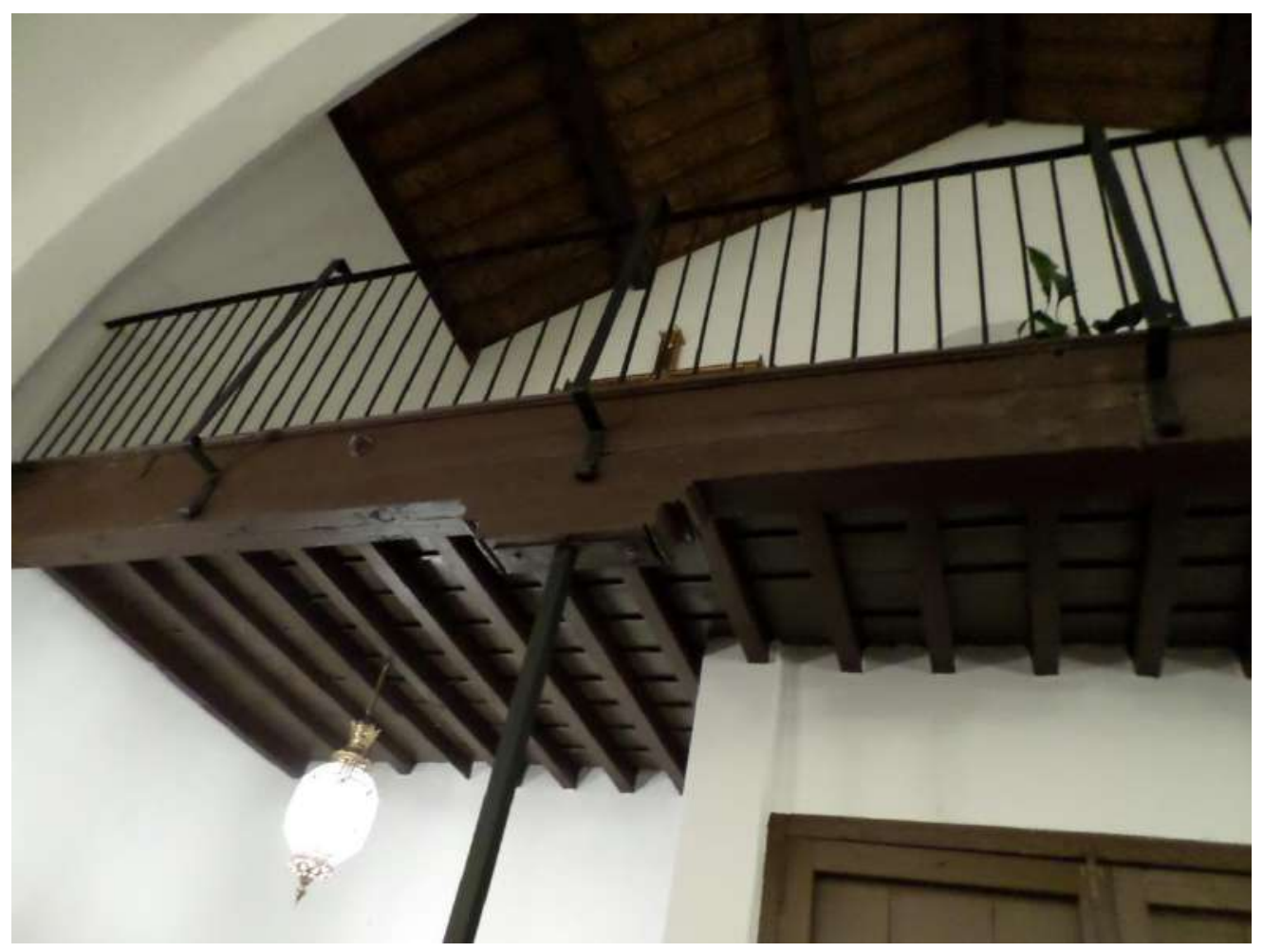

15) Detalle del alfarje. 


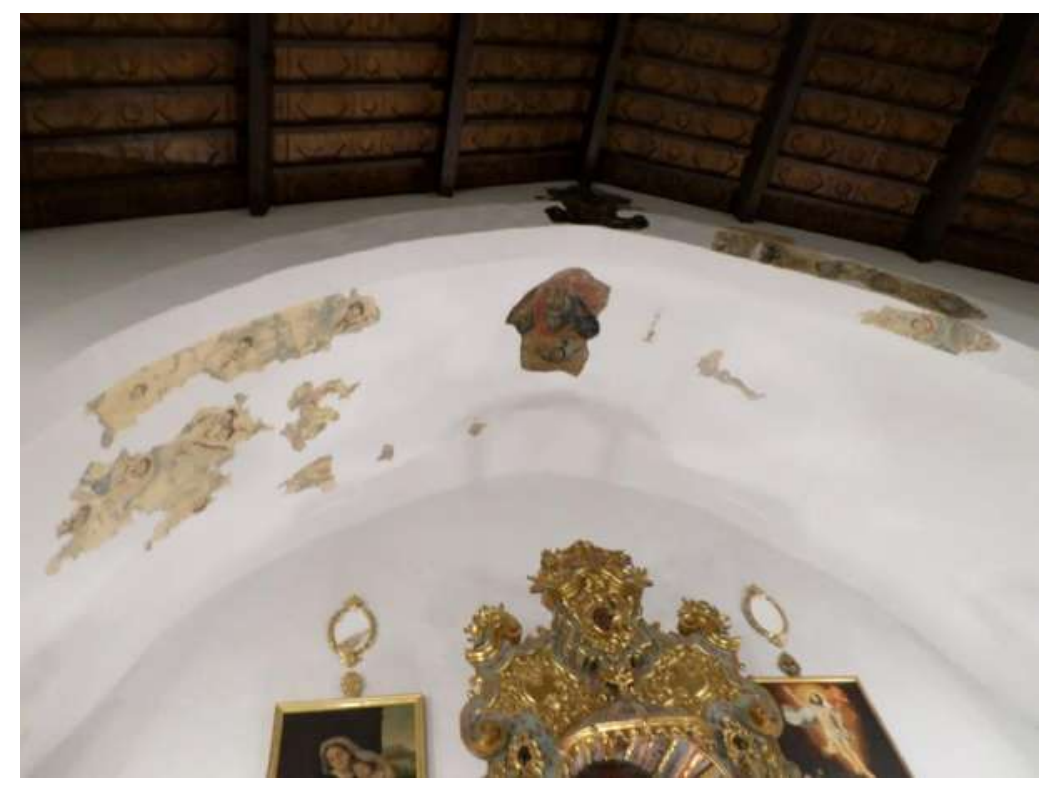

16) Bóveda de la capilla mayor.

Por último, hemos de describir la torre que se encuentra situada en el extremo NO de la iglesia y está construida también en piedra revocada. Esta torre consta de dos cuerpos divididos por una cornisa. El primer cuerpo presenta un gran paño cuadrado rehundido en sus cuatro lados, y el segundo cuerpo un vano con forma de arco de medio punto donde se sitúan las campanas.

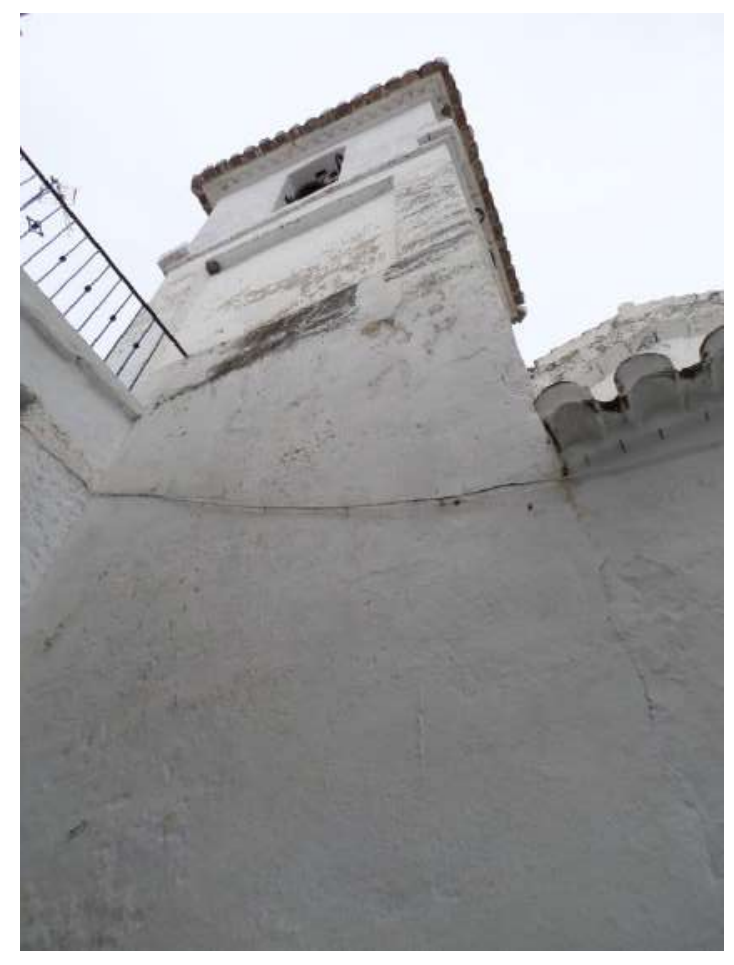

17) Torre. 


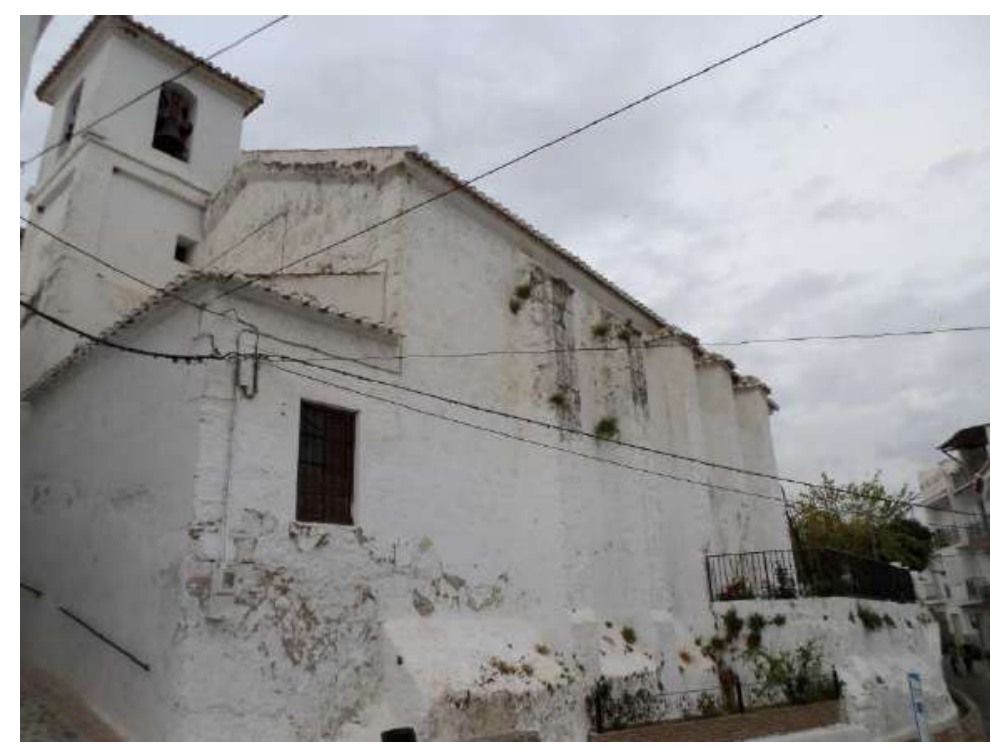

18) Vista de la torre.

Lo propiamente mudéjar de esta iglesia que hemos descrito sería el arco de ladrillo de la puerta lateral izquierda, la armadura de la nave y el alfarje, junto con su estructura espacial.

\subsection{Iglesia de Nuestra Señora de la Encarnación de Guájar Alto.}

La Iglesia de Nuestra Señora de la Encarnación de Guájar Alto fue construida a comienzo del s. XVI, aunque fue reformada en 1884 por el maestro de obras Miguel Fernández tras el terremoto de esas fechas. ${ }^{96} \mathrm{El}$ templo fue realizado en piedra, ladrillo, yeso y madera.

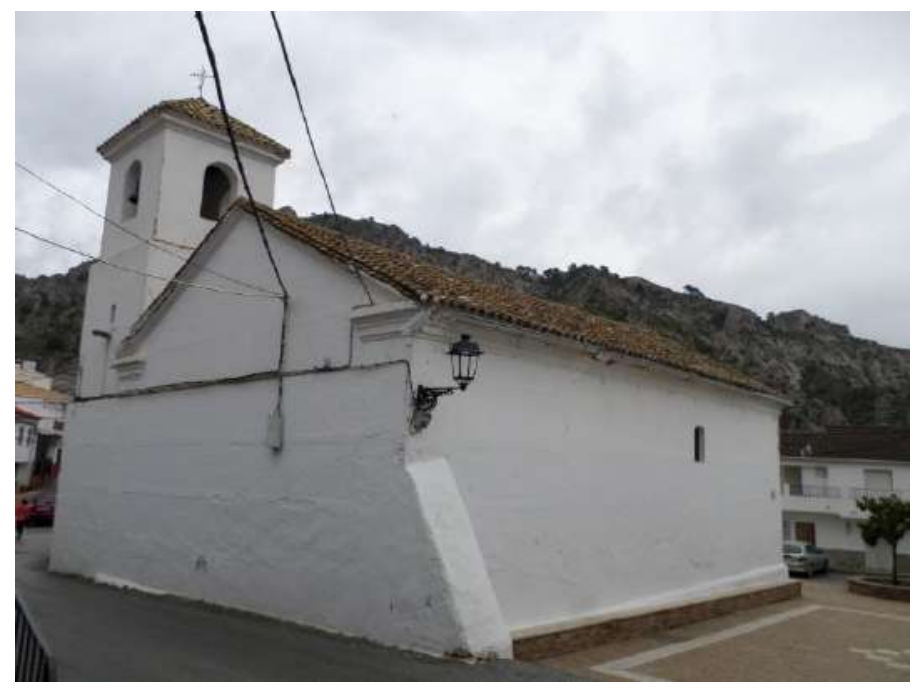

1) Iglesia de Nuestra Señora de la Encarnación de Guájar Alto.

\footnotetext{
${ }^{96}$ VV.AA. Guía artística de Granada y su.... Op. cit., pág. 179.
} 
La iglesia tiene una nave única que consta de dos arcos diafragma apuntados que contiene en la parte superior vigas de madera y están sostenidos por columnas dóricas, cuyos capiteles están dorados, con capillas entre contrafuertes, coro a los pies, capilla mayor diferenciada a la que se accede a través de un arco toral de medio punto ${ }^{97}$ y a través de la cual se accede a la sacristía.

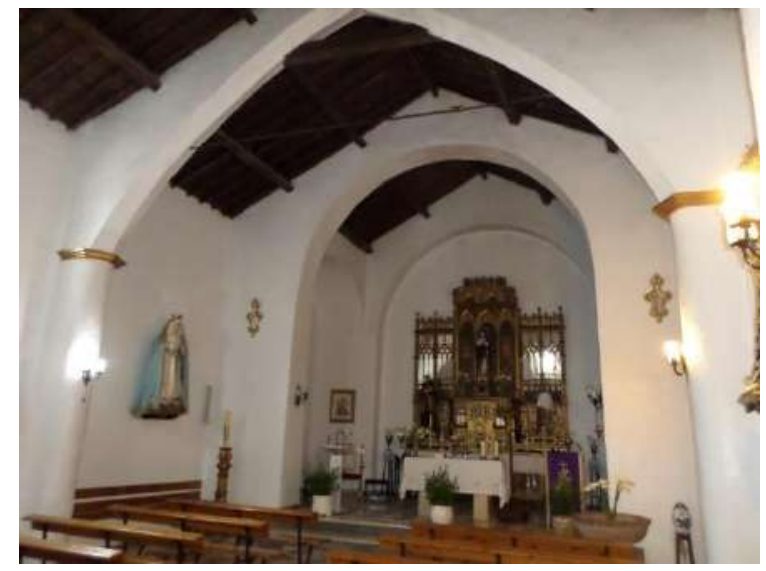

2) Vista de la nave de la iglesia desde el lateral derecho.

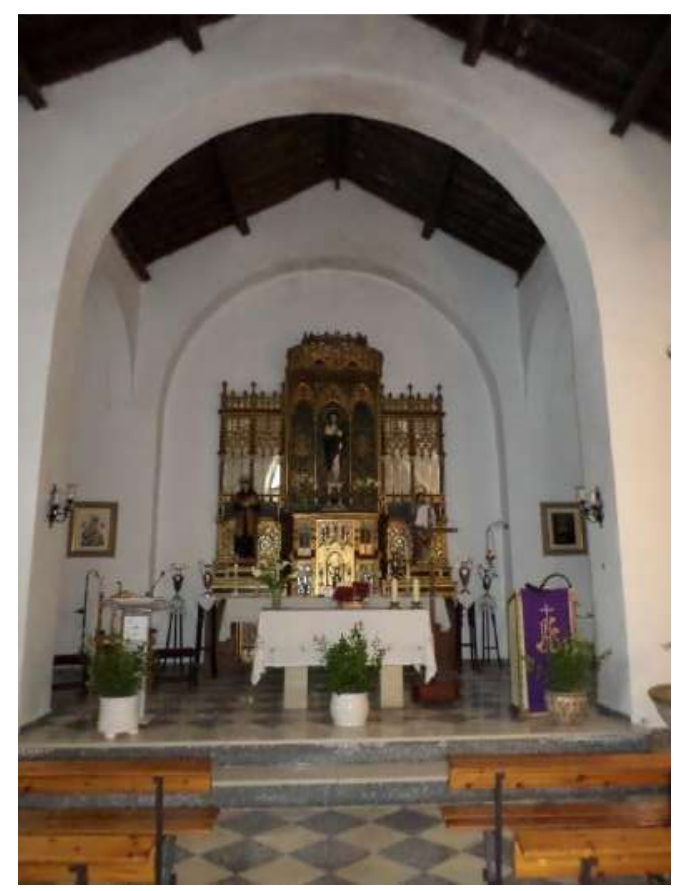

3) Capilla mayor.

${ }^{97}$ Este tipo de planta de nave única rectangular con arcos diafragma, capillas laterales entre contrafuertes y capilla mayor separada por un arco toral, responde a las tipologías.... Op. cit. 


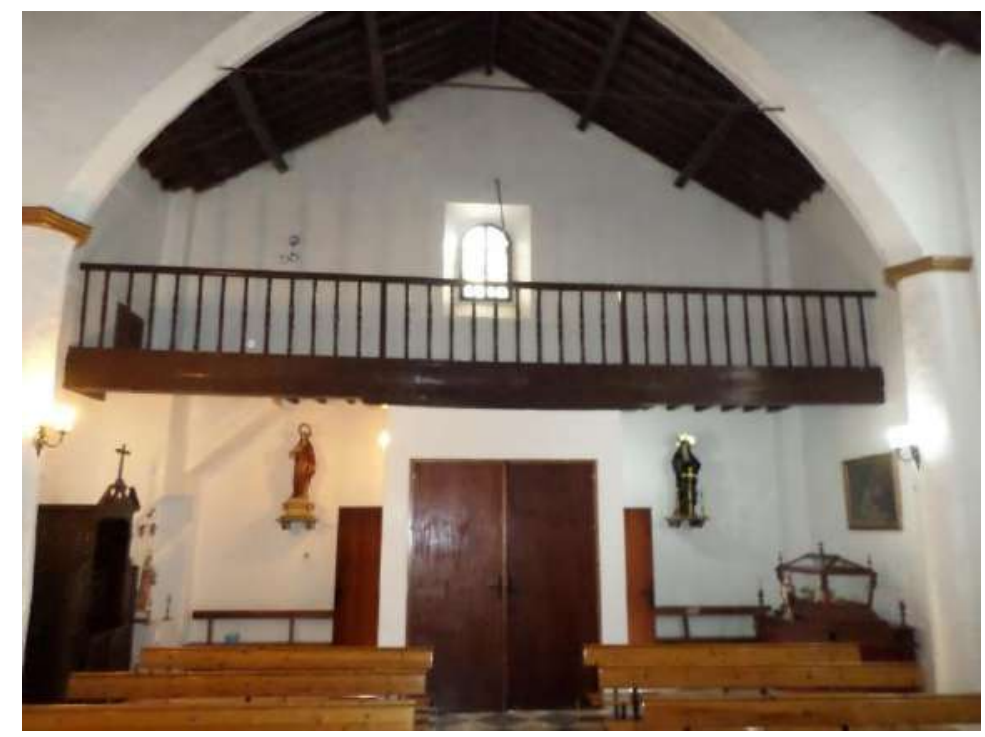

4) Coro.

El exterior está totalmente revocado, pero antes de la Guerra Civil se percibían las cintas de yeso y cajones de mampostería en todas sus fachadas. ${ }^{98}$ La fachada principal consta de la puerta de acceso al templo que está enmarcada por un arco de medio punto sostenido por dos polares dóricos. Este arco y estos pilares son de ladrillo, y estaban así hasta la reforma que se hizo después de la gran obra de restauración de después de la Guerra Civil, estando hoy revocados, ${ }^{99}$ y encima de ellos aparecen una hornacina, coronando el conjunto un vano con forma de arco de medio punto que ilumina interiormente el coro.

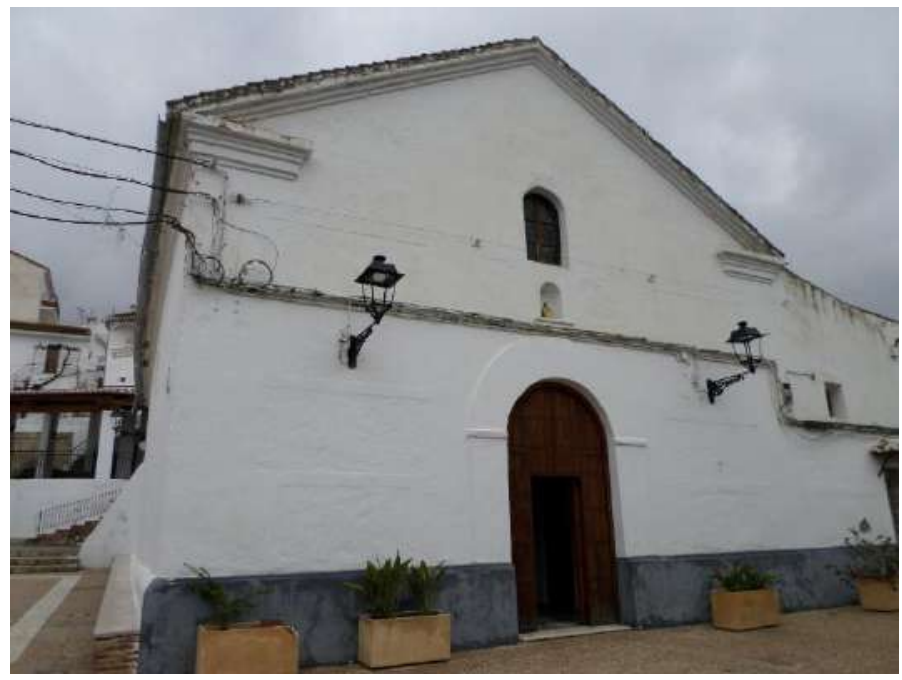

5) Fachada principal.

98 Según nos testimonian los vecinos.

${ }^{99}$ Lo sabemos por testimonios de los vecinos. 


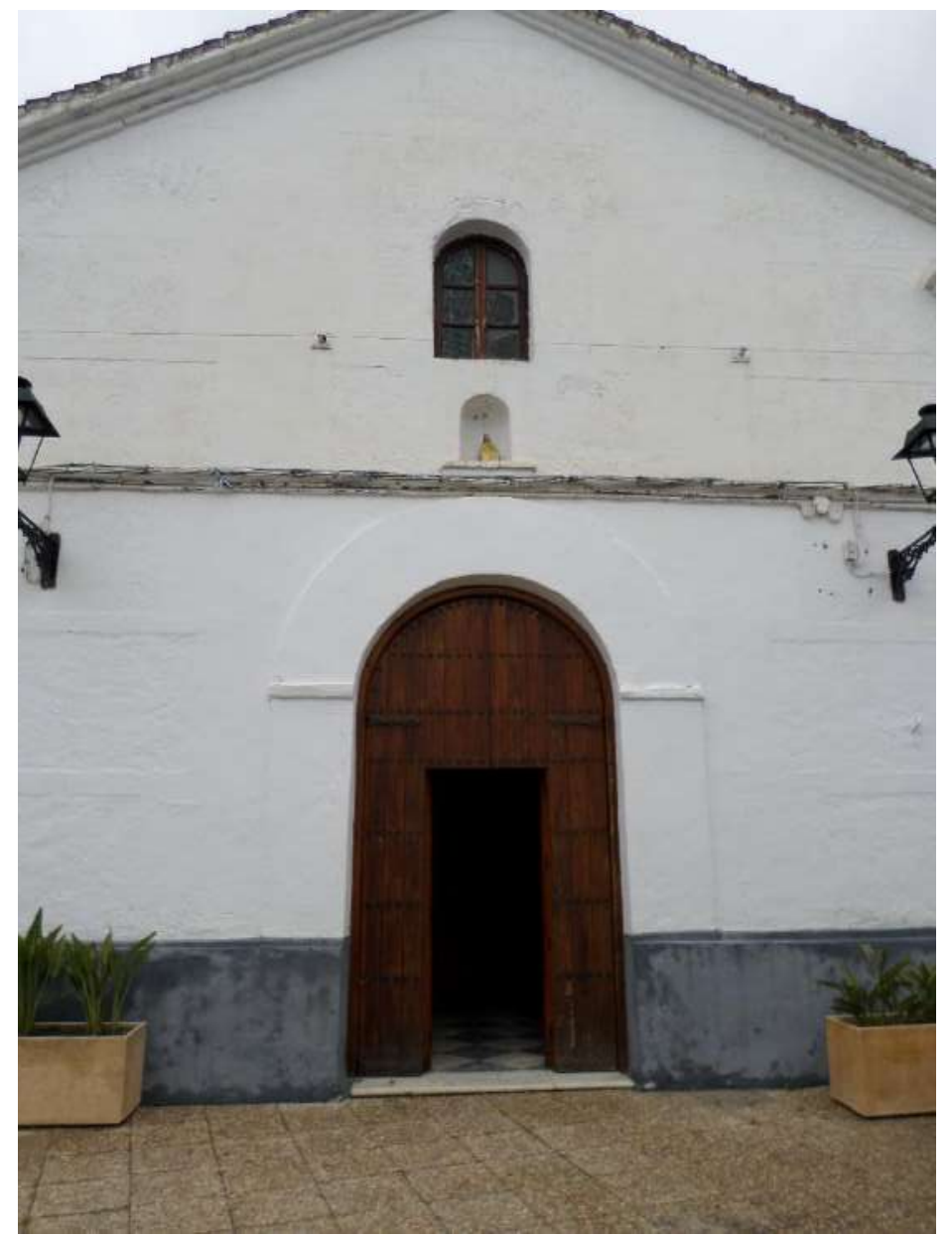

6) Portada de la fachada principal.

En el interior, hemos de decir en primer lugar, que los muros son de cerramiento y cumplen la función de descarga de los elementos superiores, y dan gran sensación de solidez. Sobre estos arcos diafragma de la nave y sobre el arco toral está colocada la armadura de la iglesia. Esta armadura no solo cubre la nave de la iglesia, sino también la capilla mayor y el coro, y presenta estribos que sostienen los pares, los cuales no tienen ningún tipo de decoración, siendo por ello una armadura llana. La primitiva armadura fue realizada en 1534 por el carpintero Francisco Rodríguez, y fue sustituida en 1884 cuando se reconstruyó el templo, ${ }^{100}$ y ésta, a su vez, se reconstruyó tras los destrozos acaecidos en la Guerra Civil junto con el alfarje. ${ }^{101}$ El coro está sostenido por un alfarje que consta de una única jácena sin canes y dividido por el sotocoro que es de hormigón, pero primitivamente era de madera. Este alfarje estaba sostenido por la jácena mediante dos columnas de madera que hoy han desaparecido de las que quedan los capiteles

${ }^{100}$ VV.AA. Guía artística de Granada y su.... Op. cit., pág. 179.

${ }^{101}$ Lo sabemos por testimonios de los vecinos. 
lobulados. ${ }^{102}$ El alfarje tiene dieciséis jaldetas sobre las que se colocan las tablazones y estas no presentan ningún tipo de decoración; las jaldetas de la parte derecha están dispuestas en horizontal y vertical. El acceso al coro, que vemos ahora de cemento, también era de madera. La capilla mayor presenta tres arcos de medio punto en sus tres lados.

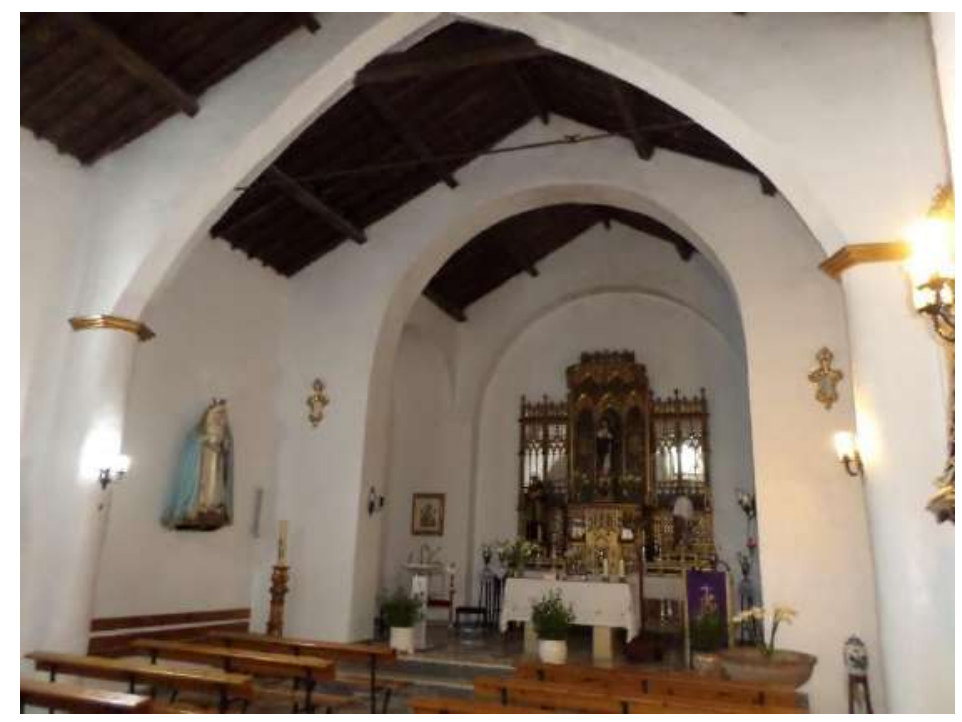

7) Uno de los dos arcos fajones de la nave de la iglesia.

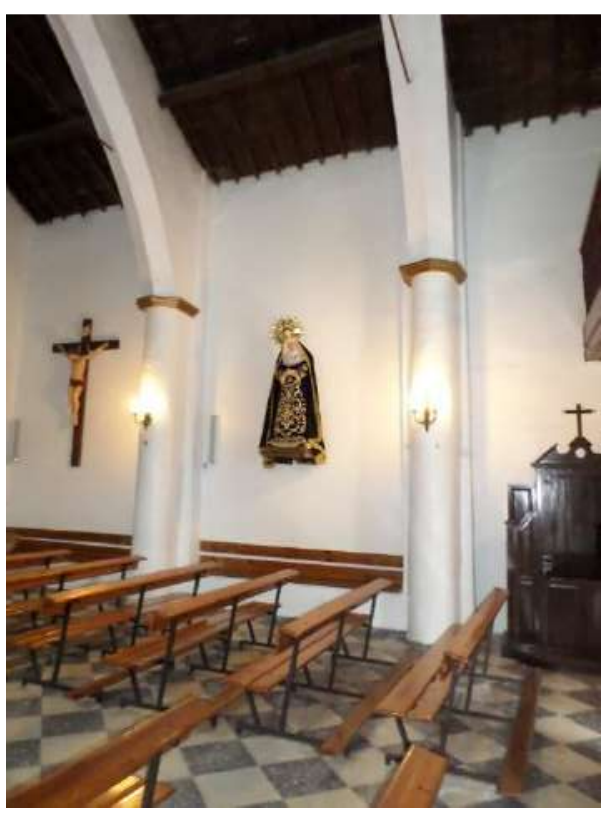

8) Columnas que sostienen los arcos fajones.

102 Ibídem. 


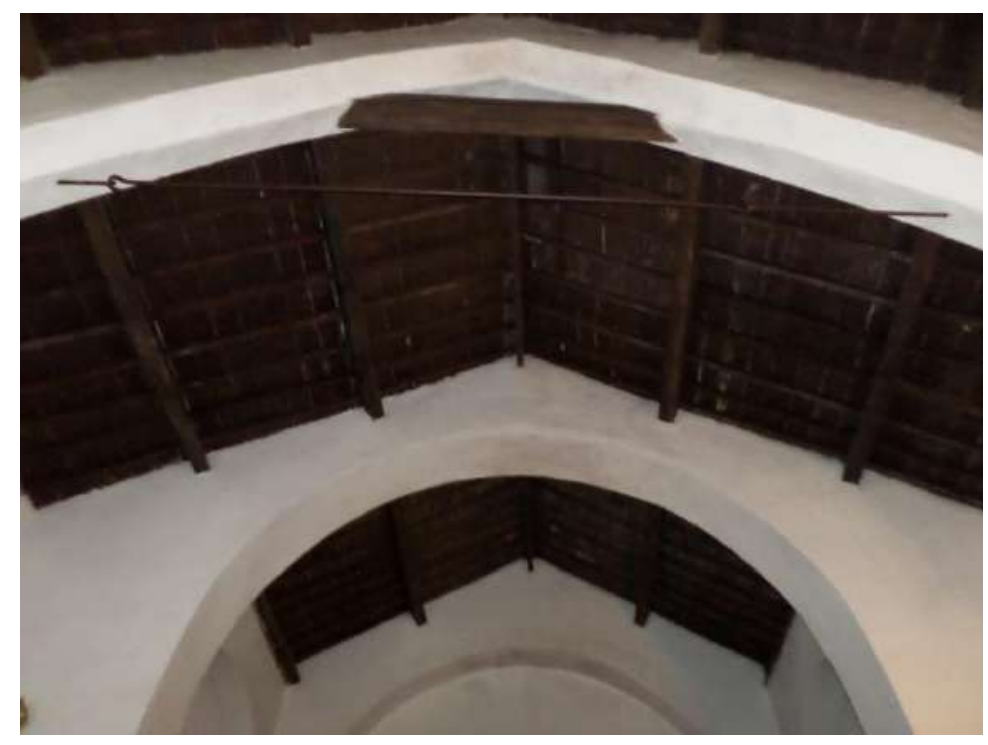

9) Armadura de la nave de la iglesia.

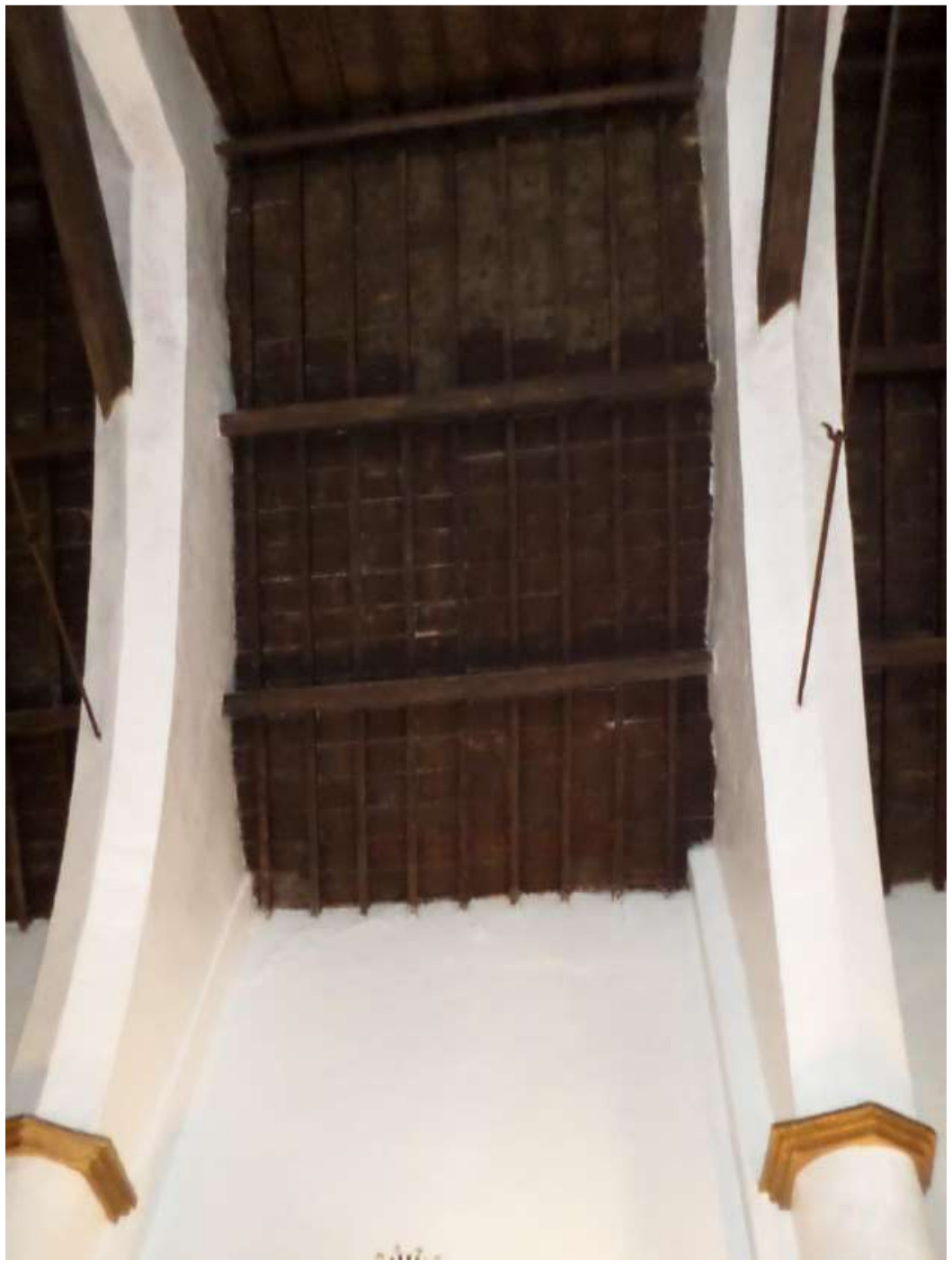

10) Detalle de los pares de la armadura. 


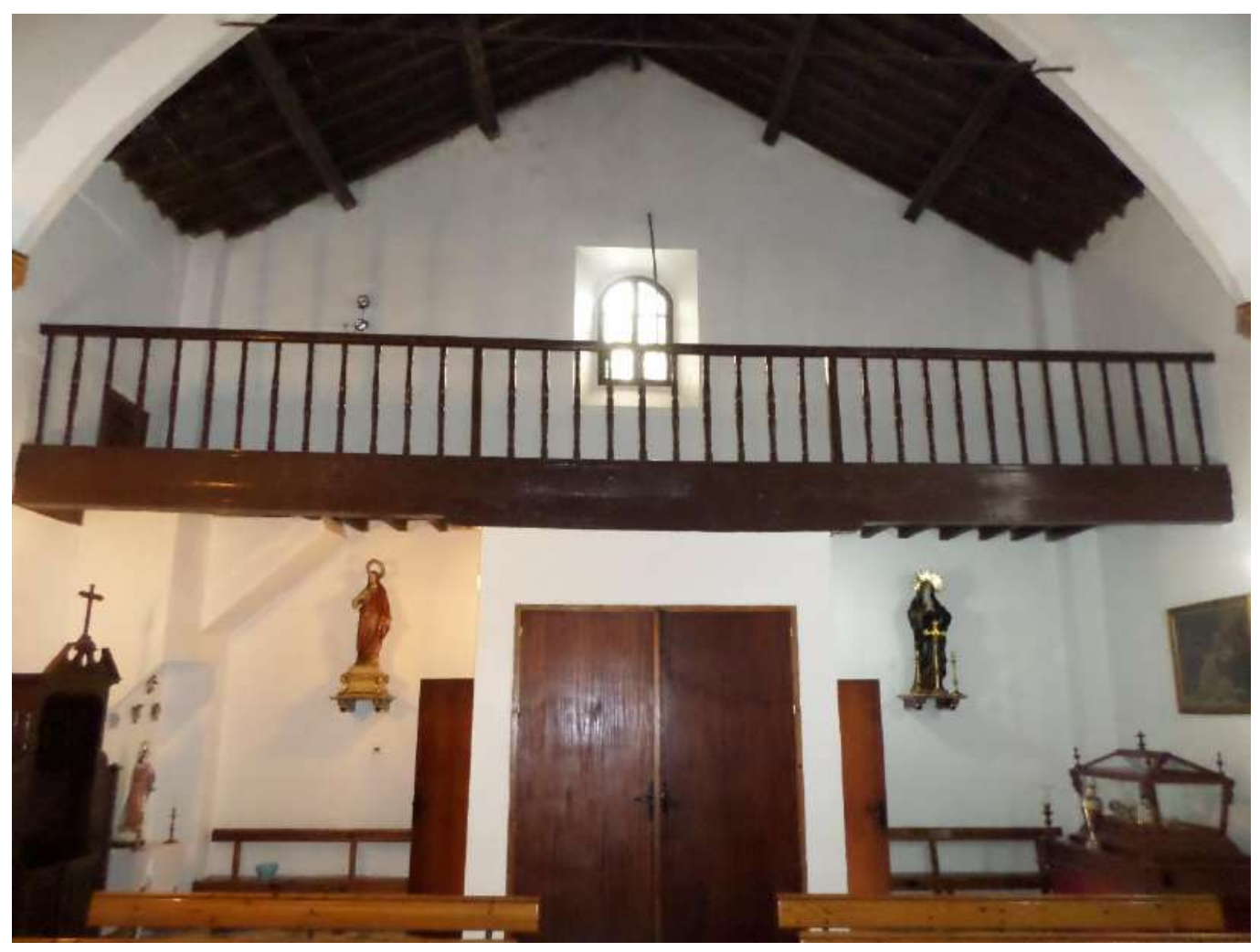

11) Alfarje.

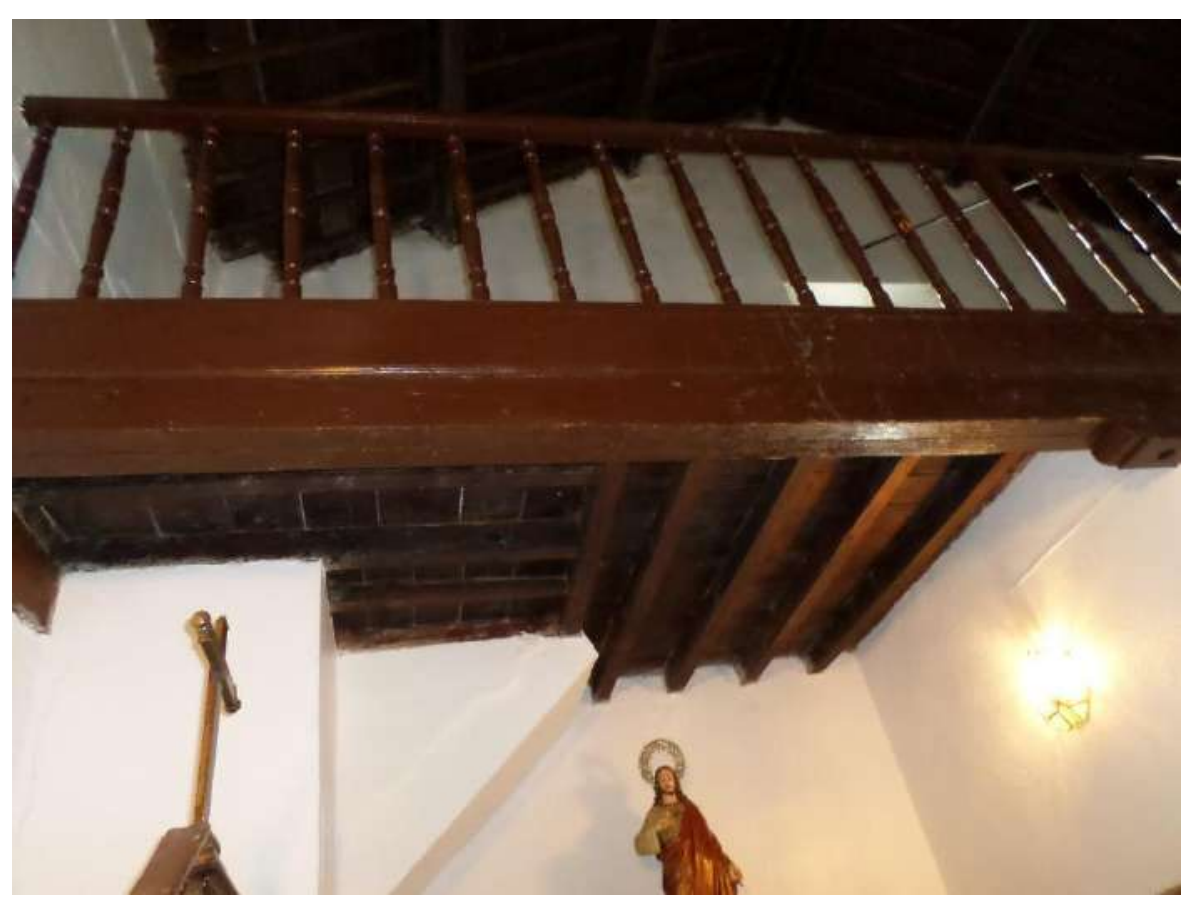

12) Detalle del alfarje. 


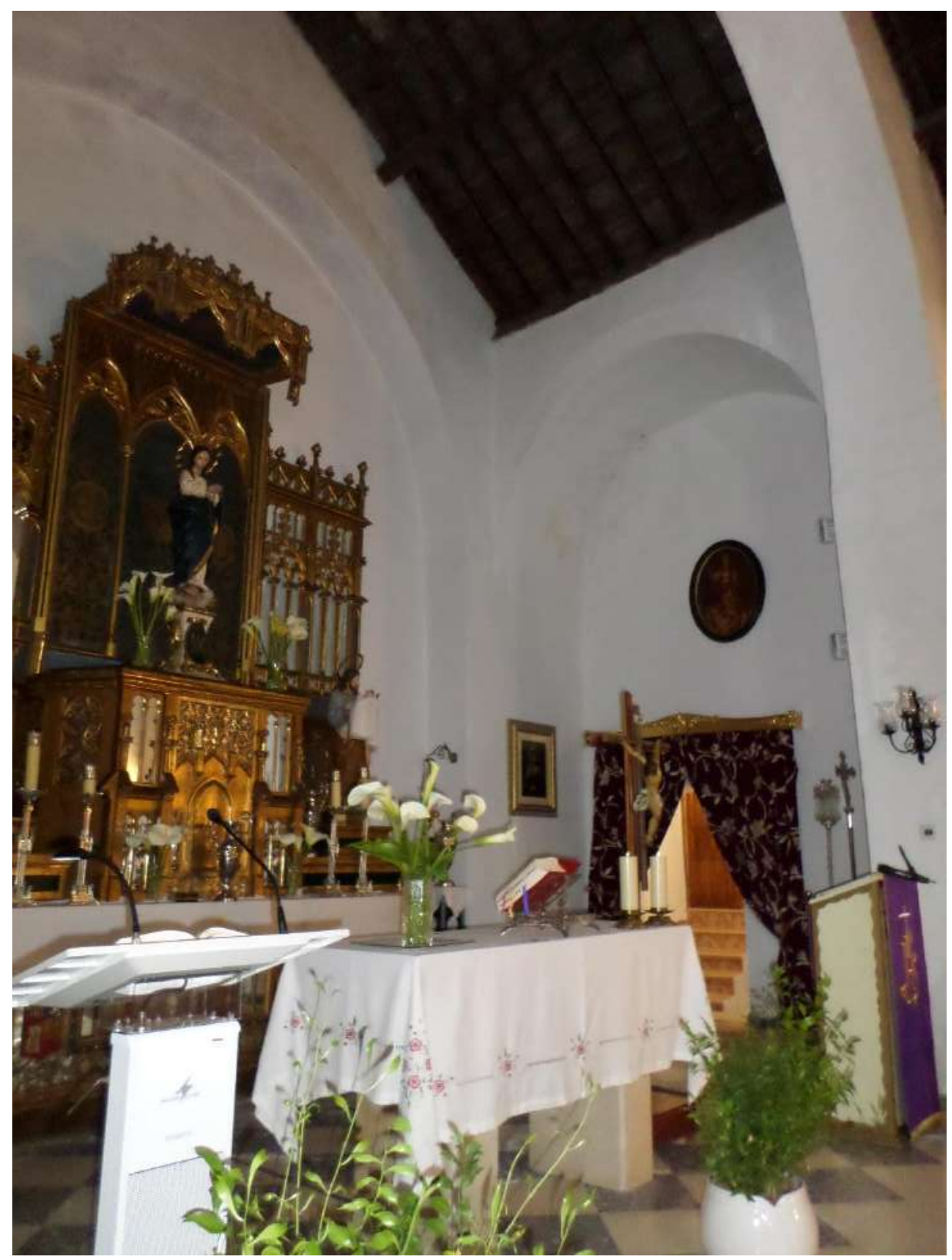

13) Detalle de la capilla mayor con los arcos que aparecen en ella.

La torre, que se encuentra situada en el lado NO de la iglesia, está revocada también, pero está construida en cintas de yeso y cajones de mampostería y presenta tres cuerpos. El primer y segundo cuerpo tiene pequeños vanos a modo de troneras, y el tercero cuerpo presenta vanos con forma de arcos de medio punto donde se sitúan las campanas. 


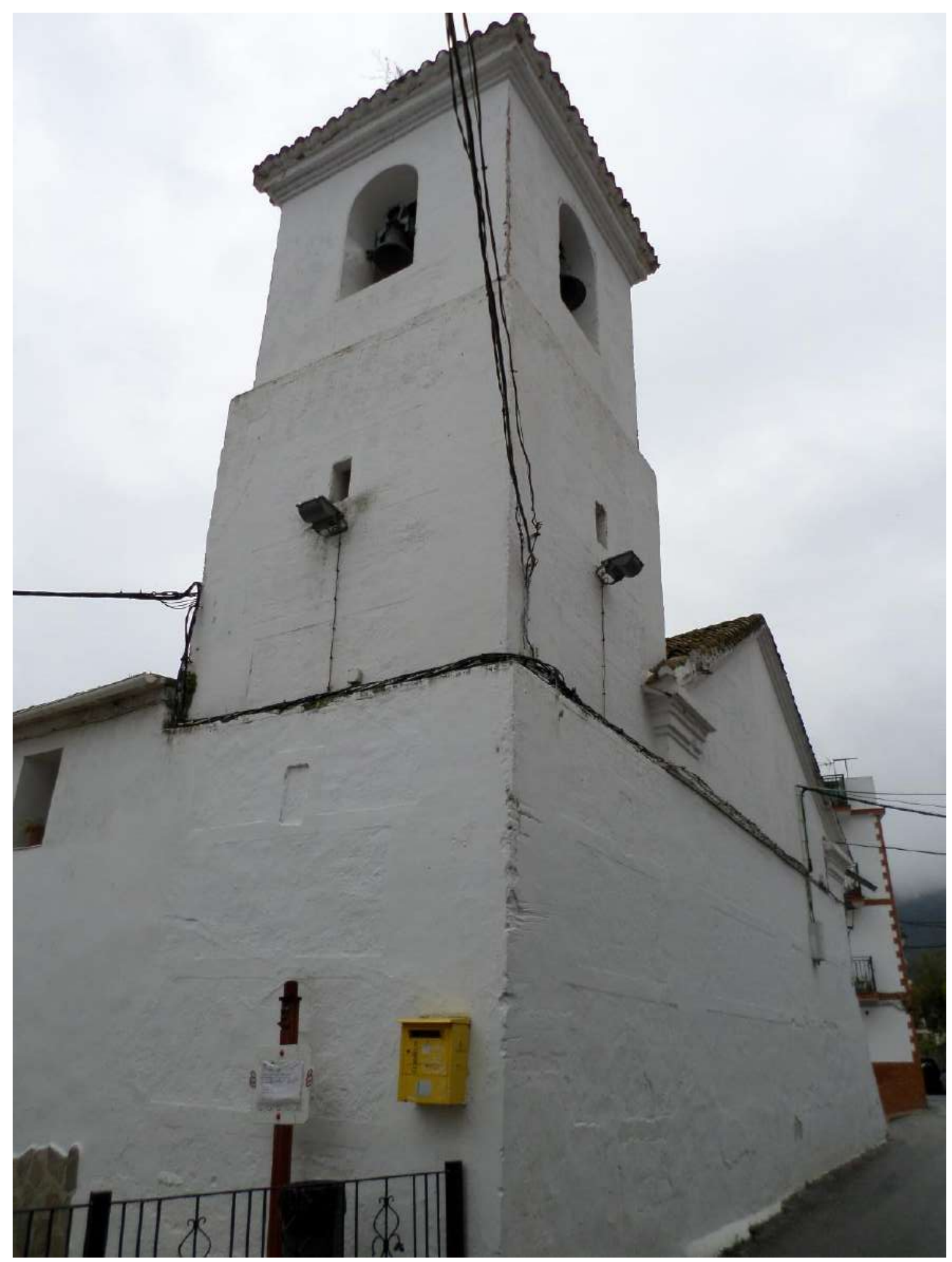

14) Torre. 


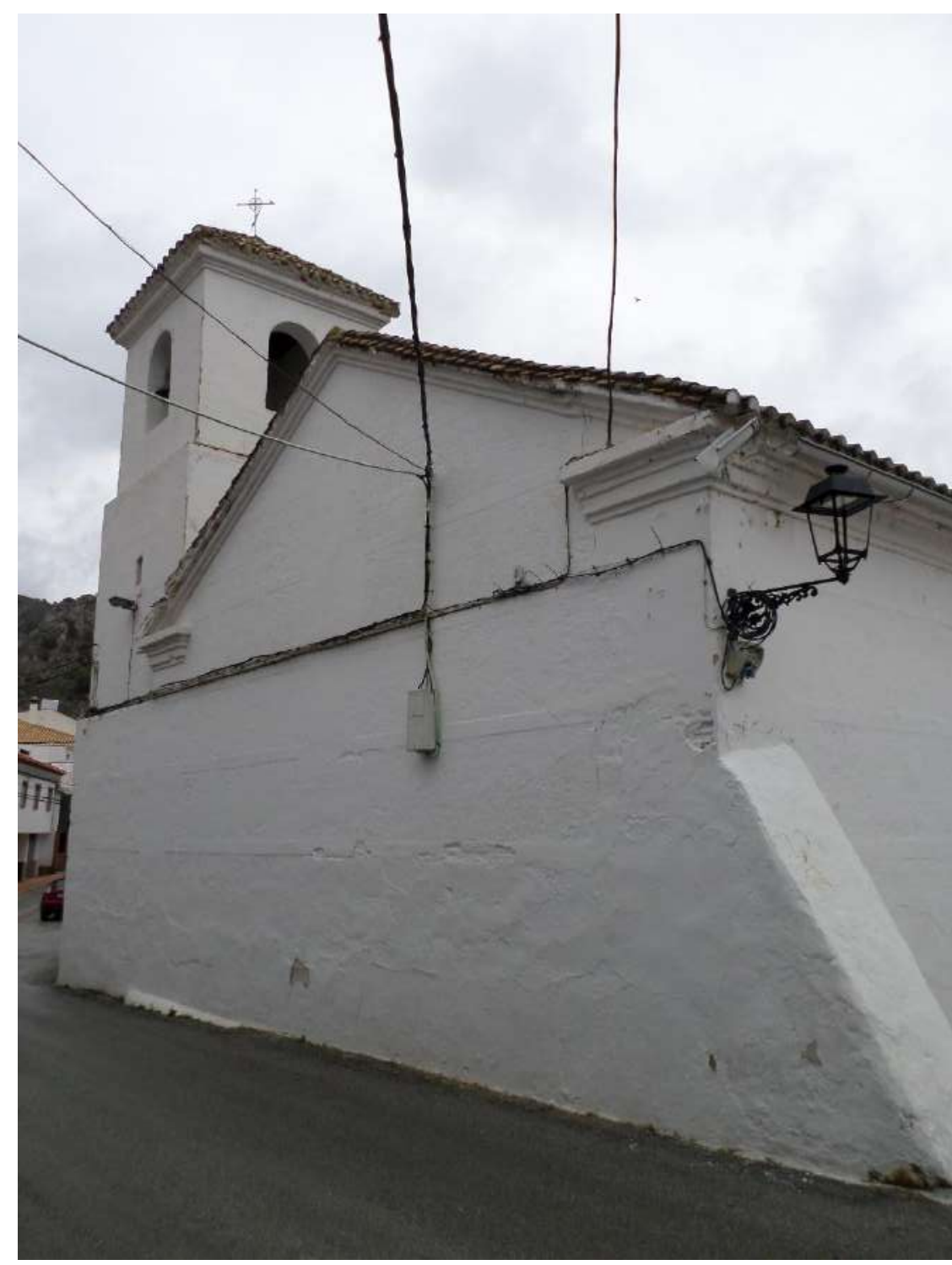

15) Vista de la torre.

De la iglesia que hemos descrito, la parte mudéjar sería, en primer lugar: la gran estructura espacial. Del exterior, las extensas paredes con cintas de yeso y cajones de mampostería, junto con la portada principal de ladrillo, y la torre; y del interior, la armadura y el alfarje, que, aunque han sido reconstruido nos permiten apreciar el mudéjar en la iglesia.

\subsection{Iglesia Mayor Parroquial de la Encarnación de Motril.}

La Iglesia Mayor Parroquial de la Encarnación de Motril es un templo que se empezó a construir a comienzos del s. XVI y que ha tenido numerosas ampliaciones y transformaciones a lo largo de los siglos sobre un promontorio elevado que ocupaba la Mezquita Aljama Alçijara. El templo es concebido como una iglesia fortaleza que sirvió no solo como lugar de culto sino también como refugio ante los continuos ataques de 
los piratas berberiscos del Norte de África. ${ }^{103}$ Los principales materiales de construcción de esta iglesia son la piedra, el ladrillo y el yeso.

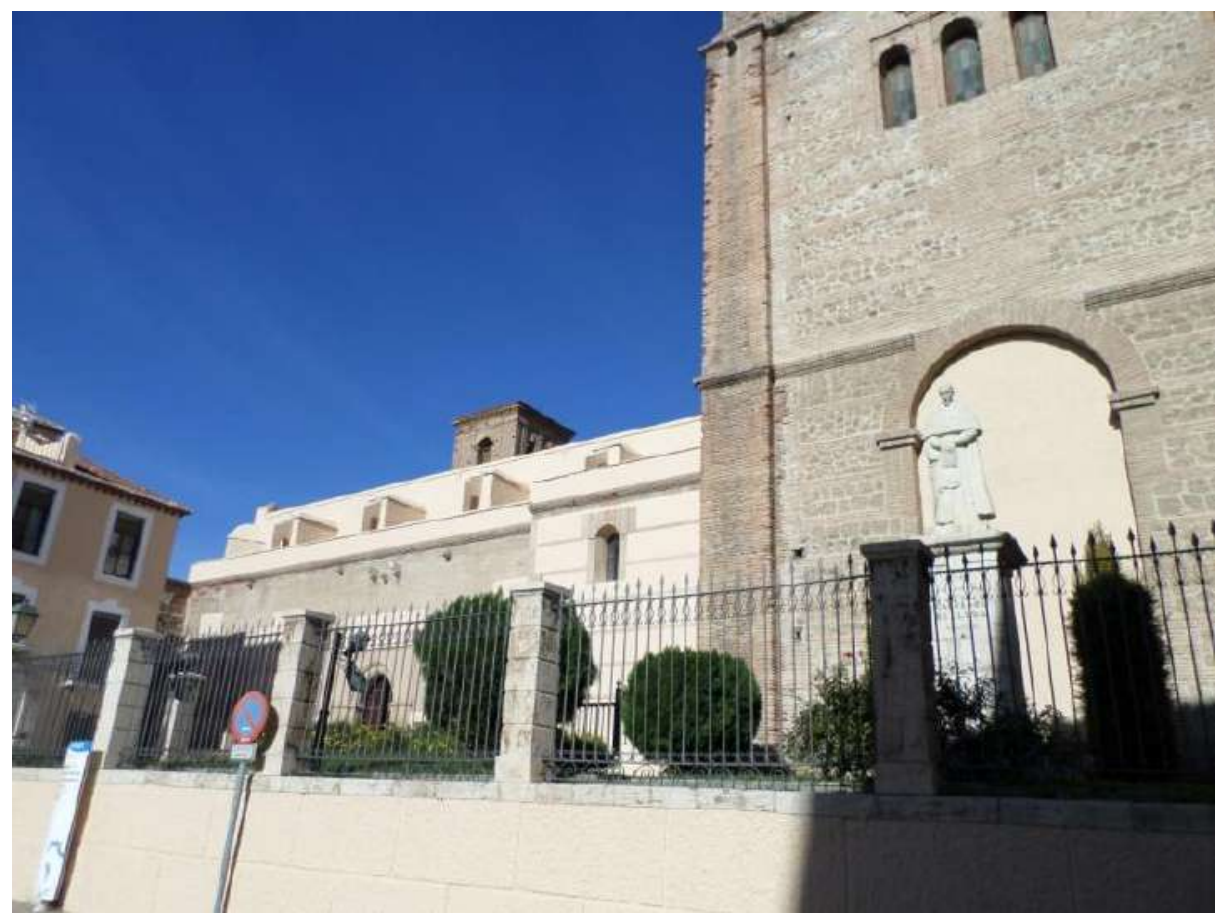

1) Iglesia Mayor Parroquial de la Encarnación.

La planta de la iglesia es de cruz latina, de tres naves, siendo las laterales en realidad capillas comunicadas entre sí, separadas por cinco arcos. Los tres primeros arcos son apuntados y los dos siguientes son de medio punto. ${ }^{104}$ Los arcos apuntados están apoyados directamente sobre los pilares cuadrados y los arcos de medio punto sobre una cornisa antes de pasar a los pilares. La nave central es más elevada y ancha que las laterales y estas naves laterales tienen capillas entre los contrafuertes. La iglesia tiene un crucero que se construyó en el s. XVII por el maestro Martín de Soto ${ }^{105}$, se accede a él desde las naves de la iglesia por medio de un arco toral de medio punto y a través de él se da paso a la capilla mayor no diferencia ${ }^{106}$, a la sacristía y a diferentes capillas.

103 VV.AA. El Patrimonio artístico de Motril. Motril: Ayuntamiento de Motril. Área de Cultura y Patrimonio, 2003., págs. 49-49.

${ }^{104}$ Esto es fruto de las diferentes ampliaciones que la iglesia ha sufrido en el tiempo y por ello de la variedad estilística que tiene.

105 VV.AA. El Patrimonio artístico... Op. cit., pág. 53.

${ }^{106}$ Este tipo de planta de cruz latina, con nave con capillas laterales (que en este caso parecen naves laterales), con crucero, aunque no tenga capilla mayor diferenciada, puede responder en cierta medida al esquema de tipología de planta de iglesia mudéjar de Granada descrito por Don Rafael López Guzmán en:

- $\quad$ LÓPEZ GUZMÁN, Rafael. Arquitectura...Op. cit., pág. 399. 


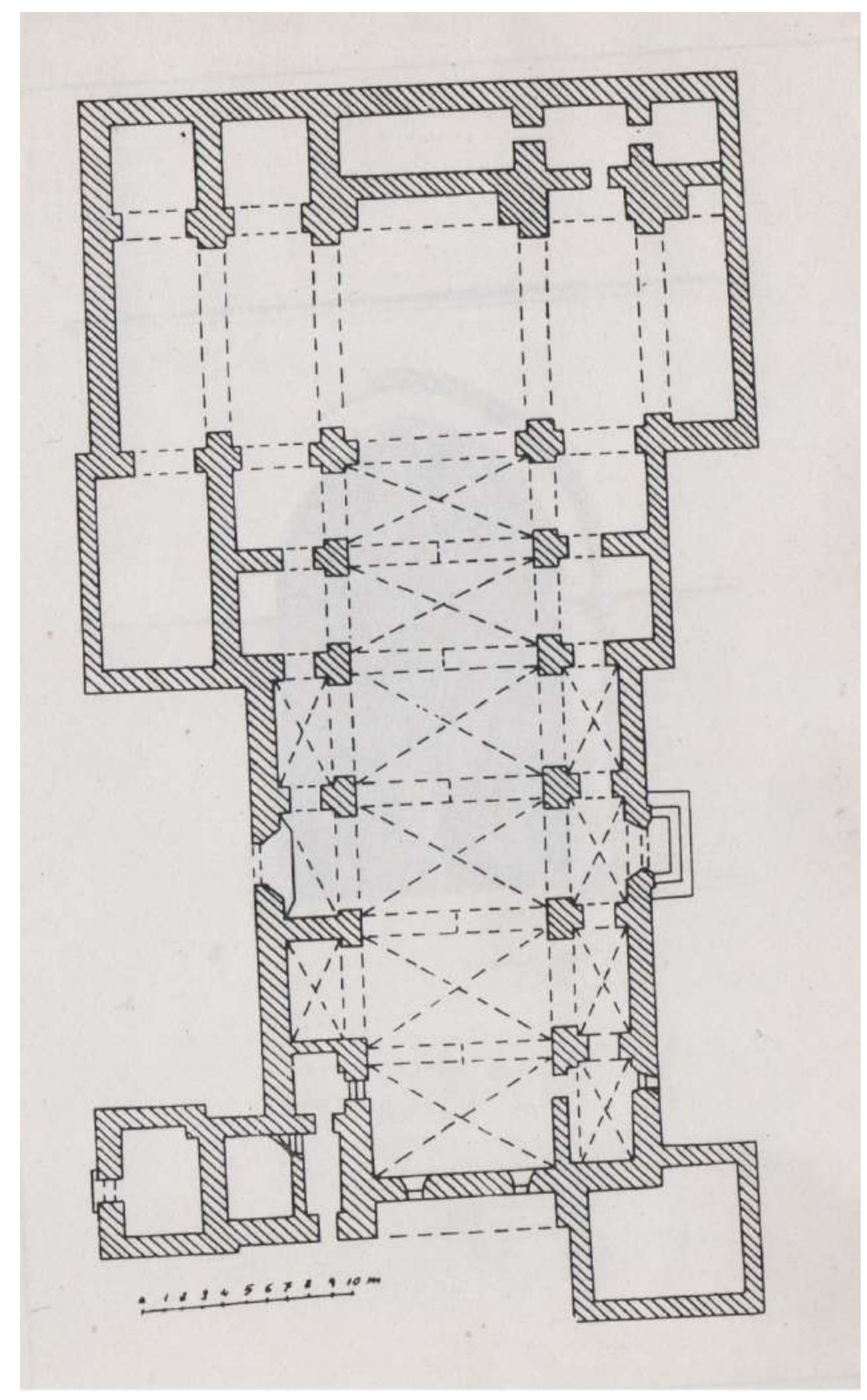

2) Plano de la iglesia en el s. XX. ${ }^{107}$

${ }^{107}$ DOMÍNGUEZ GARCÍA, Manuel. La Iglesia Mayor de Motril: cinco siglos de evolución histórica de su fábrica. Motril: El Autor, 1983. 


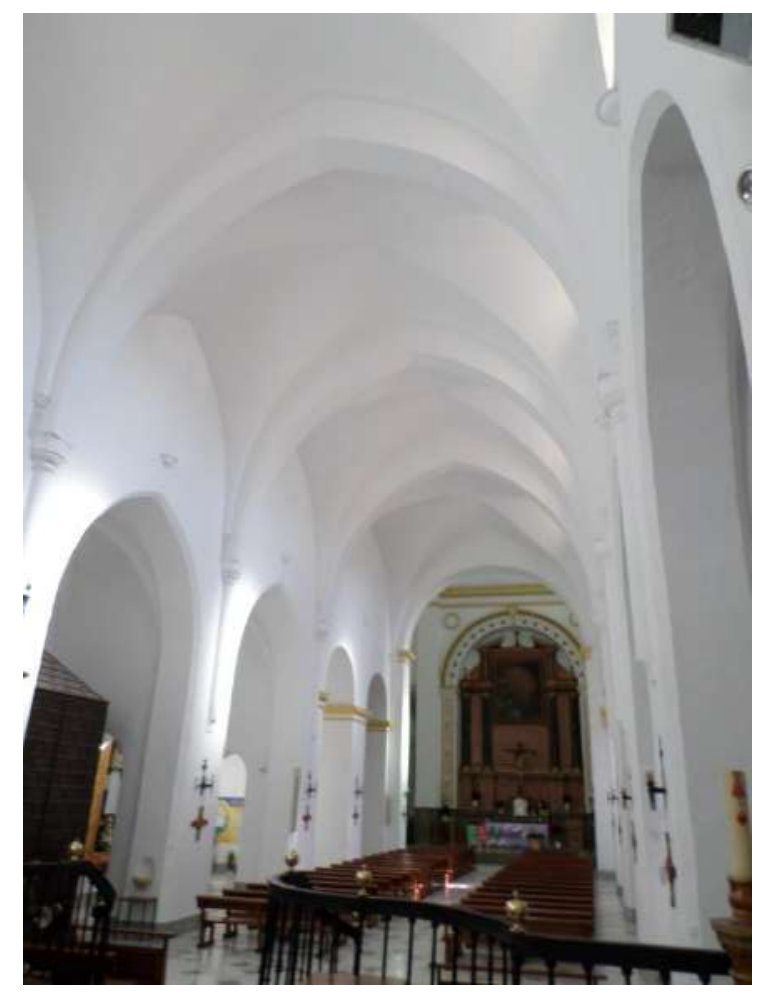

3) Nave central de la iglesia.

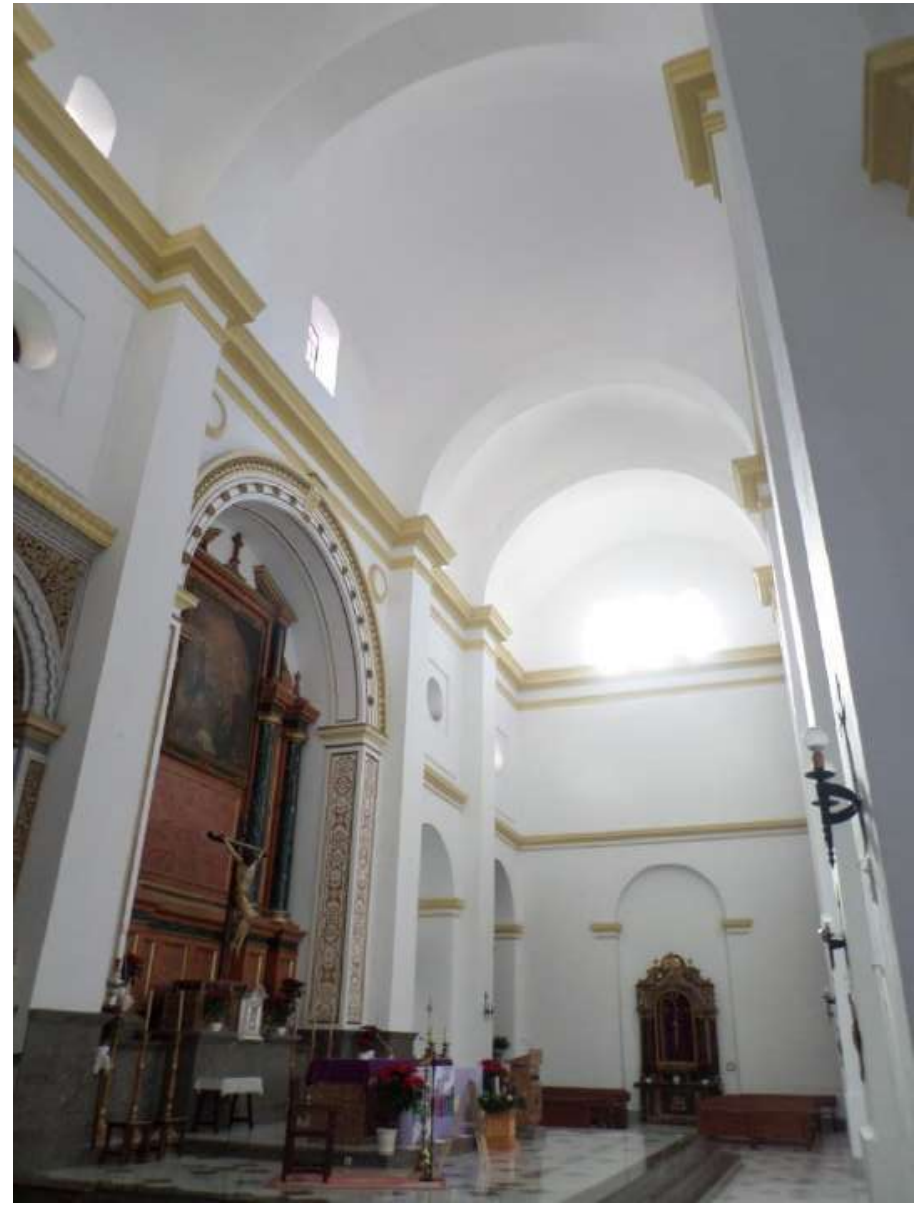

4) Crucero. 


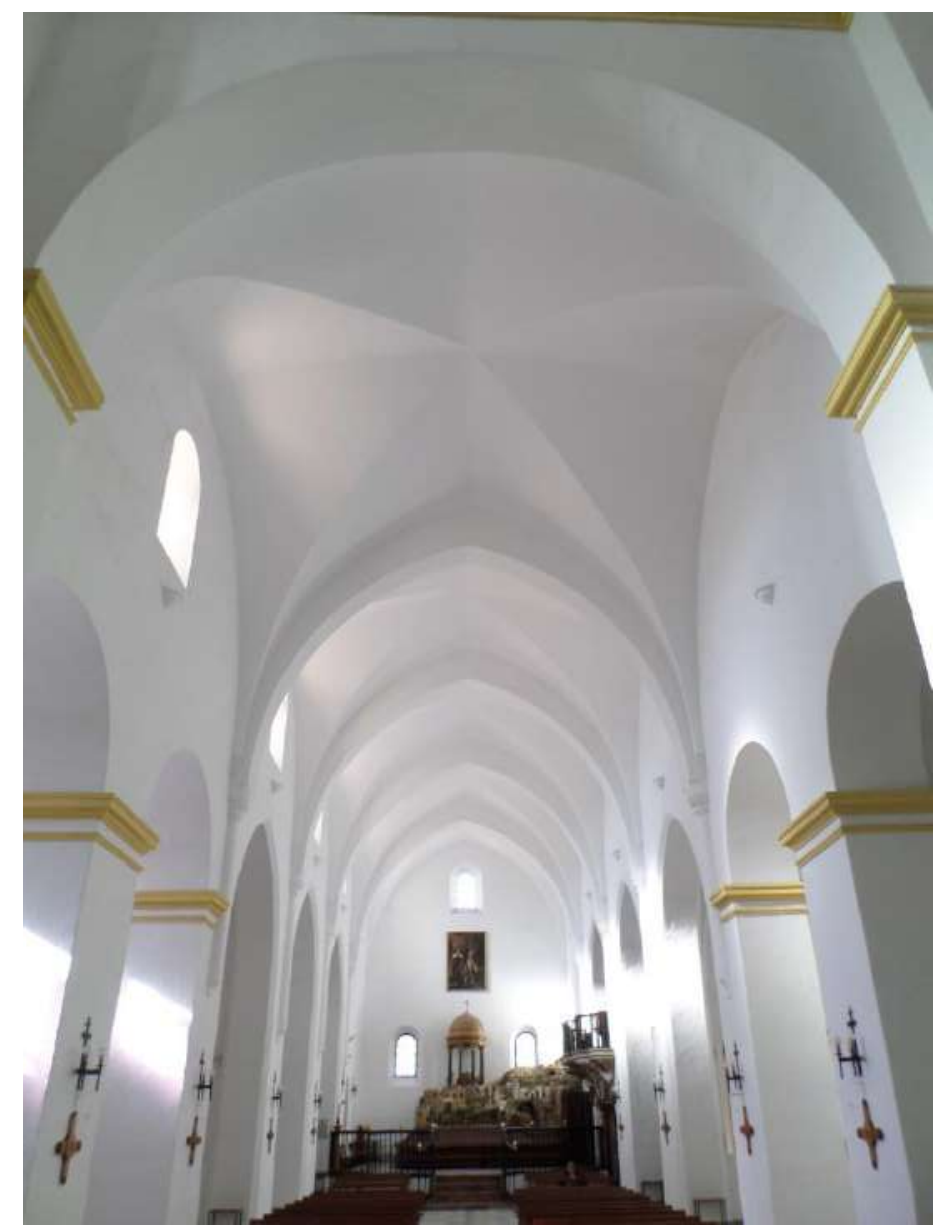

5) Vista del arco toral y de la nave central desde el altar mayor.

En el exterior de la iglesia podemos percibir la configuración interna del templo de las tres naves, viéndose claramente que la central es más alta y ancha que las laterales, además de vislumbrarse los contrafuertes de las propias naves laterales. Este templo actualmente tiene dos portadas de acceso, la sur y la norte, pero primitivamente tenía la oeste y la sur, siendo la oeste la principal. ${ }^{108}$ Aquí analizaremos las tres, la norte, sur y oeste. Así, la portada oeste o primitiva ${ }^{109}$ constaba de un arco apuntado enmarcado por un alfiz en origen decorado por azulejos ${ }^{110}$, rodeado por dos vanos de arcos de medio punto que iluminan el interior del actual coro, situándose otro vano en la parte superior de la portada. La puerta sur consta de un doble arco apuntado de ladrillo rodeado de un alfiz actualmente de ladrillo también pero que primitivamente era de azulejos. ${ }^{111}$ Junto con esta puerta hay en el muro dos vanos adintelados con arcos de

\footnotetext{
108 VV.AA. El Patrimonio artístico... Op. cit., pág. 49.

109 Actualmente cerrada.

${ }^{110}$ VV.AA. El Patrimonio artístico... Op. cit., pág. 49.

${ }^{111}$ Ibídem., pág. 50
} 
descarga que iluminan la nave lateral derecha. La portada norte consta de un doble arco de medio punto de ladrillo y rodeado de un alfiz de ladrillo también. ${ }^{112}$ Un vano con arco de medio punto se sitúa al lado de esta puerta. El crucero presenta en sus lados mayores contrafuertes, vanos con arcos de descarga con alfiz y óculos, y en sus lados menores, tres arcos de medio punto enmarcados en un alfiz. El arco central de estos tres arcos está coronado por un frontón triangular. Un arco de medio punto sostenido por pilares aparece en estos lados menores. ${ }^{113}$

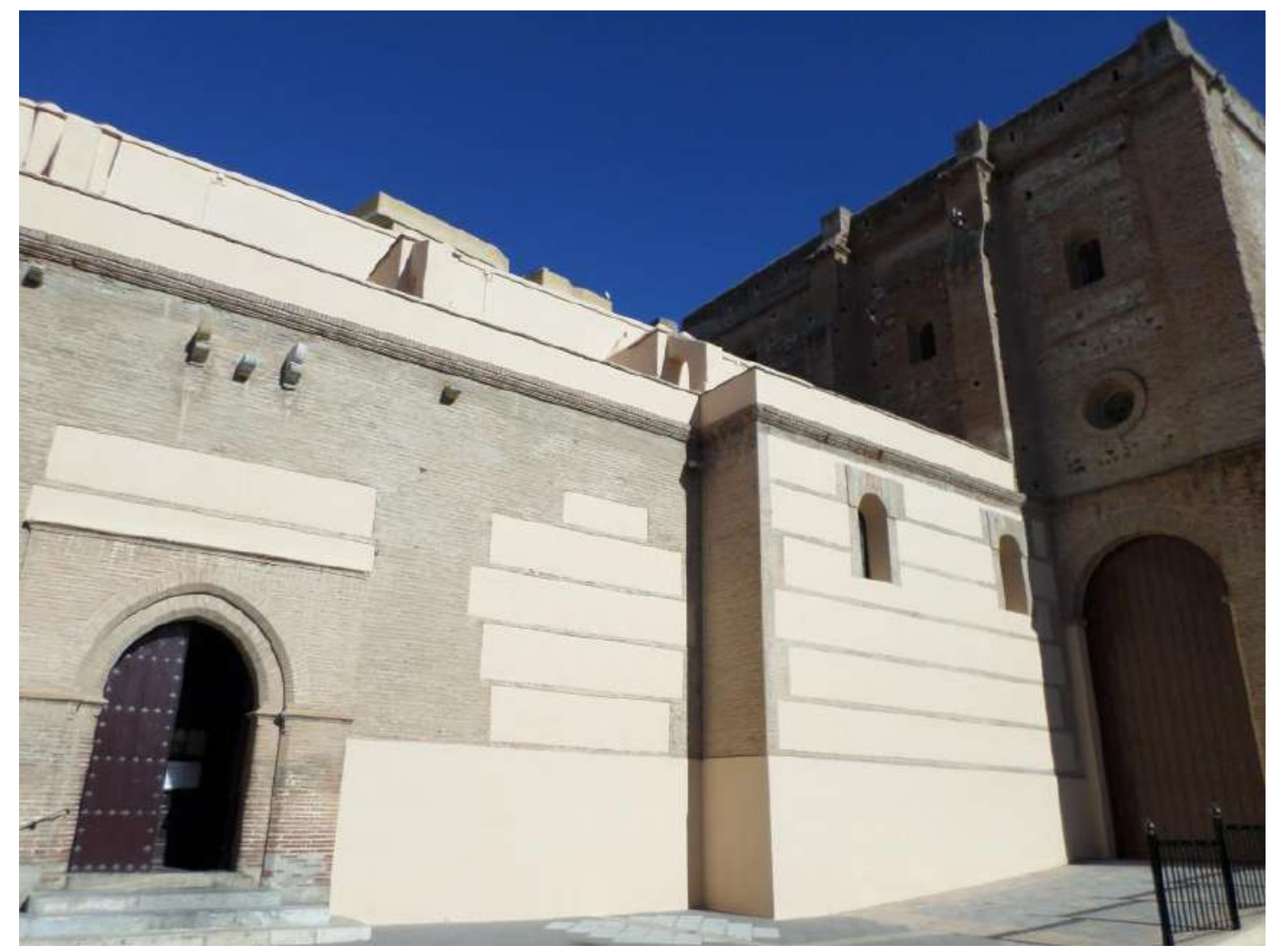

6) Portada sur. ${ }^{114}$

112 No sabemos si cuando se construyó la puerta, el alfiz tendría azulejos.

${ }^{113}$ Estos arcos se corresponden con las entradas a las antiguas capillas de Nuestra Señora de los Dolores y Nuestro Padre Jesús Nazarenos, según el propio testimonio de los vecinos, y que desaparecieron tras la explosión de un polvorín después de la Guerra Civil española.

${ }^{114}$ En esta foto podemos observar la configuración de tres naves de la iglesia, junto con la puerta sur y parte del crucero. 


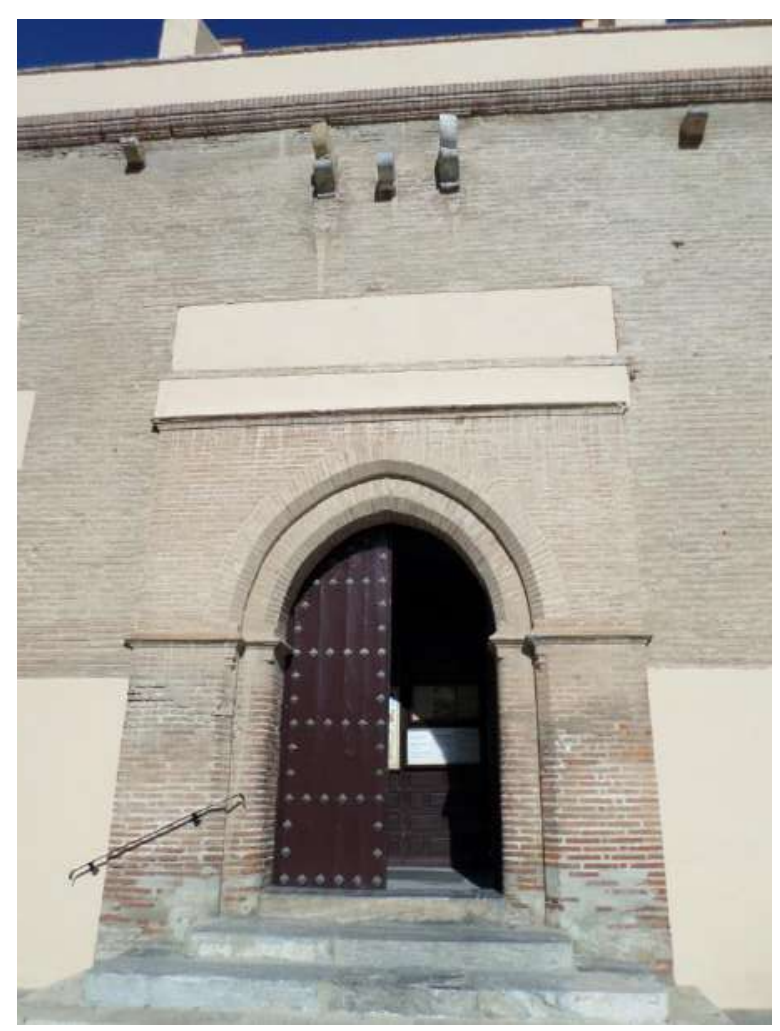

7) Puerta sur.

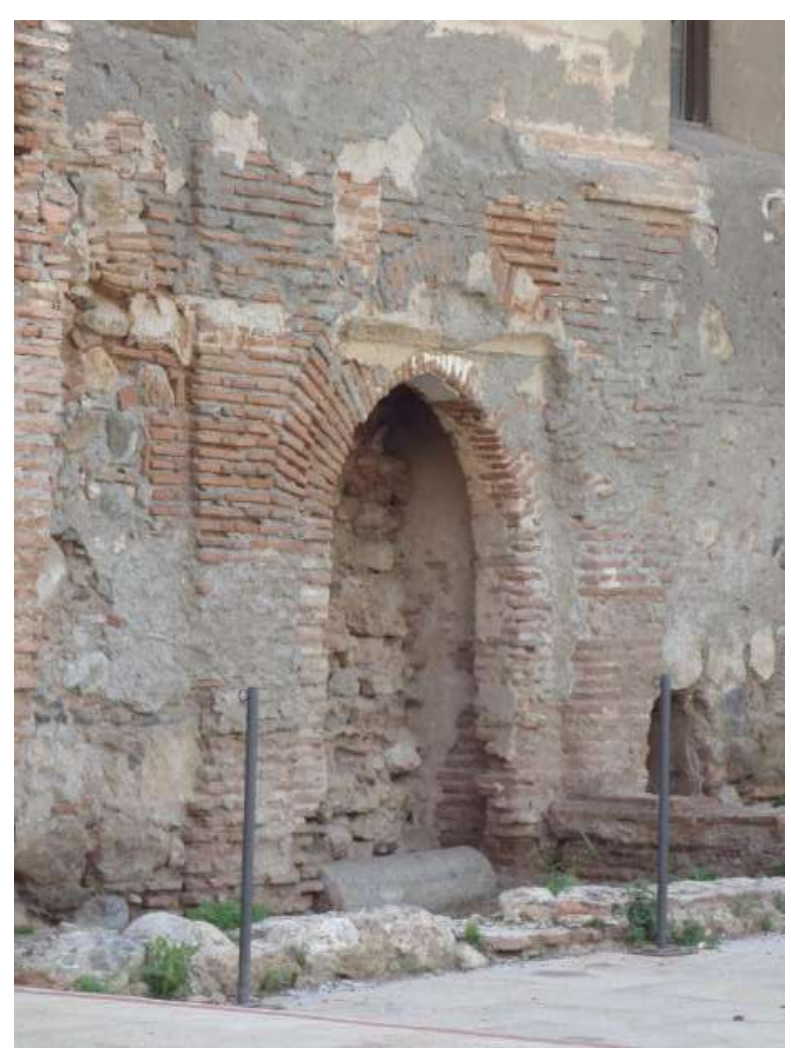

8) Puerta oeste, hoy cerrada. 


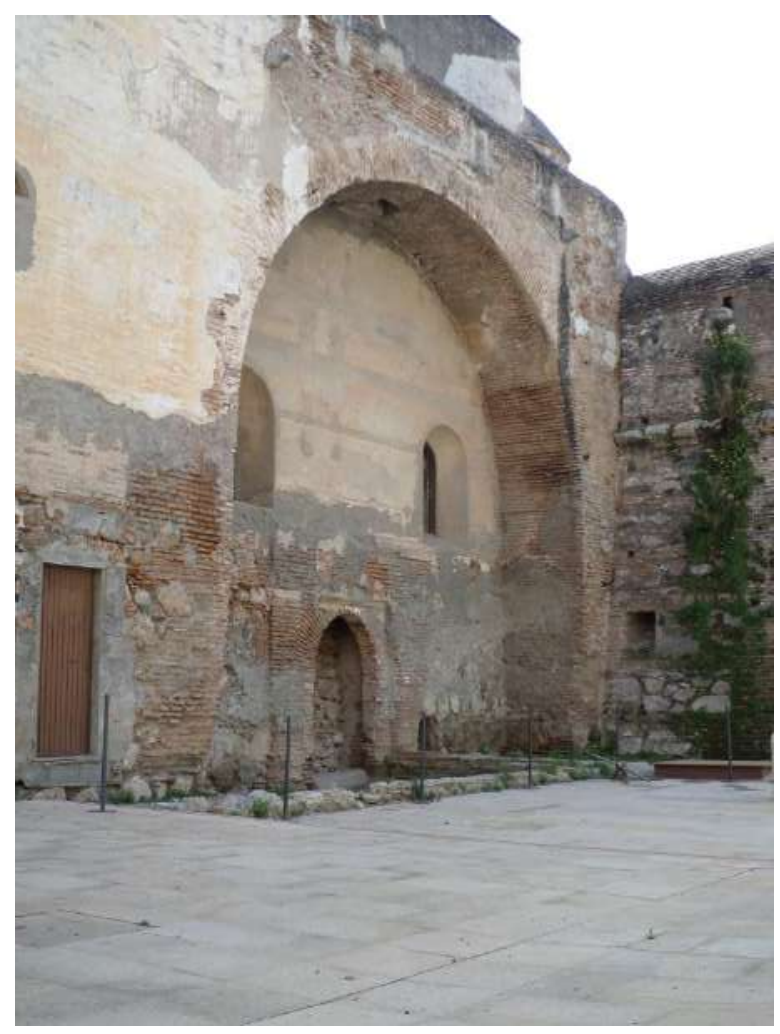

9) Fachada de la puerta oeste.

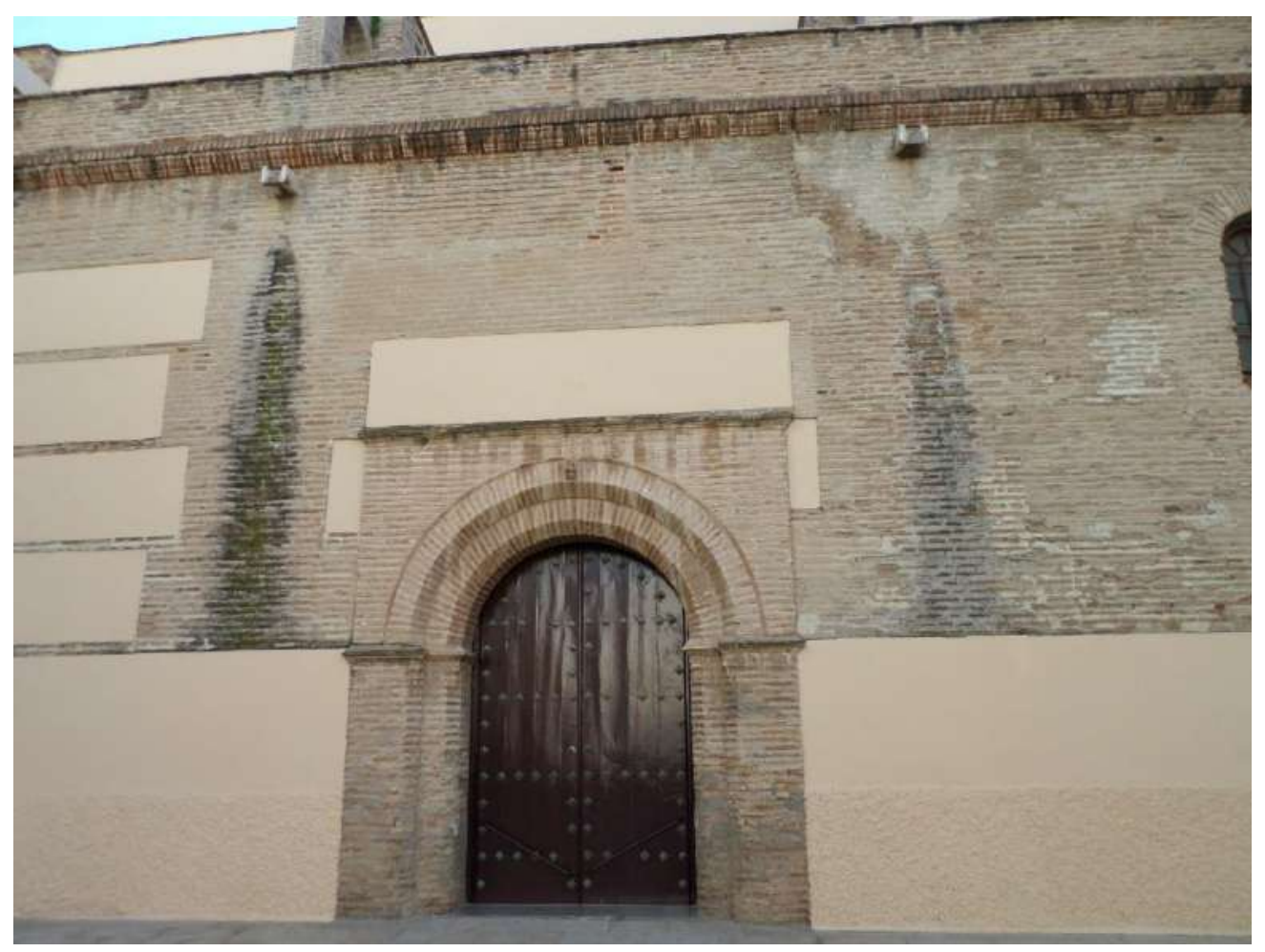

10) Puerta norte. 


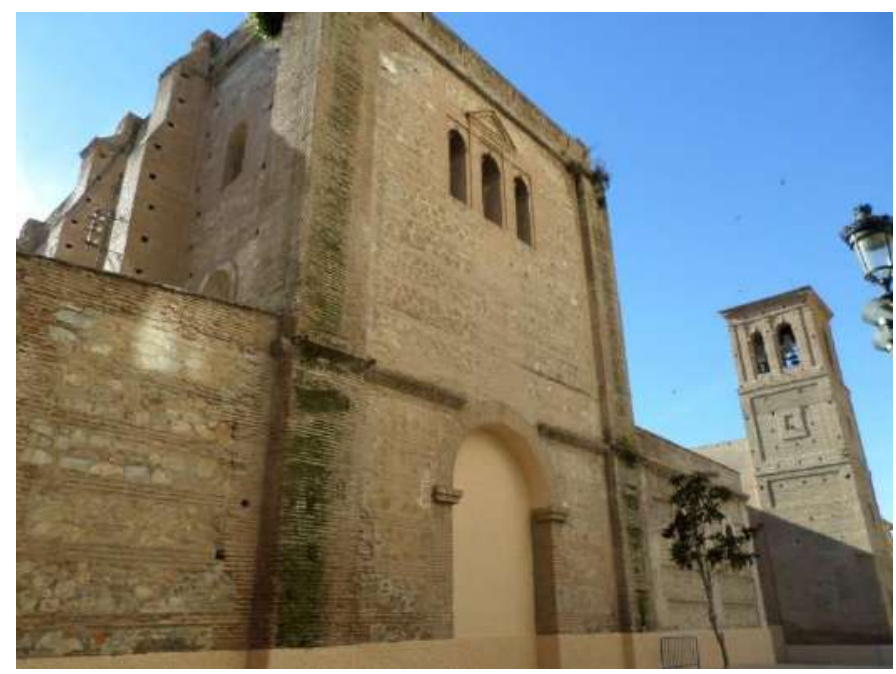

11) Lado menor del crucero.

En el interior, hemos de decir que los muros de la iglesia son de cerramiento, de descarga de los elementos superiores, son gruesos y dan gran sensación de solidez. La nave central está cubierta por bóvedas de crucería con arcos fajones apuntados, que descargan su peso en los pilares laterales por medio de columnas dóricas. Las naves laterales hemos de decir que hasta donde están situados los tres arcos apuntados están cubiertas por bóvedas de crucerías, y donde están los arcos de medio punto están cubiertas por bóvedas de cañón. El crucero presenta bóveda de cañón con arcos fajones de medio punto.

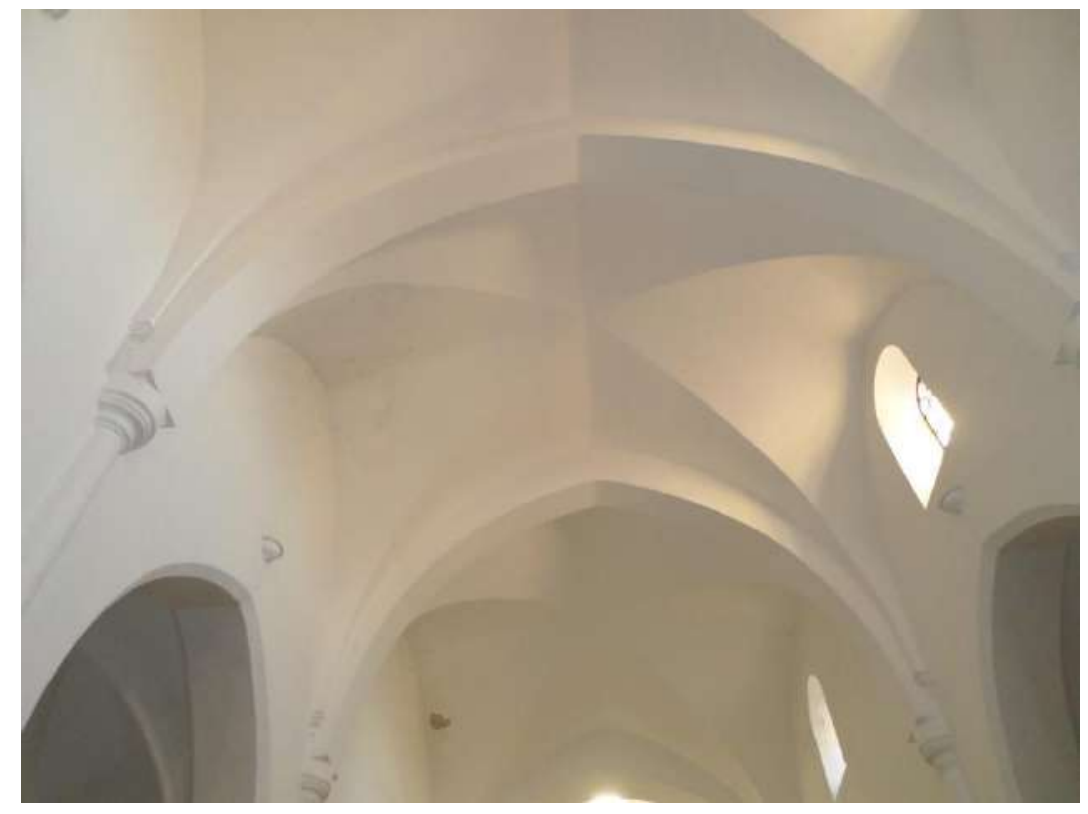

12) Bóvedas de crucería de la nave central. 


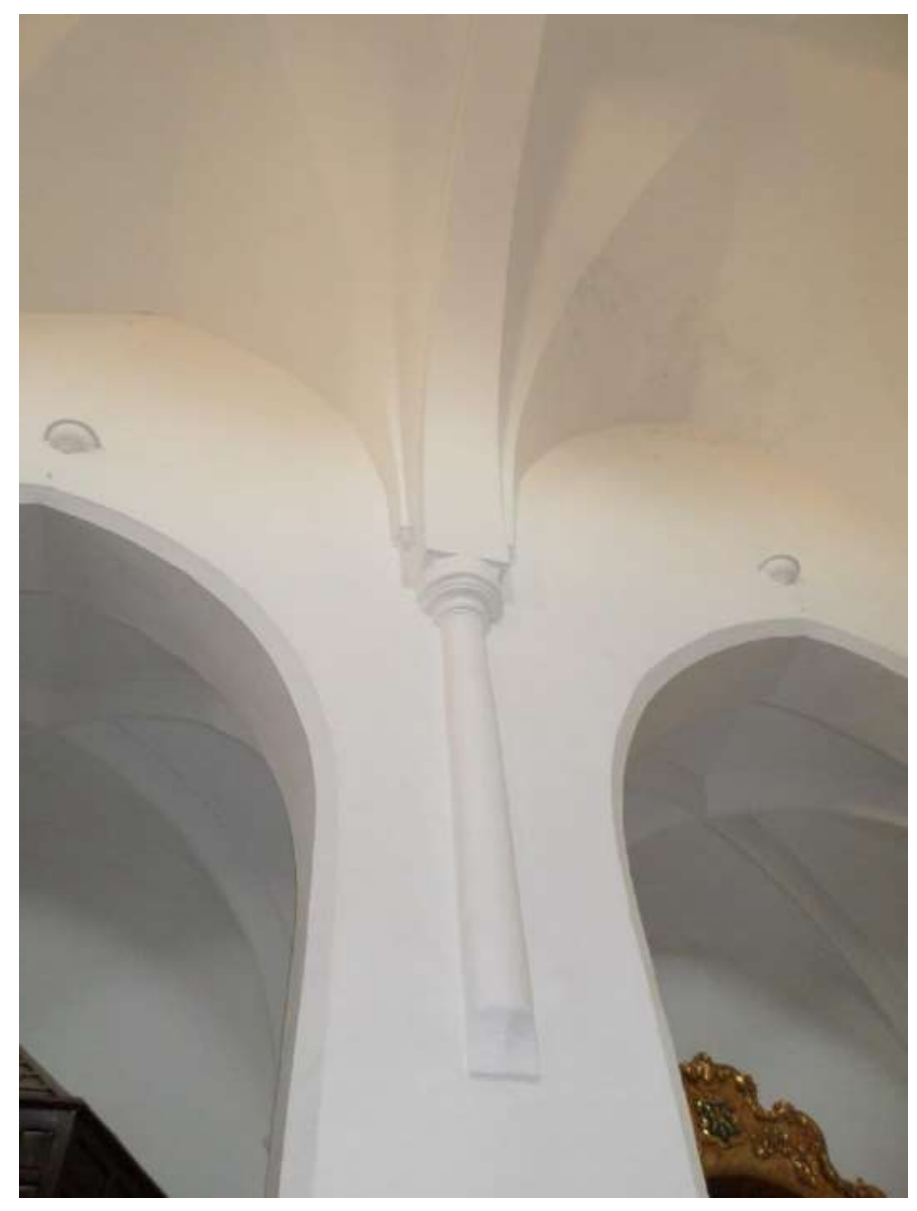

13) Columnas de descarga de las bóvedas de crucería.

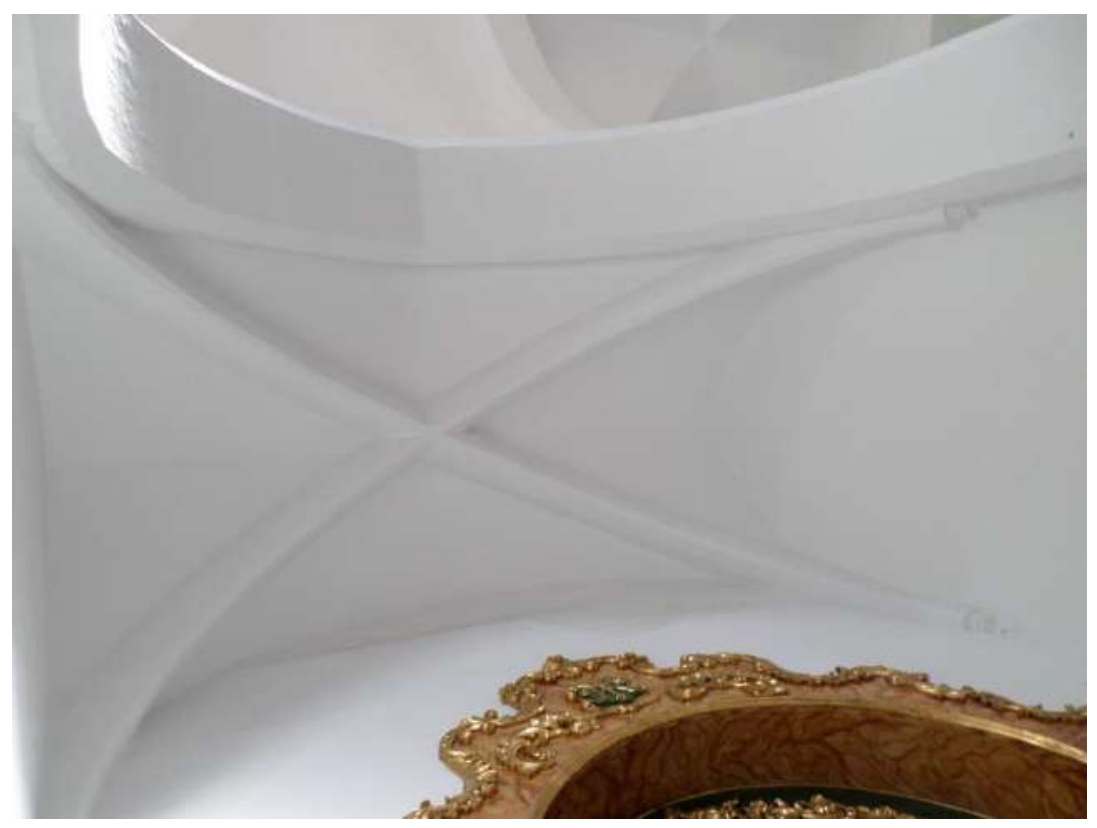

14) Bóvedas de crucería en la nave lateral izquierda. 


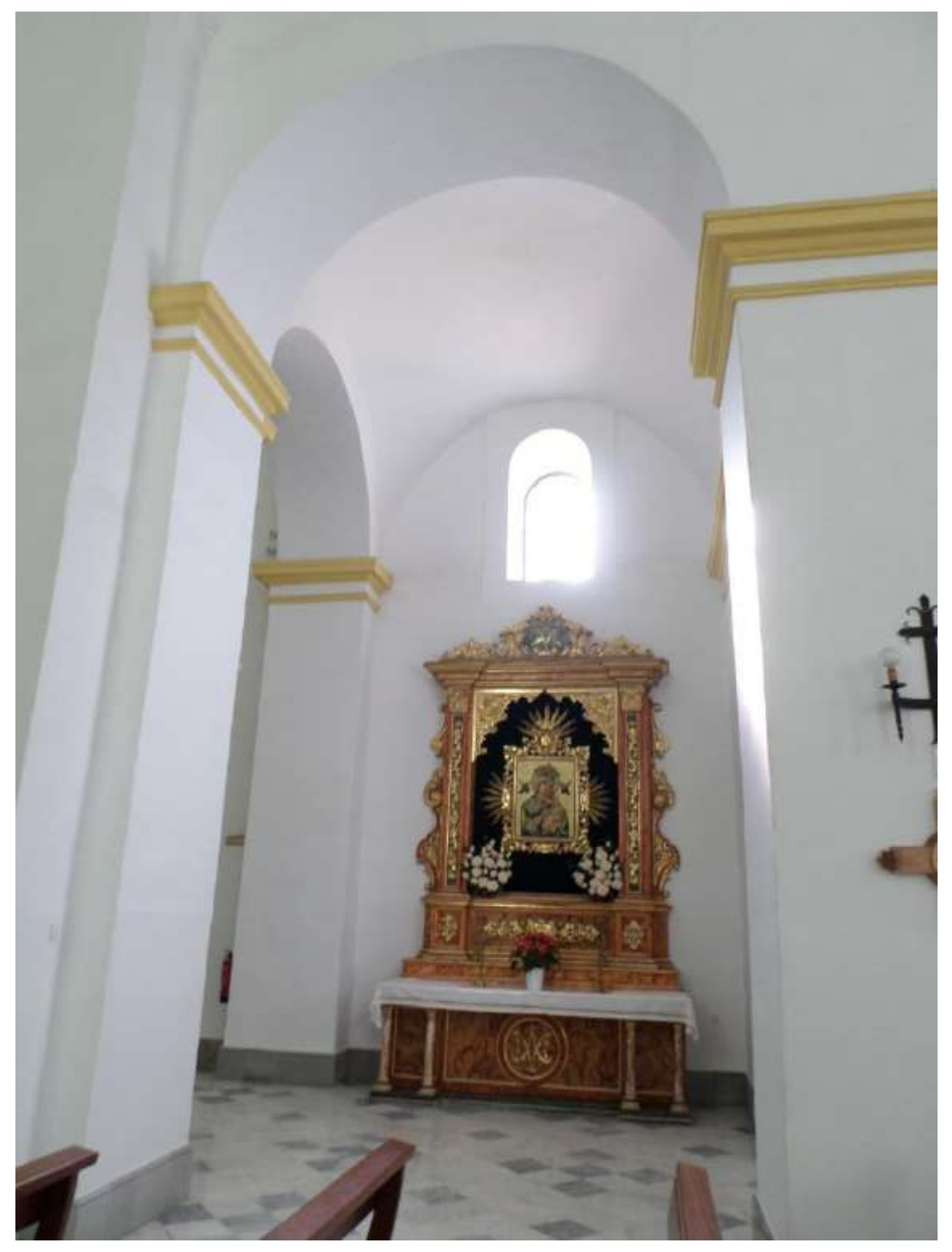

15) Bóveda de cañón en la nave lateral derecha.

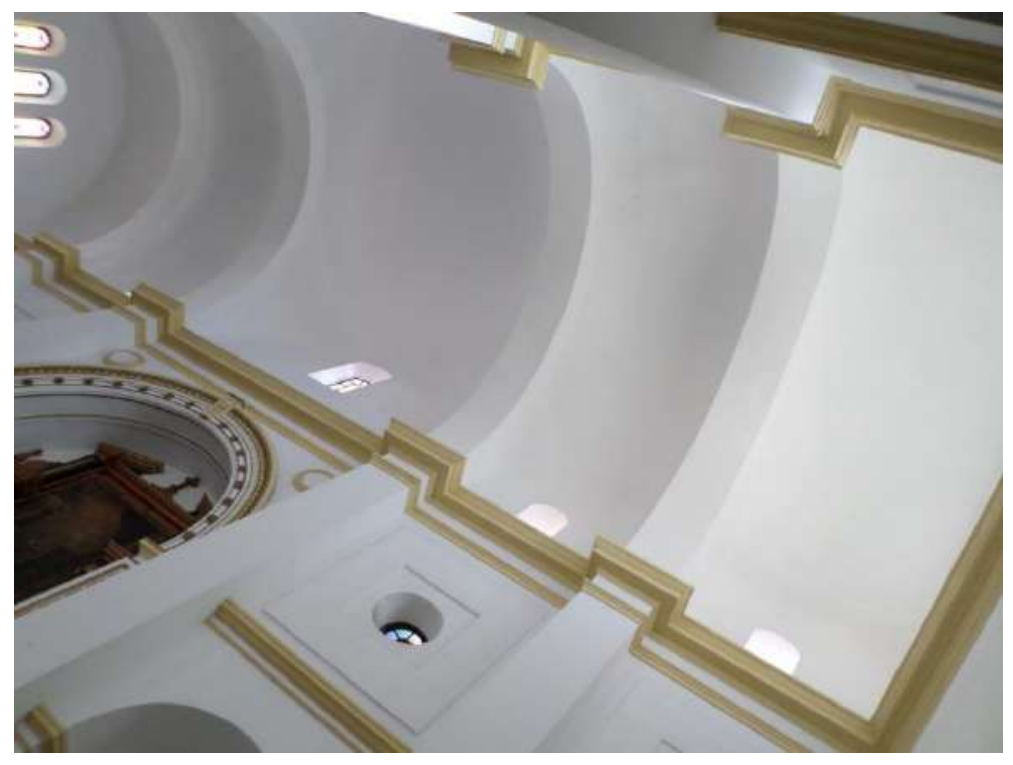

16) Bóveda de cañón del crucero. 
Por último, pasamos a comentar la torre que está situada en el lado NO de la iglesia y está construida en ladrillo. Esta torre tiene cuatro cuerpos separados por cornisas. El lado norte de la torre presenta en su primer cuerpo la entrada y un vano adintelado de ladrillo. En el segundo cuerpo y tercer cuerpo un vano adintelado también de ladrillo, al igual que el tercer cuerpo de la cara este. Las campanas se sitúan en el cuarto y último cuerpo, y se posicionan, por los lados norte y sur, en un arco de medio punto rodeado por columnas, y por los lados este y oeste, en dos arcos de medio punto enmarcados por columnas. La torre está coronada por una cornisa.

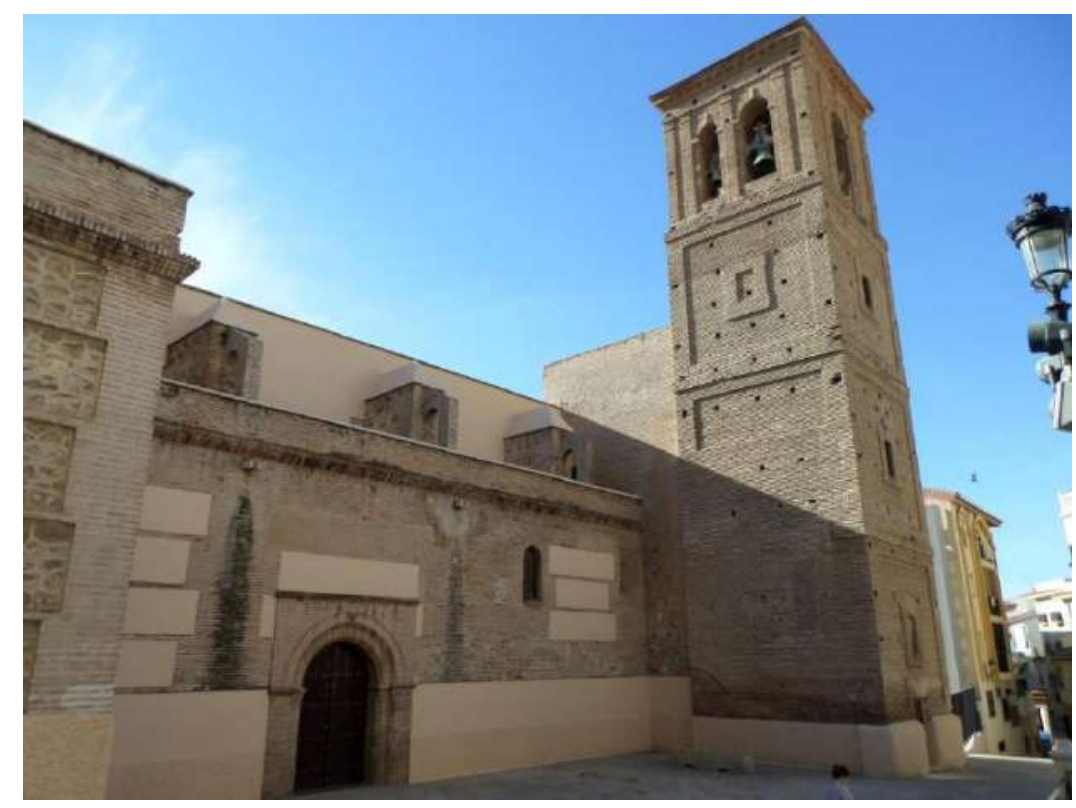

17) Torre de la iglesia.

De la iglesia que hemos descrito, la parte mudéjar sería todo el exterior con sus cintas de ladrillo y yeso y cajones de mampostería que junto con la gran torre de ladrillo son mudéjares. Las portadas sur, norte y oeste con sus destacados alfiles también son de este estilo, y los alfiles de los arcos de todos los vanos.

\subsection{Convento e Iglesia de los Franciscanos Mínimos de la Victoria de Motril.}

Siendo unos de los centros religiosos más concurridos por los motrileños desde su fundación en el s. XVI hasta hoy, el Convento de los Mínimos de San Francisco de Paula y actual Convento de los PP. Agustinos Recoletos ha sufrido numerosas transformaciones arquitectónicas y artísticas que han hecho desaparecer todo el esplendor de los siglos precedentes y tan solo ahora conocemos por documentos y escasas imágenes. 


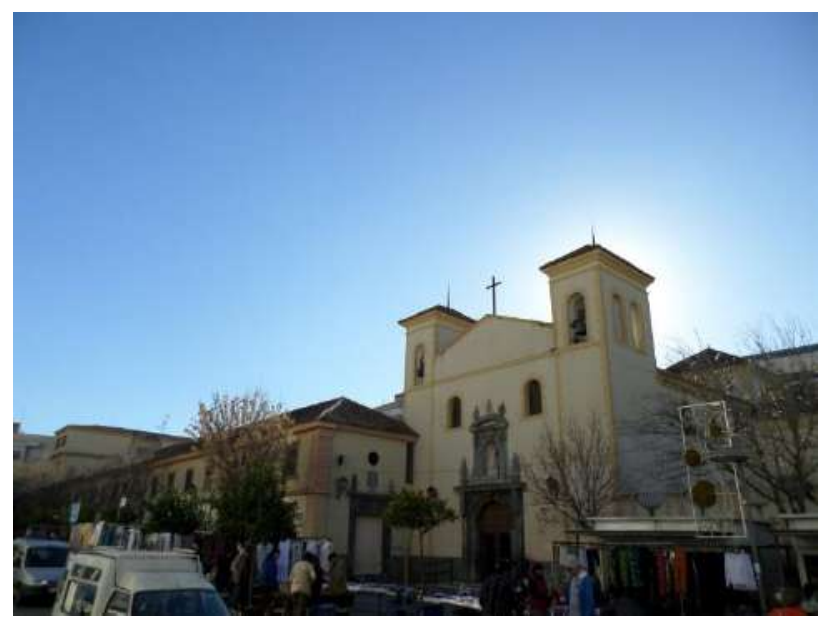

1) Actual Iglesia y Colegio de los Agustinos Recoletos.

\section{Historia.}

Una vez, establecido en Motril, esta orden de Franciscanos Mínimos, tras numerosas concesiones, realizaron la construcción de su convento e iglesia en el sur de la villa, cerca de los Baños Árabes (hoy desaparecidos), y bajo la advocación de Nuestra Señora de la Victoria, nombre que ha llegado hasta nuestros días.

\section{Convento.}

Sobre el convento, desaparecido hoy, ya que fue destruido en la Guerra Civil y demolido posteriormente por la Orden Agustina para la construcción del Colegio de San Agustín, hemos de decir que nos remite a un esplendor pasado, donde las influencias del arte mudéjar se dejaron sentir enormemente. ${ }^{115}$

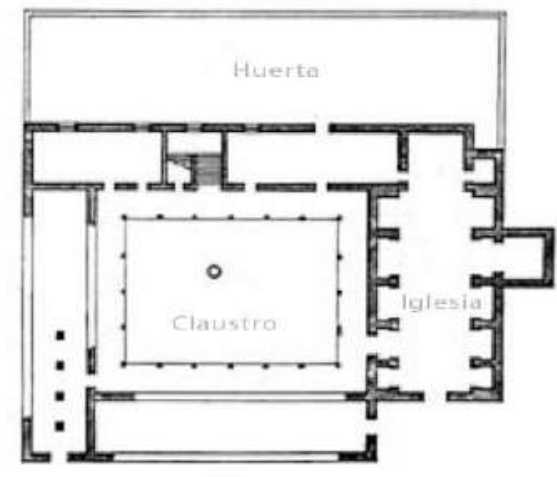

2) Plano Primitivo del Convento e Iglesia. ${ }^{116}$

115 VV.AA. El Patrimonio artístico ... Op. cit., págs. 79-80.

${ }^{116}$ www.rinconesdegranada.com 
El edificio conventual tenía una forma rectangular, y se configuraba entre la vida monástica propia de la orden y la vida apostólica que llevaban a cabo los monjes en la villa, y desde el punto de vista arquitectónico y artístico, según nos cuenta el profesor Gallego Burín, es heredero de la fuerte tradición mudéjar. ${ }^{117}$

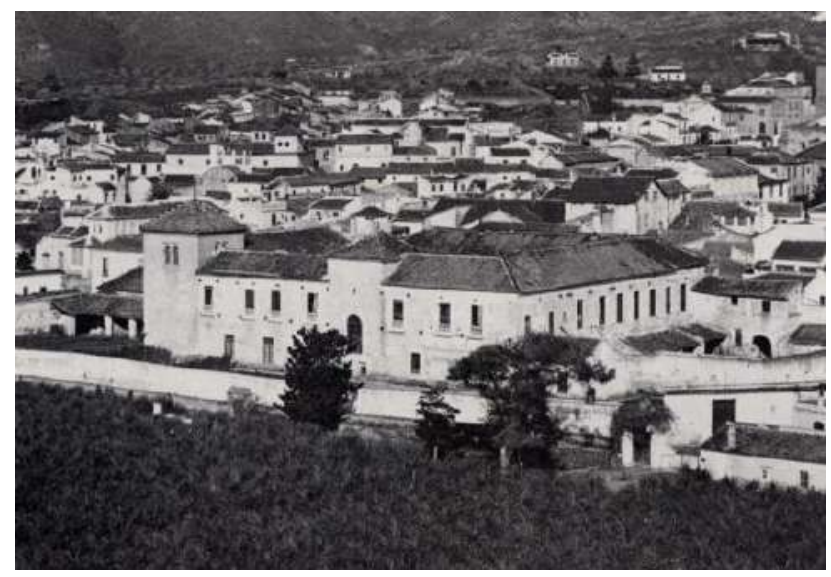

3) Vista del Convento de los Mínimos (Agustinos), principios del s. XX. ${ }^{118}$

Dispuesto sobre dos plantas, en torno a un patio central, el mudéjar no solo se deja sentir en esta configuración estructural, a partir de la cual se distribuyen todas las dependencias (biblioteca, refectorio, sala capitular, celdas...) $)^{119}$ sino también en las armaduras tanto del claustro bajo como del alto. La armadura del claustro bajo tenía forma de par hilera, mientras que la del alto era un alfarje que descansaba directamente en el paramento.

También, en la escalera monumental por la cual se accedía a dicho claustro alto, que se ubicaba en el testero sur, con dos tramos, existía una solería y contra solería que contenía un aderezo de azulejos con decoración y configuración mudéjar. $^{120}$

117 GALLEGO BURÍN, A. Informe sobre las pérdidas y daños sufridos por el Tesoro Artístico de Granada de 1931 a 1936 e indicación de las obras salvadas de la destrucción marxista, redactado por el Seminario de Arte de la Universidad de Granada y el Servicio Artístico de Vanguardia. Granada: Imprenta $\mathrm{H}^{\circ}$. de Paulino Ventura, 1937., pág. 109.

$118 \mathrm{http}$ ///www.cofradiasaludyconsuelo.com/fotos-antiguas-iglesia-de-la-victoria-pp-agustinos$\underline{\text { motril. }}$

${ }^{119}$ VV.AA. El Patrimonio artístico... Op. cit., págs. 80-81.

${ }^{120}$ LÓPEZ FERNÁNDEZ, Domingo A ${ }^{\circ}$. "Los Mínimos de San Francisco de Paula. Precedentes y fundación del Convento de la Victoria en la Villa de Motril.” En: SÁNCHEZ RAMOS, Valeriano (Coord.) Los Mínimos en Andalucía. IV Centenario de la fundación del Convento de Nuestra Señora de la Victoria de Vera (Almería). Almería: Instituto de Estudios Almerienses, Ayuntamiento de Vera y Orden Mínima. 2006. págs. 187-237., pág., 225. 


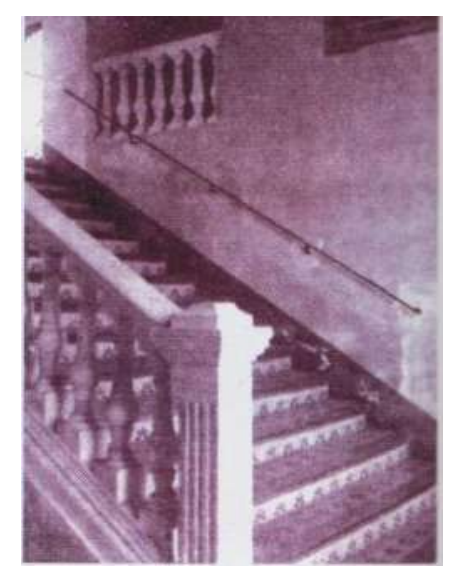

4) Escalera monumental. ${ }^{121}$

Pero como hemos comentado al principio, la historia y la voluntad del Ser Humano ha querido que este convento desapareciera, y ahora tan solo queda en el recuerdo y en la memoria de unos pocos.

Del Convento que hemos descrito y que ha desaparecido por completo, la parte mudéjar fue la estructura convento en torno a un patio central, junto con las destacadas armaduras del claustro bajo y del claustro alto, y la gran escalera monumental que daba acceso al claustro alto.

\section{$\underline{\text { Iglesia de la Victoria. }^{122}}$}

Iglesia del s. XVII de clara simbiosis entre el mudéjar y las corrientes contrarreformistas como bien afirma el profesor José Manuel Gómez Moreno en su libro "La Arquitectura religiosa granadina en la crisis del Renacimiento (1560/1650). ${ }^{123}$

El principal estilo de esta iglesia es el mudéjar, aunque actualmente apenas se percibe debido a su fuerte transformación, algo que conocemos gracias a consulta de documentos ${ }^{124}$ y al propio estudio de la iglesia. Así, este templo fue construido en piedra, ladrillo, yeso y madera, pero hoy ninguno de ellos se ve, tan solo el yeso del interior; de manera que tanto las cintas de ladrillo y yeso junto con los cajones de mampostería del exterior fueron revocados a finales del s. XIX como

${ }^{121}$ VV.AA. El Patrimonio artístico... Op. cit., pág. 80.

${ }^{122}$ Se construyó anexa al convento, en el lado derecho.

${ }^{123}$ GÓMEZ-MORENO CALERA, J.M. La arquitectura religiosa.... Op. cit., pág., 363.

${ }^{124}$ LÓPEZ FERNÁNDEZ, Domingo A ${ }^{\circ}$. "Los Mínimos de San Francisco de Paula. Precedentes .... Op. cit., págs., 227-237. 
podemos percibir en la documentación gráfica de la época y las armaduras desaparecieron tras los destrozos acaecidos en la Guerra Civil española. ${ }^{125}$

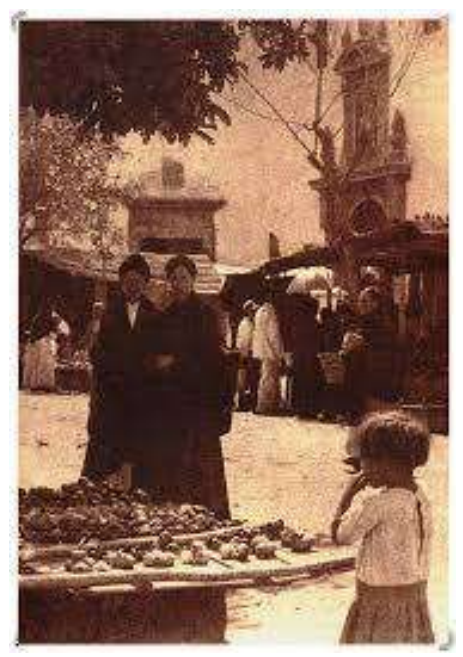

5) Imagen de finales del s.XIX de la Iglesia de la Victoria. ${ }^{126}$

La iglesia tiene nave única rectangular con capillas entre contrafuertes a las que se accede por medio de cuatro arcos de medio punto sostenidos por pilares cuadrados contienen, en el lugar donde descansan los arcos, un capitel. La nave central, que presenta un coro alto a los pies sostenido por un arco carpanel, es más elevada con respecto a las capillas laterales, y por ella se accede a la capilla mayor por medio de un arco toral de medio punto ${ }^{127}$ muy decorado con formas florales y escudos nobiliarios y con una clave alusiva a la Eucaristía y sostenido por columnas. La capilla mayor está elevada y por ella se da paso a la sacristía y dependencias del actual convento. También esta capilla presenta unas cartelas primitivas donde se hace referencia a los fundadores del primitivo convento e iglesia ${ }^{128}$ además de presentar decoración barroca. A través del lateral derecho de la nave de la iglesia se accede a la Capilla del Sagrado Corazón de Jesús del s. XVIII.

125 Ibídem., pág. 233.

${ }^{126}$ http://www.cofradiasaludyconsuelo.com/fotos-antiguas-iglesia-de-la-victoria-pp-agustinos-

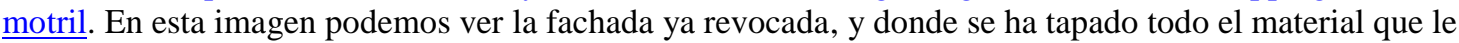
daba la configuración mudéjar a la Iglesia.

${ }^{127}$ Este tipo de planta de nave única rectangular cubierta por una armadura, como veremos más adelante, con capillas laterales entre contrafuertes y capilla mayor separada por un arco toral responde a la tipología de planta de iglesias mudéjares de Granada según el estudio realizado por Don Rafael López Guzmán y Don Ignacio Henares Cuéllar en:

- $\quad$ HENARES CUÉLLAR, Ignacio; LÓPEZ GUZMAN, Rafael. Arquitectura Mudéjar.... Op. cit.

${ }^{128}$ LÓPEZ FERNÁNDEZ, Domingo A. "Los Mínimos de San Francisco de Paula. Precedentes .... Op. cit., págs., 187-237. 


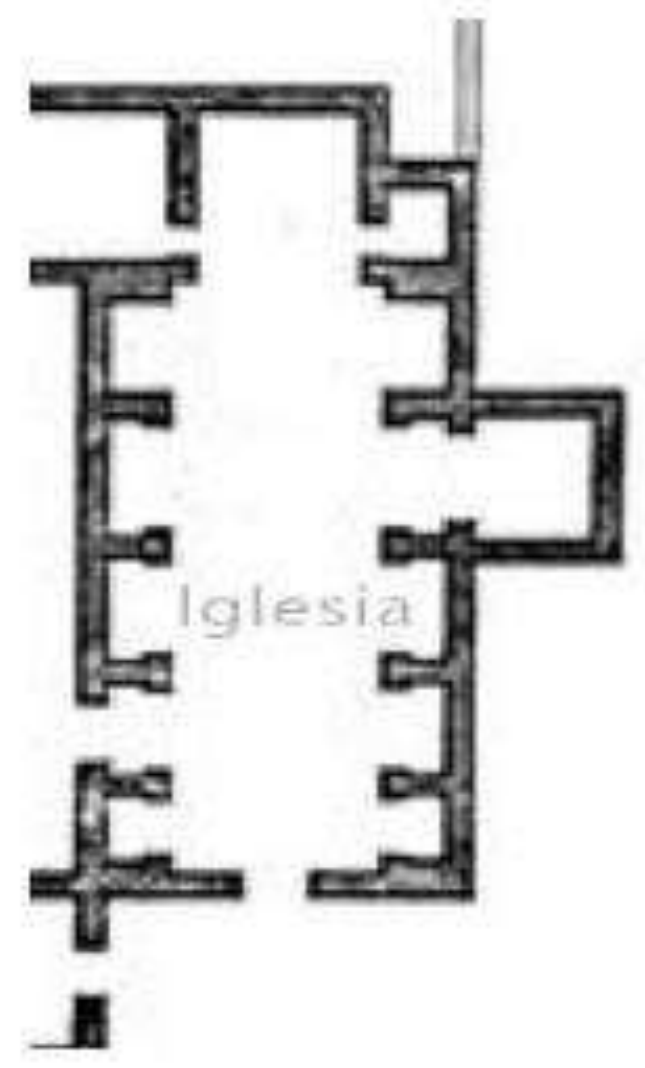

6) Planta de la Iglesia. ${ }^{129}$

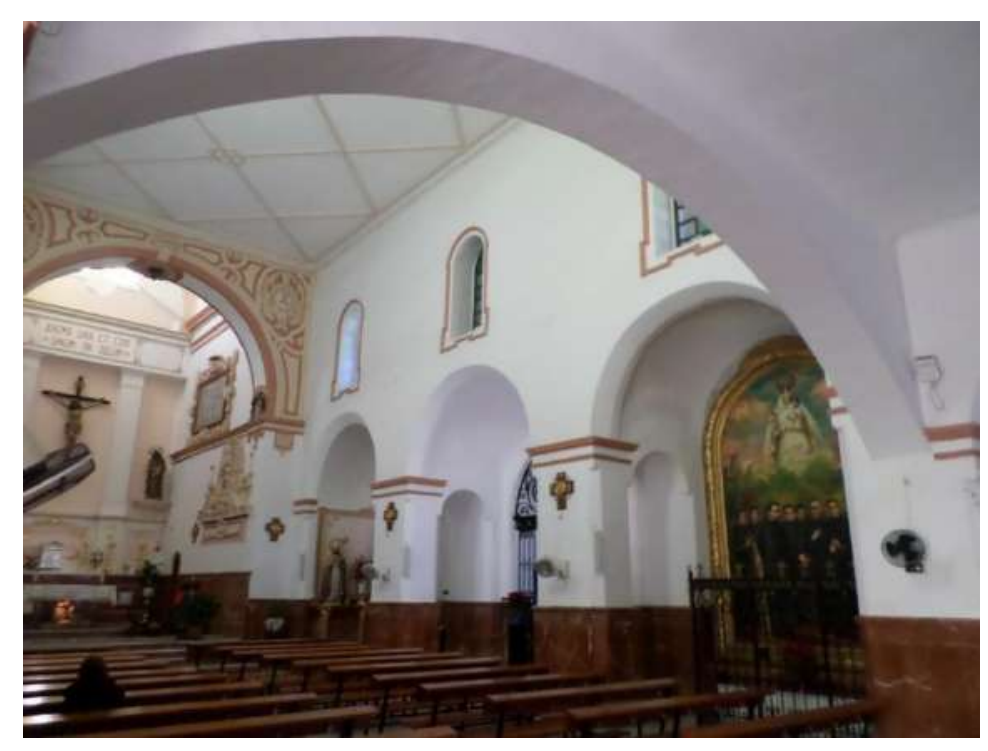

7) Nave de la iglesia.

En el exterior, en primer lugar, en sus laterales, podemos observar la configuración interna de nave única más elevada con respecto a las capillas laterales en la que vemos la diferencia de altura entre ellas. Además, en la fachada principal, de

${ }^{129}$ www.rinconesdegranada.com 
configuración barroca, con una portada en piedra en la puerta de acceso hay dos vanos de arcos de medio punto que la enmarcan y que iluminan interiormente el coro.

También, en esta fachada se encuentran las dos torres en cuyo centro hay un frontón triangular, aunque primitivamente tan solo había una torre, hoy desaparecida.

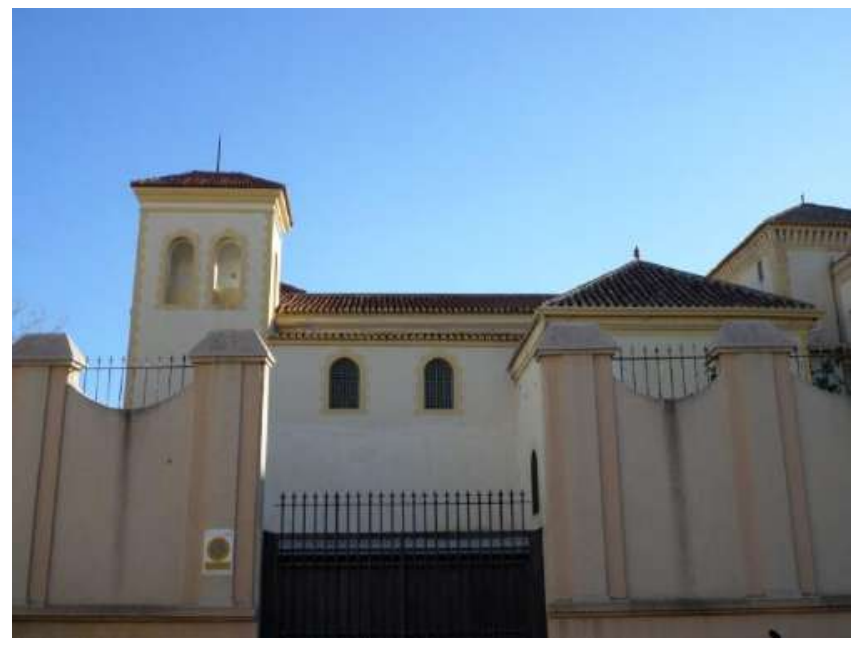

8) Lateral derecho. ${ }^{130}$

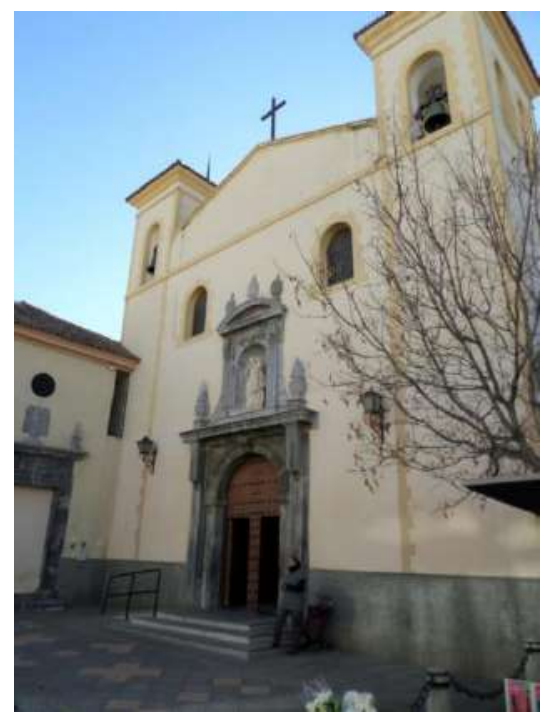

9) Fachada principal.

Pasando al interior del templo, hay que indicar que los muros de la iglesia son gruesos, cumplen la función de cerramiento y sustento del peso, además de que dan gran sensación de solidez. En los muros laterales de la nave principal aparecen cuatro vanos de arcos de medio punto rodeados de cenefas que iluminan el interior. Además, también, esta nave está cubierta por un techo de escayola muy decorado con

${ }^{130}$ En esta foto podemos ver claramente la configuración interna de la nave única más elevada que las capillas entre contrafuertes, además de la Capilla del Sagrado Corazón de Jesús del s. XVIII. 
formas geométricas, pero antes de la Guerra Civil tenía dos armadura, una, de lazo y tracería, que llegaba hasta el comienzo del coro; y otra de par e hilera que cubría el coro, ${ }^{131}$ sin tener más detalle de las mismas, nada más que la reseña que nos ha llegado de las armadura de la nave en el Periódico "El Faro" de 1935: "Fue catalogada como una de más valor de la provincia. Un artículo de prensa así lo especifica: < el pueblo motrileño no se ha dado cuenta todavía de tan precioso monumento, el más artístico y valioso de cuántos existen en nuestra ciudad; y, en su género, el mejor de cuantos existen y hay en la provincia de Granada, no obstante ser la primera de España en “artesonados" mudéjares. Así lo afirma el notable anticuario granadino, señor Fajardo; confirmado la misma opinión de cuantas personas técnicas y entendidas lo han visto y examinado determinadamente" ${ }^{132}$ La capilla mayor está cubierta por una cúpula esférica sostenida por cuatro pechinas. Esta cúpula tiene la peculiaridad de tener dos arcos entrecruzados que la dividen en cuatro partes, muy decorados con diferente simbología, al igual que las cuatro pechinas que presentan escudos nobiliarios. Indicar, por últimos, que dos de las trompas de la cúpula, contienen vanos geminados de medio punto que iluminan la capilla mayor.

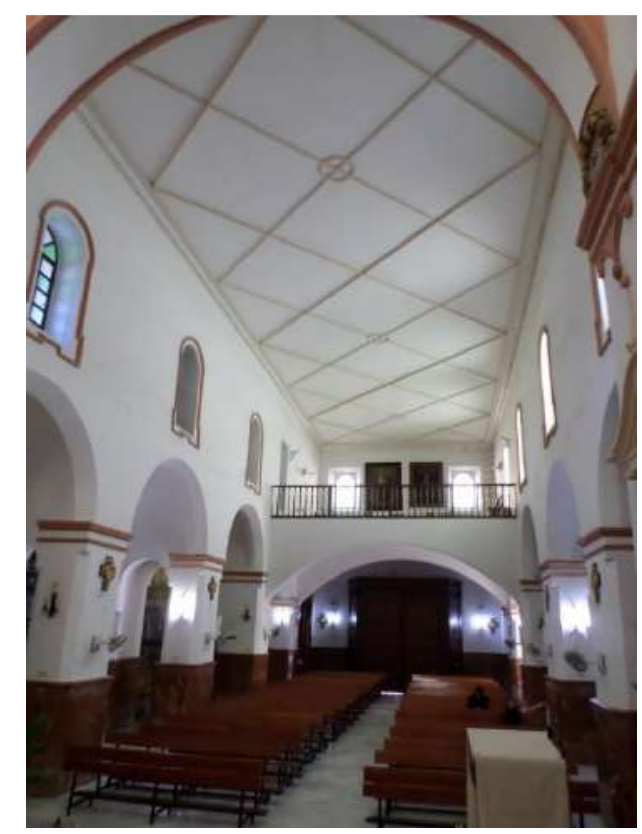

10) Nave de la iglesia desde la capilla mayor. ${ }^{133}$

${ }^{131}$ LÓPEZ FERNÁNDEZ, Domingo A ${ }^{\mathrm{o}}$. "Los Mínimos de San Francisco de Paula. Precedentes .... Op. cit., págs., 187-237.

132 El Faro. 9/10/1935.

${ }^{133}$ En esta foto podemos observar el techo de escayola que sustituye a las dos armaduras que hemos hecho alusión, y también el coro a los pies, además de toda la nave de la iglesia. 


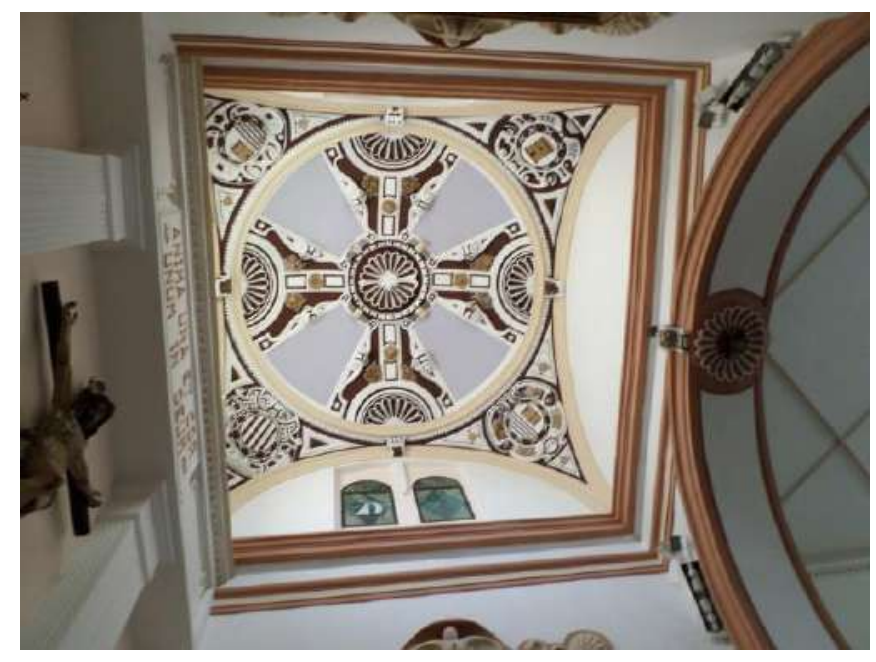

11) Cúpula esférica de la capilla mayor, sostenida por pechinas y trompas.

De la Iglesia de la Victoria, la parte mudéjar sería la estructura del espacio. Del exterior, las cintas de yeso y ladrillo y cajones de mampostería de la que estaba formada antes de finales del s. XIX y que por desgracia desapareció, junto con la única torre que desapareció también en dicho siglo. Del interior, las dos hermosas armaduras que cubrían la nave de la iglesia, actualmente desaparecidas por la contienda de la Guerra Civil española.

\subsection{Iglesia de la Divina Pastora (Convento de Capuchinos) de Motril.}

El s. XVII fue una época de esplendor en Motril, especialmente por el importante desarrollo económico ocasionado por el auge del cultivo de la caña de azúcar, algo que hizo que la población y la importancia de la villa aumentara considerablemente y que las órdenes religiosas pusieran los ojos sobre ella.

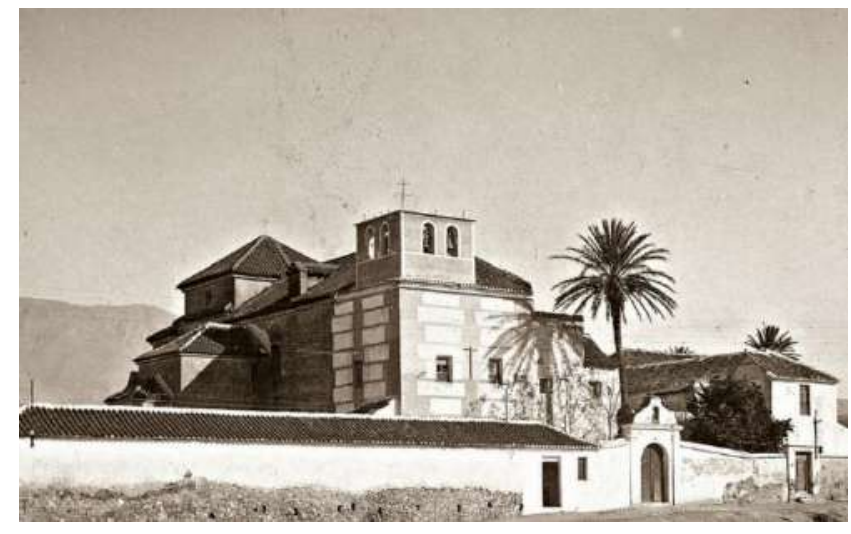

1) Iglesia Divina Pastora a principios del s. XX. ${ }^{134}$

\footnotetext{
134 www.elfaromotril.es
} 
Así, ya estando en ella dos conventos, como eran los Franciscanos y los Mínimos, otra orden quería establecerse, y eran los Franciscanos Capuchinos.

Estos, y tras numerosas contiendas con los otros frailes, consiguieron los permisos para establecerse en Motril y construir su convento, cosa que sucedió en 1644 en la cercanía de la Ermita de San Antonio Abad en el extremo oriental de la villa, donde actualmente está la antigua comisaría de policía.

Decir, que fue el propio Ayuntamiento de Motril el patrono y promotor de la Fundación conventual, y tanto ellos como los religiosos querían que la planta de la iglesia fuera de enorme capacidad para poder albergar un número considerable de personas.

Pero además de eso, debería de construirse una capilla mayor ancha para albergar a los regidores. Aunque la iglesia en cuanto a sus formas y decoración siguió las normas de austeridad y pobreza de la orden capuchina, algo que el arte mudéjar iba a contribuir muy bien en este templo. Pero hemos de decir, que no se conocen quienes fueron los constructores y arquitectos de tal obra. ${ }^{135}$

Los principales materiales de construcción de esta iglesia fueron la piedra, el ladrillo, y el yeso, aunque estos aparecen revocados en la fachada principal, algo que como vemos en la documentación gráfica de principios del s. XX no era así. ${ }^{136}$

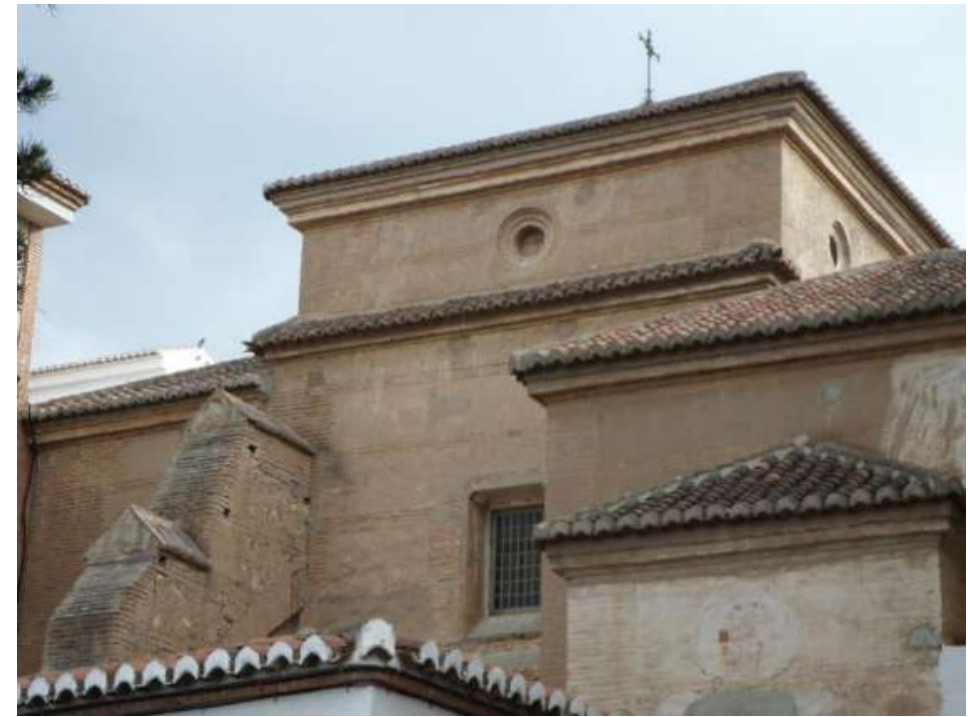

2) Cabecera de la Iglesia, con cintas de ladrillo y cajones de mampostería.

135 VV.AA. El Patrimonio artístico... Op. cit., págs. 159-161.

${ }^{136}$ Ver fotografía "Iglesia de la Divina Pastora a principios del s.XX". 
La iglesia tiene una nave única rectangular sin capilla mayor. ${ }^{137}$ Hemos de indicar que por el lateral izquierdo de la nave se accede por medio de un arco de medio punto de ladrillo a la Capilla de la Virgen de la Pastora de estilo barroco.

También, a través de esta nave se da acceso a la sacristía y a otras dependencias del templo, y a los pies se encuentra el coro sostenido por un arco carpanel pintando de diferente color que el resto de la iglesia, en este caso beige, como la inmensa mayoría de los arcos y elementos decorativos del interior de esta.

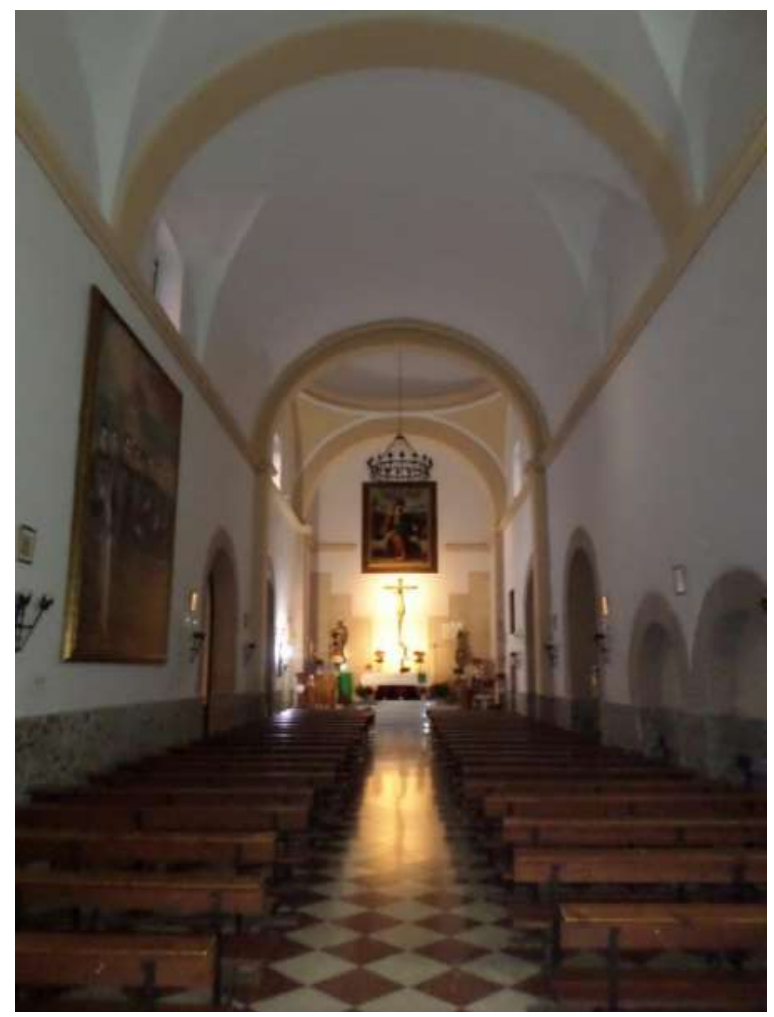

3) Nave de la iglesia.

${ }^{137}$ Este tipo de planta de nave única rectangular sin capilla mayor diferenciada aunque en este caso no cubierta por una armadura sino por una bóveda, como se describe más adelante, respondiendo en cierta medida a las tipologías de planta de iglesias mudéjares de Granada según el estudio realizado por Don Rafael López Guzmán y Don Ignacio Henares Cuéllar en:

- $\quad$ HENARES CUÉLLAR, Ignacio; LÓPEZ GUZMAN, Rafael. Arquitectura Mudéjar.... Op. cit. 


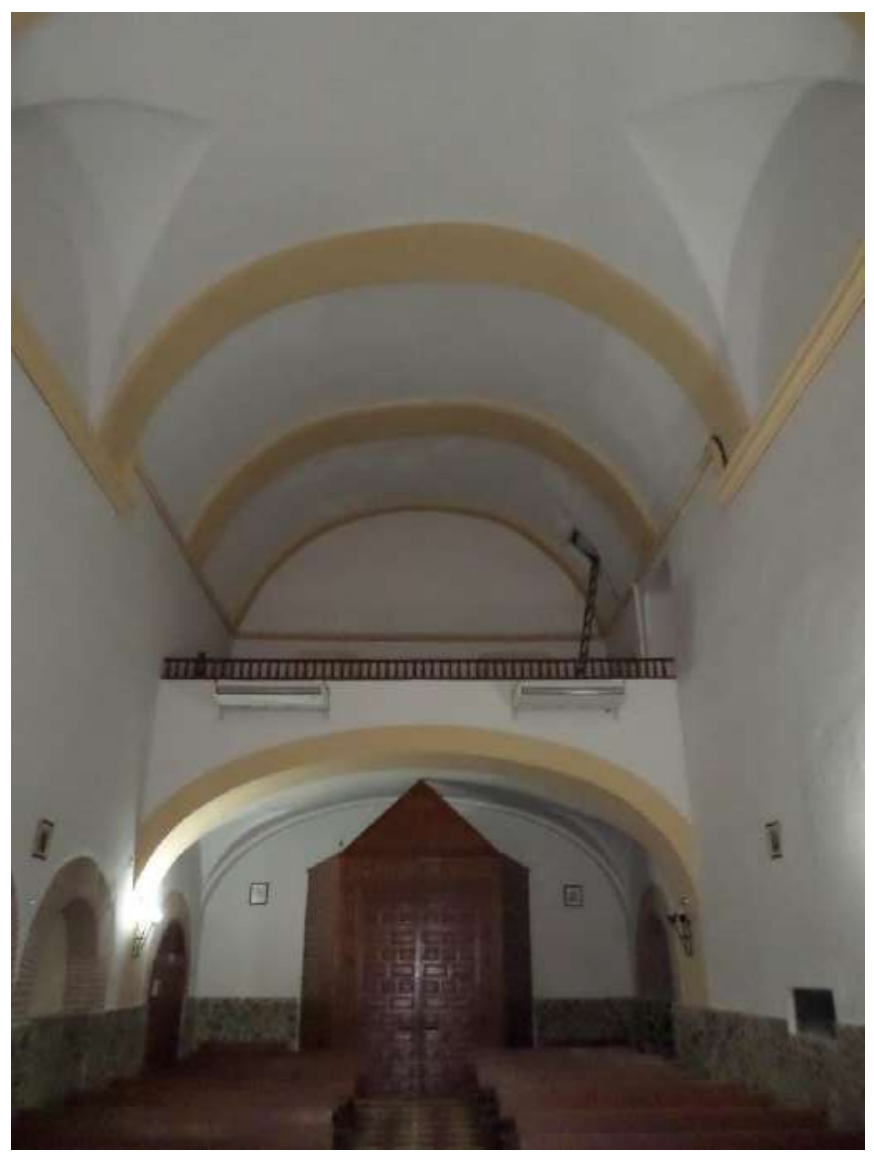

4) Coro.

En el exterior, concretamente en la fachada principal, hay que destacar la puerta principal que está enmarcada por un arco de medio punto de ladrillo (revocado) ${ }^{138}$, rodeado de dos vanos adintelados que iluminan interiormente el coro, también de ladrillo, revocados y pintados de diferente color al blanco de la fachada. Hay que indicar que primitivamente, esta fachada estaba coronada por una cornisa plana donde se ubicaba una espadaña en el lado derecho. ${ }^{139}$ Ésta (la espadaña) tenía cuatro arcos de medio punto en ladrillo, dos hacia el oeste y dos hacia el este, y fue sustituida por la que hoy tiene, más elevada por un frontón triangular y más centrada. Así, la nueva, de ladrillo en toda su estructura, está formada por tres columnas dóricas entre las que se encuentran dos arcos de medio punto que contienen las campanas y que sostienen a su vez un frontón triangular también de ladrillo. El cuerpo de la iglesia y la cabecera están sin revocar y podemos ver las cintas de yeso y ladrillo y cajones de mampostería. ${ }^{140}$

\footnotetext{
${ }^{138}$ Esto lo afirmamos porque al realizar el trabajo de campo percibimos el ladrillo perfectamente.

${ }^{139}$ Ver fotografía de la página 141, "Iglesia de la Divina Pastora a principios del s.XX".

${ }^{140}$ Ver fotografía de la página 142, "Cabecera de la Iglesia, con cintas de ladrillo y cajones de mampostería".
} 


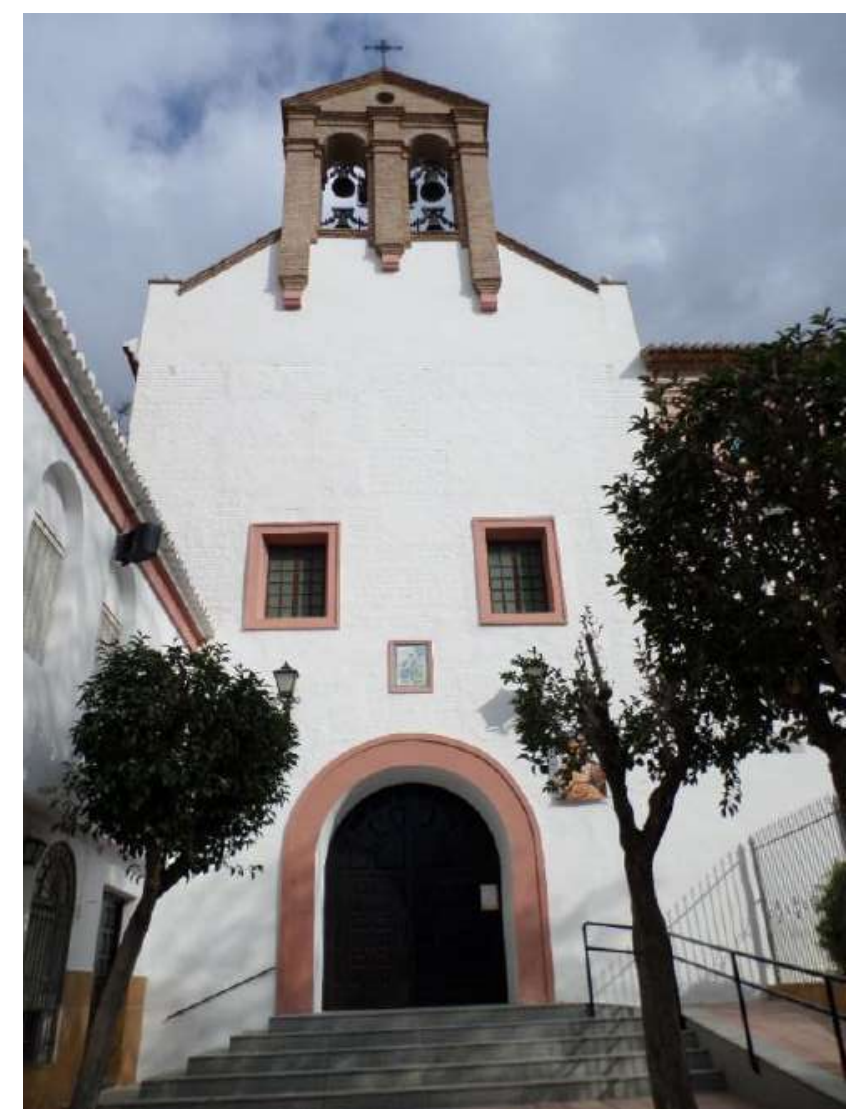

5) Fachada actual de la Iglesia.

Con respecto al interior, hemos de describir que la nave de la iglesia se cubrió con una bóveda de cañón que tiene arcos fajones de distinto color, en este caso amarillo, y rota por una cúpula esférica sostenida por cuatro pechinas y trompas sin ningún tipo de decoración y sostenida por dos arcos de medio punto, colocada sobre cuatro columnas (dos de ladrillo visto y dos de ladrillo, pero revocadas). Hay que indicar que tanto la bóveda como las trompas de la cúpula acaban en una cornisa que recorre toda la nave de la iglesia solo rota en la cabecera de la capilla mayor. A su vez, en esta nave, en los pies del muro derecho vemos cuatro pequeños arcos ciegos de medio punto de ladrillo, y tanto en la parte derecha como en la izquierda dos arcos ciegos de medio punto de gran tamaño que hacen hoy día la función de capillas, también de ladrillo. Todos estos arcos, tanto los pequeños como los de mayor tamaño, descansan sobre un zócalo rústico que recorren a lado y lado de la nave. En la parte superior aparecen dos vanos adintelados que iluminan escasamente el interior. 


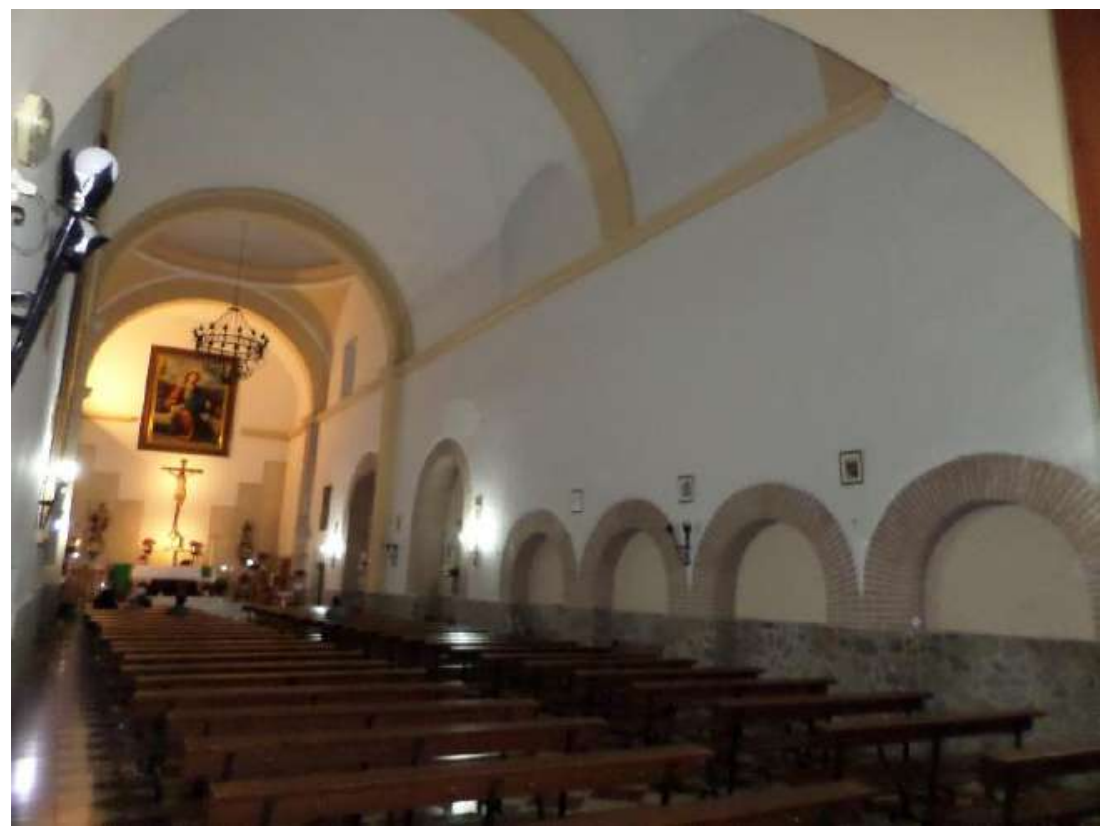

6) Nave de la Iglesia y lado derecho.

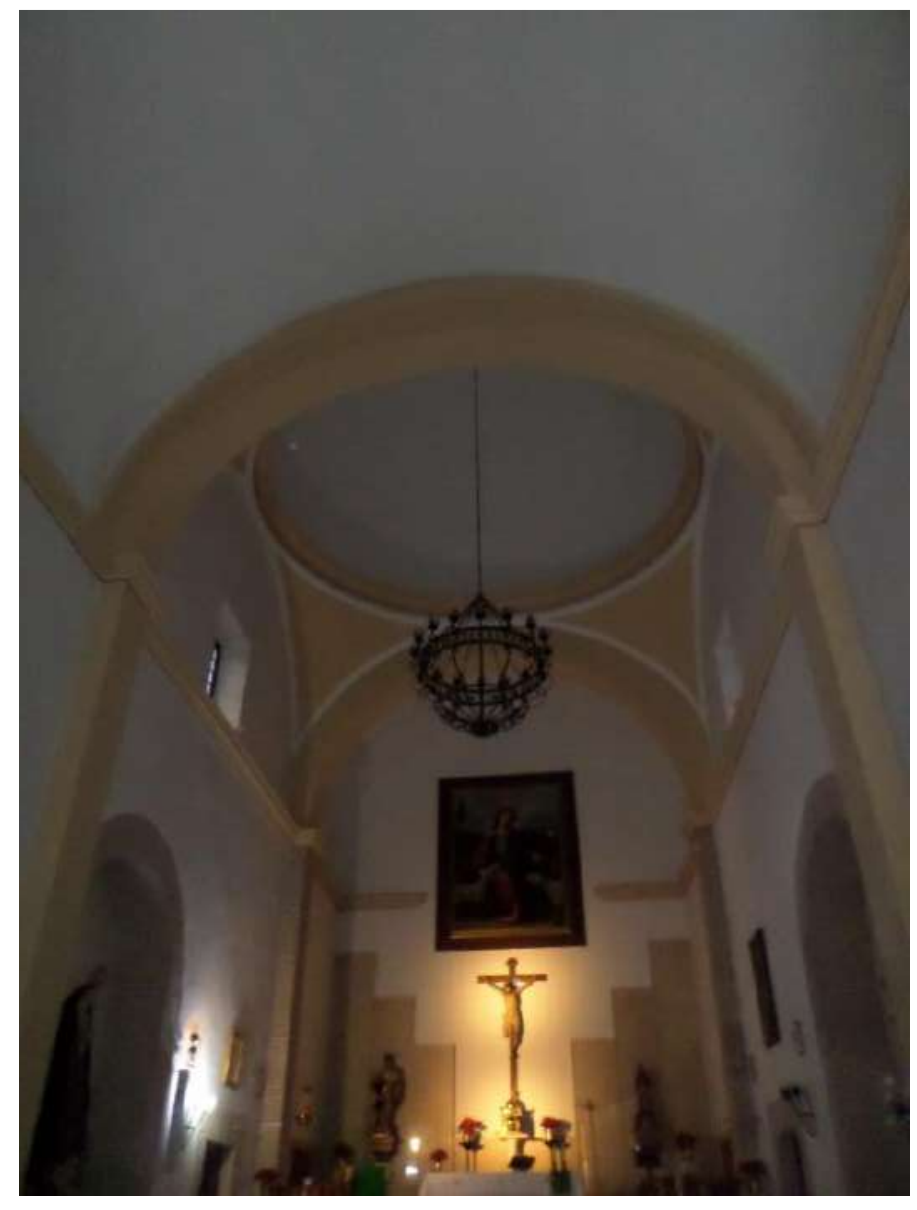

7) Cúpula. 


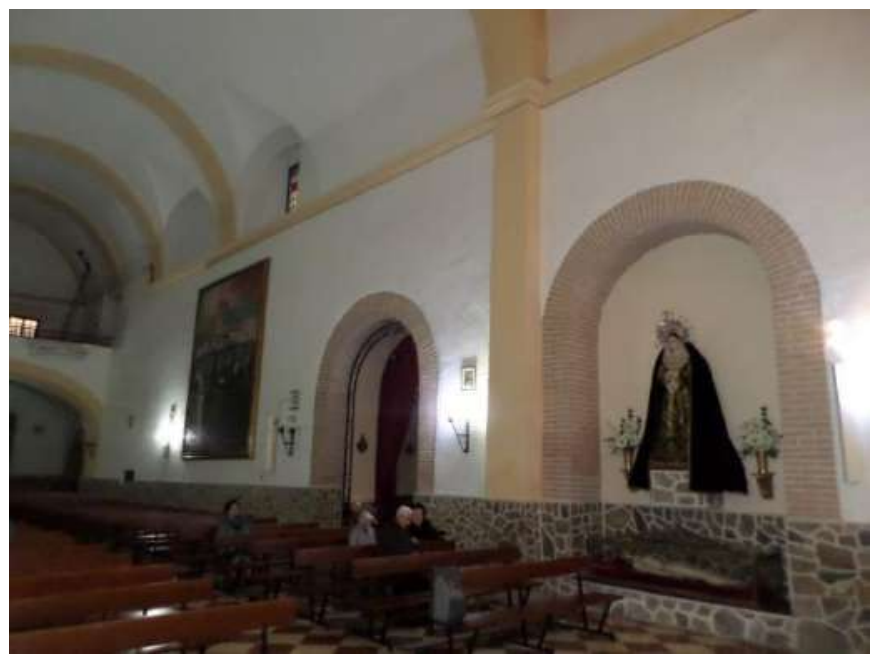

8) Lado izquierdo con acceso a la capilla de la Virgen de la Pastora.

De la iglesia descrita, la parte mudéjar sería, la propia estructura espacial. Del exterior, las cintas de yeso y ladrillo y cajones de mampostería, junto con los predominantes vanos de ladrillo. Del interior, los grandes arcos y dinteles de ladrillo.

\subsection{Iglesia del Santísimo Cristo de Cabrilla de Lújar.}

La Iglesia del Santísimo Cristo de Cabrilla fue construida entre 1614 y $1618^{141}$ en piedra, ladrillo, yeso y madera. Algunos de estos materiales aparecen revocados hoy en día, pero no lo estaban antes de la Guerra Civil española como bien atestiguan los vecinos del pueblo, pudiéndose percibir en el exterior las cintas de yeso y ladrillo y los cajones de mampostería, muy propio de los edificios mudéjares.

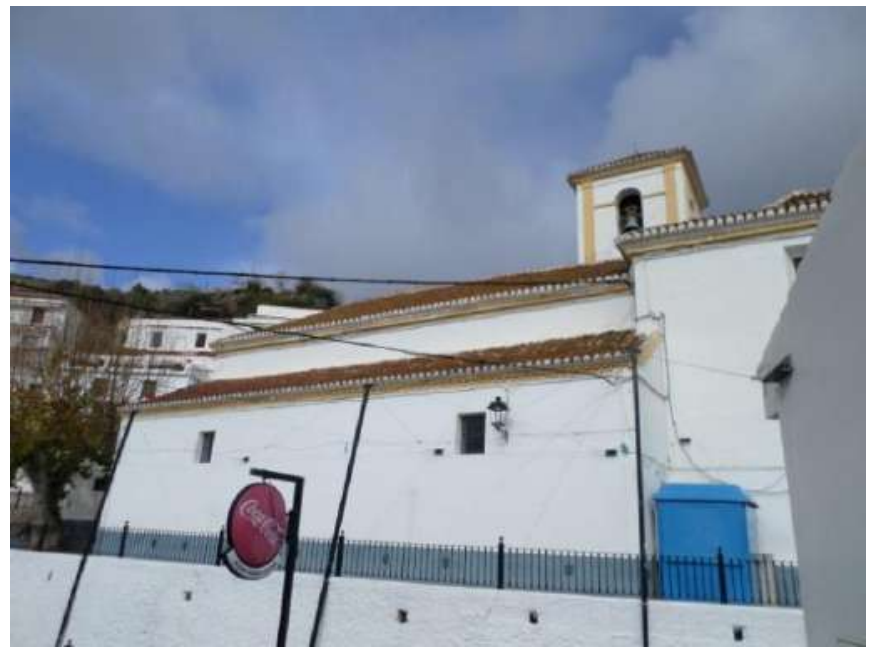

1) Iglesia del Santísimo Cristo de Cabrilla.

${ }^{141}$ VV.AA. Guía artística de Granada y su.... Op. cit., pág. 196. 
La iglesia tiene tres naves y capilla mayor diferencia. ${ }^{142}$ Las naves de la iglesia están separadas por tres arcos de medio punto en el lado derecho y dos arcos de medio punto en el izquierdo sostenidos por pilares cuadrados. La parte superior de los pilares presentan listones de madera, justo donde descansan los arcos. La nave central, que tiene coro alto a los pies, es más elevada y más ancha que las laterales, y estas últimas son fruto, junto con la capilla mayor, de una ampliación que se realizó en el templo en 1798 por el maestro Manuel de Funes. ${ }^{143}$ Esta capilla mayor está en altura y es cuadrada, a ella se accede por medio de un arco toral de medio punto apoyado sobre pilastras con listones también de madera y a través de ella se da paso a la sacristía y a la torre.

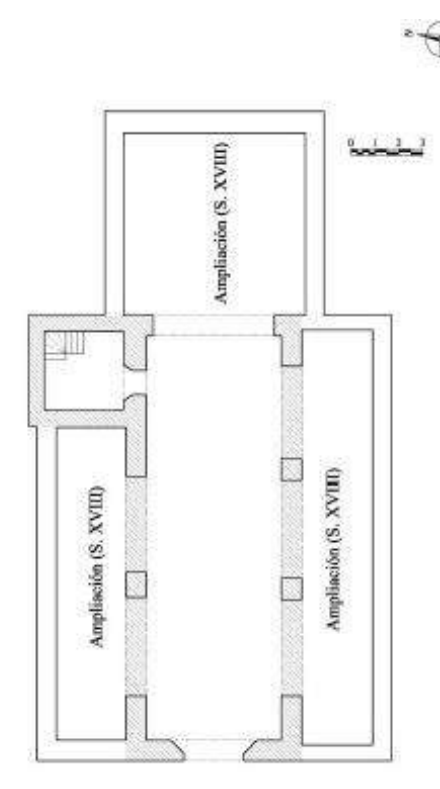

2) Plano de la iglesia ${ }^{144}$

${ }^{142}$ Este tipo de planta de iglesia de tres naves con capilla mayor diferenciada responde a un tipo de Iglesia Mudéjar según el estudio realizado por Don Rafael López Guzmán e Ignacio Henares Cuéllar en: - HENARES CUÉLLAR, Ignacio; LÓPEZ GUZMAN, Rafael. Arquitectura Mudéjar.... Op. cit.

Aunque las naves laterales y la capilla mayor son una ampliación del s. XVIII, como se explica más adelante, por lo que primitivamente tendría una nave única rectangular sin capilla mayor diferenciada, también tipología de iglesia mudéjar de Granada según el estudio realizado por Don Rafael López Guzmán e Ignacio Henares Cuéllar en el mismo documento.

${ }^{143}$ VV.AA. Guía artística de Granada y su.... Op. cit., pág. 196.

${ }^{144}$ MARTÍN GARCÍA, Mariano. "Iglesias Fortificadas.... Op. cit., pág. 732. 


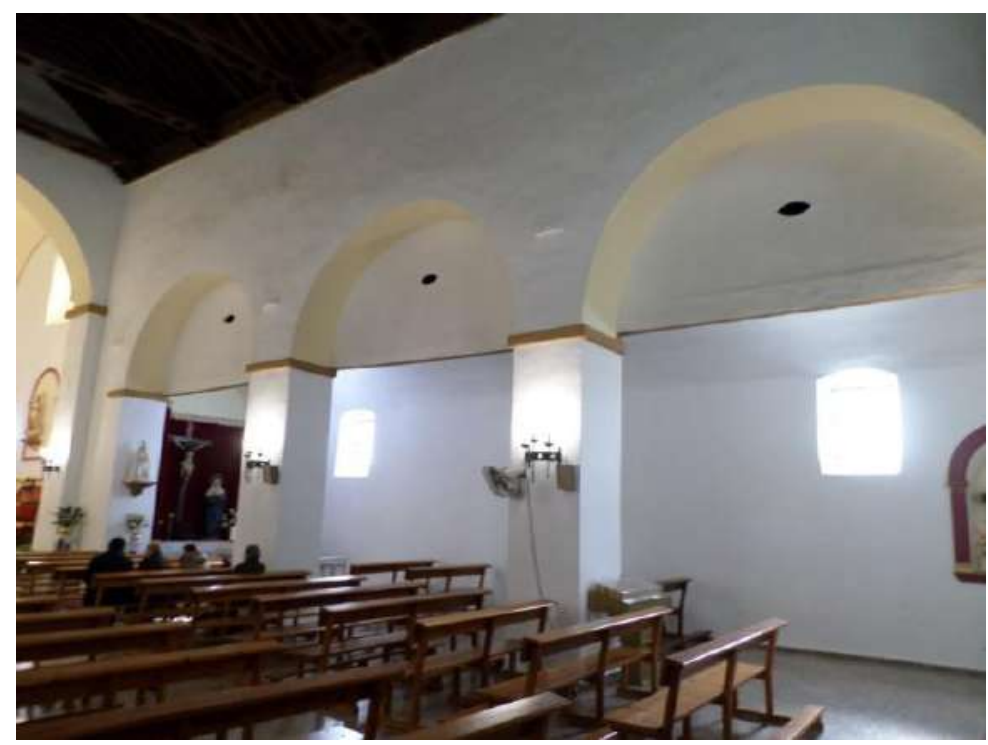

3) Acceso a naves laterales.

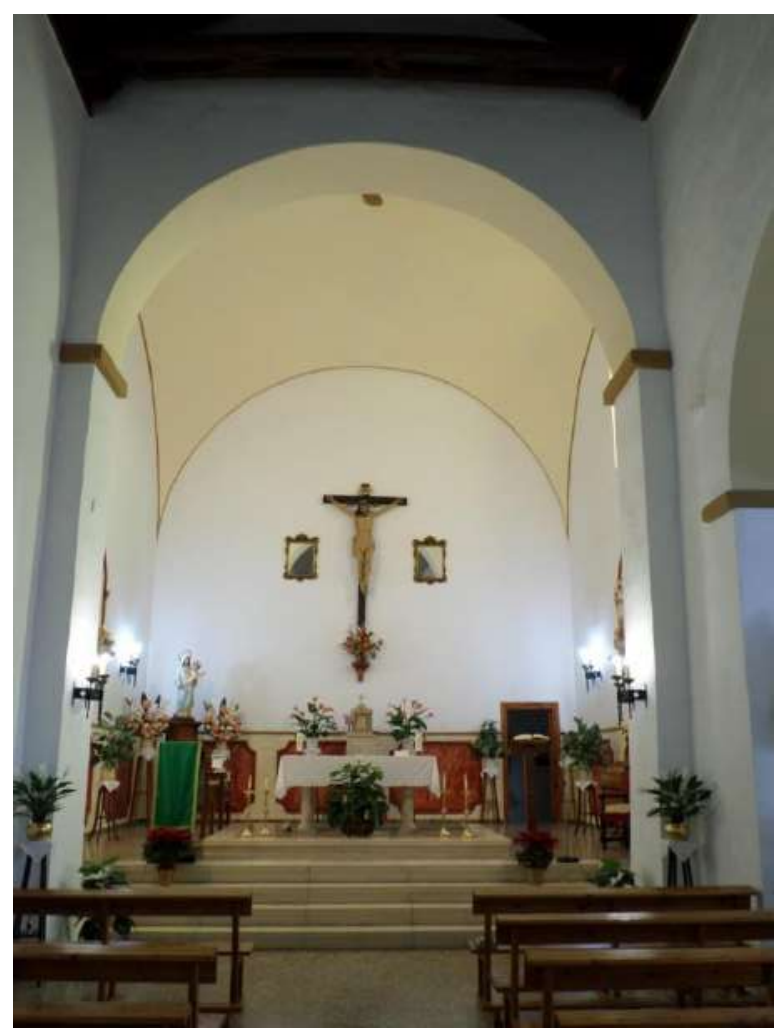

4) Capilla mayor.

En el exterior del templo podemos observar claramente la configuración interna de tres naves ya que vemos como sobresale la nave central con respecto a las dos naves laterales. También percibimos como la puerta de acceso se encuentra enmarcada por un arco de medio punto sostenido por columnas dóricas con un vano de medio punto en su parte superior que ilumina interiormente el coro, todo construido en ladrillo, aunque revocado como hemos indicado al comienzo de la descripción. 


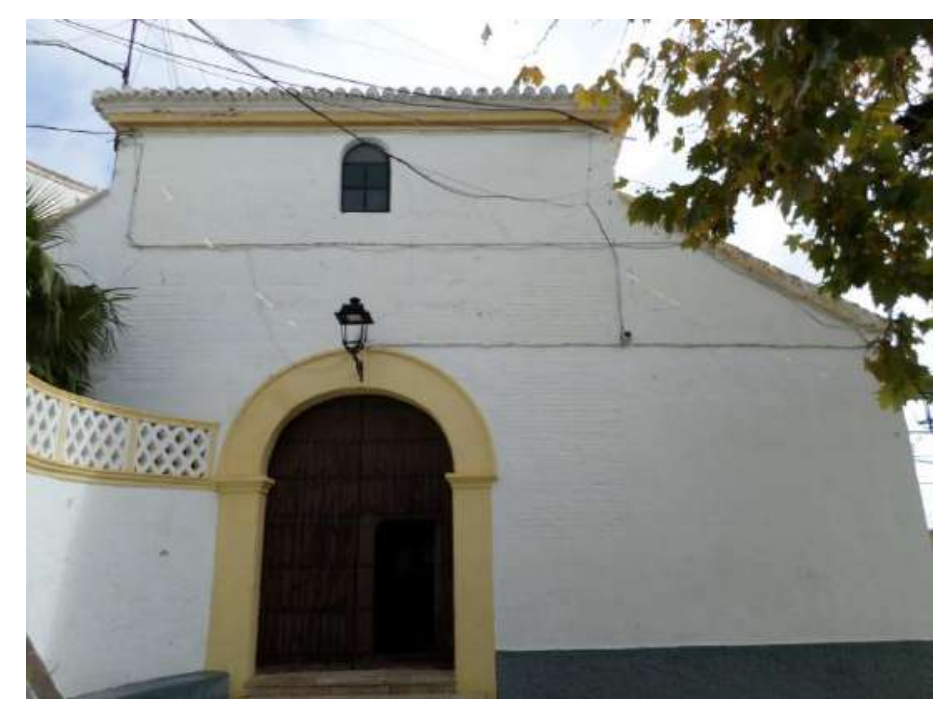

5) Fachada principal.

Pasando a comentar el interior, hemos de indicar que los muros de la iglesia son gruesos y cumplen con la función de cerramiento y sustento del peso de los elementos superiores, además de que dan gran sensación de solidez. El muro exterior izquierdo presenta dos vanos adintelados que iluminan el interior junto con otro que aparece en la parte de la capilla mayor. La nave central está cubierta por una gran armadura de lima bordón con tirantes pareados que contienen decoración de lazo de diferentes formas con un único azafate cada lazo y chillas y apoyados en canes lobulados, también presenta cuadrales dobles con decoración de lazo, aunque en los pares no se encuentra decoración, siendo una armadura llana, aunque si presenta almizate, pero sin decoración. Fue realizada en 1660 por el carpintero Diego Ximénez. ${ }^{145}$ El coro está sostenido por un alfarje con una primera y única jácena, sin canes y diez jaldetas sobre las que se colocan las tablazones sin ningún tipo de decoración y muy simple.

Actualmente este alfarje está parcialmente cubierto por un sotocoro. Las naves laterales presentan bóvedas de cañón sin decoración, con una franja dorada en el lugar donde descargan el peso en los pilares laterales. A su vez, la capilla mayor tiene una bóveda vaída en cuyo centro hay una decoración en forma de flor de color dorada y una franja que rodea la bóveda que marca su contorno del mismo color.

${ }^{145}$ VV.AA. Guía artística de Granada y su.... Op. cit., pág. 196. 


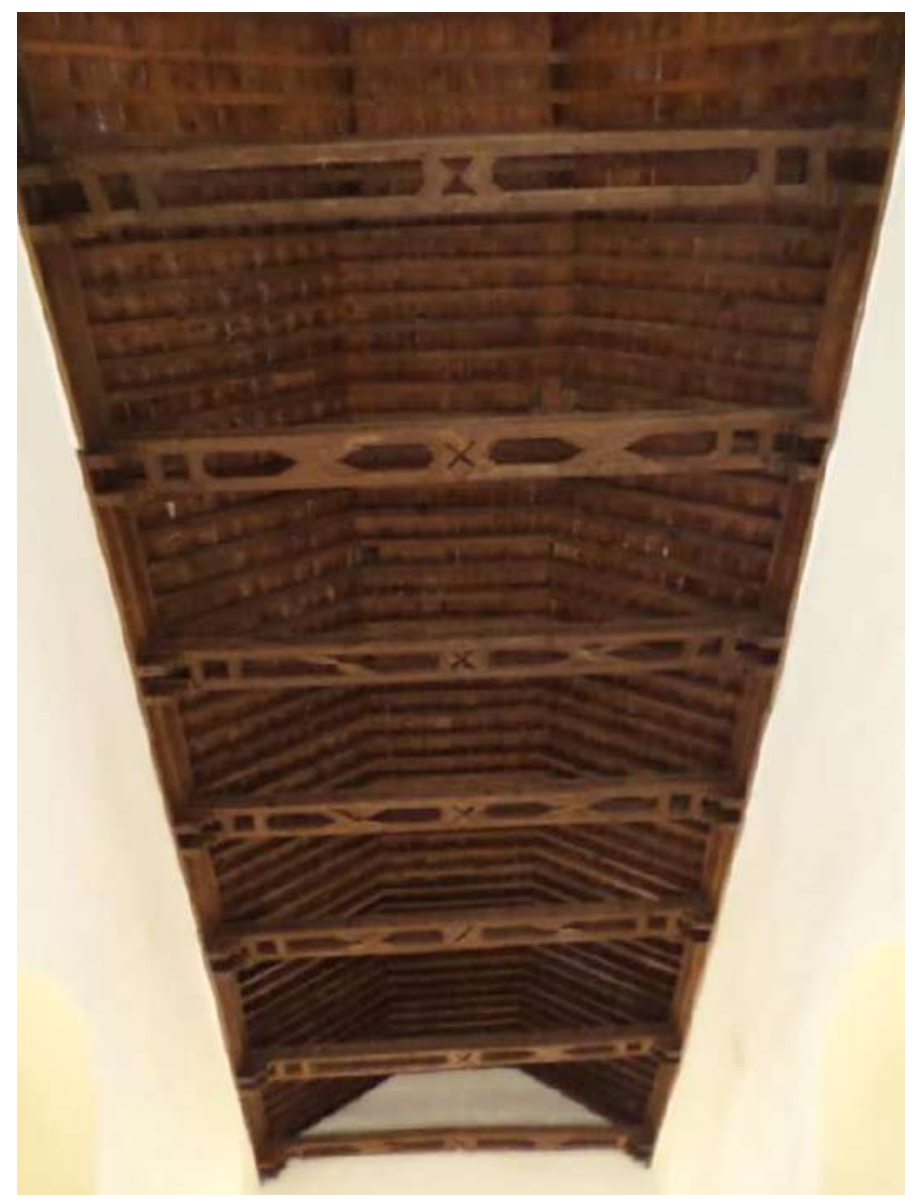

6) Vista general de la armadura de la nave central de la iglesia.

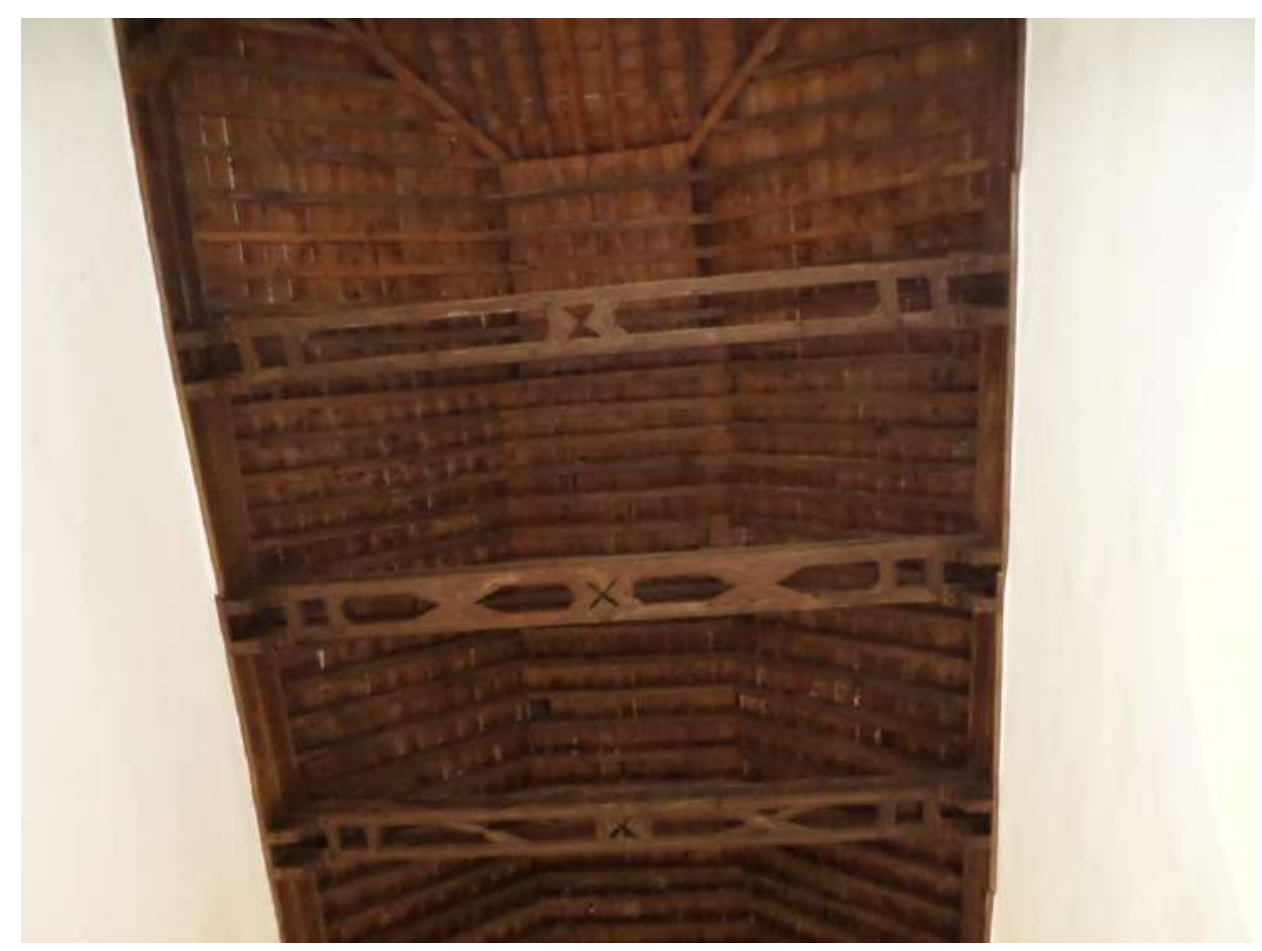

7) Detalle de la armadura de la nave central de la iglesia. 


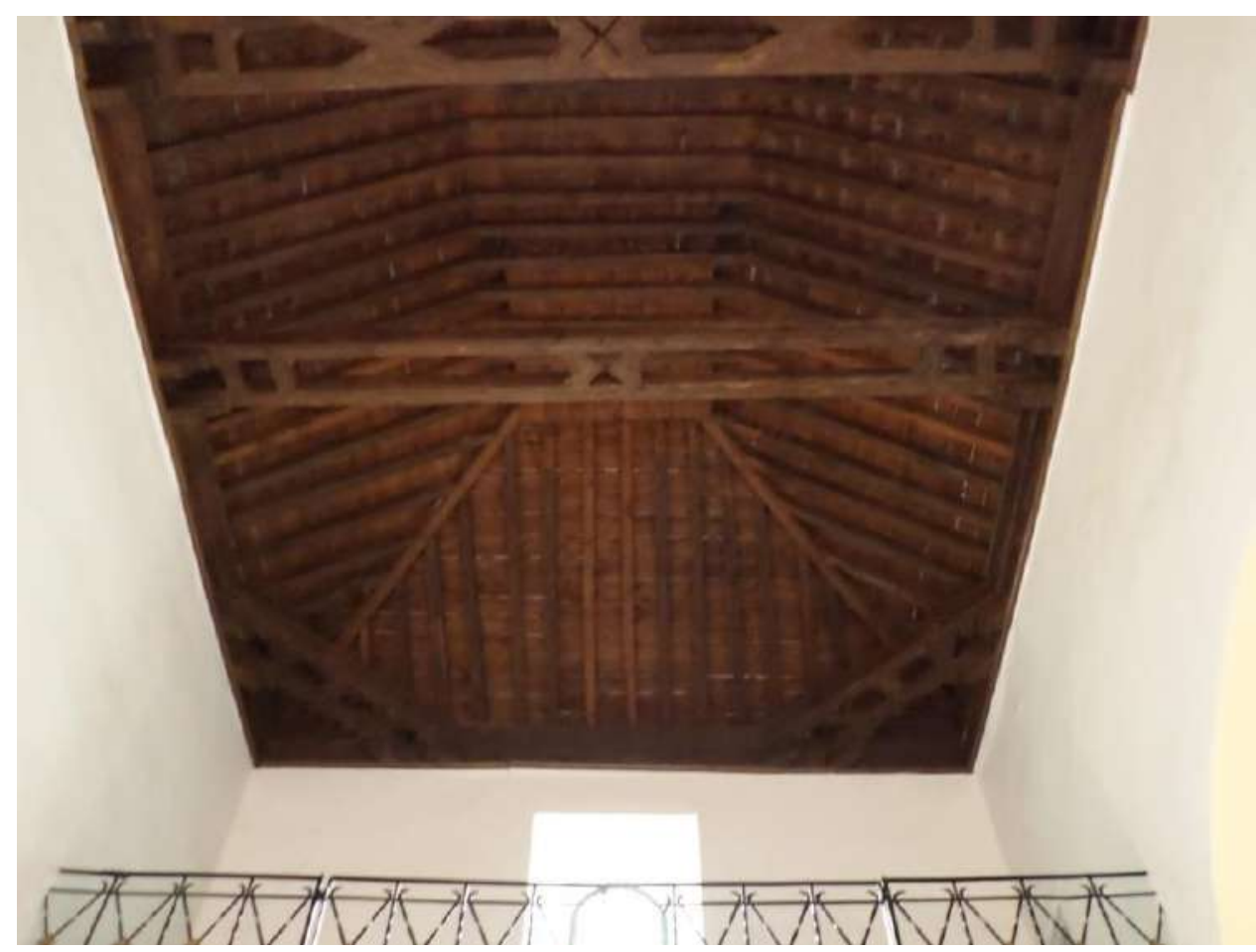

8) Detalle de encima del coro de la armadura de la nave central de la iglesia.

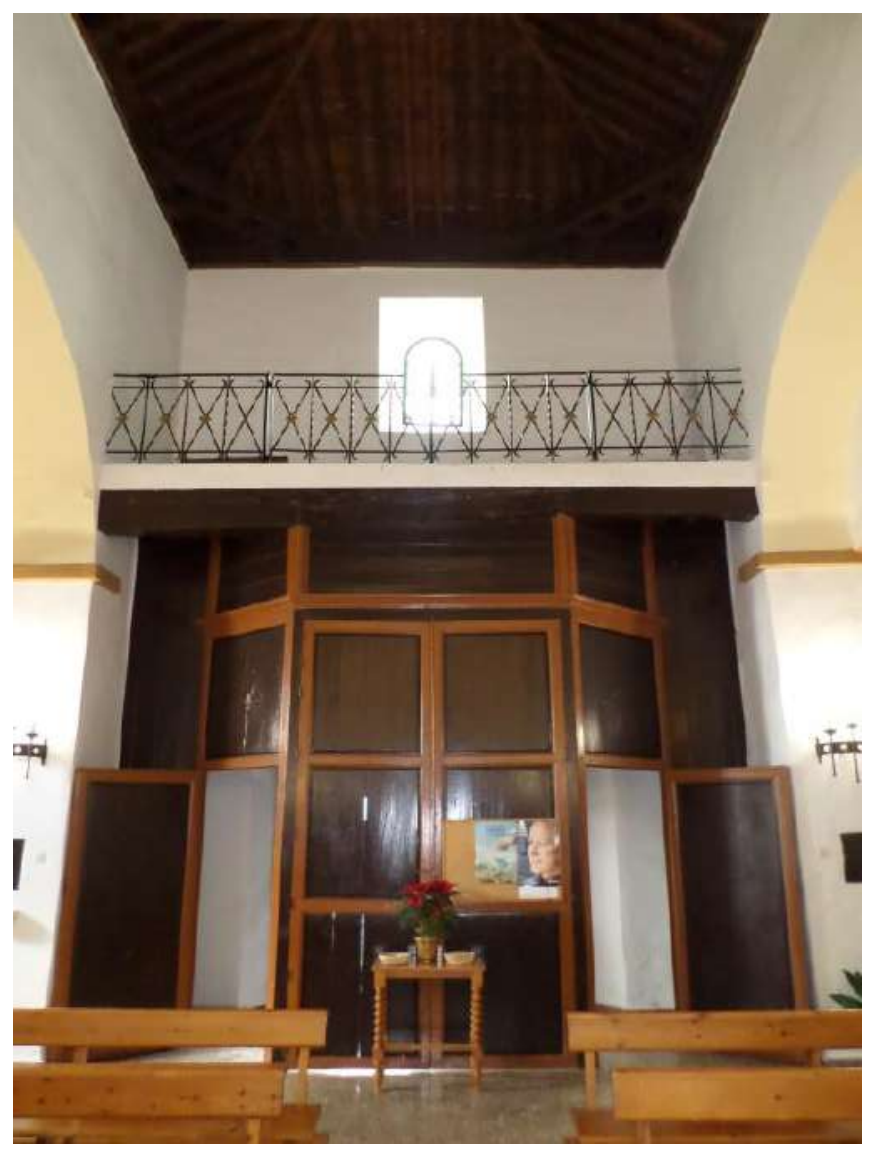

9) Alfarje cubierto por el sotocoro. 


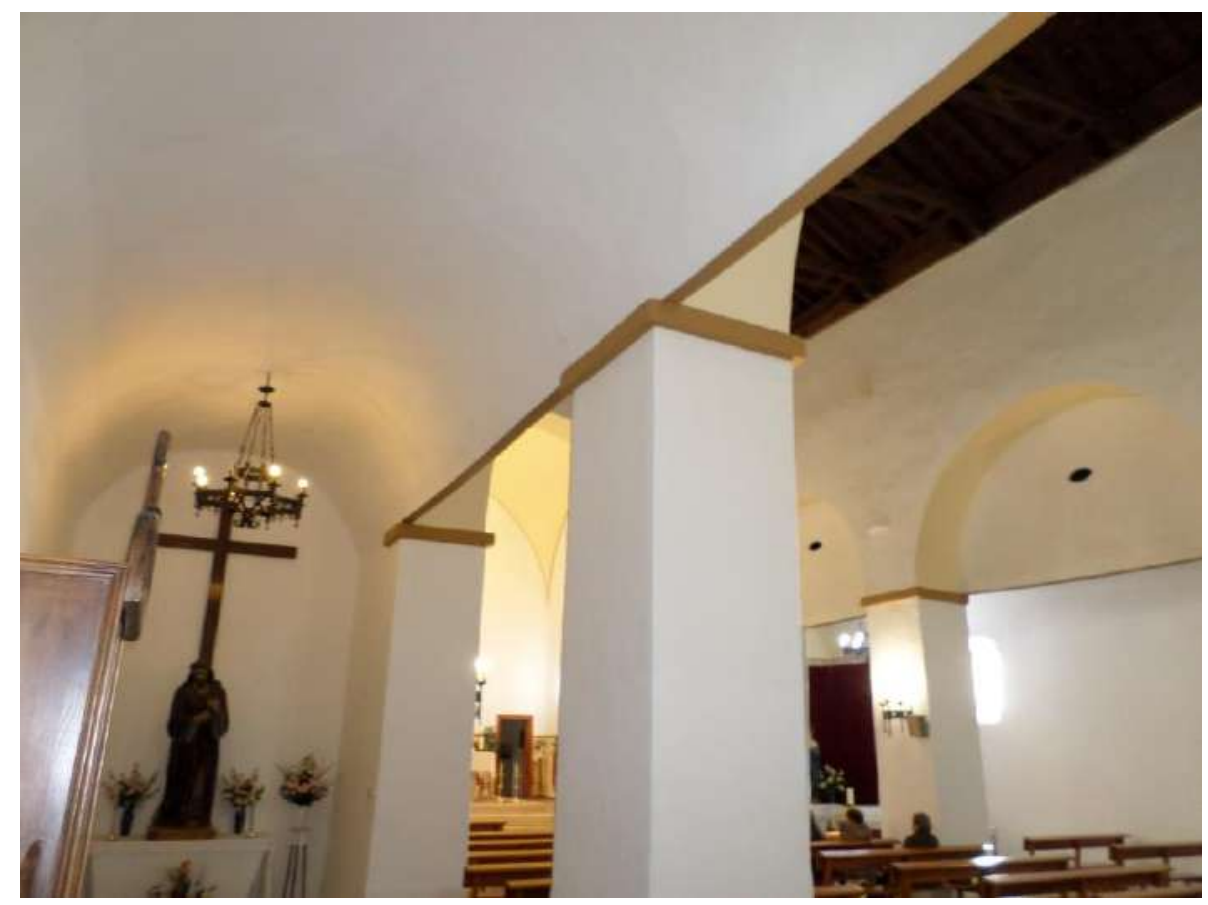

10) Nave lateral izquierda y su bóveda de cañón.

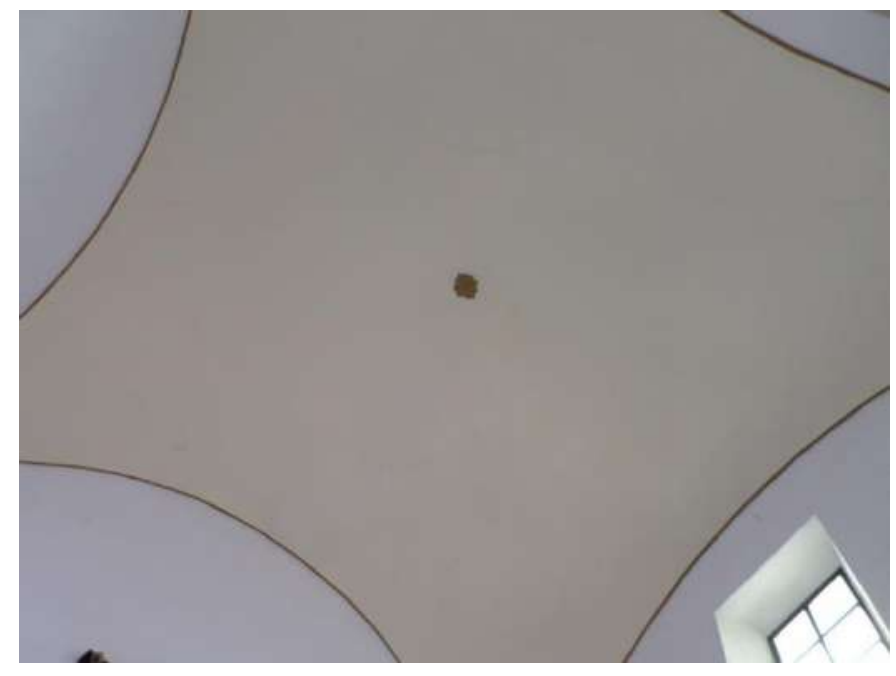

11) Bóveda vaída de la capilla mayor.

Por último, pasamos a describir la torre-campanario que se encuentra situada en el lado NO de la iglesia. Las cintas de yeso y ladrillo y cajones de mampostería son sus materiales de construcción, aunque también aparecen revocados hoy en día. Esta torre tiene tres cuerpos separados por cornisas, el segundo cuerpo tiene un arquillo de medio punto, y el tercer cuerpo tiene un arco de medio punto en sus cuatro lados donde se sitúan las campanas. 
La Iglesia de Santísimo Cristo de Cabrilla es un templo que apenas ha sufrido transformación a pesar del paso del tiempo, y eso hace que sea uno de los templos mejor conservados del mudéjar, ya que solo está revocado, a diferencia de otros templos.

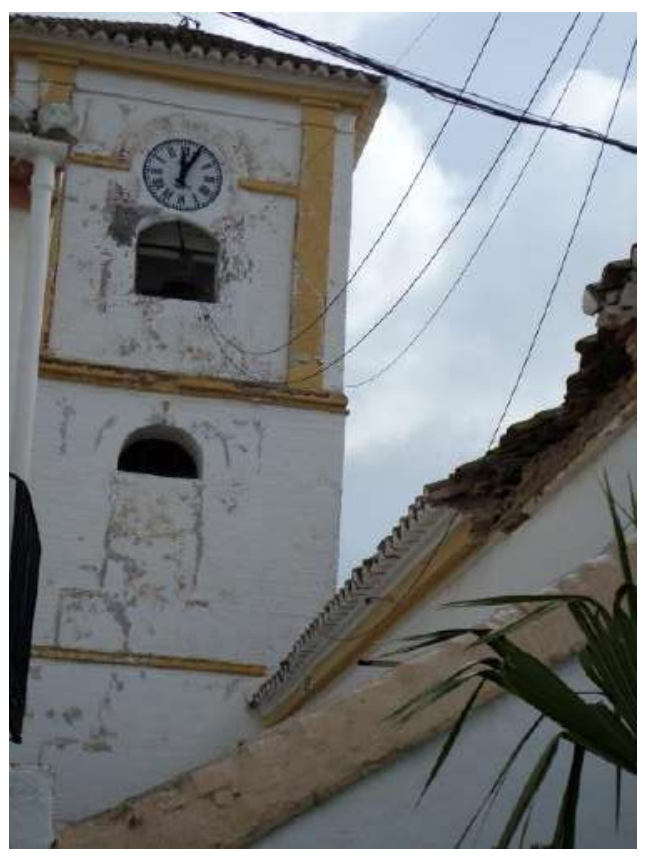

12) Torre.

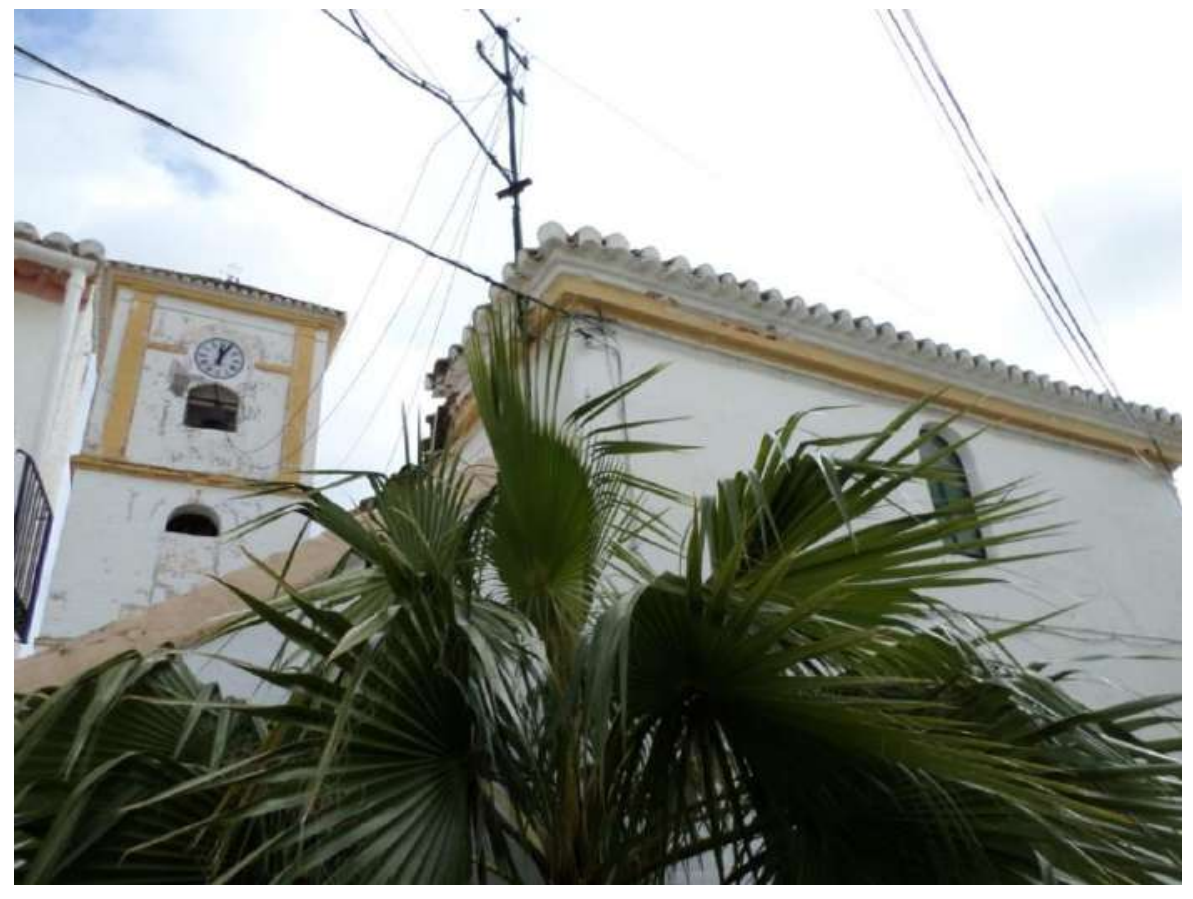

13) Vista de la torre.

De la iglesia descrita, la parte mudéjar es, la estructura espacial. Del exterior, las cintas de yeso y ladrillo y cajones de mampostería, y la fachada principal 
predominantemente decorada, junto con la gran torre. Del interior, la antigua armadura de la nave principal y el conservado alfarje que sostiene el coro.

\subsection{Iglesia Parroquial de San Miguel de Gualchos.}

La actual Iglesia Parroquial de San Miguel de Gualchos es una construcción de 1614 sobre las ruinas de la primitiva iglesia mandada construir por los Reyes Católicos en 1502 según nos relata Pascual Madoz. ${ }^{146}$ El proyecto de esta nueva iglesia fue de Juan Luis de Ortega, ${ }^{147}$ aunque también trabajó el carpintero Francisco González Salazar. ${ }^{148}$

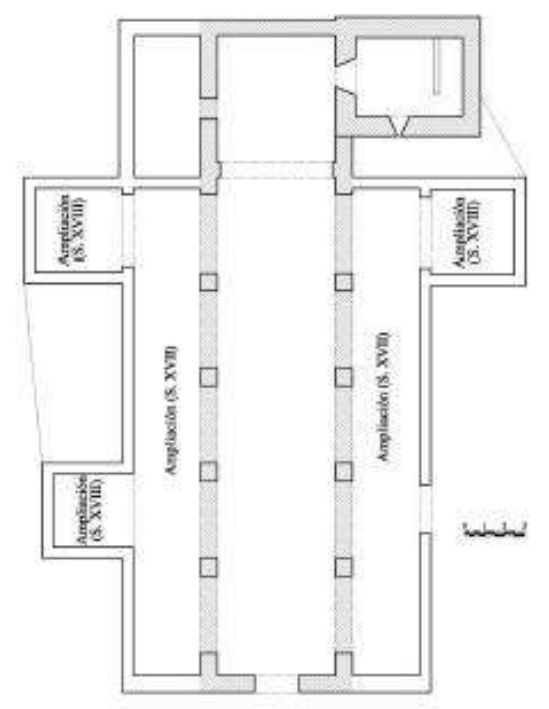

1) Plano de la iglesia. ${ }^{149}$

Los principales materiales de construcción que se han utilizado en la iglesia son la piedra, el ladrillo, el yeso y la madera. Pero sabemos por testimonios

${ }^{146}$ MADOZ, Pascual. Diccionario Geográfico-Estadístico-Histórico de España y sus posesiones en Ultramar: Granada: El nombre del imp. varía en diferentes vols. Vols. 6-9: Est. Tipográfico-Literario Universal; Vols. 10-11: Imprenta al Diccionario Geográfico, a cargo de José Rojas; Vols. 12-16: Imprenta del Diccionario geográfico estadístico-histórico de Pascual Madoz, 1846-1850. pág. 205.

${ }^{147}$ SÁNCHEZ REAL, Javier. Iglesia y defensa: las iglesias-fortaleza del Reino de Granada. En: BARRIOS AGUILERA, Manuel (Coord.), GALÁN SÁNCHEZ, Ángel (Coord.), La historia del reino de Granada a debate: viejos y nuevos temas: perspectivas de estudio. Granada: Editorial Actas, 2004., págs. 595-626., pág. 625.

${ }^{148}$ MARTÍN GARCÍA, Mariano. "Iglesias Fortificadas.... Op. cit., pág. 719.

${ }^{149}$ Ibídem. pág., 732. 
vecinales que la piedra y el ladrillo de la fachada están revocados, y la madera de la armadura desaparecida en la Guerra Civil.

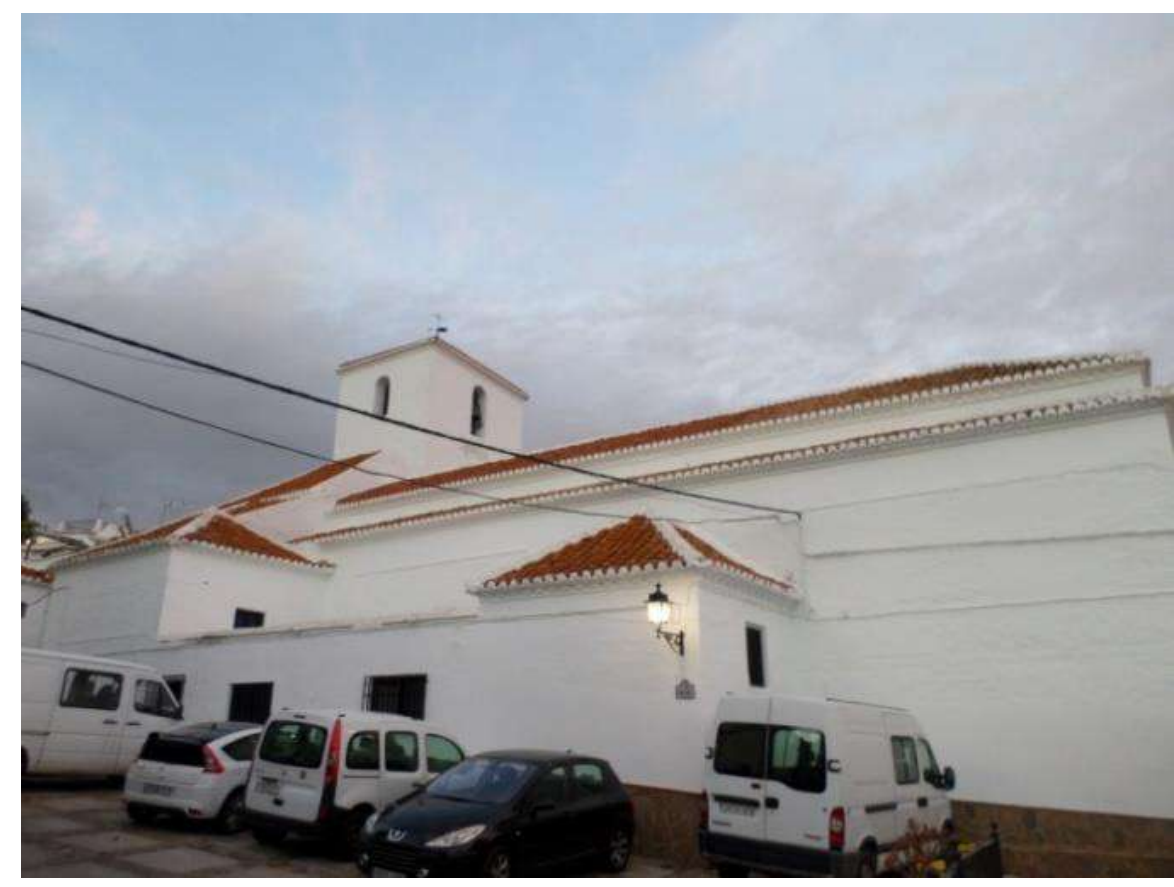

2) Vista externa de la iglesia.

La iglesia tiene tres naves y capilla mayor diferenciada. ${ }^{150}$ La nave central es central más alta y ancha y las laterales son de menor altura y tamaño y a las que se accede desde la nave principal por medio de cinco arcos de medio punto que se apoyan en columnas cuadradas. Estos arcos y columnas presentan decoración al fresco que imita el mármol de diferentes colores. También, a través de la nave central se da paso a la capilla mayor cuadrada por medio de un arco toral de medio punto sostenido por pilastras, decorados de la misma manera que los de la nave central. A través de la capilla mayor se accede a la sacristía y a la torre. A su vez, a los pies de la nave principal se sitúa un coro alto. Hemos de destacar que en el s. XVII se produce la ampliación de las naves laterales, y en 1763 las ampliaciones con la construcción de la

${ }^{150}$ Este tipo de planta de iglesia de tres naves con capilla mayor diferenciada responde a un tipo de Iglesia Mudéjar según el estudio realizado por Don Rafael López Guzmán e Ignacio Henares Cuéllar en:

- $\quad$ HENARES CUÉLLAR, Ignacio; LÓPEZ GUZMAN, Rafael. Arquitectura Mudéjar.... Op. cit.

Aunque las naves laterales s. XVII, como se explica más adelante, por lo que primitivamente tendría una nave única rectangular cubierta por una armadura y con capilla mayor diferenciada, también tipología de iglesia mudéjar de Granada según el estudio realizado por Don Rafael López Guzmán e Ignacio Henares Cuéllar en el mismo documento. 
Capilla Bautismal y la Capilla de San José (actual Capilla del Santísimo) en la nave lateral izquierda y la Capilla de San Miguel en la nave lateral derecha. ${ }^{151}$

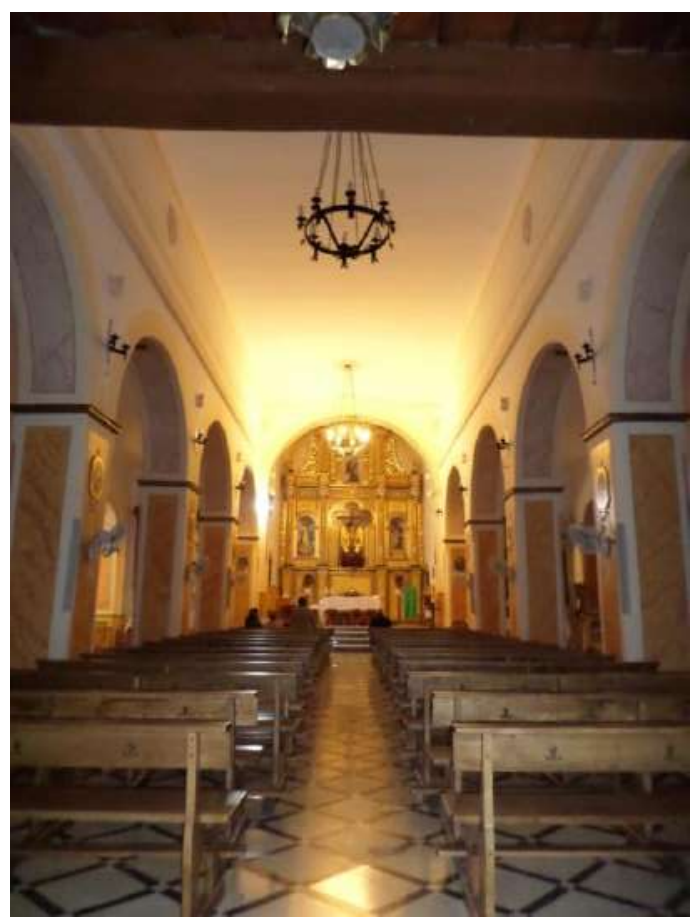

3) Nave central de la iglesia.

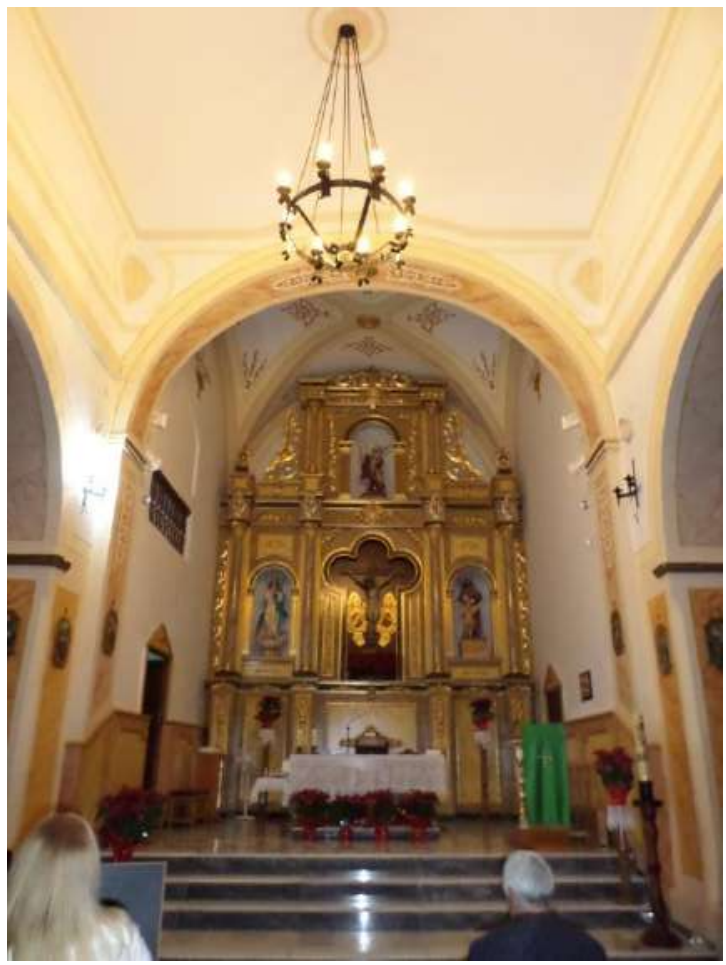

4) Capilla mayor.

${ }^{151}$ VV.AA. Guía artística de Granada y su.... Op. cit., pág. 194. 


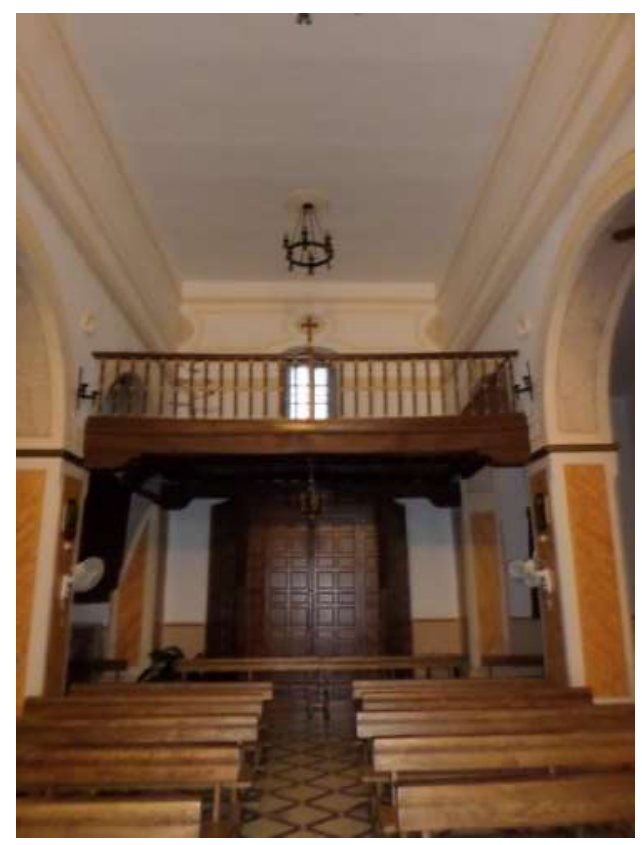

5) Coro.

En el exterior, nos encontramos con dos portadas, una situada a los pies o fachada sur y otra en el lado derecho o fachada este. La portada que se sitúa a los pies tiene un acceso por dos cuerpos de escaleras, con la puerta en la conjunción de ambas. La puerta está enmarcada por un arco de medio punto sostenido por dos pilares dóricos y rodeado, a su vez, por pilares que sostienen una cornisa, apareciendo todo revocado. ${ }^{152}$ Encima de dicha puerta hay una ventana adintelada y en los laterales extremos también, iluminando el interior. En esta fachada sur se puede percibir y observar de forma clara la configuración interna de la iglesia con una nave principal más elevada en altura y más ancha que las laterales que son más bajas y estrechas, ya que vemos esas diferencias en la propia fachada. La portada del lado derecho o del este, en cambio tiene un acceso por medio de un solo cuerpo de escalones y una rampa y en ella hay una puerta enmarcada por un arco carpanel sostenido por dos pilares dóricos revocado y que parece fusionarse con la pared. ${ }^{153}$ En su parte superior se sitúa una hornacina con pilares dóricos que sostienen un frontón triangular, y en el extremo derecho de la puerta un vano adintelado que ilumina interiormente la nave lateral derecha.

\footnotetext{
${ }^{152}$ No sabemos si antes de la Guerra Civil español se vería el ladrillo o no que la constituyen interiormente, y que se puede percibir a simple vista en el trabajo de campo que se ha realizado. ${ }^{153}$ Ibídem.
} 


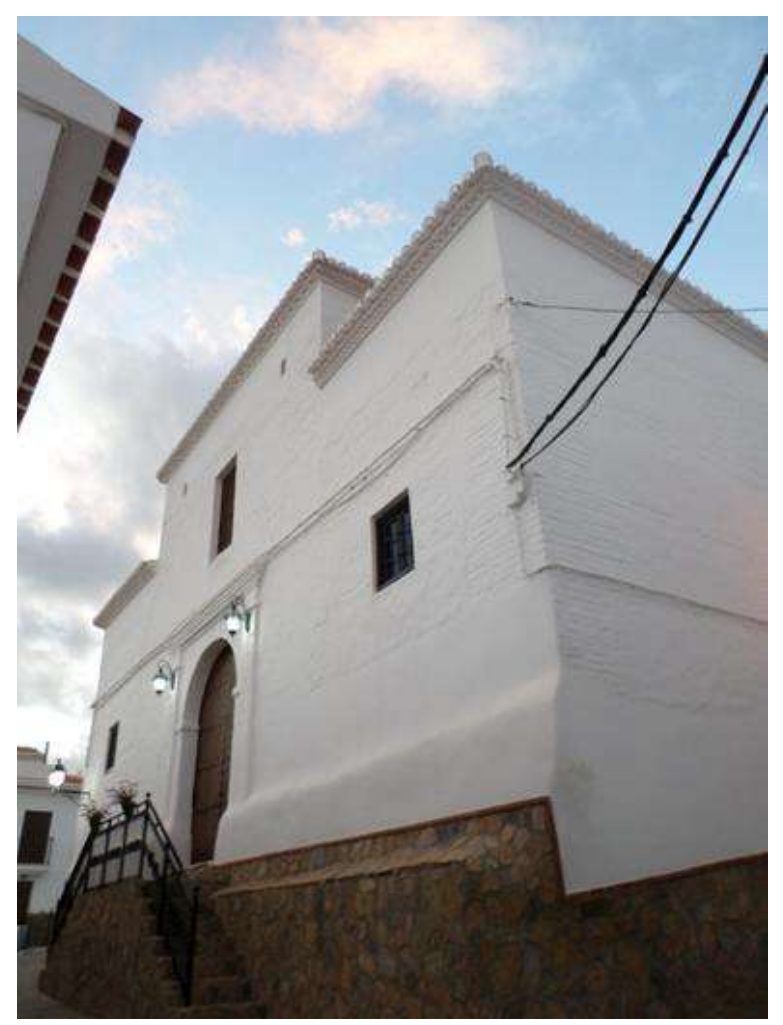

6) Fachada sur.

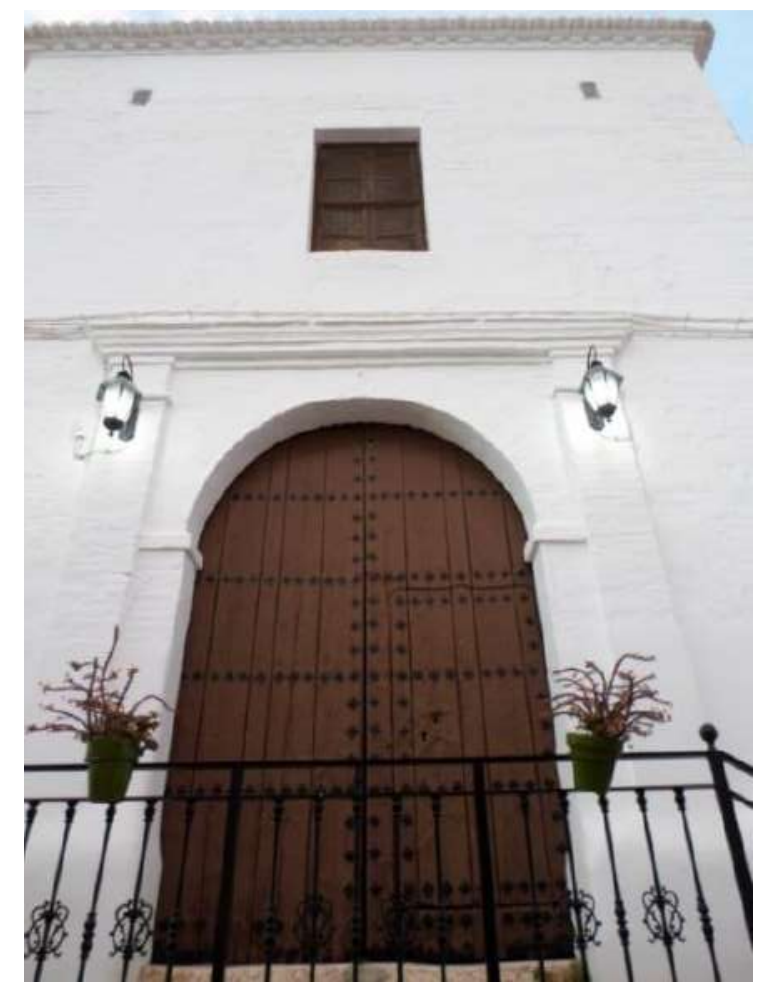

7) Portada sur. 


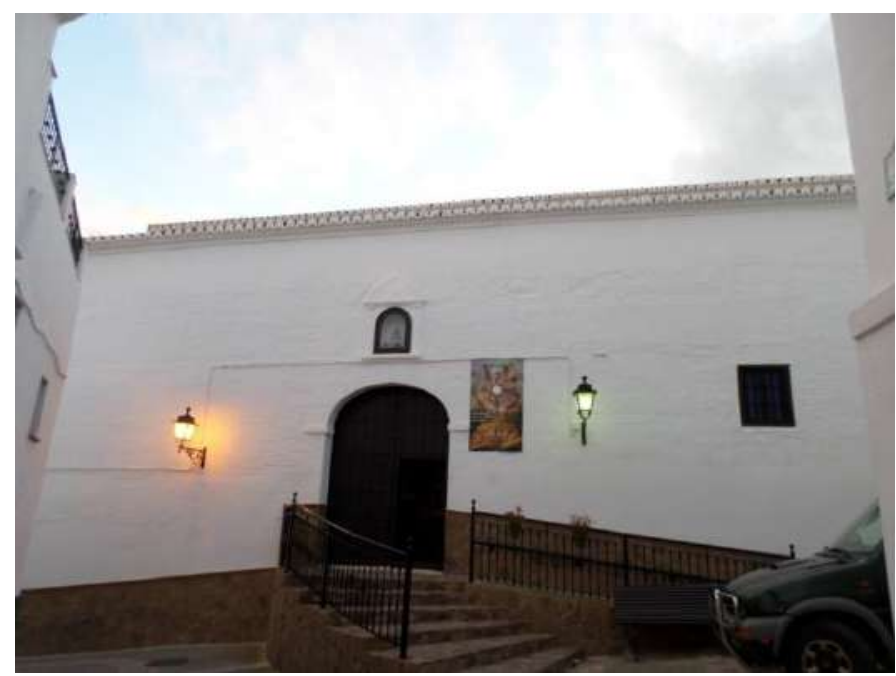

8) Fachada Este.

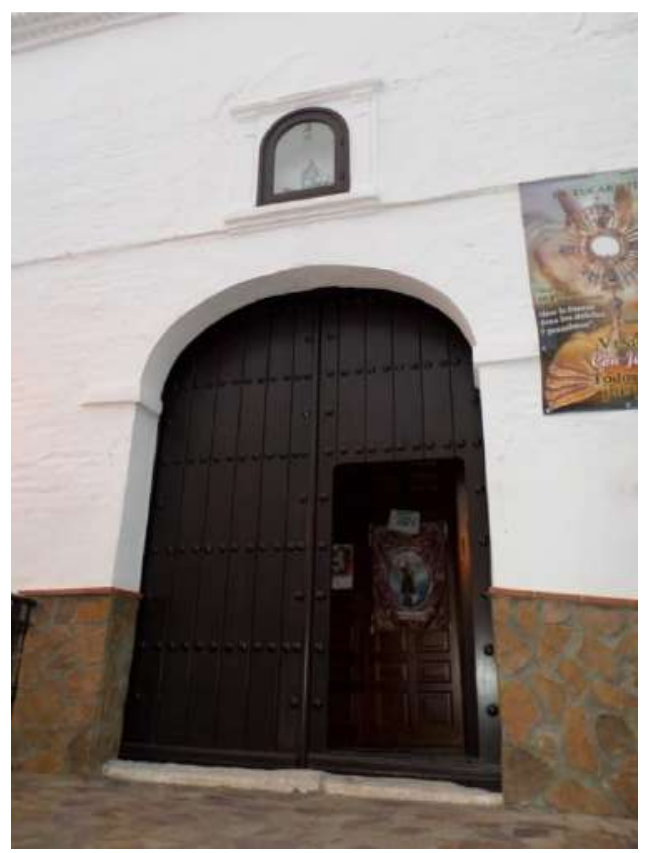

9) Portada Este.

Con respecto al interior, hemos de comentar que los muros de la iglesia son gruesos y cumplen la función de cerramiento y sustento del peso de los elementos superiores, además de que dan gran sensación de solidez. La nave principal hoy está cubierta por un techo de hormigón, pero como hemos comentado al principio, ésta tenía una armadura de la que no tenemos ninguna descripción. ${ }^{154}$ El coro está sostenido por un alfarje con tres jácenas sin decoración y muy simples, teniendo las dos jácenas de los extremos canes lobulados; a su vez presenta diecisiete jaldetas sin decoración donde se

${ }^{154}$ MARTÍN GARCÍA, Mariano. "Iglesias Fortificadas.... Op. cit., pág. 719. 
colocan las tablazones que tampoco presentan decoración ninguna; destacar el refuerzo que tiene para sostener el peso del coro. Las naves laterales están cubiertas por un techo plano; mientras que la capilla mayor tiene una bóveda de crucería con los arcos pintados al fresco, una decoración de piña en la intersección en oro, y en los plementos, decoración floral en el mismo color.

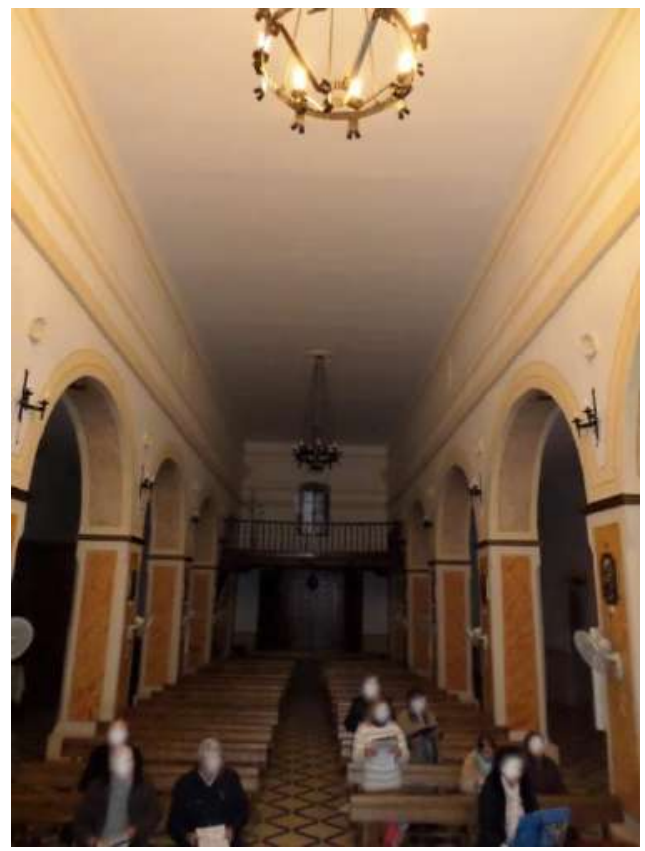

10) Nave central de la iglesia con techo de hormigón.

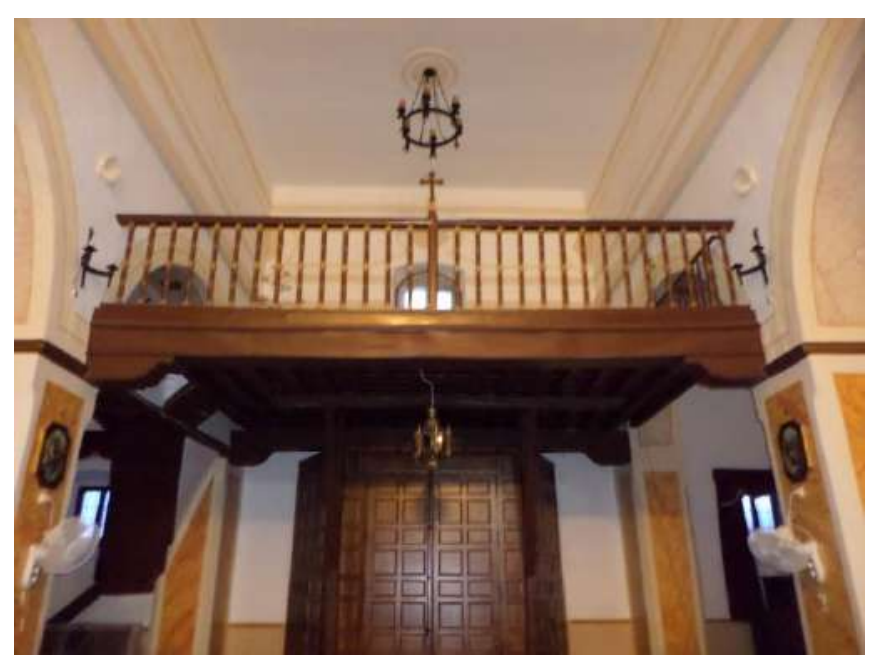

11) Alfarje. 


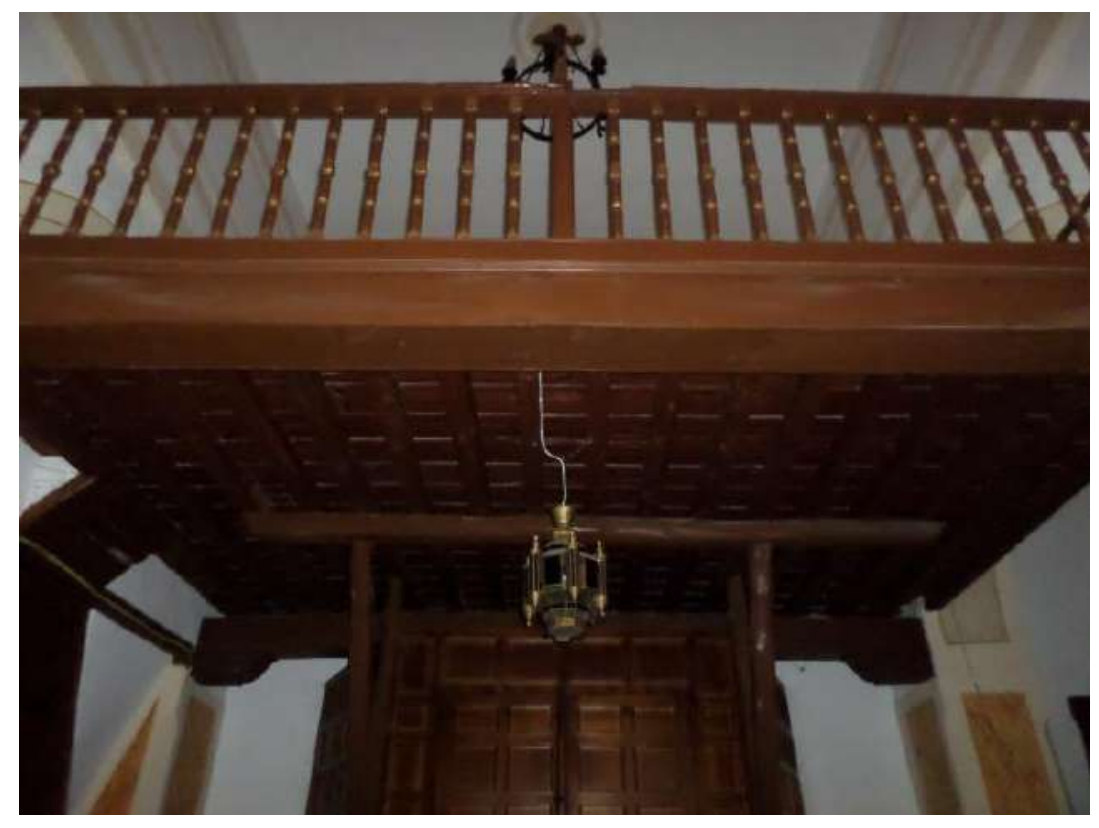

12) Detalle del alfarje.

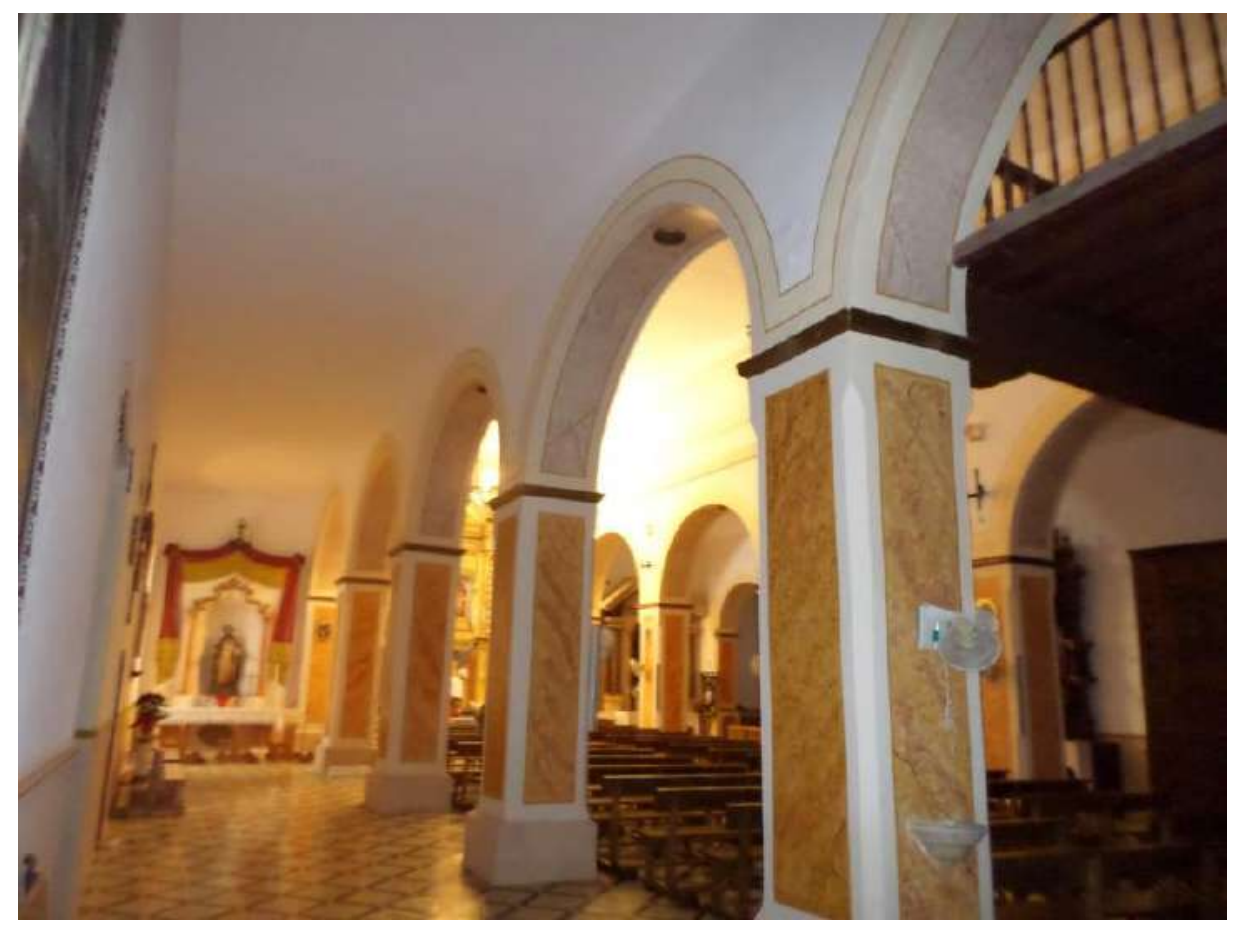

13) Nave lateral izquierda. 


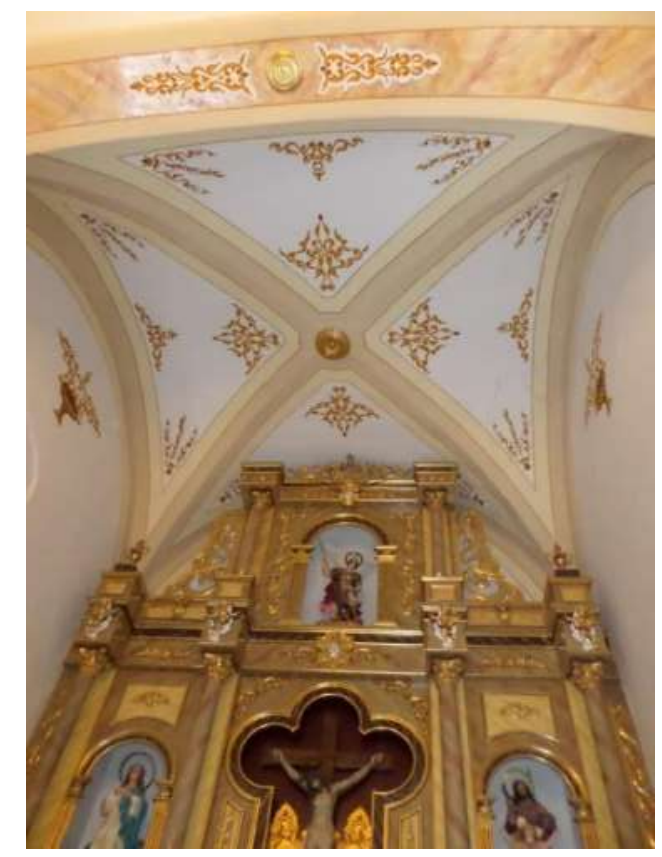

14) Bóveda de crucería de la capilla mayor.

Por último, pasamos a describir la torre, que en siglos anteriores y según la documentación tendría almenas. La torre presenta tres cuerpos que se corresponden con las tres plantas internas ${ }^{155}$ y se sitúa en el NE de la iglesia, construida en cintas de yeso y ladrillo y cajones de mampostería. Un arco de medio punto con una campana aparece en cada uno de sus cuatro lados de su cuerpo superior y se cierra con un tejado a cuatro aguas.

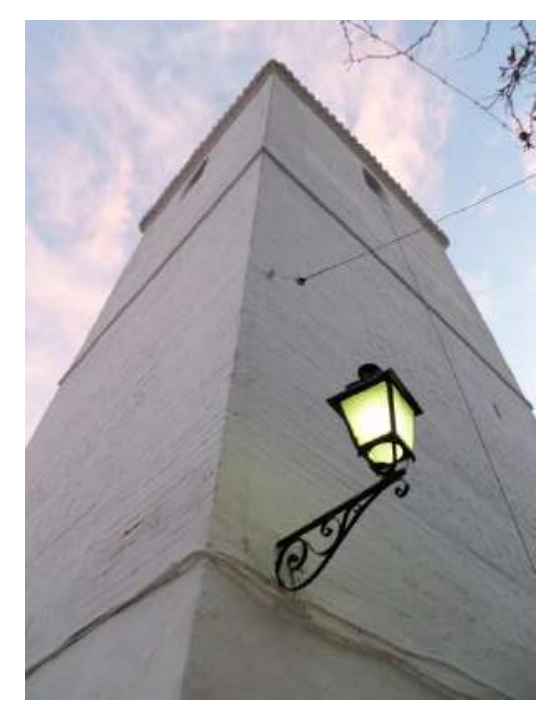

15) Torre.

\footnotetext{
${ }^{155}$ Algo que parece indicar que sería una iglesia-fortaleza, o que querrían que proyectara una imagen de baluarte de cara al mar ante el ataque de los piratas.

- MARTÍN GARCÍA, Mariano. “Iglesias Fortificadas.... Op. cit., pág. 719.
} 


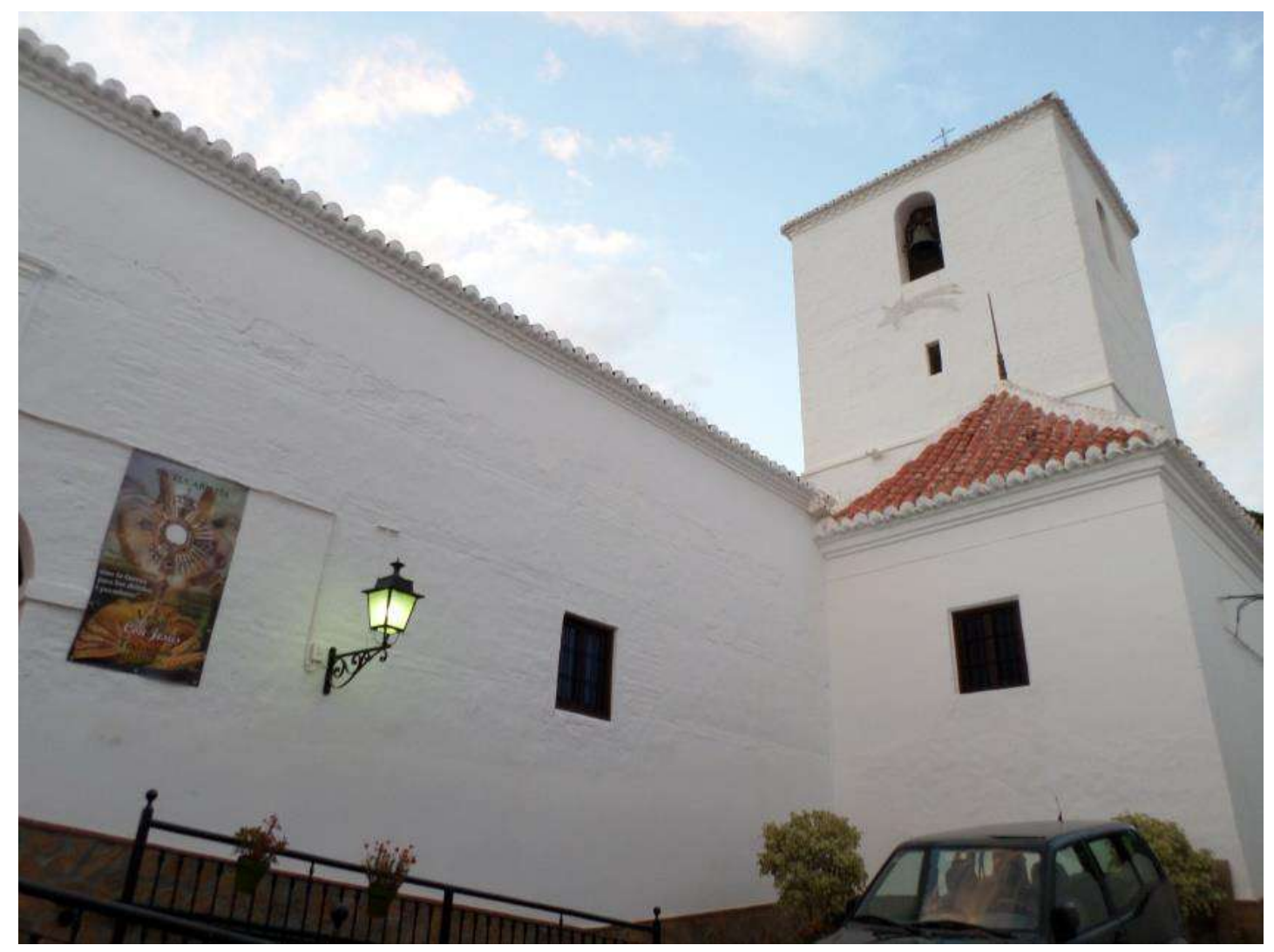

16) Vista de la torre

De la iglesia descrita, la estructura espacial. Del inmenso exterior, las cintas de ladrillo y yeso y cajones de mamposterías y especialmente las portadas Sur y Este, y la torre. Del interior, la parte mudéjar es la antigua armadura de la nave central que desapareció en la Guerra Civil junto con el oscuro alfarje que sostiene el coro.

\subsection{Iglesia Parroquial de la Inmaculada Concepción de Rubite.}

La Iglesia Parroquial de la Inmaculada Concepción de Rubite es un templo levantado en el s. XVII y que tuvo sus reformas estructurales entre los años 1807 y 1815 a manos del maestro de obras Nicolás de Funes. ${ }^{156}$ Los principales materiales de construcción que se emplearon en su edificación fueron la piedra, el ladrillo, el yeso y la madera, algunos de los cuales aparecen revocados hoy en día en su fachada principal y en la torre, no siendo este caso antes de la Guerra Civil española como nos cuentas sus vecinos.

${ }^{156}$ VV.AA. Guía artística de Granada y su.... Op. cit., pág., 199. 


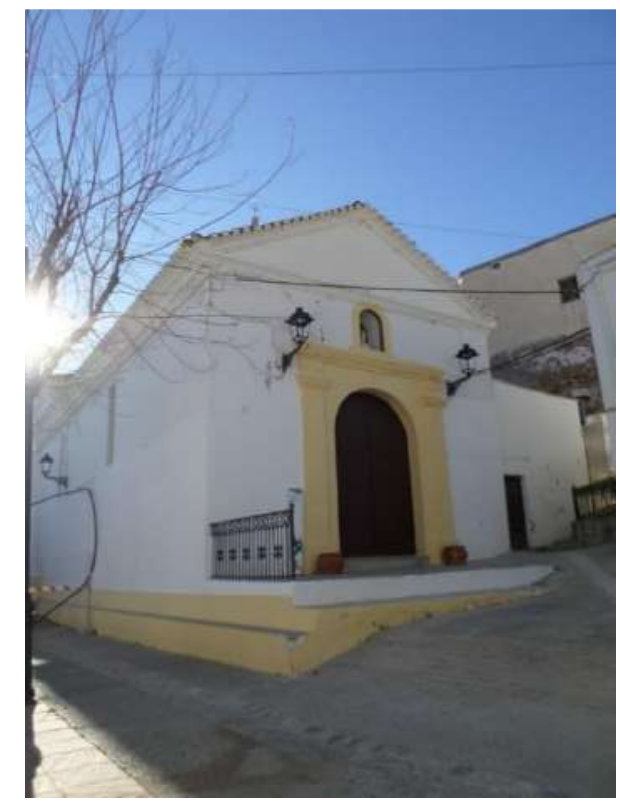

1) Iglesia de la Inmaculada Concepción de Rubite.

La iglesia tiene una única nave rectangular con capilla mayor diferenciada. Por medio de la nave de la iglesia se accede a esta capilla mayor a través de un arco toral ${ }^{157}$ de medio punto sostenido por pilares de orden toscano. El arco y los pilares presentan una franja en color dorado. La capilla mayor es cuadrada y por ella se accede a la sacristía.

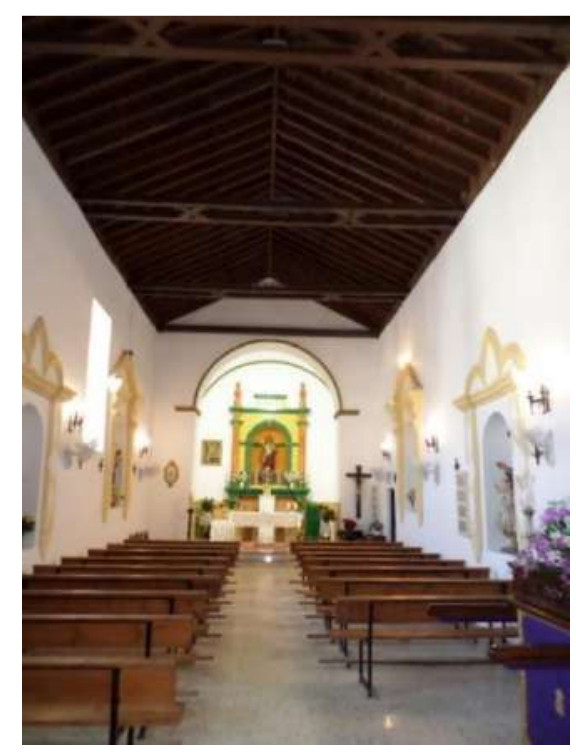

2) Nave de la iglesia.

${ }^{157}$ Este esquema de nave única rectangular y capilla mayor diferenciada separada por un arco toral responde a un tipo de Iglesia Mudéjar según el estudio realizado por Don Rafael López Guzmán e Ignacio Henares Cuéllar en:

- $\quad$ HENARES CUÉLLAR, Ignacio; LÓPEZ GUZMAN, Rafael. Arquitectura Mudéjar.... Op. cit. 


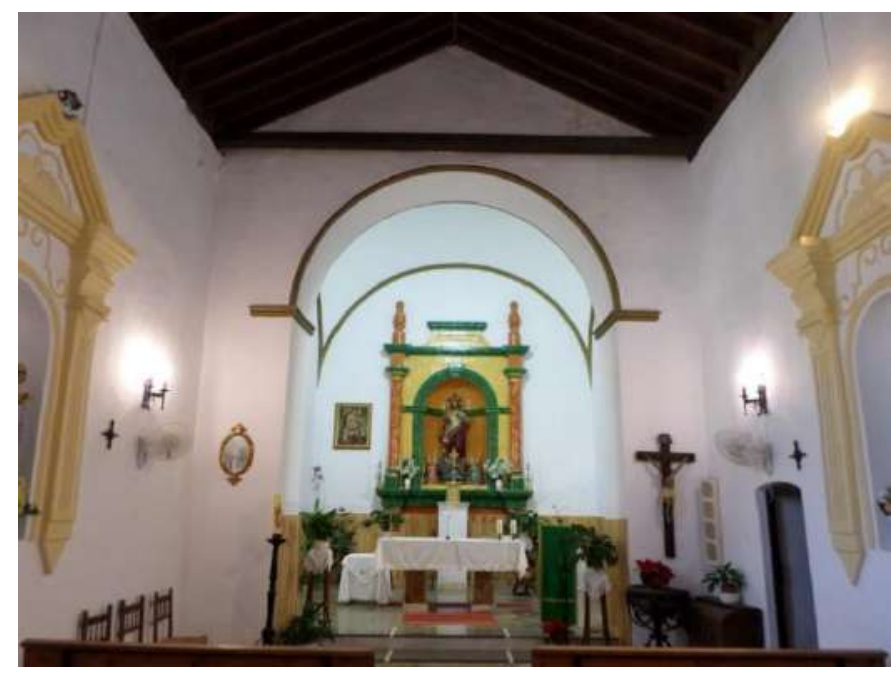

3) Arco toral de acceso a la capilla mayor.

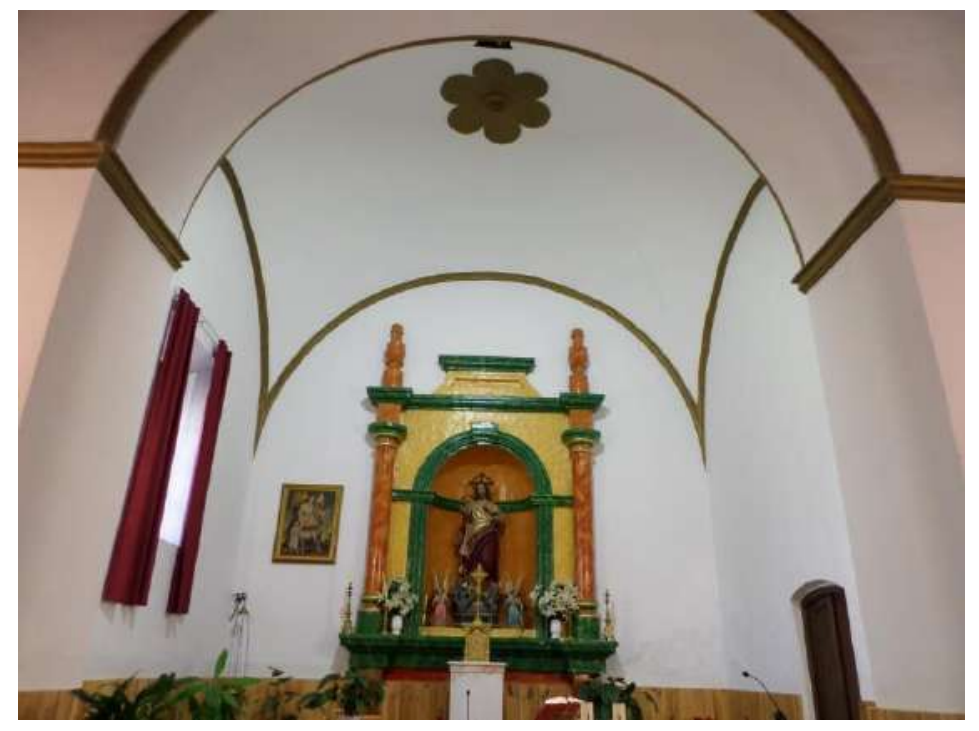

4) Capilla mayor.

En el exterior, hemos de indicar que la mayor parte de la iglesia tiene un revoco contemporáneo, habiendo perdido con ella las cintas de yeso y ladrillo y cajones de mampostería, ${ }^{158}$ aunque no es el caso de la fachada principal. Rodeando todo el templo hay una cornisa que contiene canecillos. En la fachada principal vemos una puerta enmarcada por un arco de medio punto rodeada por pilastras dóricas que sostienen una

${ }^{158}$ Cuando realicé el trabajo de campo pude percibir la configuración y reconstrucción contemporánea de los muros exteriores, aunque no sabemos la fecha exacta de dicha obra, pero como describimos en el texto, no se perciben los materiales propios del mudéjar. 
cornisa, y encima de todo, una hornacina con forma de arco de medio punto, todo pintado de color amarillo. ${ }^{159}$ Esta fachada está coronada por un frontón triangular.

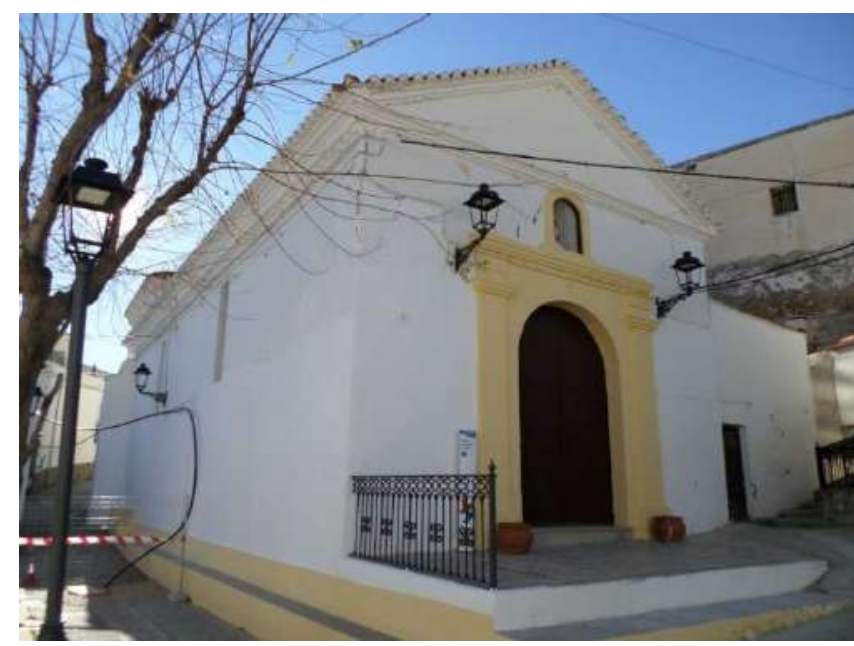

5) Exterior del templo.

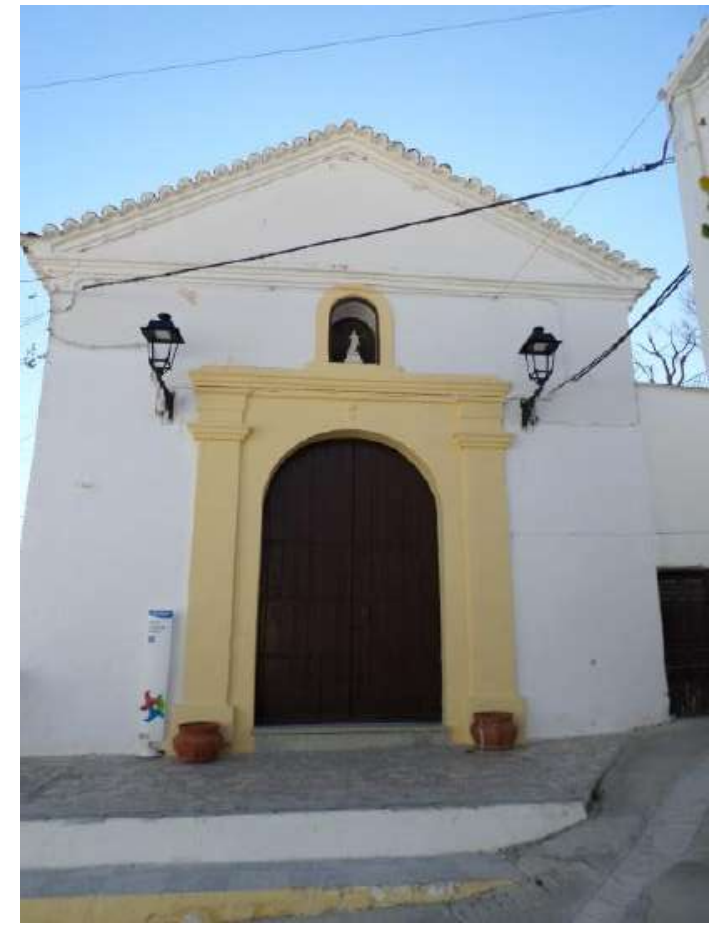

6) Fachada principal del templo.

Pasando al interior, hay que comentar que los muros de la iglesia son gruesos y cumplen la función de cerramiento y sustento del peso de los elementos superiores, además de que dan gran sensación de solidez. La nave única y principal presenta dos vanos adintelados que iluminan el interior en su muro lateral izquierdo, Además, esta

\footnotetext{
${ }^{159}$ Constatamos que todo está realizado en ladrillo porque hemos podido comprobar en el trabajo de campo como debajo del revoco el ladrillo es el material predominante.
} 
nave está cubierta por una armadura caracterizada por ser de par e hilera con tirantes pareados que contienen decoración de chillas en cada uno de dichos tirantes, y éstos no están apoyados en ningún tipo de can, sino directamente en el muro. La armadura tampoco tiene cuadrales ni almizate ni ningún tipo de decoración en los pares, siendo así una armadura llana. Armadura que es una reconstrucción posterior a la Guerra Civil española ya que la primitiva desapareció en dicha contienda. ${ }^{160}$ La capilla mayor está cubierta por una bóveda vaída en cuyo centro se encuentra una decoración floral de color dorada y rodeando la bóveda una franja del mismo color que marca su contorno.

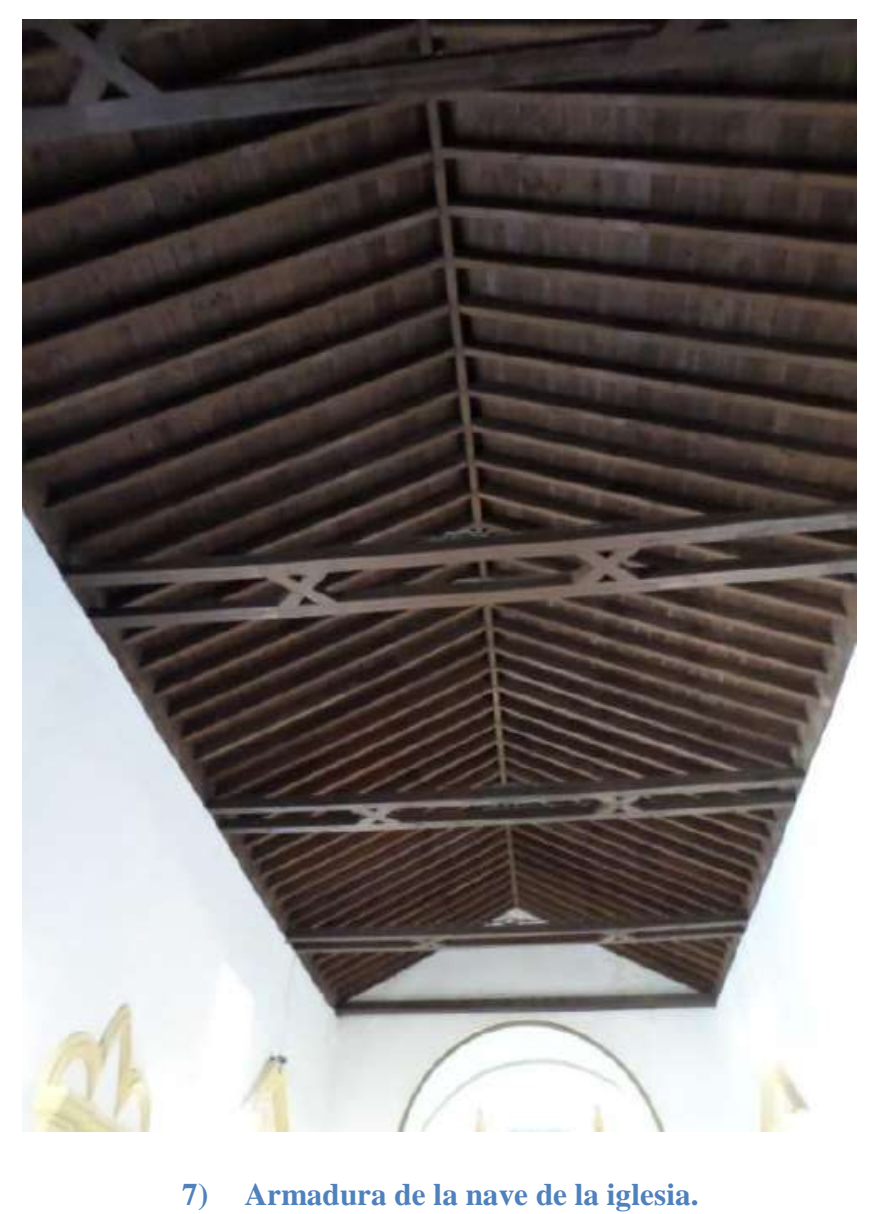

${ }^{160}$ VV.AA. Guía artística de Granada y su.... Op. cit., pág. 199. 


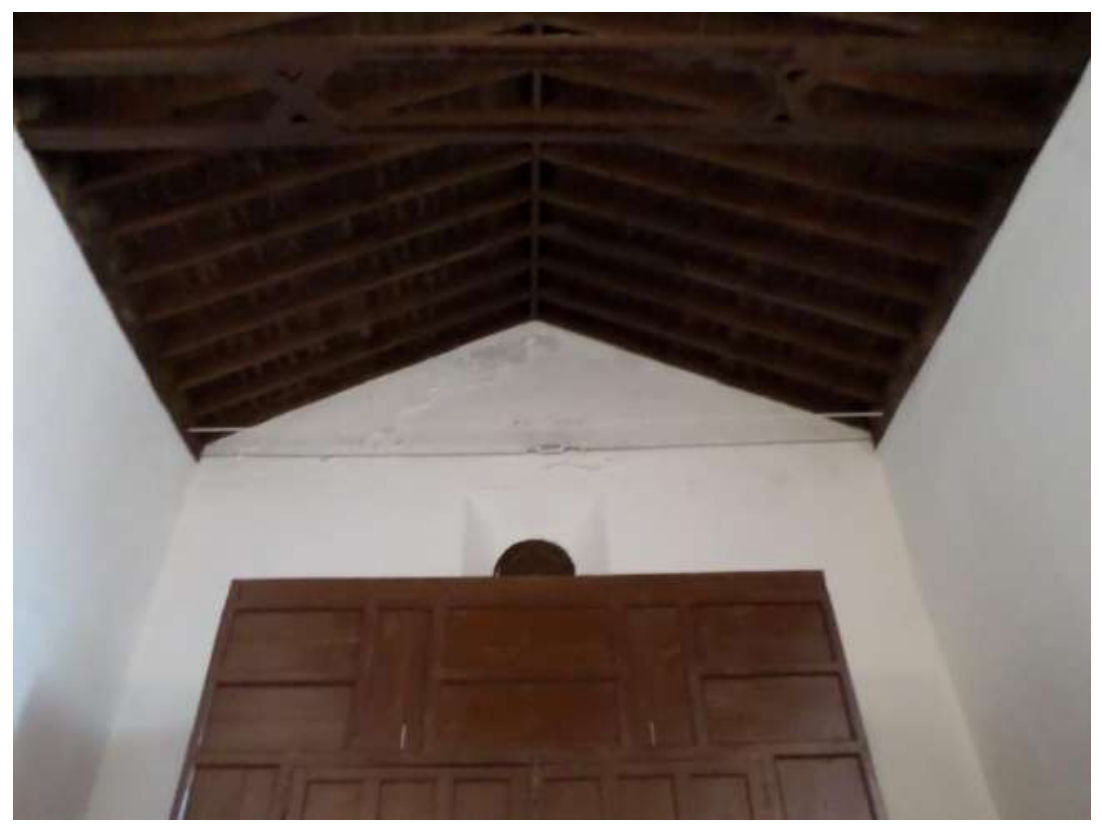

8) Detalle de armadura de la nave.

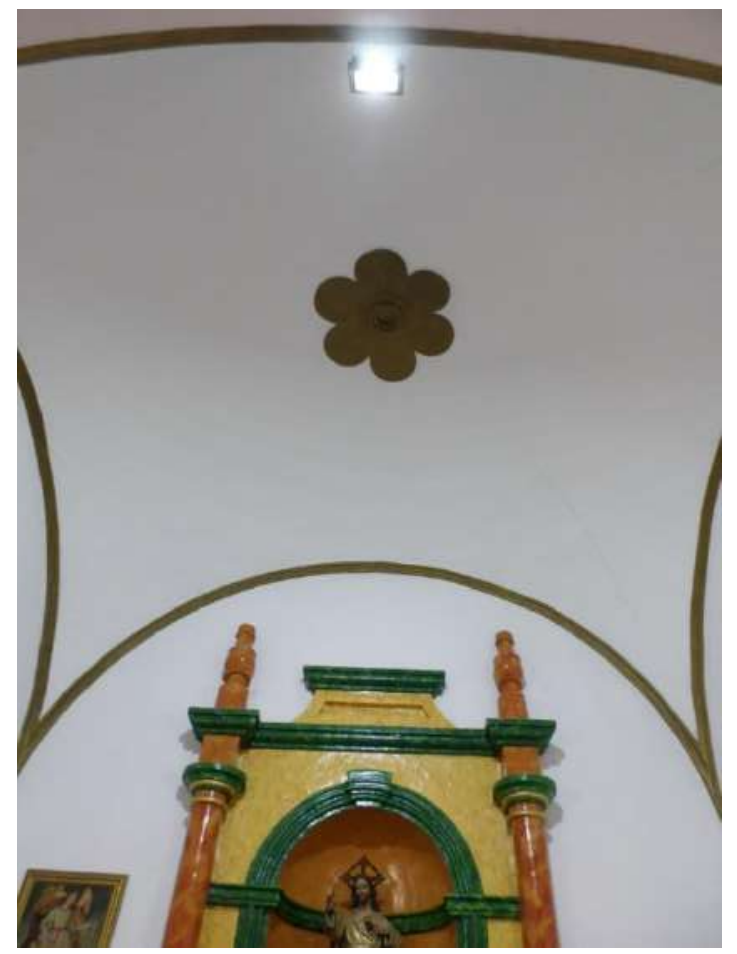

9) Bóveda vaída de la capilla mayor.

Por último, pasamos a comentar la torre que se sitúa en el lado NE de la iglesia. Esta torre tiene tres cuerpos separados por cornisas, correspondiendo el último cuerpo al de las campanas y está coronada por un tejado a cuatro aguas. Los materiales que fueron utilizados en su construcción son las cintas de yeso y ladrillo y cajones de mamposterías, junto con la piedra, aunque aparecen revocados hoy en día como en la fachada principal. 


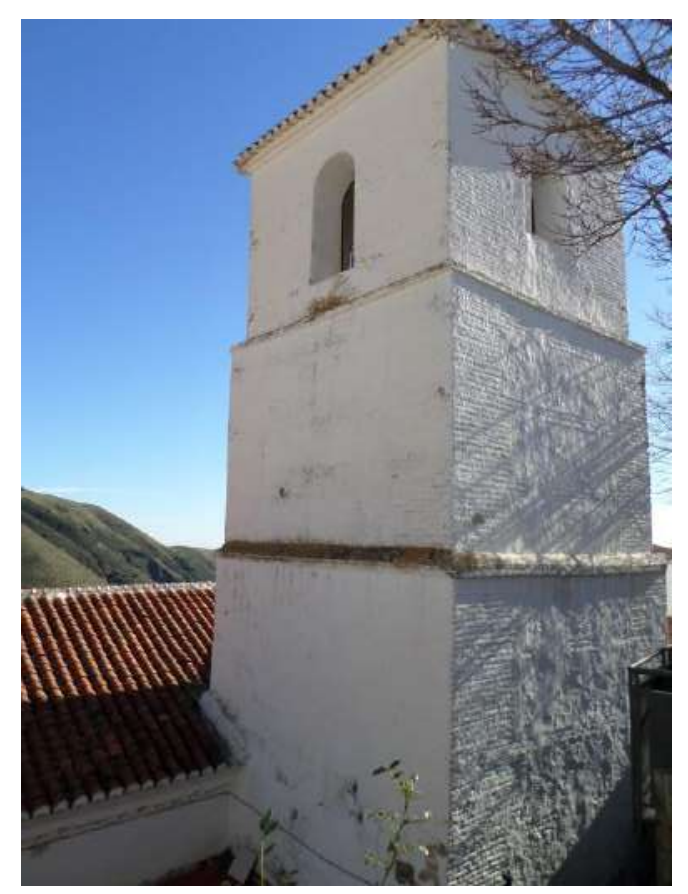

10) Torre.

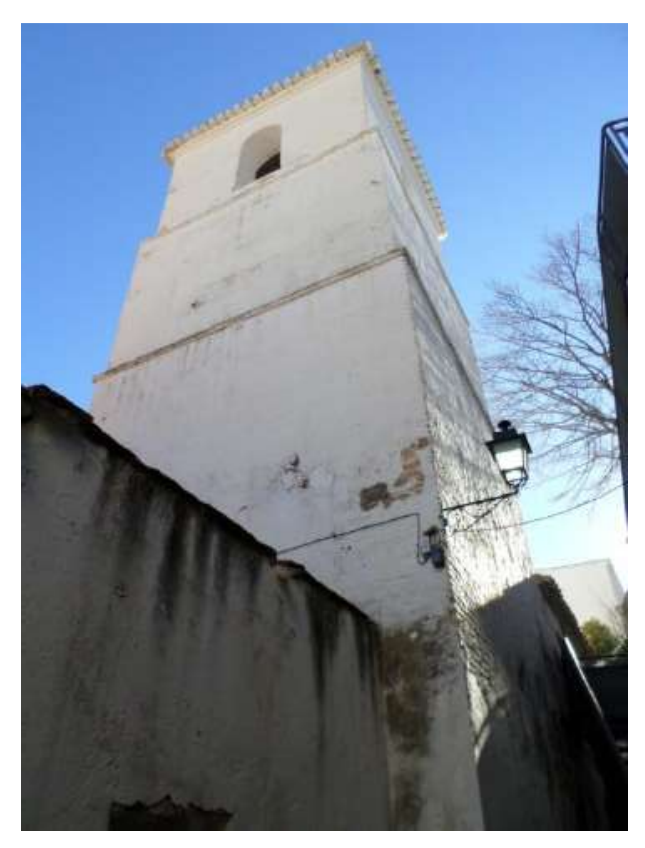

11) Tres cuerpos de la torre. 


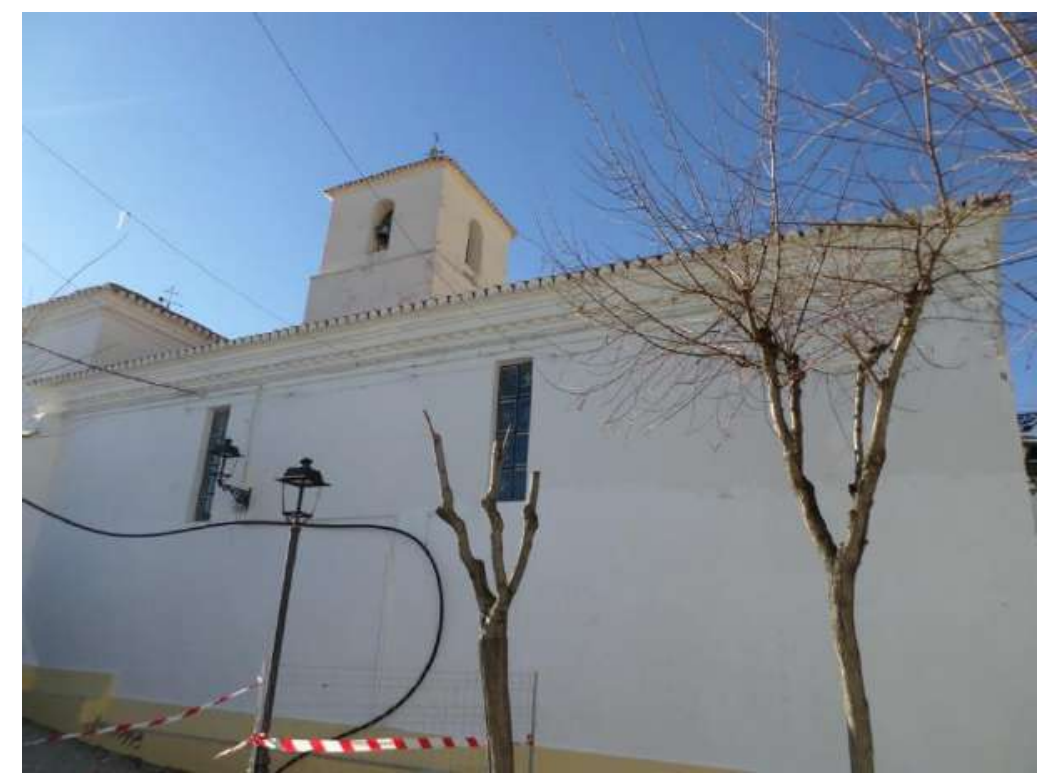

12) Vista de la torre.

De la iglesia descrita, la parte mudéjar sería, en primer lugar, la estructura espacial. Del exterior, aunque está muy transformada, las cintas de yeso y ladrillo y cajones de mampostería, la rica decoración de la fachada principal y la torre. Del interior, la sobria armadura de la nave de la iglesia.

\subsection{Iglesia de Nuestra Señora del Rosario de Polopos.}

La Iglesia de Nuestra Señora del Rosario fue construida entre 1740 y 1752, cuyas obras fueron dirigidas por el maestro Pedro Fernández de Bravo, aunque entre 1782 y 1786 fue ampliada y reparada por Juan de Castellanos. ${ }^{161}$ Los principales materiales de construcción que se emplearon en ella fueron la piedra, el ladrillo, la madera y el yeso, aunque la piedra y el ladrillo están revocados en su fachada principal.

La iglesia tiene una única nave rectangular con capilla mayor diferenciada la que se accede por medio de un arco toral ${ }^{162}$ de medio punto, y presenta coro a los

${ }^{161}$ VV.AA. Guía artística de Granada y su.... Op. cit., pág. 198.

${ }^{162}$ Este tipo de planta de iglesia de nave única rectangular con capilla mayor diferenciada separada por un arco toral responde a un tipo de Iglesia Mudéjar según el estudio realizado por Don Rafael López Guzmán e Ignacio Henares Cuéllar en:

- $\quad$ HENARES CUÉLLAR, Ignacio; LÓPEZ GUZMAN, Rafael. Arquitectura Mudéjar.... Op. cit.

Aunque la capilla mayor fue una ampliación del s. XVIII, como se explica más adelante, por lo que primitivamente tendría una nave única rectangular cubierta por una armadura sin capilla mayor diferenciada, también tipología de iglesia mudéjar de Granada según el estudio realizado por Don Rafael López Guzmán e Ignacio Henares Cuéllar en el mismo documento. 
pies. ${ }^{163}$ Esta capilla mayor, fruto de una ampliación del s. XVIII ${ }^{164}$, es cuadrada y a través de ella se accede a la sacristía.

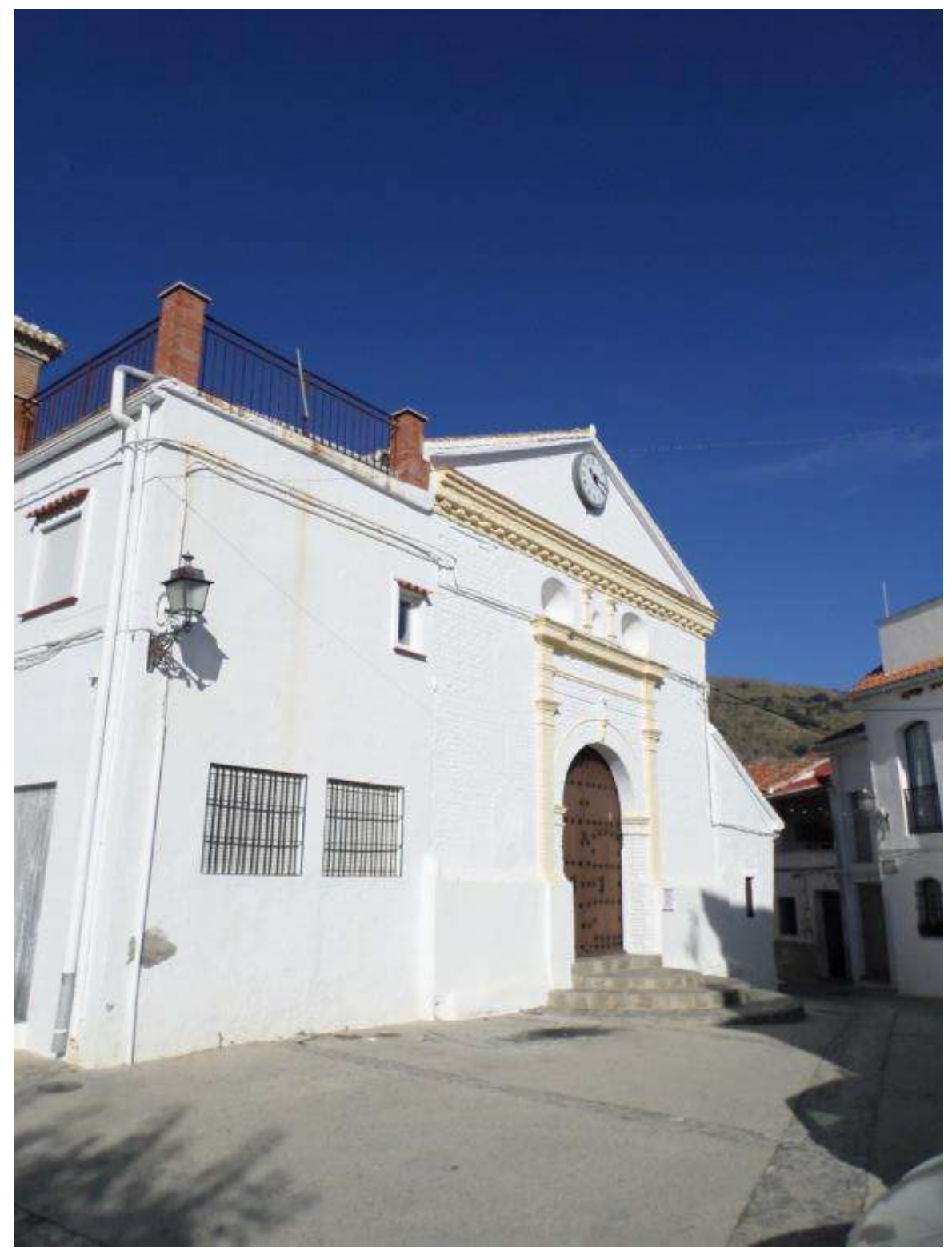

1) Iglesia Nuestra Señora del Rosario.

${ }^{163}$ Este arco toral de medio punto está cubierto en su parte superior actualmente por la cubierta de hormigón de la nave principal que sustituye a la armadura primitiva.

${ }^{164}$ En el plano de la Iglesia tenemos este dato. 


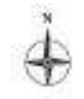

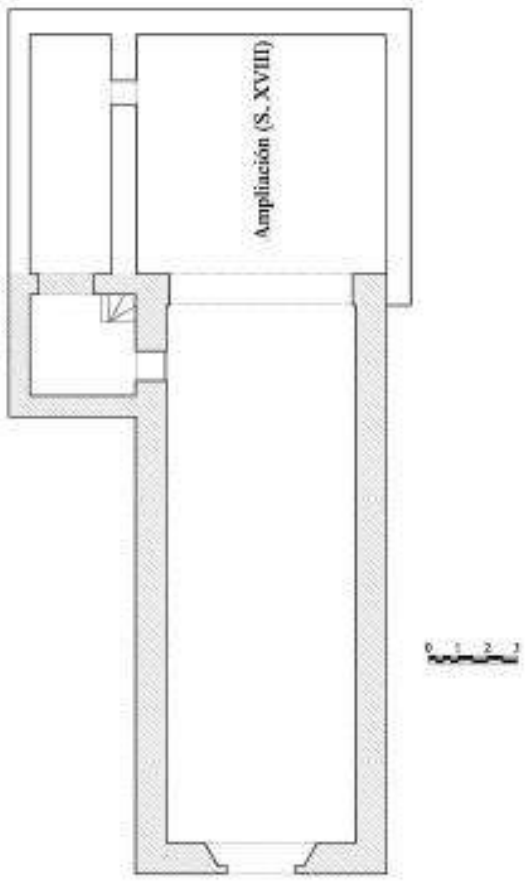

2) Plano de la iglesia. ${ }^{165}$

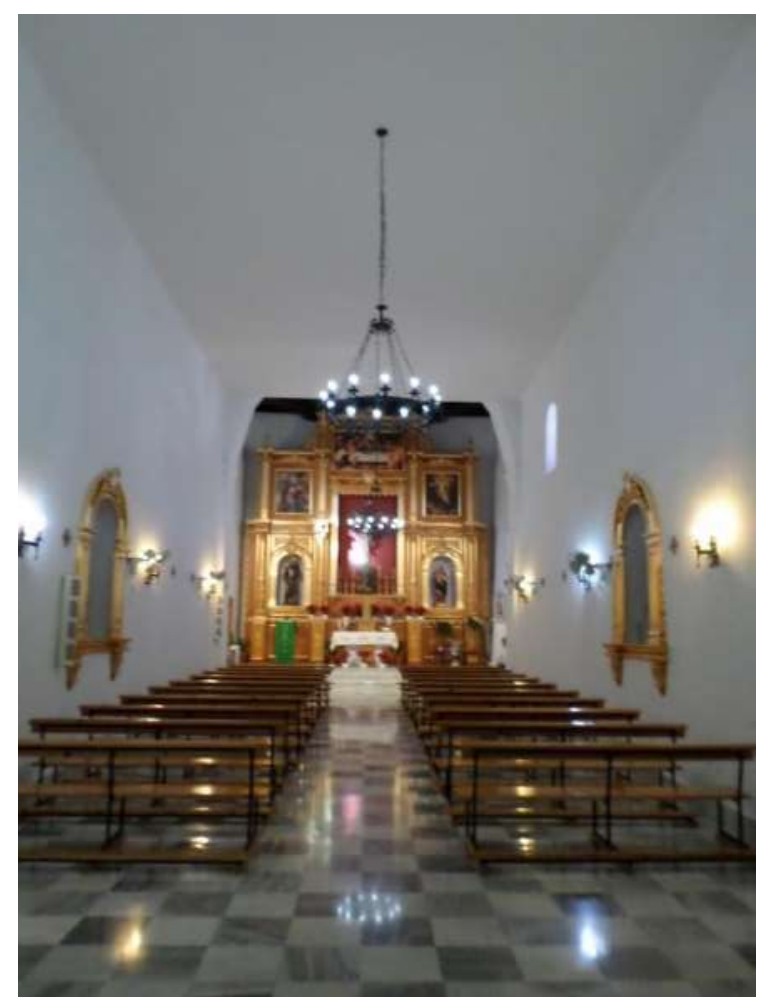

3) Nave de la Iglesia.

${ }^{165}$ MARTÍN GARCÍA, Mariano. "Iglesias Fortificadas.... Op. cit., pág. 732. 


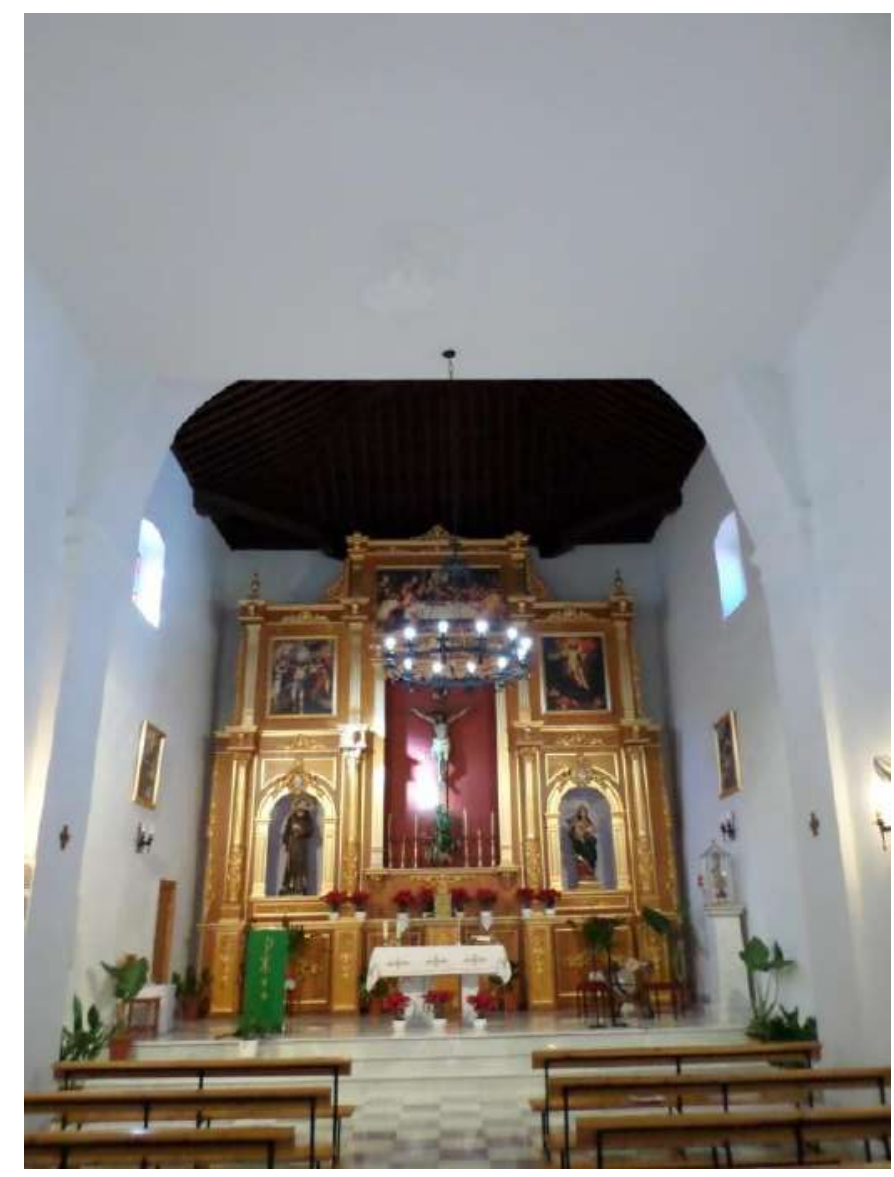

4) Arco toral y capilla mayor.

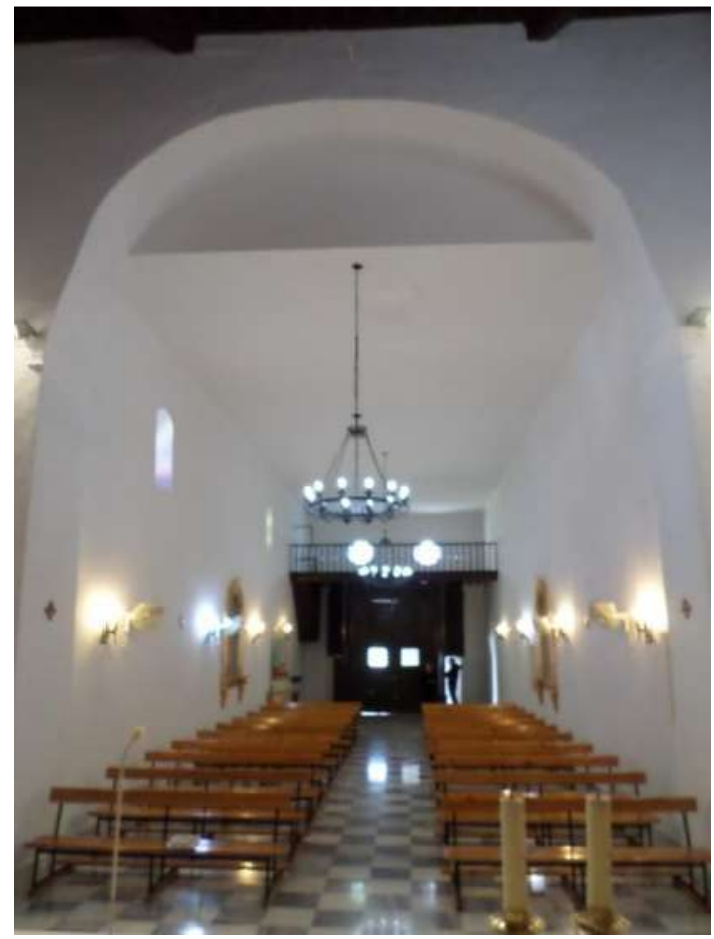

5) Arco toral visto desde la capilla mayor. 


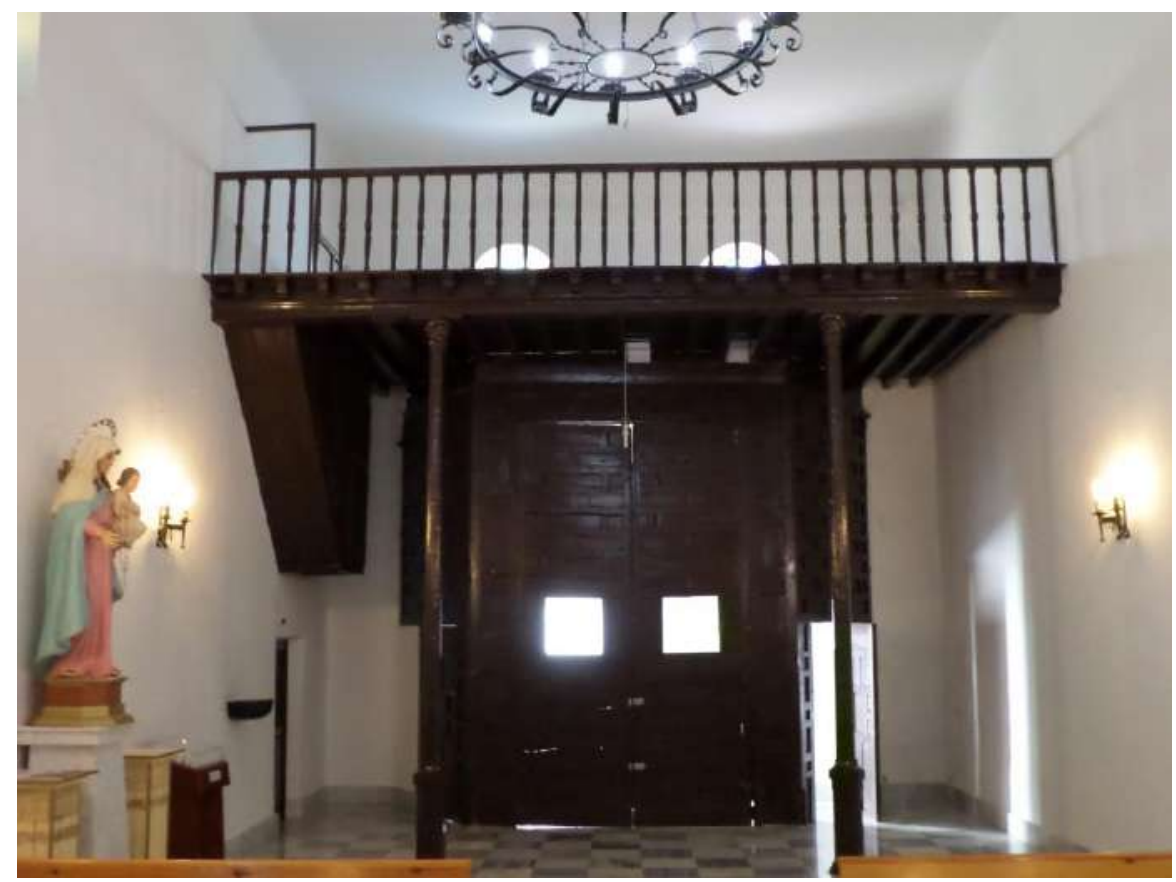

6) Coro.

En el exterior del templo podemos observar varias diferencias fruto del paso del tiempo por el mismo. Así, en primer lugar, nos encontramos con la fachada principal, construida en cintas de yeso y ladrillo y cajones de mampostería, pero hoy en día revocada. ${ }^{166}$. En ella se sitúa la puerta de acceso al templo enmarcada por un arco de medio punto con clave y sostenido por pilares dóricos. Este arco también está enmarcado por dos pilares dóricos que sostienen un arquitrabe y una cornisa sobre la cual se sitúan dos pilastras dóricas de pequeño tamaño rodeadas de dos óculos que iluminan el coro interiormente y justo encima aparece una cornisa con canecillos. La fachada está coronada por un frontón triangular. Los laterales y la cabecera de la iglesia no están revocados por lo que en ellos podemos percibir las cintas de yeso y ladrillo y los cajones de mampostería ${ }^{167}$, aunque parcialmente no se observan muy bien estas zonas porque hay construcciones contemporáneas que rodean la iglesia.

${ }^{166}$ Los vecinos del pueblo nos relatan que antes de la Guerra Civil estaba sin revocar y las cintas de yeso y ladrillo y los cajones de mampostería se percibían.

${ }^{167}$ Parece curioso que en parte se haya respetado el carácter mudéjar de la iglesia y no se haya revocado todo el exterior del propio templo, algo que nos permite conocer cómo sería la iglesia en su esplendor. 


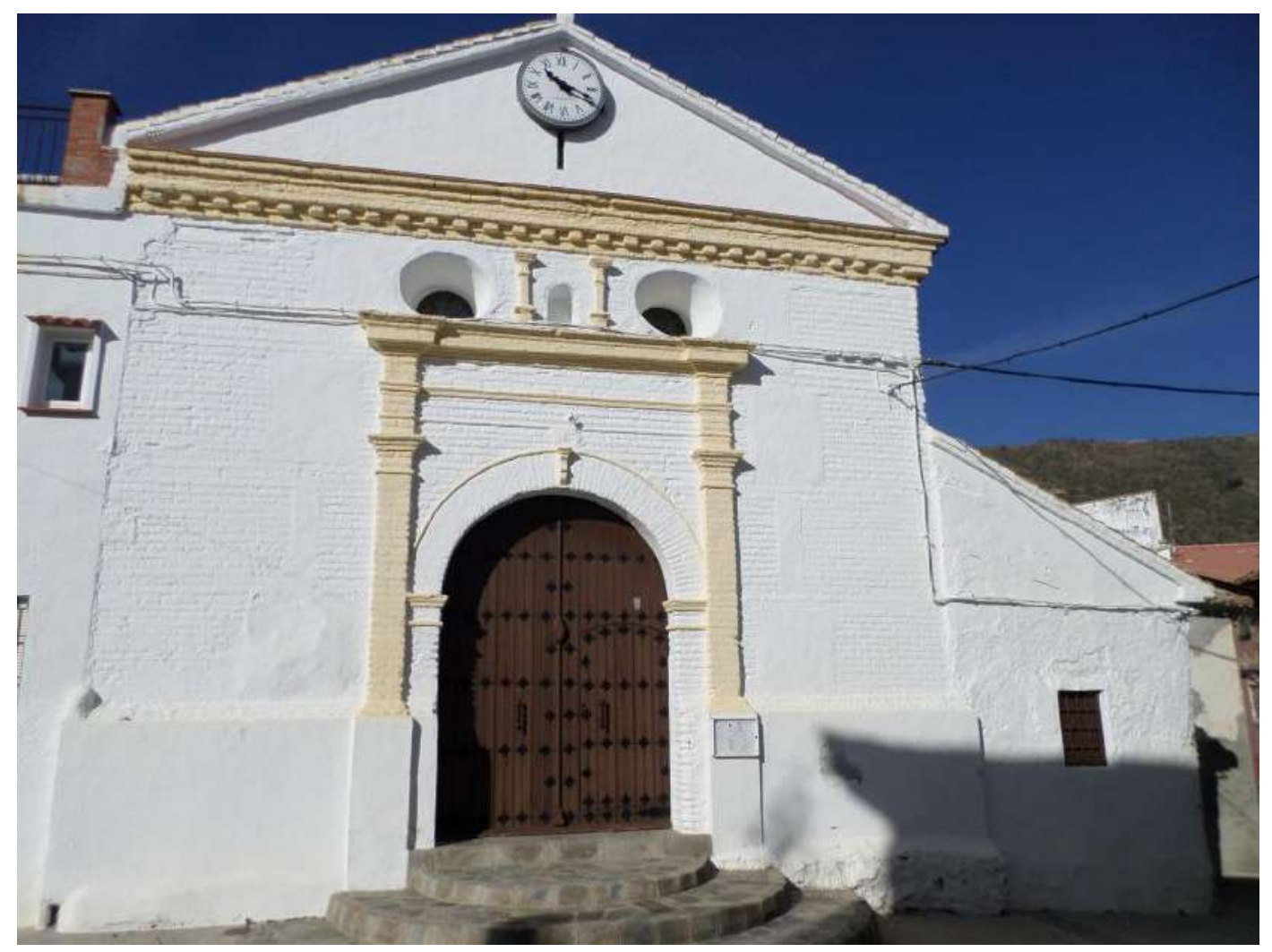

7) Fachada principal.

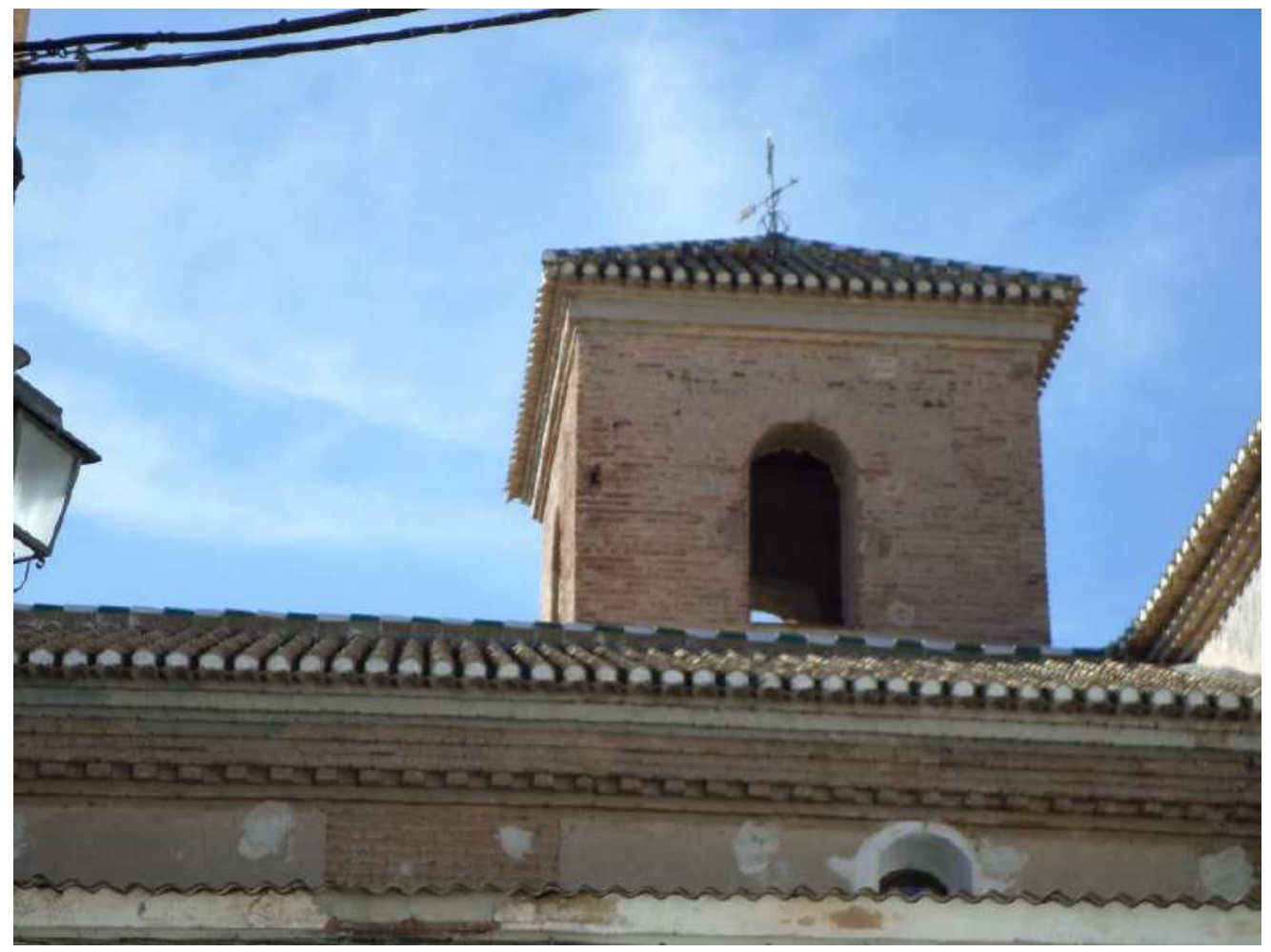

8) Lateral de la iglesia sin revoco.

Pasando a comentar el interior, hay que indicar que los muros cumplen la función de cerramiento del edificio y de descargar del peso de los elementos superior, 
tiene escasos vanos, como los que se encuentran en la capilla mayor tanto en el muro derecho e izquierdo que son de arco escarzano, junto con los dos del muro derecho de la nave principal de arcos de medio punto, que iluminan el interior de la iglesia. La nave principal, como indicamos al principio, está cubierta actualmente por un techo de hormigón que sustituye a la primitiva armadura de par e hilera ${ }^{168}$ que desapareció en la Guerra Civil española. ${ }^{169}$ La capilla mayor está cubierta por una armadura de loma bordón, con cuadrales que tienen canes lobulados, y almizate, pero sin decoración. Los pares tampoco tienen decoración, por lo que la armadura es llana. A su vez, el coro está sostenido por un alfarje compuesto por una única jácena, sin canes y veinte jaldetas que sobresalen por la jácena y sobre las que se colocan las tablazones. El alfarje está sostenido por dos columnas de manera. Además, tiene el hueco de las escaleras de acceso al coro en su parte derecha. Al igual que la armadura de la capilla mayor, tampoco presenta decoración.

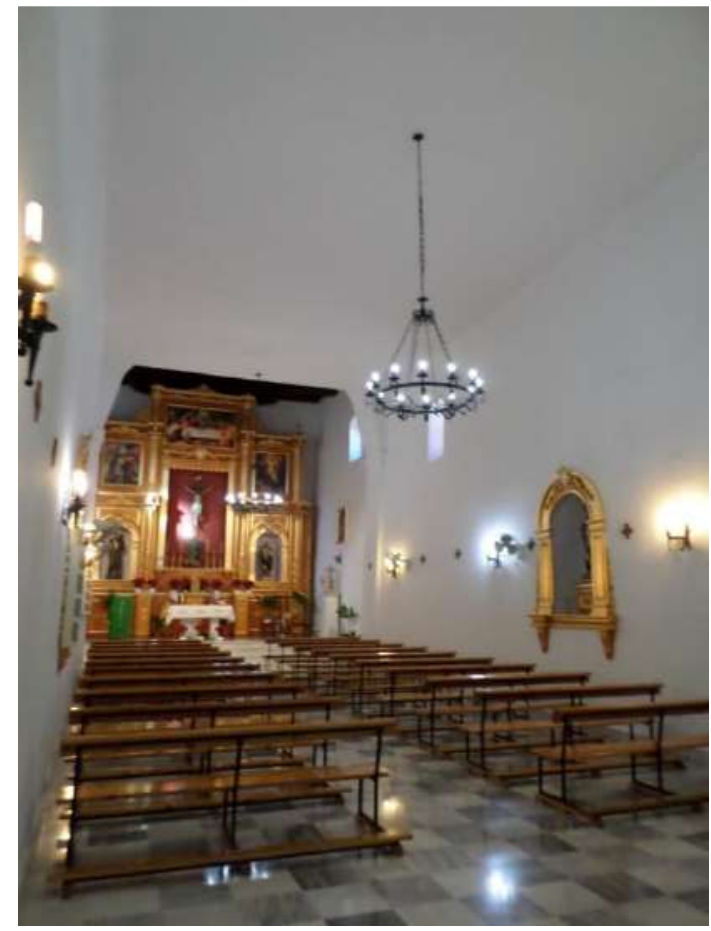

9) Nave de la iglesia con techo plano de hormigón que sustituye a la armadura primitiva.

168 No tenemos más detalles de la armadura.

169 VV.AA. Guía artística de Granada y su.... Op. cit., pág., 198. 


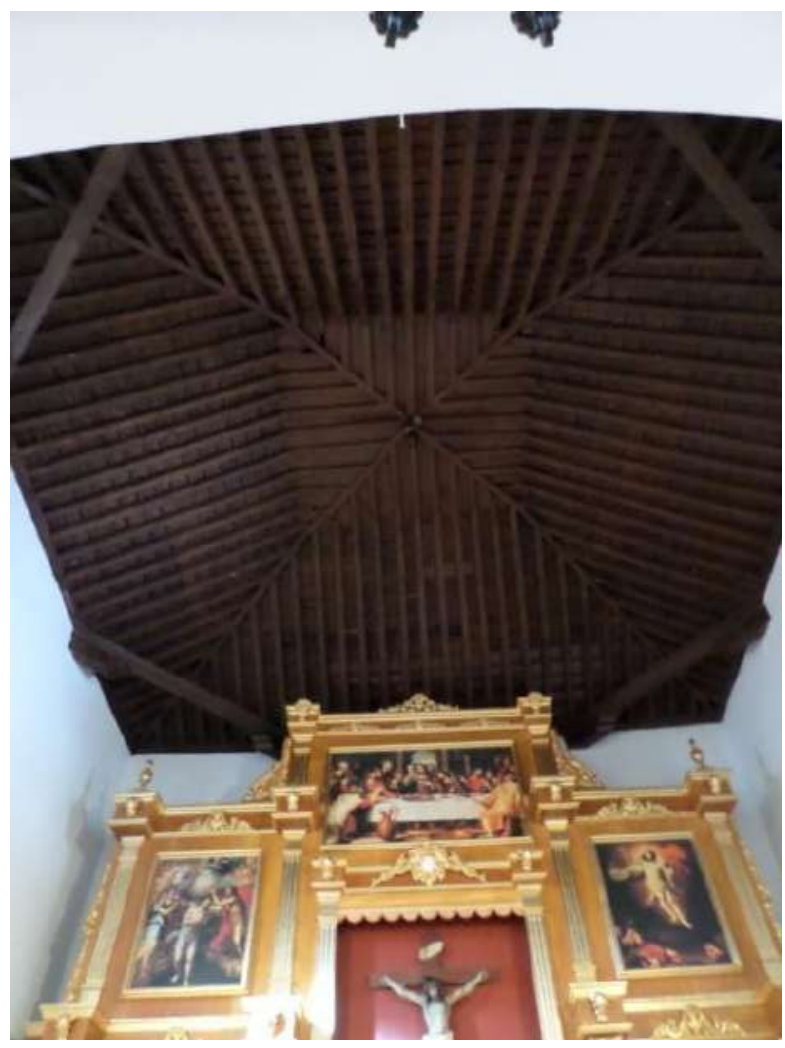

10) Armadura de la capilla mayor.

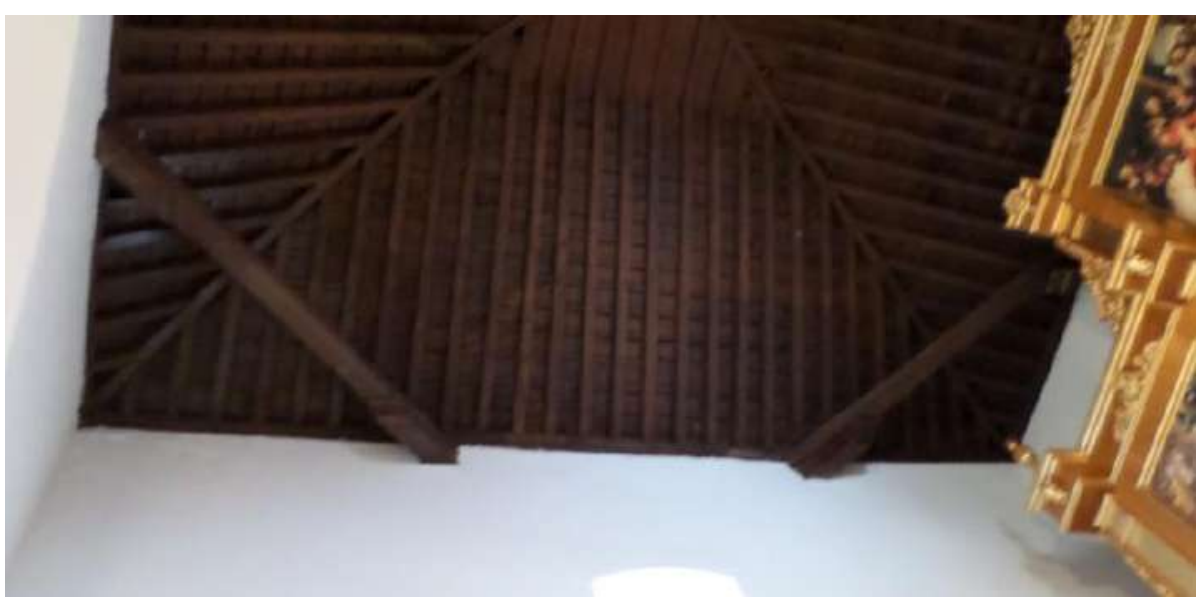

11) Detalle de los cuadrales de la armadura de la capilla mayor.

Por último, describimos la torre que se encuentra situada en el lado Oeste. La torre está construida en cintas de ladrillo y yeso y cajones de mampostería, y solo está revocada en su parte inferior, algo que nos permite ver el original de esta y los materiales con que ha sido hecha, observando el esplendor primero. La torre presenta un arco de medio punto para las campanas en sus cuatro lados. 


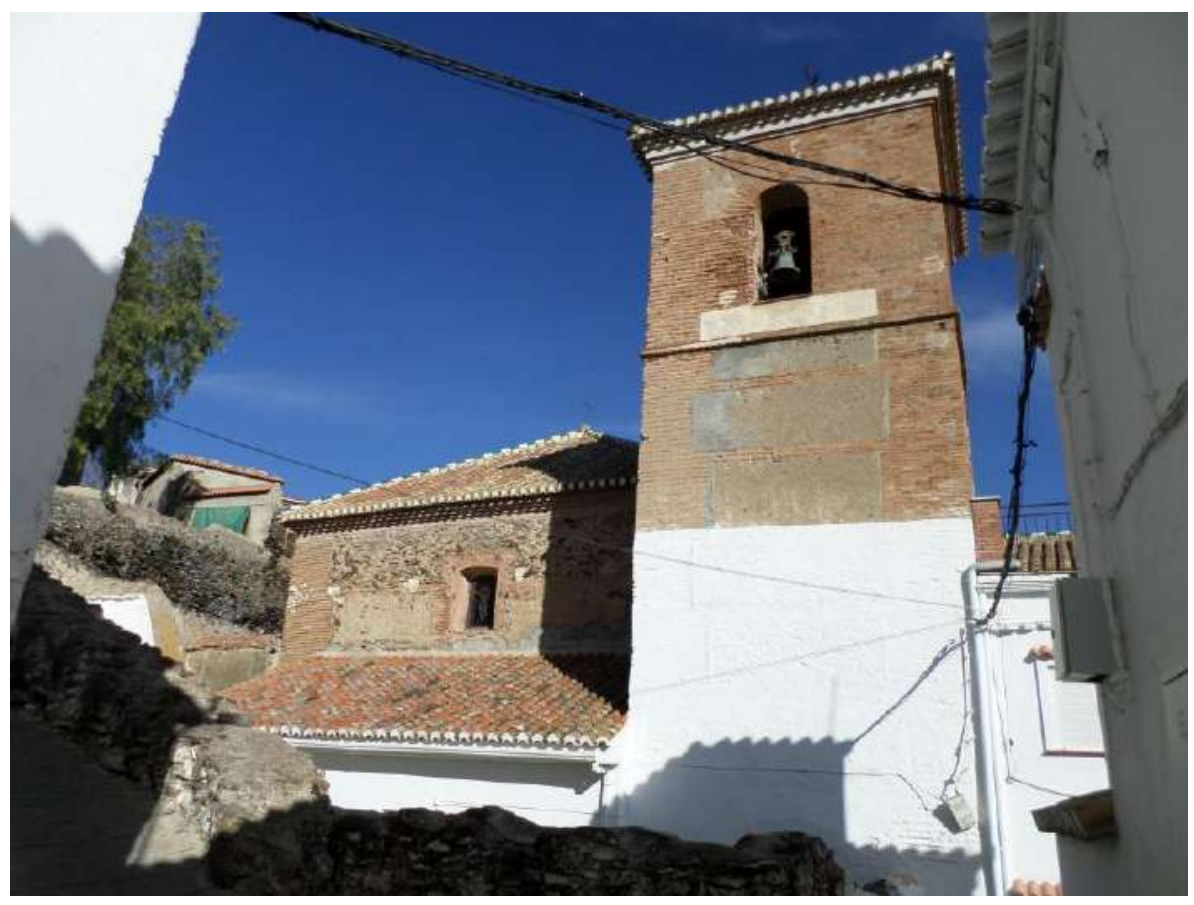

12) Vista de la torre.

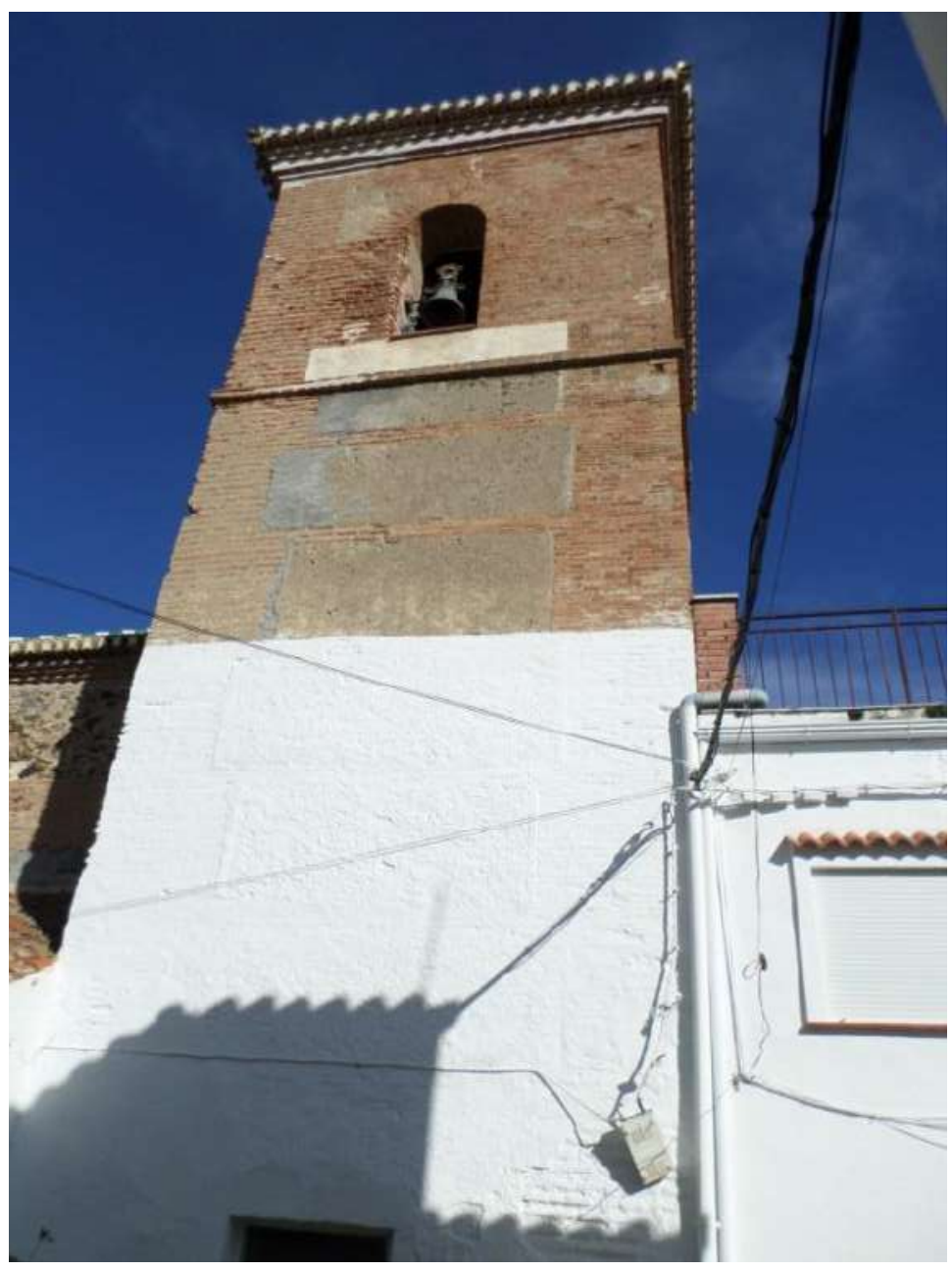

13) Torre. 
De la iglesia descrita, la parte mudéjar sería, en primer lugar, la estructura espacial. Del exterior, las cintas de ladrillo y yeso y cajones de mamposterías, la gran fachada principal con su predominante decoración, sin contar el frontón triangular, y la torre. Del interior, la antigua armadura de la nave de la iglesia desaparecida en la Guerra Civil, la actual y gran armadura de la capilla mayor, junto con el alfarje que sostiene el coro.

\subsection{Iglesia Parroquial de San Cayetano de Sorvilán.}

La Iglesia Parroquial de San Cayetano es un templo que se construyó entre 1667 y 1670 y cuyas obras fueron dirigidas por el albañil Diego González y la carpintería realizada por Francisco González. ${ }^{170}$ Los principales materiales de construcción de la iglesia son la piedra, el ladrillo, la madera y el yeso. La piedra y el ladrillo están revocados en su fachada principal hoy en día.

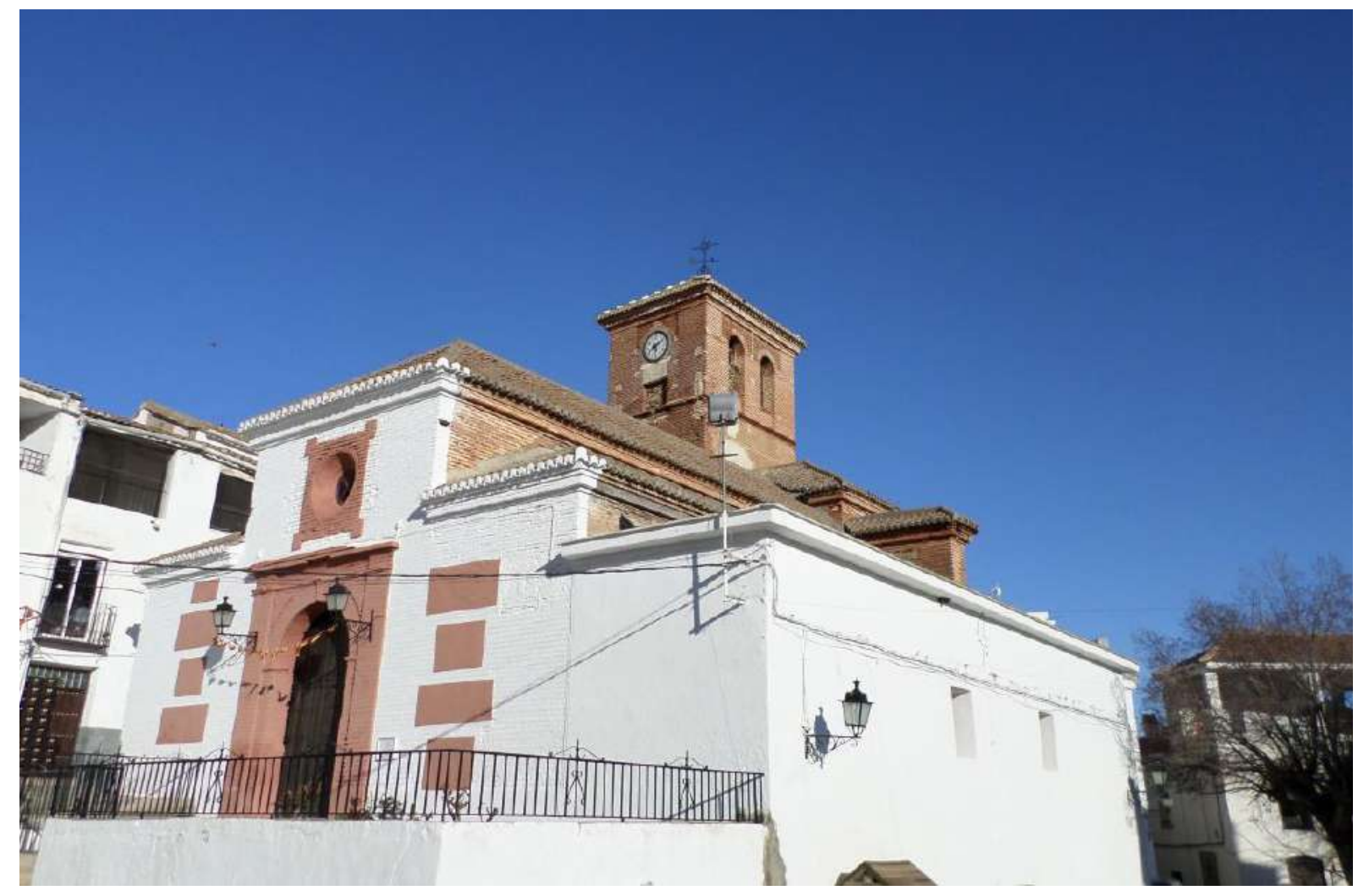

1) Iglesia Parroquial de San Cayetano.

La iglesia tiene tres naves separadas por dos arcos de medio punto enmarcados por un alfiz pintado de color marrón y capilla mayor diferenciada. ${ }^{171}$ Junto a la nave

${ }^{170}$ VV.AA. Guía artística de Granada y su.... Op. cit., pág., 200.

${ }^{171}$ Este tipo de planta de tres naves separadas por arcos y capilla mayor diferenciada, en cuya nave central hay una armadura, según el esquema de iglesia que observamos, y en las laterales armaduras 
lateral derecha se sitúa otra nave fruto de una ampliación del s. XX a la que se accede por medio de dos arcos escarzanos. ${ }^{172}$ La nave central es más alta con respecto a las laterales, pero de igual anchura que ellas. Accedemos a la capilla mayor, que es cuadrada y por la que se da paso a la sacristía, a través de la nave central por medio de un arco toral de medio punto pintado de color marrón.

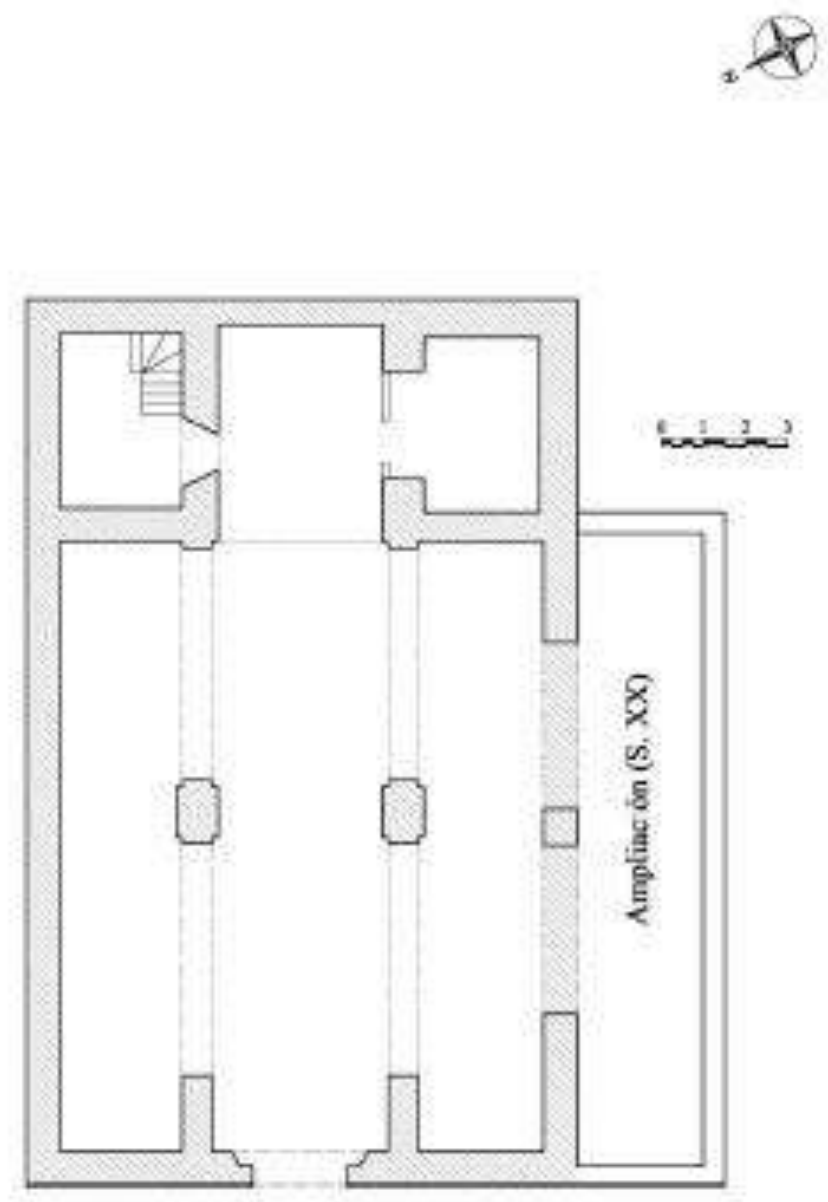

2) Plano de la Iglesia. ${ }^{173}$

de colgadizo, con una capilla mayor cubierta armadura, como bien se describe más adelante, respondiendo en cierta medida a las tipologías de planta de iglesias mudéjares de Granada según el estudio realizado por Don Rafael López Guzmán:

- $\quad$ LÓPEZ GUZMÁN, Rafael. Arquitectura...Op. cit., pág.396.

${ }^{172}$ Sabemos que es una ampliación del s. XX por el plano de la iglesia del que disponemos y por el testimonio de los vecinos del pueblo.

${ }^{173}$ MARTÍN GARCÍA, Mariano. "Iglesias Fortificadas.... Op. cit., pág. 732. 


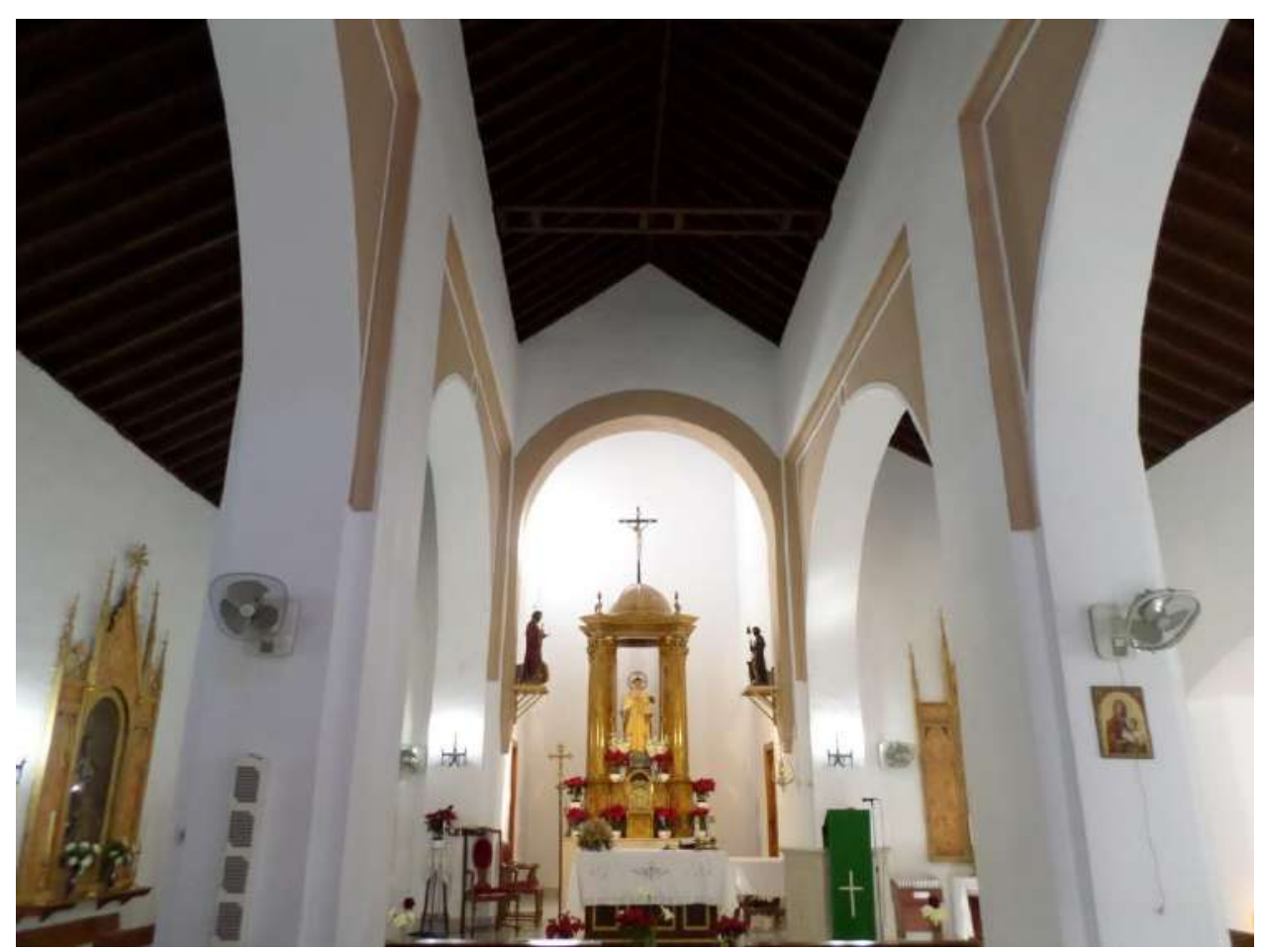

3) Las tres naves de la iglesia.

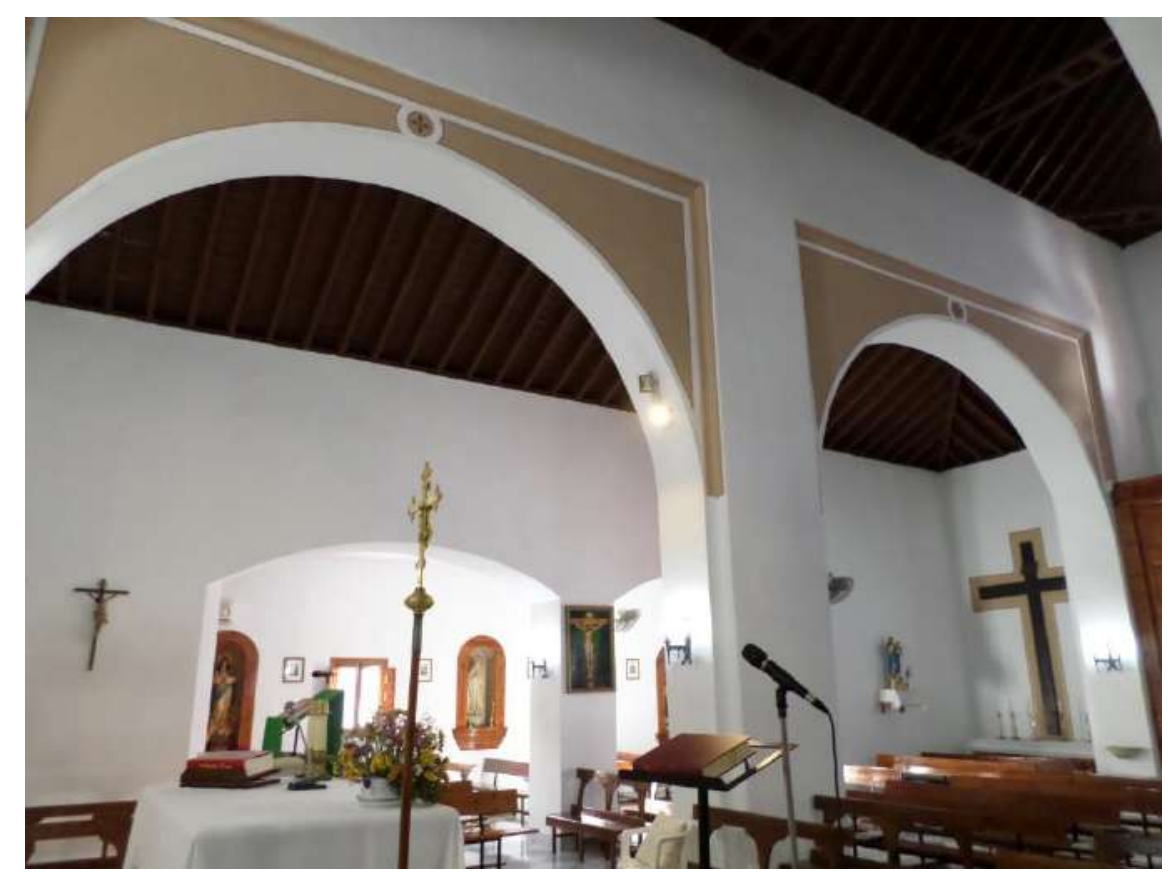

4) Arcos de acceso a naves laterales. 


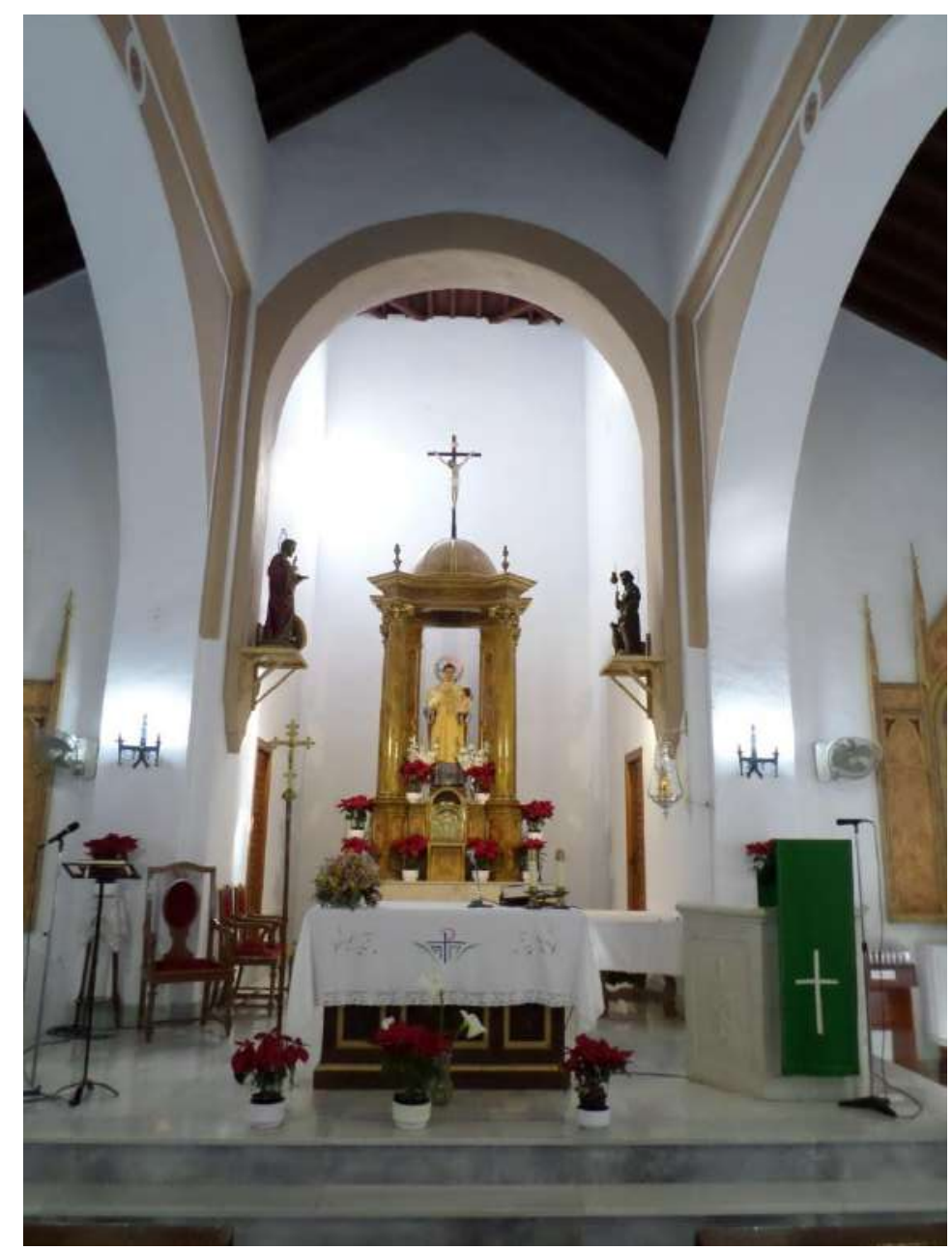

5) Arco toral de acceso a capilla mayor y capilla mayor.

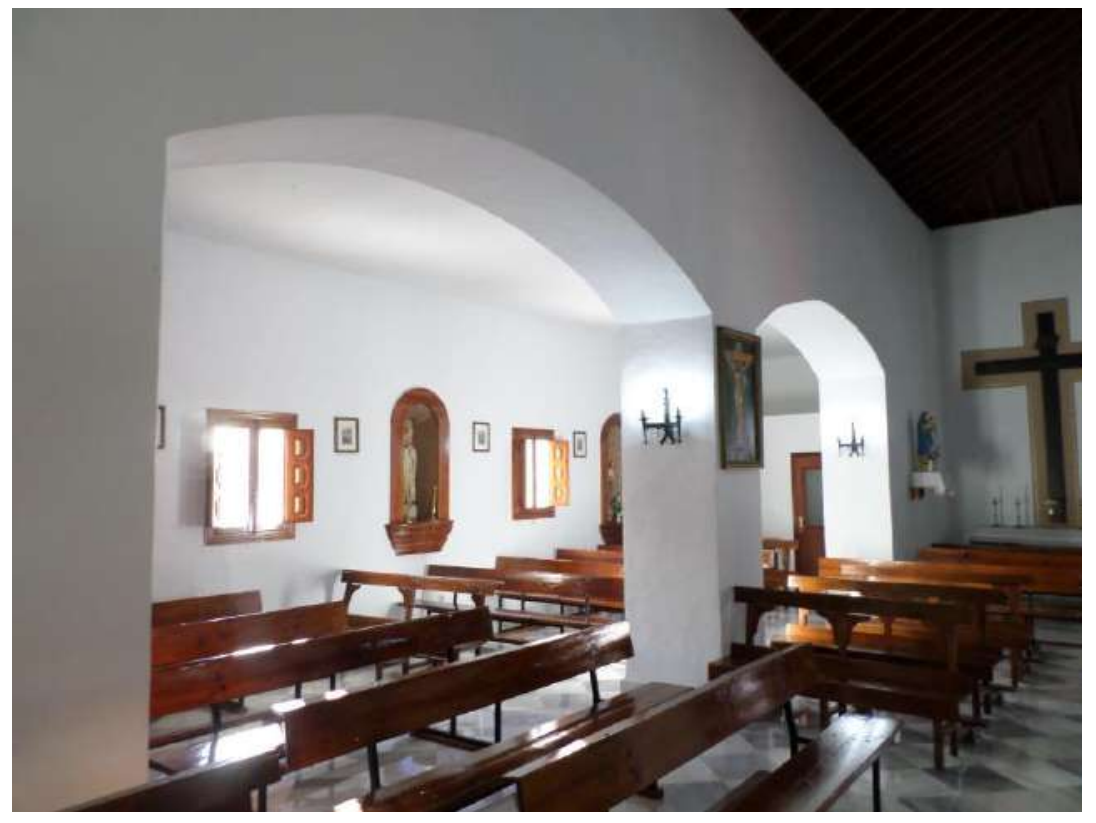

6) Nave realizada en el s. XX. 
En el exterior del templo podemos contemplar varias diferencias para ello vamos a describir este exterior por parte. Primero analizaremos la fachada principal. La fachada principal tiene la peculiaridad de tener en ella plasmada la configuración interna de la iglesia de tres naves, una central más elevada y dos laterales de menor altura, porque vemos esta disposición en altura y diferencia entre ellas claramente. Esta fachada está revocada ${ }^{174}$ pero en ella percibimos las cintas de ladrillo y yeso y los cajones de mampostería. La puerta de acceso al templo se encuentra en ella enmarcada por un arco de medio punto con clave y sostenido por pilastras dóricas. Este arco, a su vez, está rodeado por dos columnas que sostienen una cornisa. Un óculo corona este centro de la fachada e ilumina interiormente la nave central. El lateral y la cabecera de la iglesia, a diferencia de esta fachada principal, está sin revocar, por lo que en ellos podemos percibir las cintas de yeso y ladrillo y los cajones de mampostería.

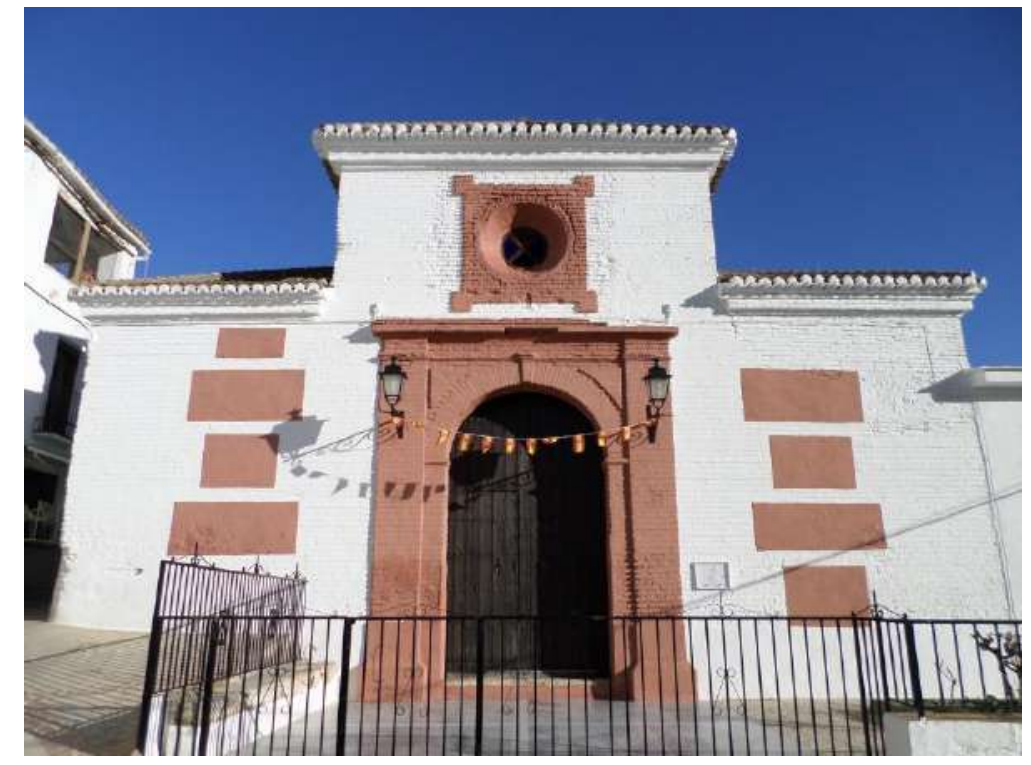

7) Fachada principal de la iglesia.

\footnotetext{
${ }^{174}$ Sabemos por testimonio vecinales que no estaba revocada antes de la Guerra Civil.
} 


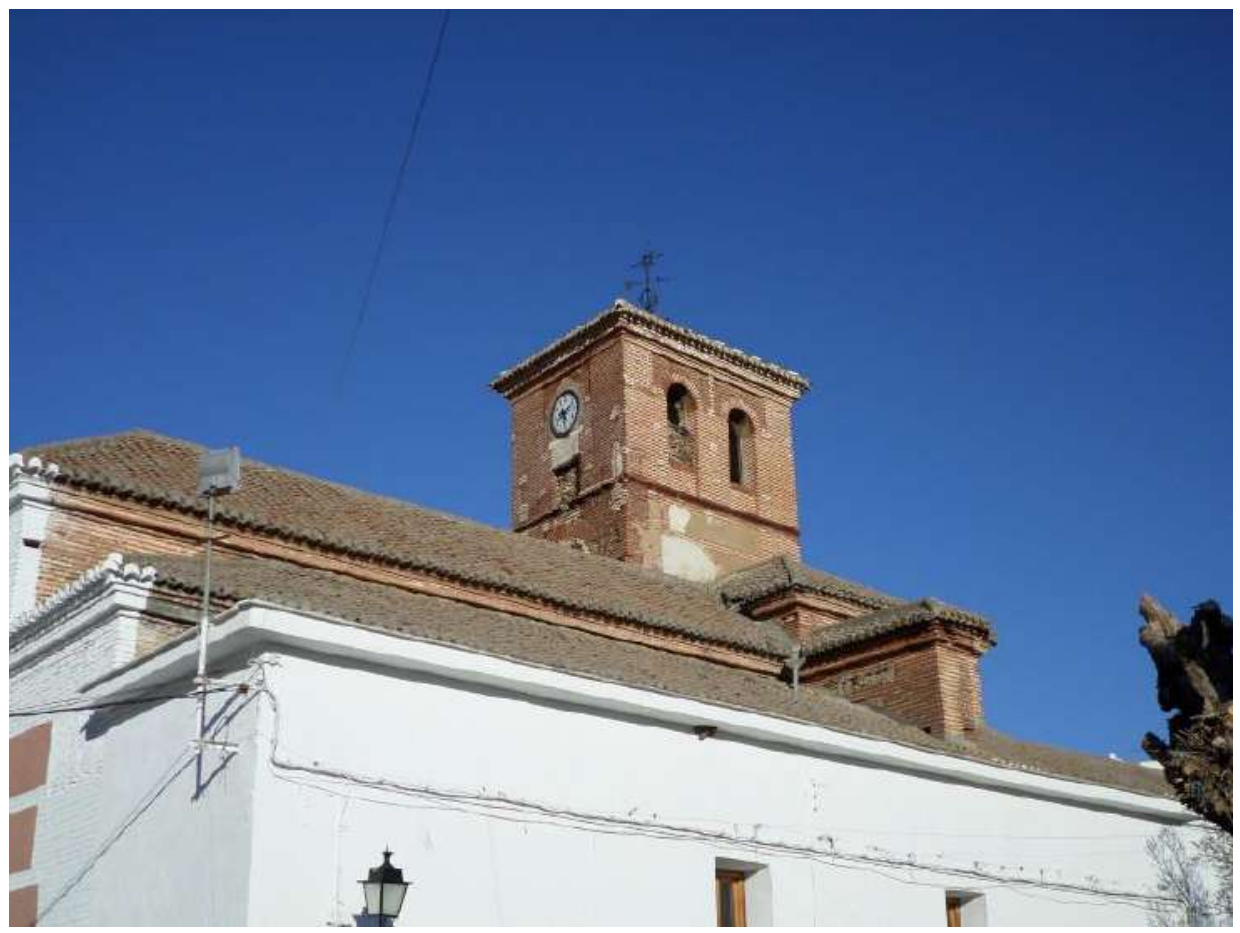

8) Laterales y torre de la iglesia sin revocar.

En el interior del templo, hemos de comentar que los muros de la iglesia son de cerramiento y cumplen la función de sustento del peso de los elementos superiores, son gruesos y producen gran sensación de solidez. En la capilla mayor hay un vano adintelado en la pared derecha y dos vanos adintelados se sitúan en la pared derecha de la nave ampliada en el siglo XX, iluminando el interior. La nave central, las naves laterales y la capilla mayor están cubiertas por armaduras de diferentes características, siendo las actuales reconstrucciones posteriores a la Guerra Civil ya que las anteriores fueron destruidas en esta contienda. ${ }^{175} \mathrm{La}$ armadura de la nave central es de par e hilera, con tirantes dobles sin decoración y sin canes por lo tanto apoyados directamente en el muro, no tiene almizate, aunque si tiene cuadrales dobles pero sin canes y sin decoración, y los pares tampoco tienen decoración. Las dos armaduras de las naves laterales presentan las mismas características, son de colgadizo y los pares no tienen ningún tipo de decoración. La armadura de la capilla mayor es de par e hilera, con cuadrales dobles sin canes y sin decoración, no tiene almizate y no tiene decoración en los pares.

175 VV.AA. Guía artística de Granada y su.... Op. cit., pág., 200. 


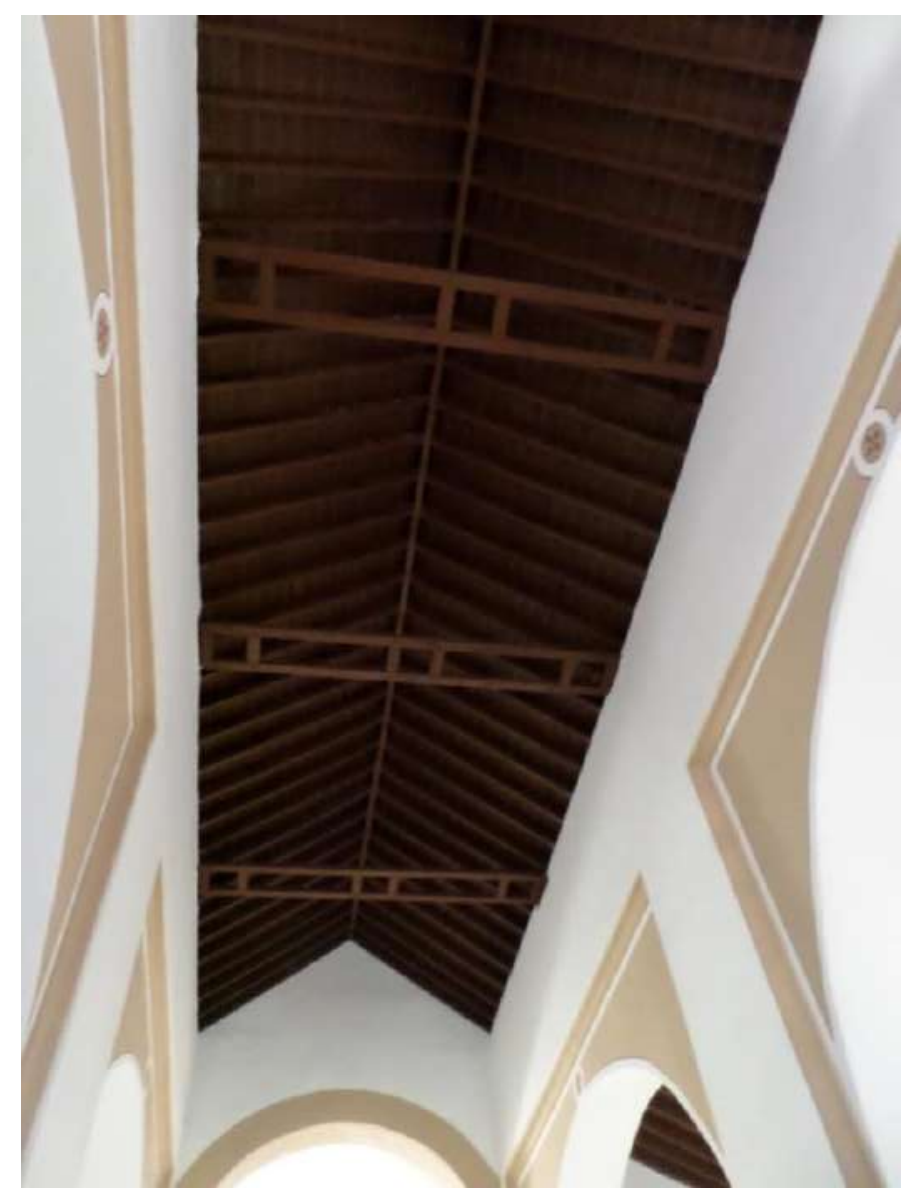

9) Armadura de la nave central de par e hilera.

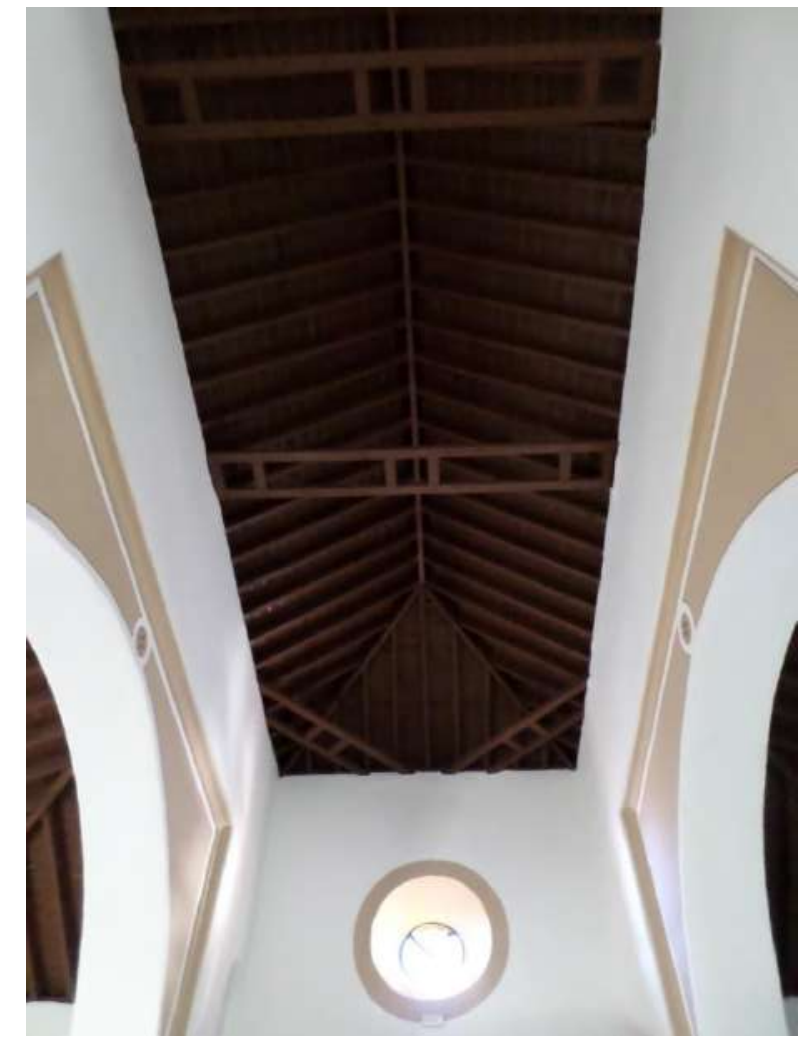

10) Detalle de la armadura de la nave central de par e hilera. 


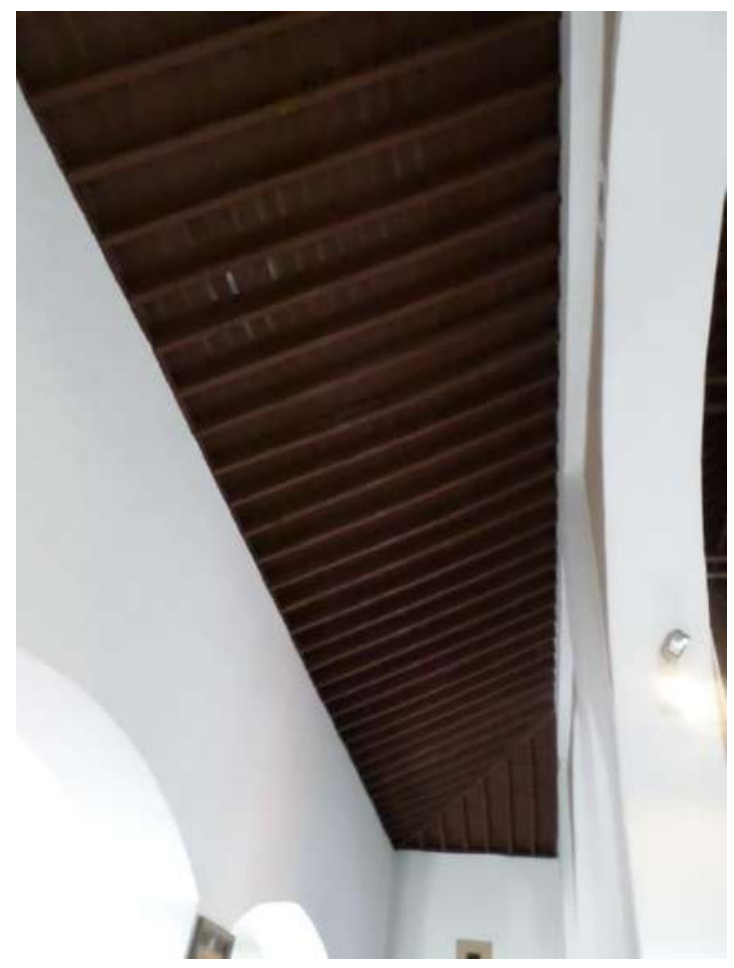

11) Armadura de colgadizo de la nave lateral derecha.

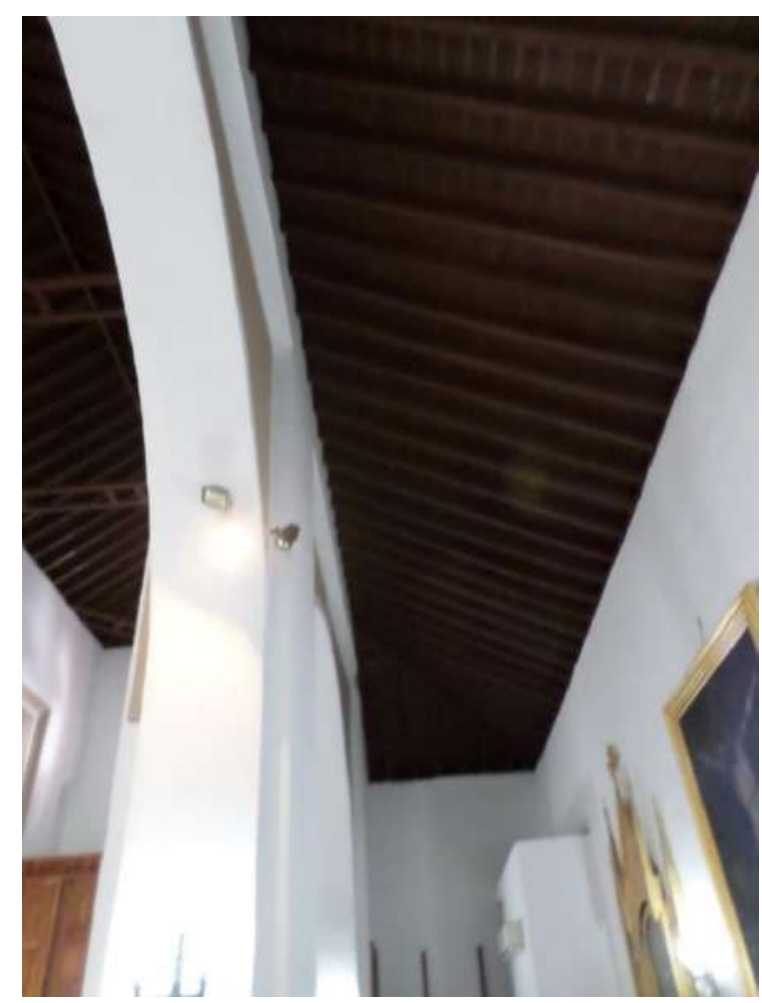

12) Armadura de colgadizo de la nave lateral izquierda. 


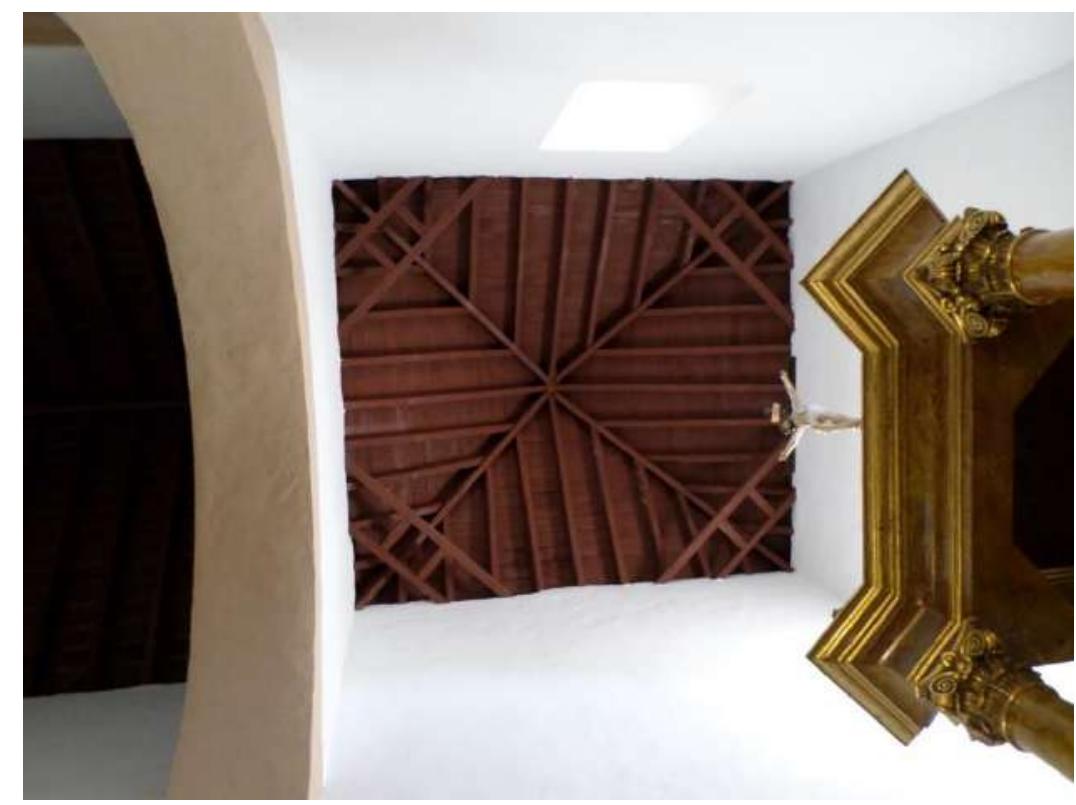

13) Armadura de la capilla mayor de par e hilera.

Por último, comentar la torre que se encuentra en el lado NO de la iglesia. Está construida en cintas de yeso y ladrillo y cajones de mampostería. Esta torre no está revocada totalmente, solo en su parte inferior, por lo que nos permite ver es realmente. Además, la torre presenta tres vanos adintelados con arcos de descarga en uno de sus lados, y presenta en el último cuerpo dos vanos con arcos de medio punto con alfiz cada uno que tendrían azulejos donde se sitúan las campanas.

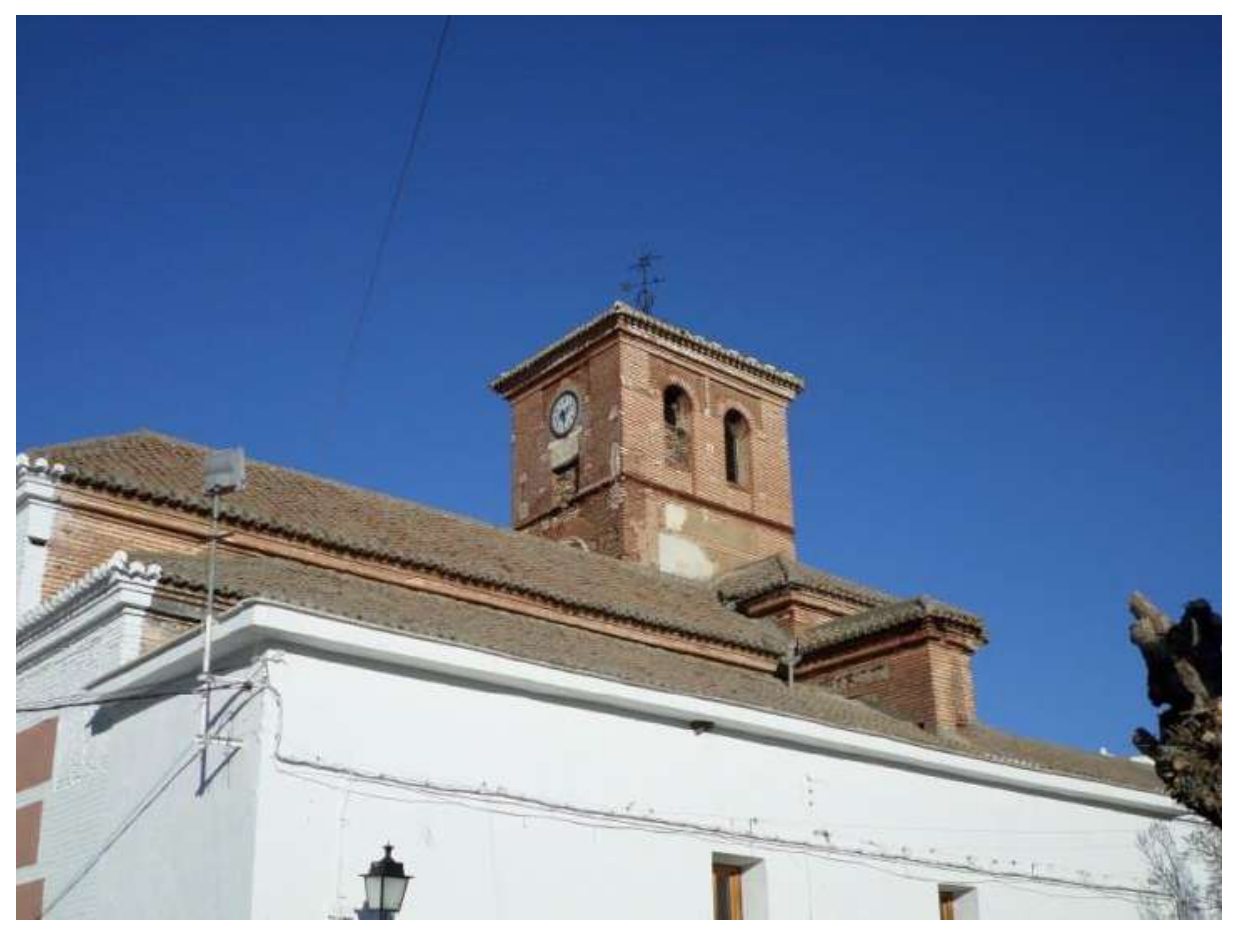

14) Situación de la torre en la iglesia. 


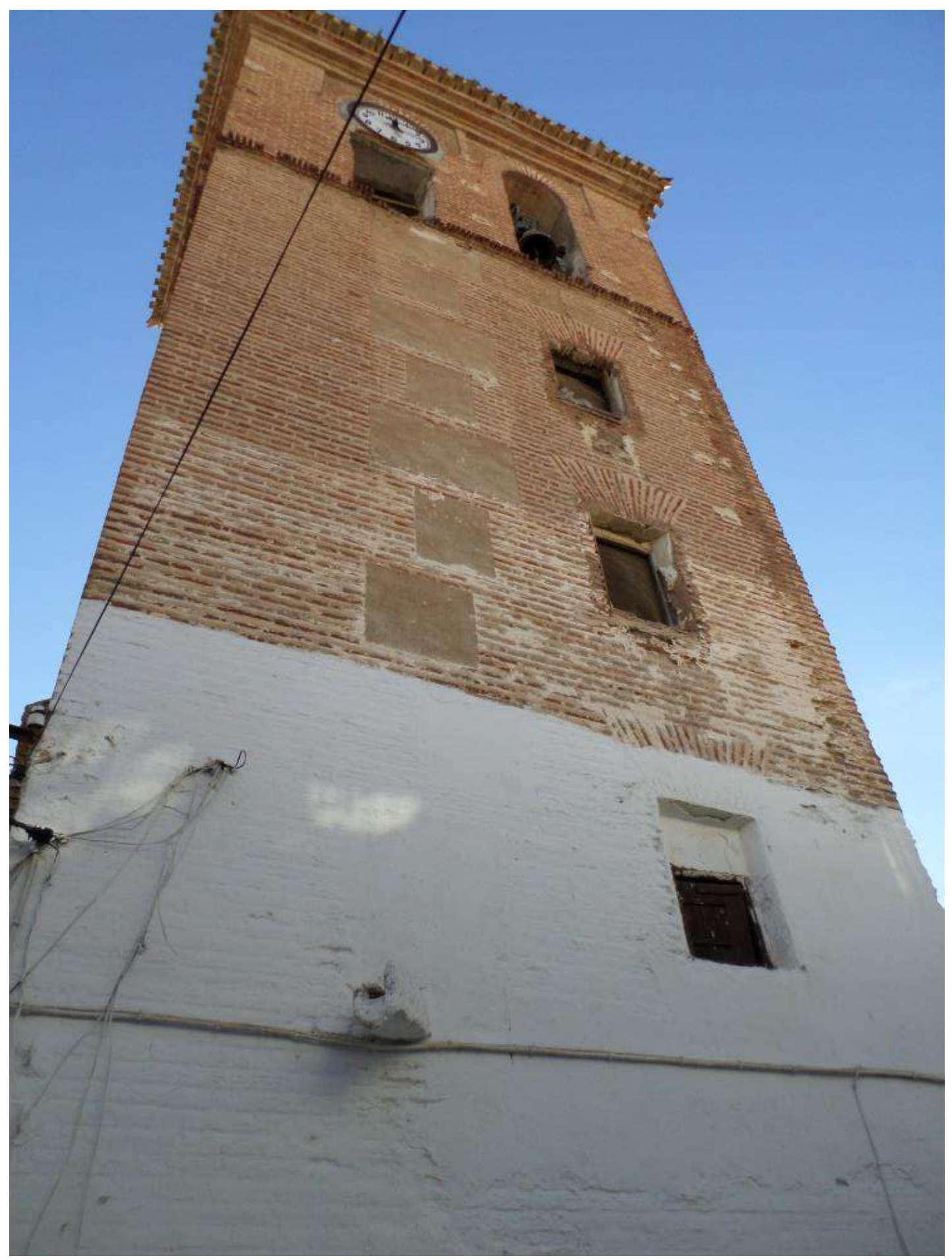

15) Torre. 


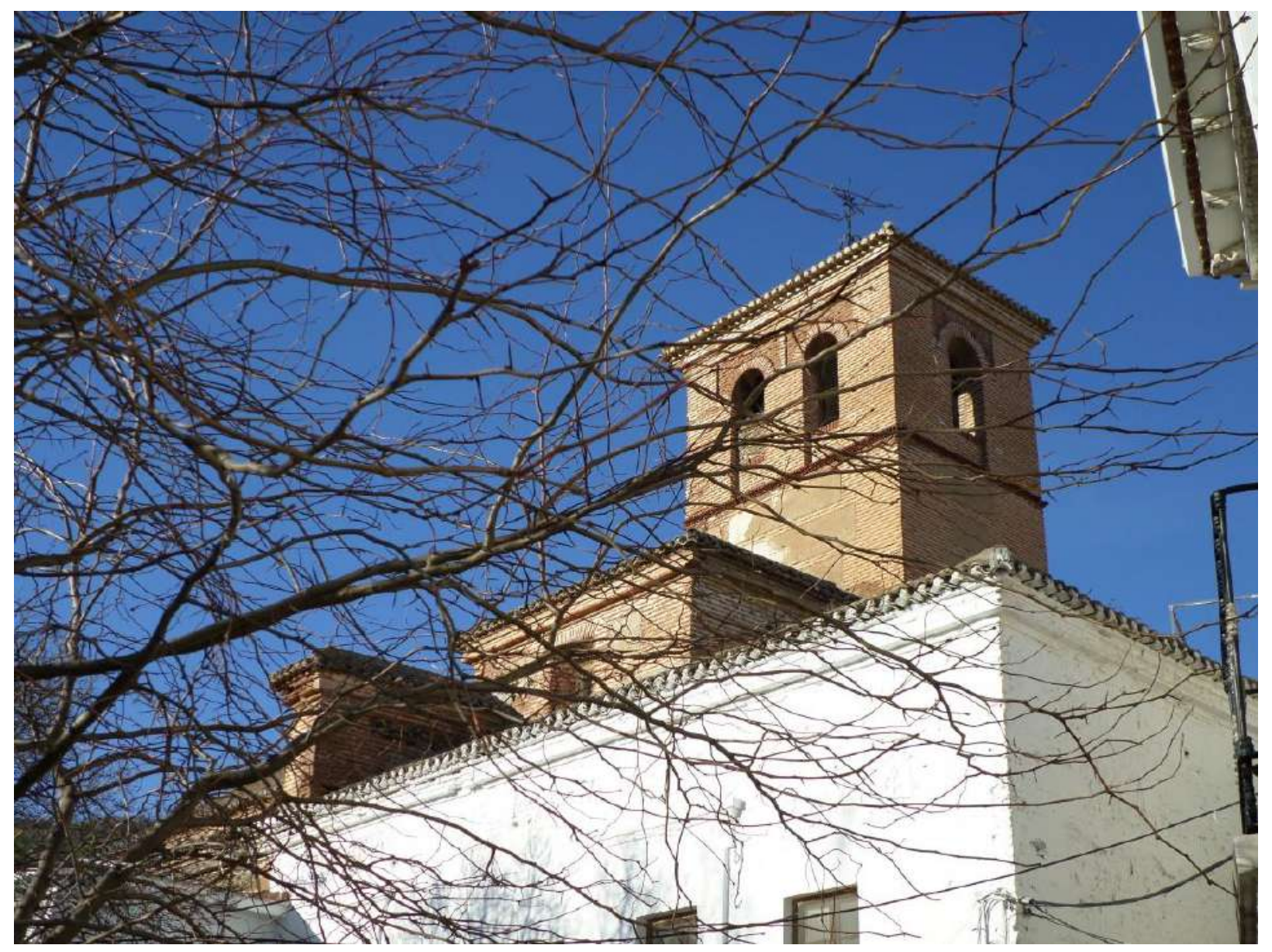

16) Vista de la torre.

De la iglesia descrita, la parte mudéjar sería, en primer lugar, la estructura espacial. Del exterior, las cintas de yeso y ladrillo y cajones de mampostería de todos los antiguos muros, la fachada principal con su predominante decoración y la torre. Del inmenso interior, la armadura de la nave central, las armaduras de las naves laterales y la armadura de la capilla mayor.

\subsection{Iglesia Parroquial San Luís Rey de Francia de Albondón.}

La Iglesia Parroquial de San Luís Rey de Francia es un templo erigido en 1707 aunque su fábrica actual es de 1735, proyectada por el albañil José Antonio de Morales. ${ }^{176} \mathrm{El}$ templo fue construido en piedra, ladrillo, yeso y madera, materiales que aparecen revocados en la fachada principal y en la torre. ${ }^{177}$

176 VV.AA. Guía artística de Granada y su.... Op. cit., pág., 190.

${ }^{177}$ Indicar que en este caso no tenemos conocimiento si la fachada principal y la torre estuvieron primitivamente sin revocar, podríamos pensar que por el carácter mudéjar de la iglesia sí, pero no podemos confirmarlo. 


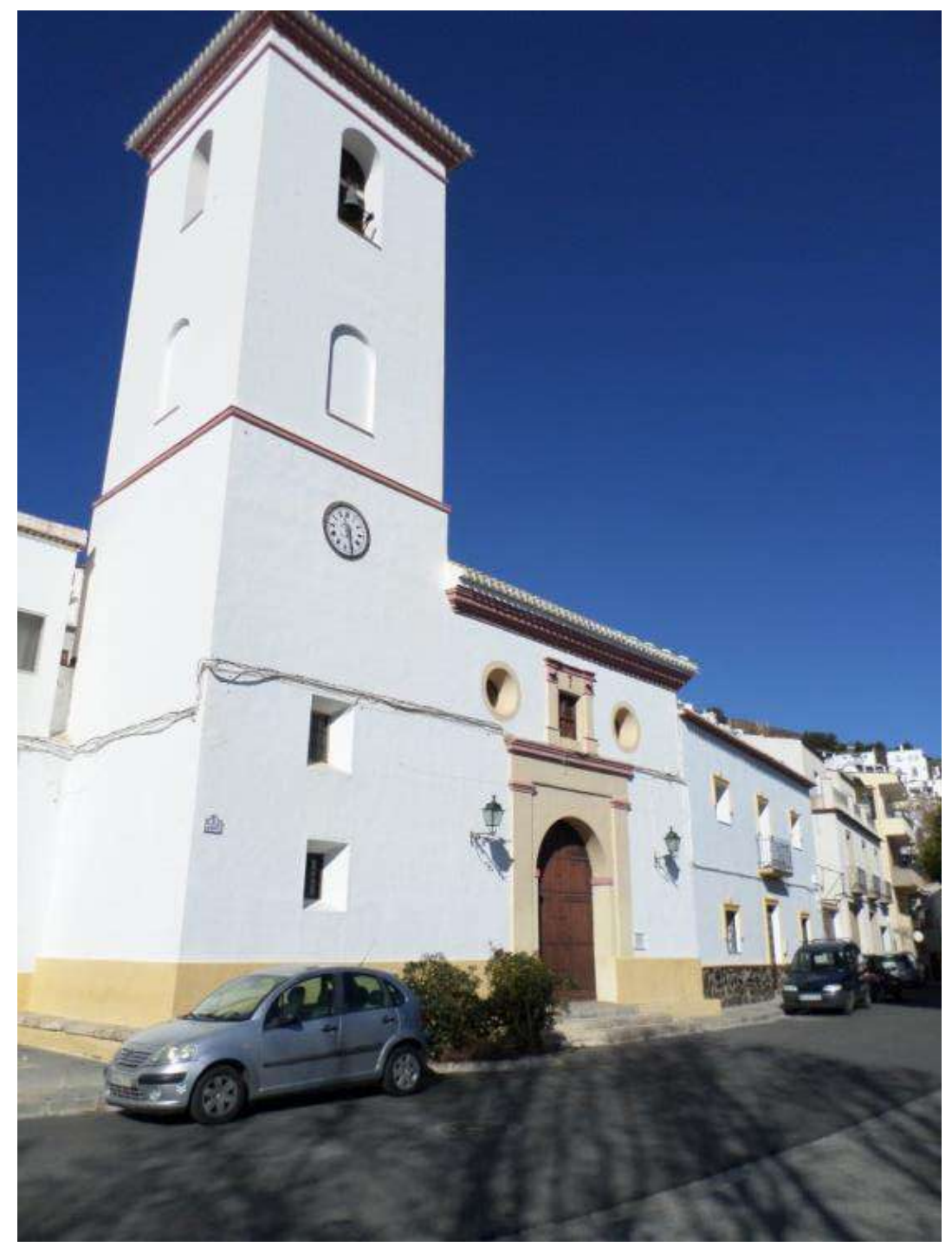

1) Iglesia Parroquial San Luis Rey de Francia.

La iglesia tiene tres naves separadas por tres arcos de medio punto y sin capilla mayor diferenciada. ${ }^{178}$ Estos arcos están pintados de color beige por fuera y en el intradós presentan una pintura que imita al mármol. La nave central y principal es más ancha y alta que las laterales, y presenta coro a los pies. La capilla mayor no está diferencia, pero se percibe por estar elevada por unas escaleras y por ella se accede a la sacristía. La nave lateral derecha presenta un arco de medio punto dentro de ella, dando lugar a una capilla y está decorado de la misma manera que los que dan acceso a esta nave.

${ }^{178}$ Este tipo de planta de tres naves separadas por arcos sobre pilares, aunque sin capilla mayor diferenciada, responde en cierta medida al esquema de tipología de iglesia mudéjares de Granada según el estudio realizado por Don Rafael López Guzmán e Ignacio Henares Cuéllar en:

- $\quad$ HENARES CUÉLLAR, Ignacio; LÓPEZ GUZMAN, Rafael. Arquitectura Mudéjar.... Op. cit. 


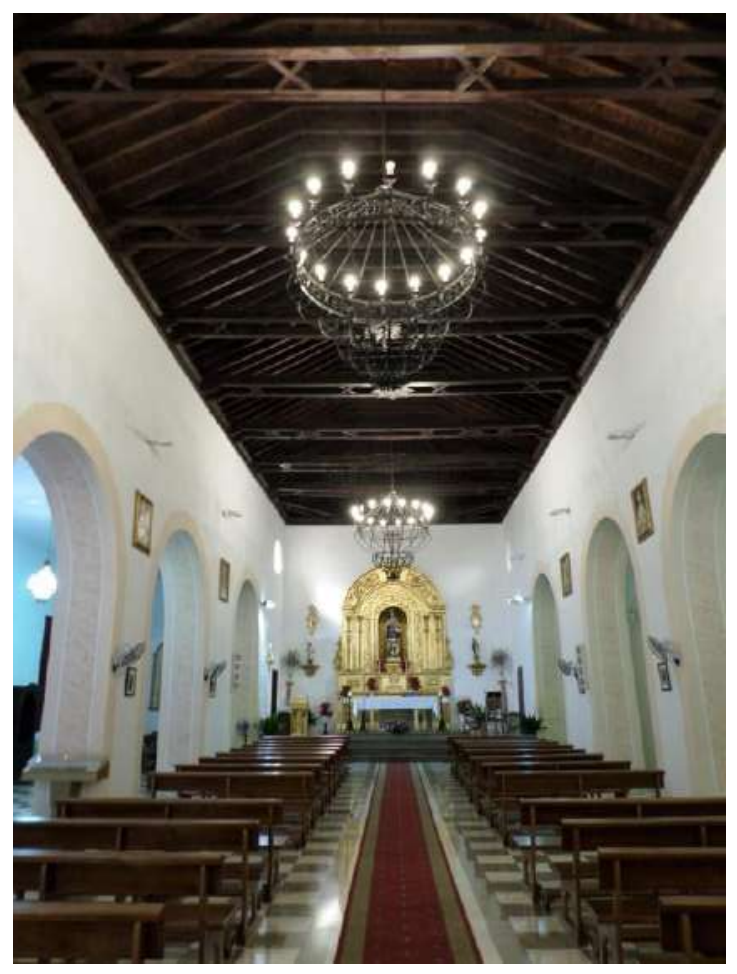

2) Vista de la nave principal de la iglesia.

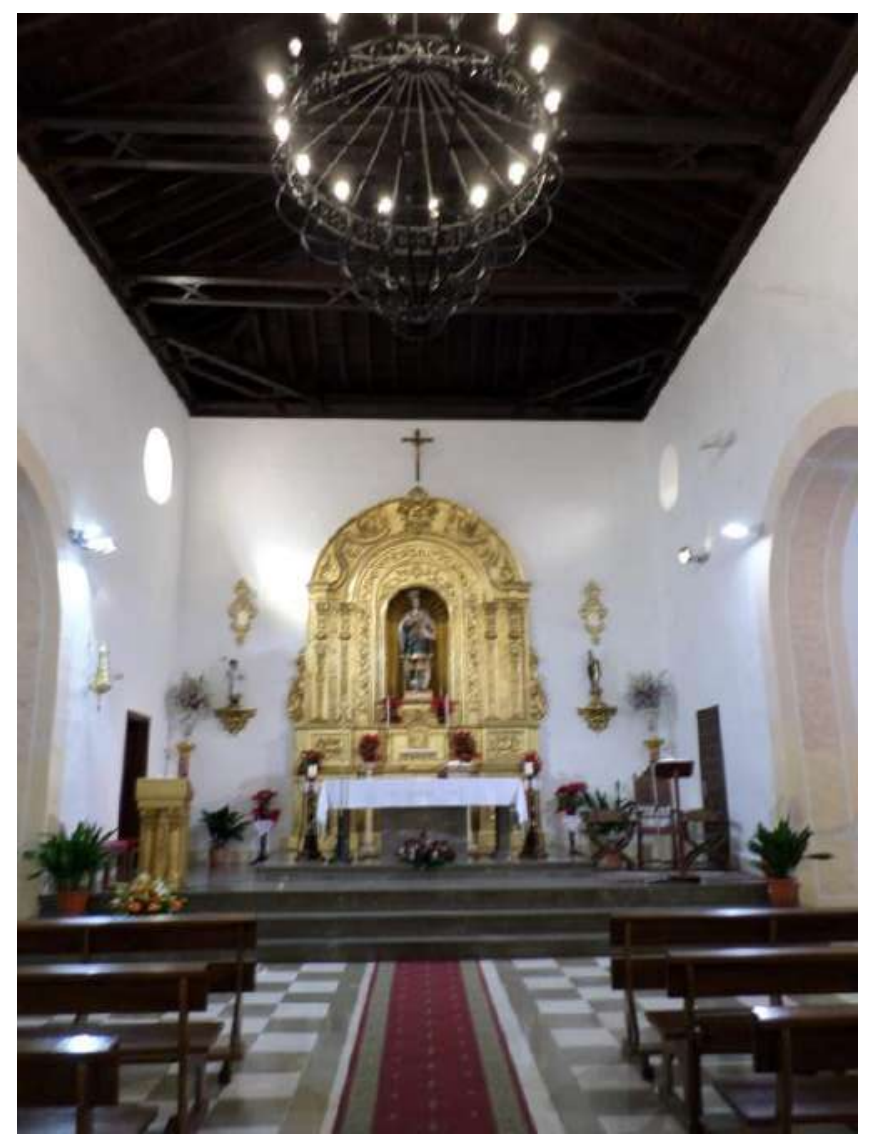

3) Capilla mayor. 


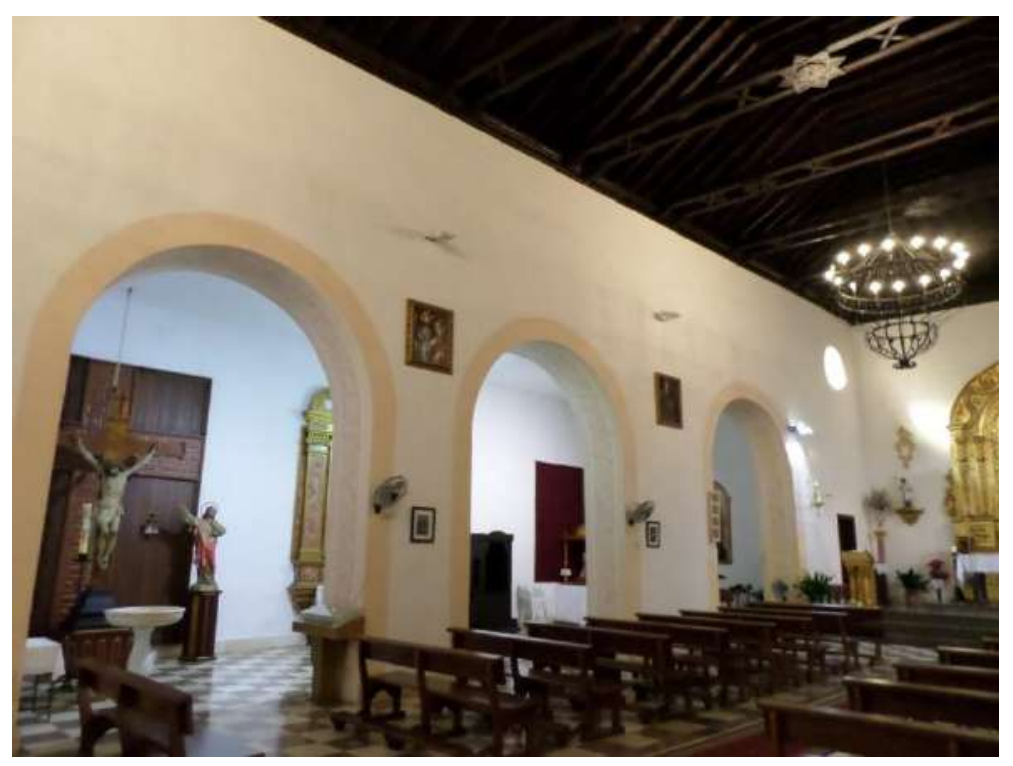

4) Arcos de acceso a nave lateral izquierda.

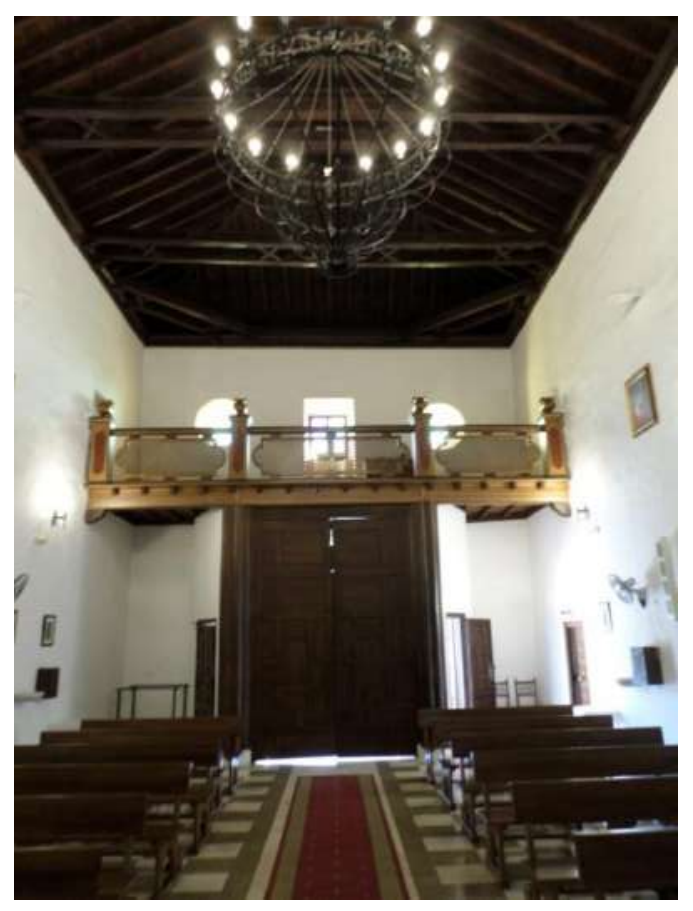

5) Coro.

Exteriormente, solo podemos ver la fachada principal ya que la iglesia está rodeada hoy en día por edificaciones contemporáneas. En primer lugar, observamos la torre en el lado izquierdo de la fachada principal. Esta torre tiene dos vanos en su cuerpo inferior, un arco de medio punto en el tercer cuerpo y un arco de medio punto en 
sus cuatro lados en el último cuerpo donde se colocan las campanas. La fachada principal tiene la puerta de acceso enmarcada por un predominante arco de medio punto apoyado en dos pilastras dóricas, rodeado a su vez por dos pilares dóricos que sostienen un arquitrabe liso y una cornisa. Un vano adintelado aparece encima enmarcado por pilastras dóricas que sostienen una cornisa y franqueado por dos óculos. Todos estos elementos están pintados de dos colores, granate y beige, alternativamente, siendo el blanco el color de la fachada.

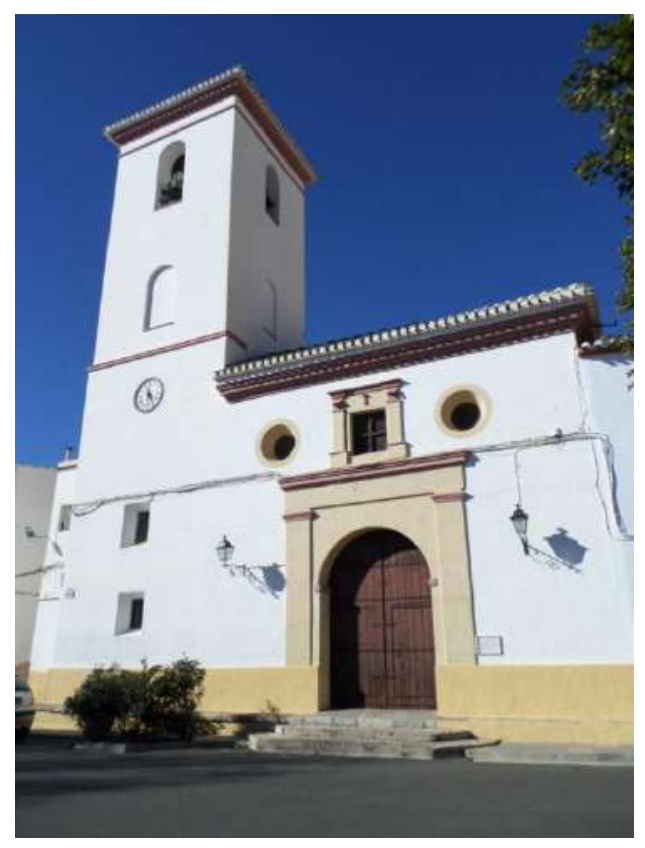

6) Fachada de la iglesia.

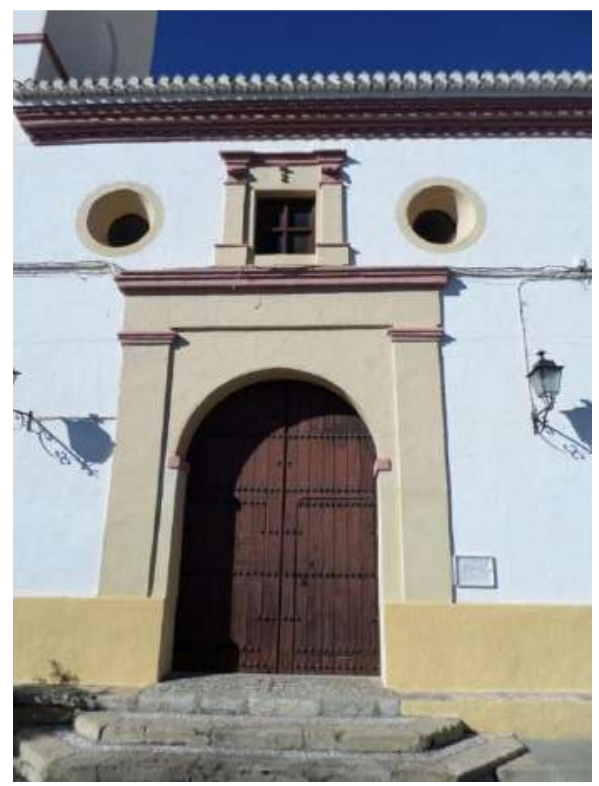

7) Portada de la iglesia. 
Pasando al interior, hemos de indicar que los muros son los principales elementos sustentantes de la iglesia y cumples la función de cerramiento y sustento del peso de los elementos superiores, además dan gran sensación de solidez. La nave principal presenta dos óculos en la zona de la capilla mayor que la ilumina interiormente. También, esta nave está cubierta por una armadura reconstruida tras los destrozos acaecidos en la Guerra Civil española, pero la primitiva junto con toda la carpintería de la iglesia fue obra de Alfonso de Aguirre. ${ }^{179}$ Esta armadura es de lima bordón, con tirantes pareados que se apoyan en canes lobulados y tiene cuadrales dobles. Destacar que tanto los tirantes como los cuadrales tienen chillas, pero hay tirantes que presentan algunas peculiaridades decorativas en el centro de los mismos, como es el caso del tirante cinco, sin contamos los tirantes desde la puerta de entrada, que tiene una rueda enmarcada por una estrella de ocho puntas; el tirante seis tiene una estrella de ocho puntas, el tirante siete en sus extremos tiene ruedas insertas en estrellas de seis puntas; también el tirante ocho, en cuyo centro hay una estrecha de dieciséis puntas, y en el tirante nueve, una estrella de nueve puntas, ya en la capilla mayor. Los pares de la armadura no tienen decoración, lo mismo que tampoco presente el almizate. El coro está sostenido por un alfarje que es también una reconstrucción. Este alfarje está formado por dos jácenas, y la primera de ellas tiene canes lobulados. Ocho jaldetas ${ }^{180}$ se apoyan sobre estas jácenas y sobre las jaldetas están montadas las tablazones. Hay que indicar que el alfarje no presenta ningún tipo de decoración. Las naves laterales están cubiertas por un techo plano.

${ }^{179}$ VV.AA. Guía artística de Granada y su.... Op. cit., pág., 190.

${ }^{180}$ Ochos son las jaldetas por lo que hemos podido observar a simple vista en el trabajo de campo ya que el alfarje está cubierto parcialmente por un sotocoro que lo divide y que no permite el visionado completo del mismo. 


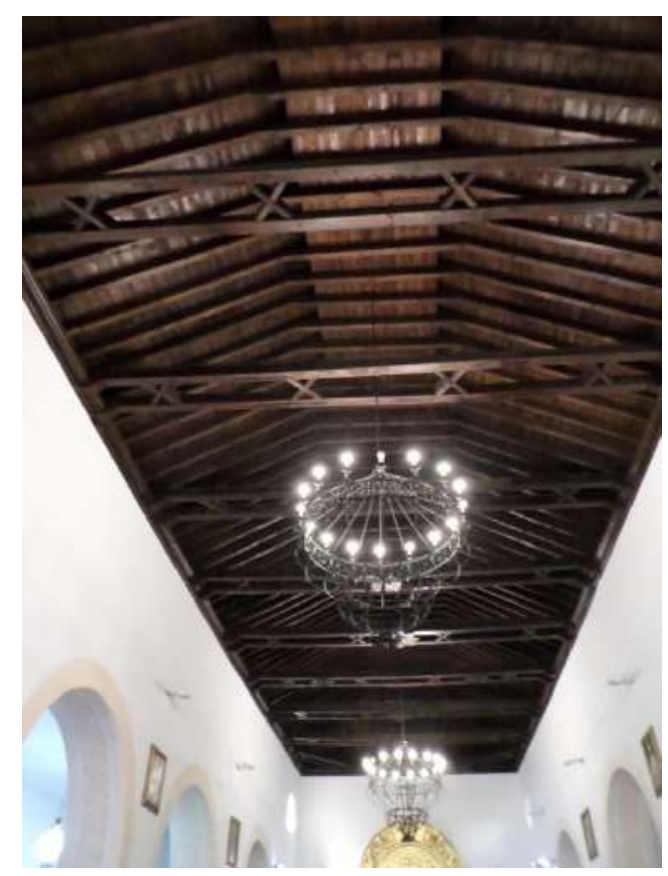

8) Armadura de la nave principal.

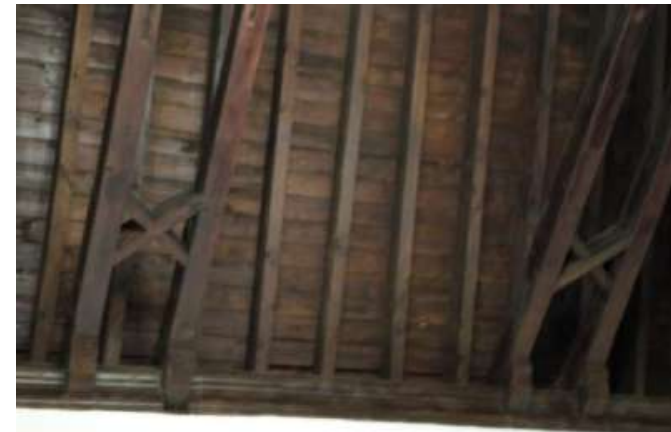

9) Canes lobulados.

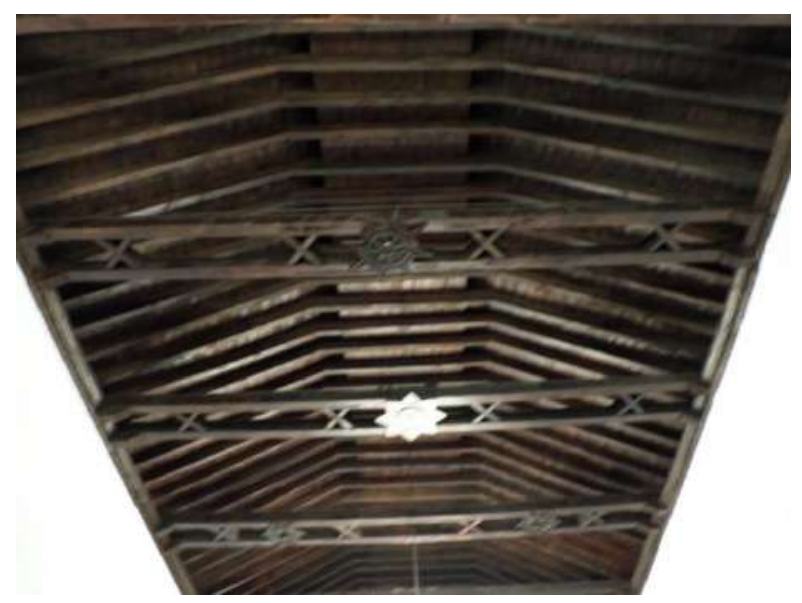

10) Detalle de estrellas en el centro de la armadura. 


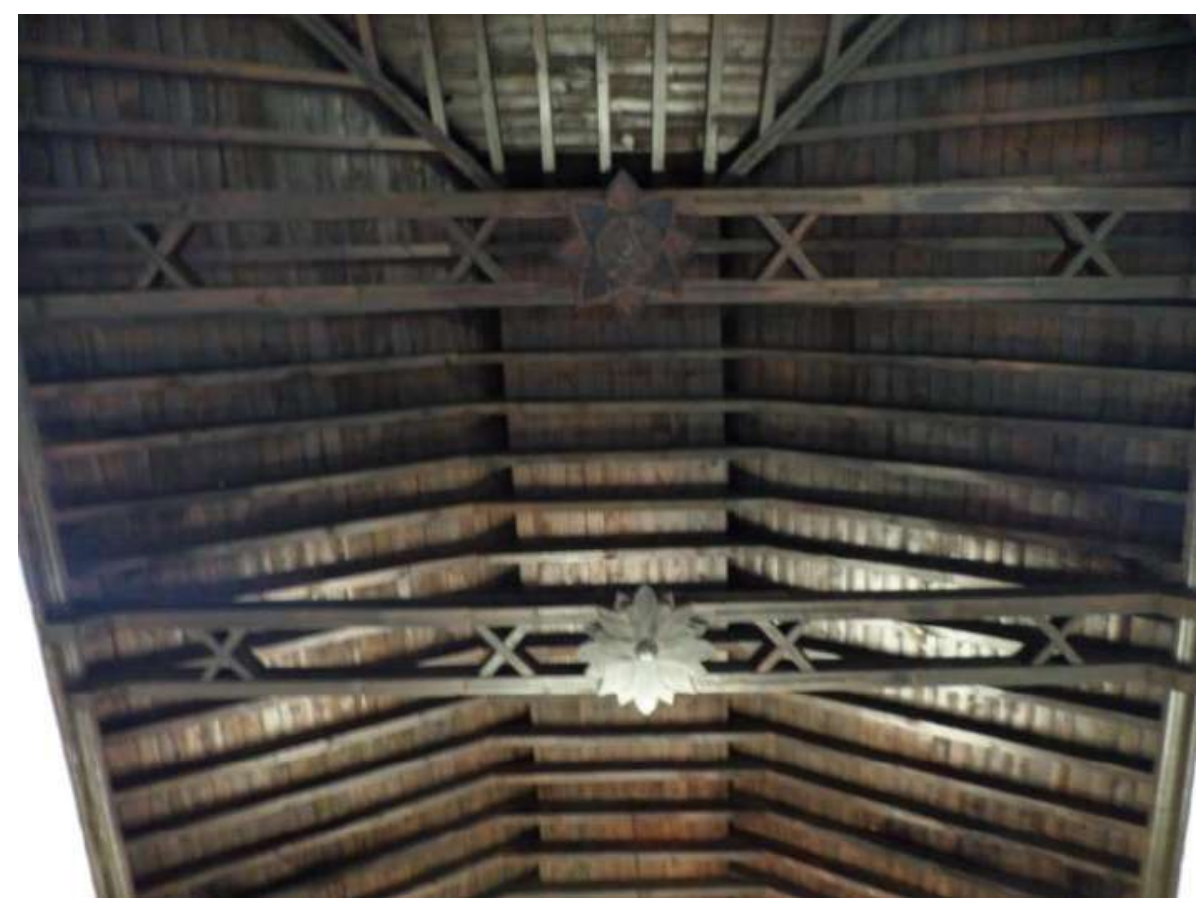

11) Detalle de estrella cerca del altar mayor.

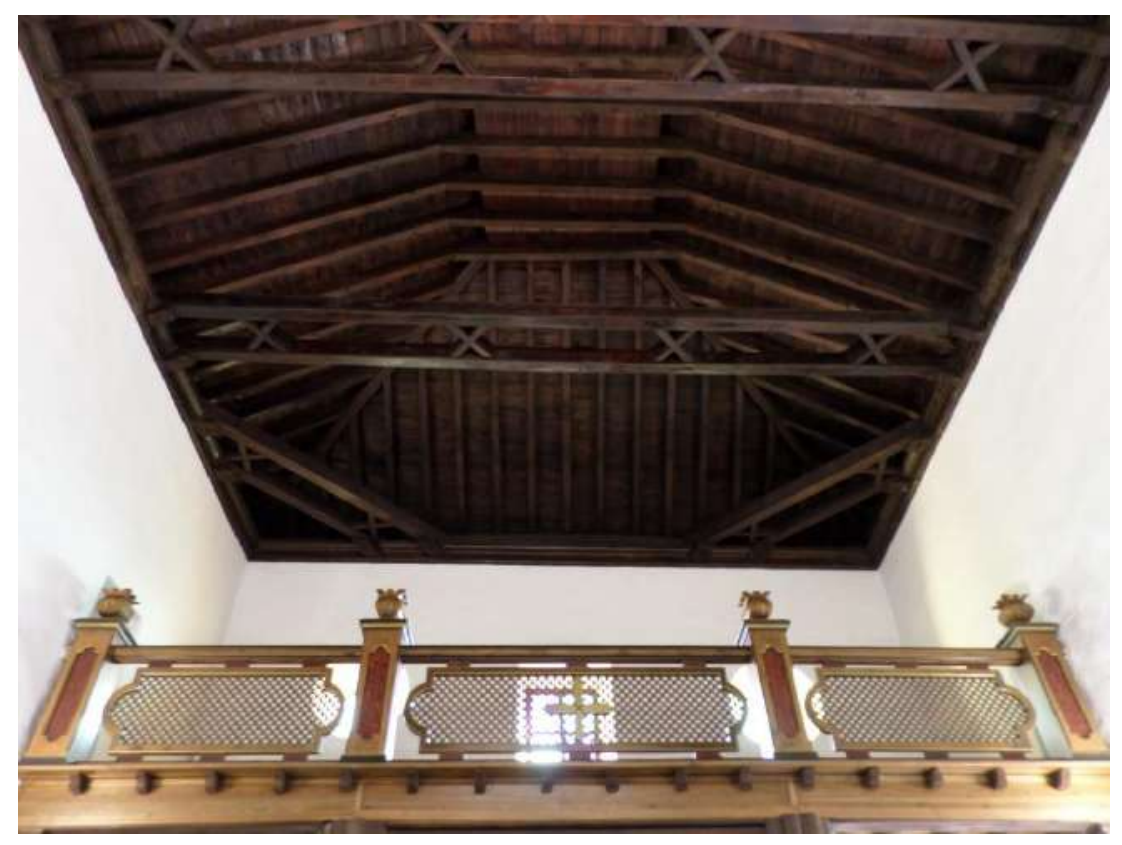

12) Detalle de armadura en el coro. 


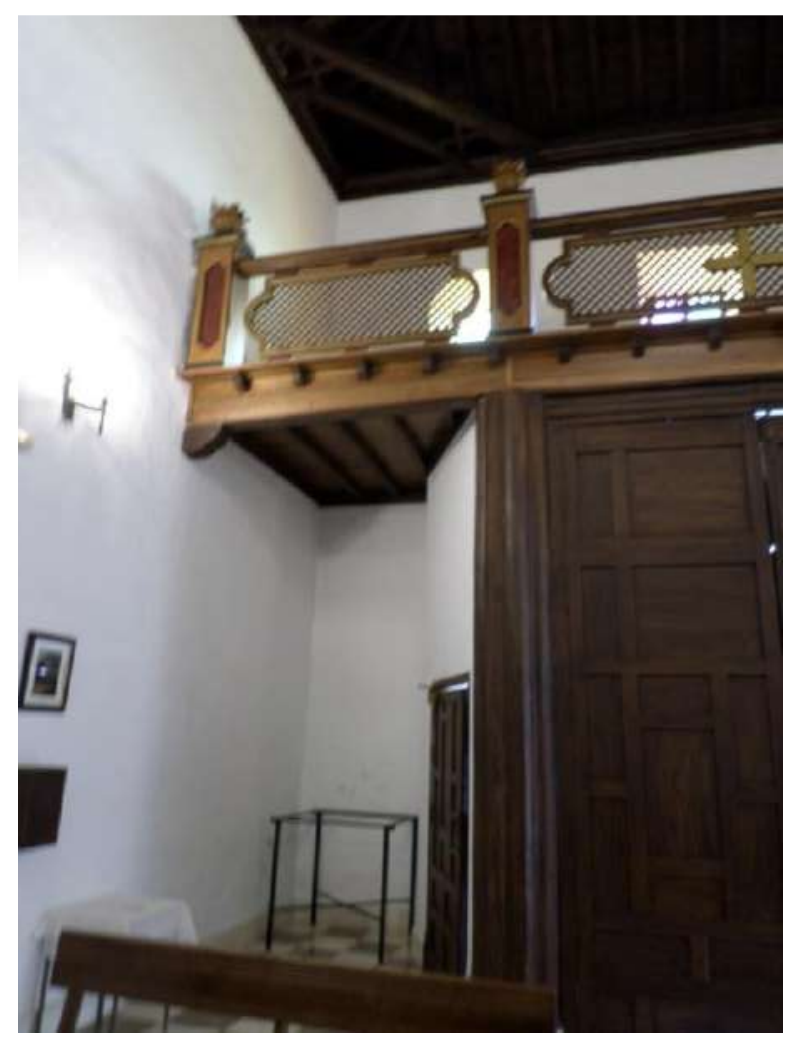

13) Detalle del alfarje del coro.

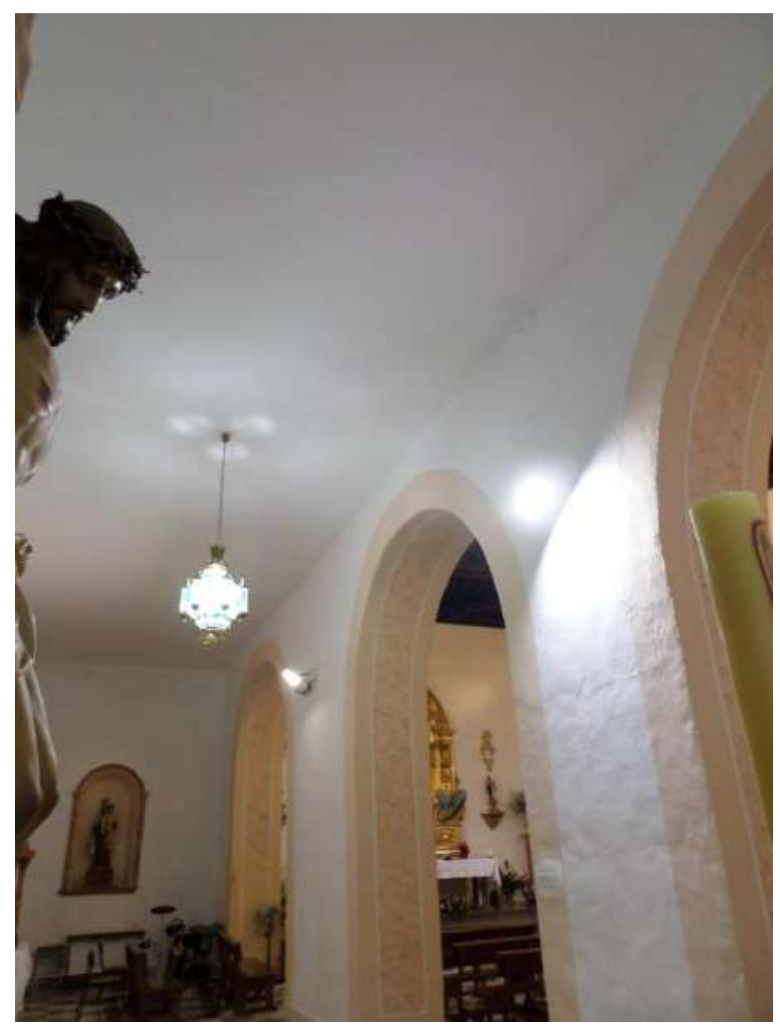

14) Nave lateral izquierda. 


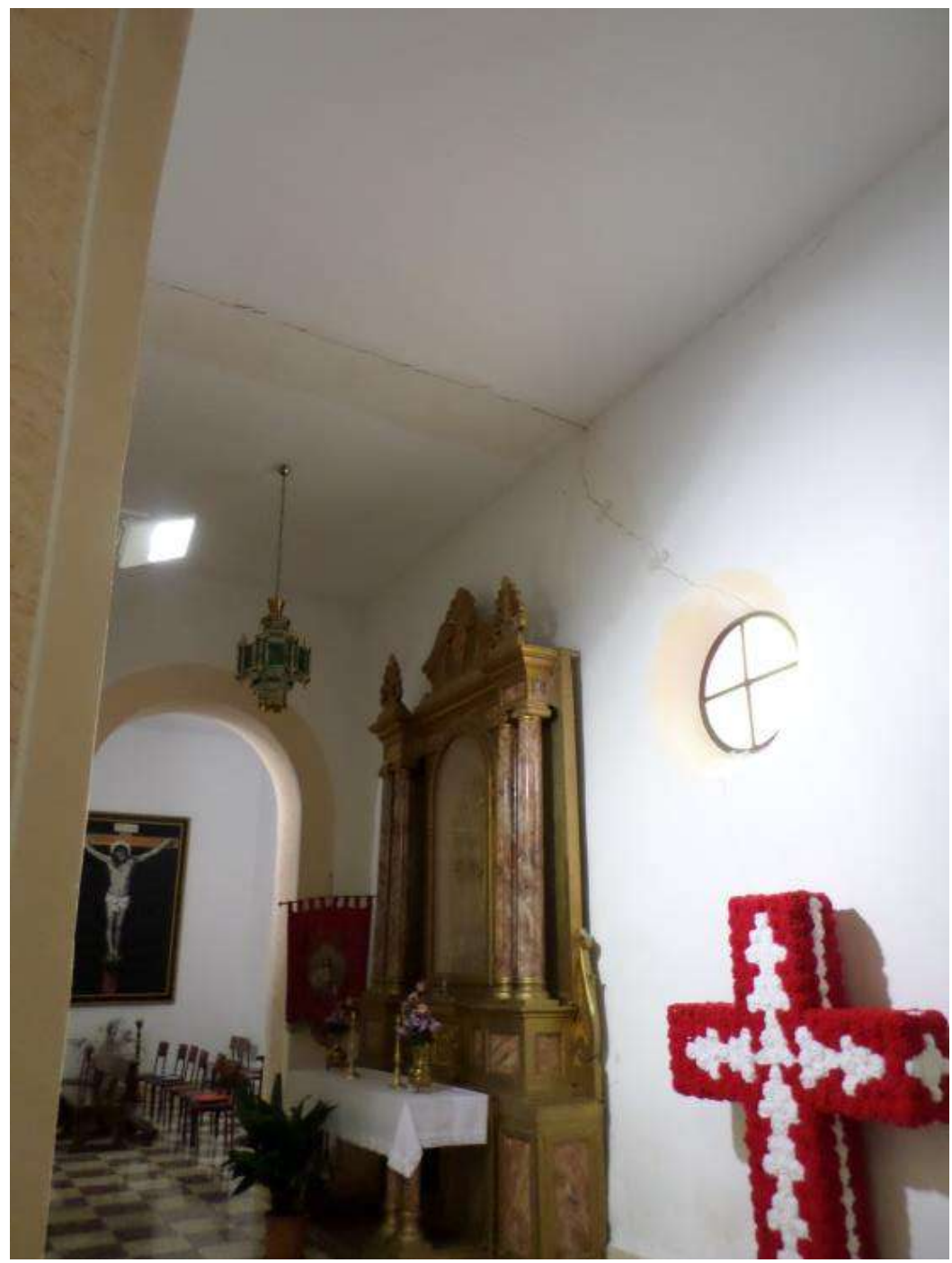

15) Nave lateral derecha.

De la iglesia descrita, la parte mudéjar sería, en primer lugar, la estructura espacial. Del exterior la fachada principal y la torre. Del interior, la antigua y gran armadura de la nave central y el moderno alfarje que sostiene el coro. 


\section{Conclusiones.}

En el trabajo de estudio analítico tanto histórico de la situación de los musulmanes bajo la Corona de Castilla, como en el estudio de las iglesias mudéjares de la costa de la provincia de Granada, podemos constatar que:

- La realidad política y social de la Costa de Granada durante el período mudéjar y morisco fue un período difícil para los musulmanes bajo la jurisdicción de la Corona de Castilla, que, aunque se llegaron a los acuerdos en las Capitulaciones, estas se aplicaron parcialmente por parte de los castellanos. Pero a pesar de estas dificultades, hubo sectores musulmanes que colaboraron con la Corona, preservando su estatus social antiguo y que le ayudaron a los cristianos a gobernar el territorio, algo muy normal si entendemos que estos colaboradores no querían ver mermada su situación y posición económica, aunque en todo esto se produjeron abusos. Estos abusos provocaron enfrentamientos entre comunidades y claro, como era de esperar los musulmanes se aliaron con sus hermanos del Norte de África para atacar a los cristianos, pero eso tuvo sus represalias, con prohibiciones e impuestos. La vida la desarrollaron fundamentalmente en las antiguas alquerías heredas del sistema nazarí, ya que Castilla no socavó con dicha estructura administrativa, aunque si les dio mayor importancia a las medinas, convirtiéndolas en cabeza de distrito, al igual que se respetó la administración económica. Con las conversiones forzosas, algo que propició otras capitulaciones, el estatus de estos musulmanes cambió, pasando a denominarse moriscos, pero su mala fama seguía siendo la misma, y la enemistad entre comunidades seguía estando.

- Todas las iglesias mudéjares de la costa de la provincia de Granada que hemos estudiado se han construido entre el s. XVI y el s. XVIII de tal manera que el periodo mudéjar en la costa podemos establecerlo en esas fechas.

- Las iglesias de la costa de la provincia de Granada que hemos estudiado e investigado son iglesias en las que vemos claramente que el mudéjar es el estilo predominante y esencial en su estructura externa e interna, por todos y 
cada uno de los elementos que hemos ido describiendo (cintas de ladrillo y yeso, cajones de mampostería, armadura, aljarfe, alfiz, portadas de ladrillo).

- Todas las Iglesias de las Costa de la provincia de Granda que hemos estudiado responden a los esquemas de tipología de Iglesias Mudéjares de Granada según el estudio realizado por expertos en nuestro objeto de estudio.

- Los materiales de construcción de estas iglesias han sido la piedra, el ladrillo, el yeso y la madera, materiales propios mudéjares, heredados de las construcciones islámicas. Aunque podríamos pensar que estos materiales están en todas las iglesias, pero el modo en que se han configurado y se han dispuesto en el exterior, en las armaduras, los alfarjes, los cajones de mamposterías, las cintas de yeso lo hacen herederos de una tradición islámica que solo se perciben en estos templos.

- Las armaduras que cubren las naves principales o capillas mayores, y alfarjes que sostienen el coro situados a los pies han sido los elementos característicos de la mayor parte de las iglesias que hemos estudiado, salvo algunas excepciones, aunque no presentan decoración algunas de ellas.

- A lo largo del tiempo estas iglesias han sufrido transformaciones de tal manera que esos elementos mudéjares o han sido ocultados o han desaparecido, como la armadura de la Iglesia Parroquial de San Miguel de Gualchos que desapareció en la Guerra Civil, o incluso a las plantas de la iglesia se les ha añadido otra nave lateral o capilla mayor, como hemos podido estudiar en las diferentes iglesias. Esto puede hacernos pensar el mudéjar en la iglesia no esté, se haya perdido o simplemente no se tenga en cuenta, pero no es esta la realidad. En algunos templos puede parecer que ocurre esto, pero por un análisis pormenorizado de ellos, como el que hemos realizado, definimos claramente que es lo original, que es lo mudéjar, lo original de la iglesia, de las adicciones posteriores, gracias a testimonios, a documentos y a fotografías antiguas, hemos llegado a ver el proceso histórico de la iglesia. 
- La arquitectura actual de estas iglesias es algo esencial para entender la situación en la que se encuentran. Hoy día estas iglesias se encuentran transformadas, como hemos descrito en los respectivos análisis de cada una de ellas, pero muchas de estas iglesias conservan los elementos esenciales que las configuran como iglesias mudéjares. Aunque no solo es el mudéjar lo que se encuentra en ellas, algo que no hemos analizado ya que no es el objeto de nuestro estudio.

- La consciencia de la importancia de conservar este inmenso y rico patrimonio histórico y artístico lo hemos visto en los propios habitantes de los pueblos en los que se encuentran las iglesias ya que van aportando recursos para su conservación y protección, y esto lo hemos constatado cuando les hemos preguntado en el proceso de investigación y también en el estado en que se encuentran las propias iglesias, en un estado bastante positivo. 


\section{Bibliografía y Webgrafía.}

\section{Bibliografía.}

- CARO BAROJA, Julio. Los Moriscos del reino de Granada. Madrid:

Ediciones Itsmo, S.A., 1991.

- CASTILLO FERNÁNDEZ, Javier. "Las estructuras sociales”. En:

BARRIOS AGUILERA, Manuel (Coord.). Historia del Reino de Granada II. La época morisca y la repoblación (1502-1630). Granada: Editorial Universidad de Granada, El Legado Andalusí. 2000.

- DOMÏNGUEZ GARCÍA, Manuel. “La Iglesia de Capuchinos”. En: VV.AA. El Patrimonio artístico de Motril. Motril: Ayuntamiento de Motril. Área de Cultura y Patrimonio, 2003. págs., 159-165.

- DOMÍNGUEZ GARCÍA, Manuel. “La Iglesia de la Victoria”. En: VV.AA. El Patrimonio artístico de Motril. Motril: Ayuntamiento de Motril. Área de Cultura y Patrimonio, 2003. págs. 79-87.

- DOMÍNGUEZ GARCÍA, Manuel. “La Iglesia Mayor de la Encarnación”. En: VV.AA. El Patrimonio artístico de Motril. Motril: Ayuntamiento de Motril. Área de Cultura y Patrimonio, 2003. págs. 47-57.

- DOMÍNGUEZ GARCÍA, Manuel. La Iglesia Mayor de Motril: cinco siglos de evolución histórica de su fábrica. Motril: El Autor, 1983.

- El Faro. 9/10/1935.

- GALÁN SÁNCHEZ, Ángel. Los mudéjares del Reino de Granada. Granada: Universidad de Granada, Diputación Provincial de Granada. 1991.

- GALÁN SÁNCHEZ, Ángel. Una sociedad en transición: los granadinos de mudéjares a moriscos. Granada: Universidad de Granada. 2010.

- GALLEGO BURÍN, A. Informe sobre las pérdidas y daños sufridos por el Tesoro Artístico de Granada de 1931 a 1936 e indicación de las obras salvadas de la destrucción marxista, redactado por el Seminario de Arte de la Universidad de Granada y el Servicio Artístico de Vanguardia. Granada: Imprenta $\mathrm{H}^{\mathbf{o}}$. de Paulino Ventura, 1937., pág. 109.

- GÓMEZ-MORENO CALERA, J.M. La arquitectura religiosa granadina en la crisis del Renacimiento (1560/1650). Granada: Editorial de la Universidad de Granada, 1989. 
- GÓMEZ-MORENO CALERA, José Manuel. “Arte y Marginación. Las iglesias de Granada a finales del s.XVI", En: Actas de las III Jornadas La Religiosidad Popular y Almería. Almería: Instituto de Estudios Almerienses, 2004., págs. 291-312., pág. 304.

- HENARES CUÉLLAR, Ignacio; LÓPEZ GUZMAN, Rafael. Arquitectura Mudéjar Granadina. Granada: Caja de Ahorros y Monte de Piedad de Granada, 1989.

- LADERO QUESADA, Miguel Ángel. “Los Bautismos de los musulmanes granadinos en 1500". En: VIII Simposio Internacional de Mudejarismo, De mudéjares a moriscos: una conversión forzada. Teruel: Centro de Estudios Mudéjares, 1999, págs. 481-542.

- LÓPEZ DE COCA CASTAÑEZ, José Enrique. "La fiscalidad mudéjar en el reino de Granada". En: V Simposio Internacional de Mudejarismo. Teruel: Instituto de Estudios Turolenses, 1991, págs. 191-220.

- LÓPEZ FERNÁNDEZ, Domingo A . "Los Mínimos de San Francisco de Paula. Precedentes y fundación del Convento de la Victoria en la Villa de Motril.” En: SÁNCHEZ RAMOS, Valeriano (Coord.) Los Minimos en Andalucía. IV Centenario de la fundación del Convento de Nuestra Señora de la Victoria de Vera (Almería). Almería: Instituto de Estudios Almerienses, Ayuntamiento de Vera y Orden Mínima. 2006. págs. 187-237.

- LÓPEZ GUZMÁN, Rafael. Arquitectura Mudéjar. Madrid: Ediciones Cátedra (Grupo Anaya, S.A.), 2000.

- MADOZ, Pascual. Diccionario Geográfico-Estadístico-Histórico de España y sus posesiones en Ultramar: Granada: El nombre del imp. Varía en diferentes vols. Vols. 6-9: Est. Tipográfico-Literario Universal; Vols. 10-11: Imprenta al Diccionario Geográfico, a cargo de José Rojas; Vols. 12-16: Imprenta del Diccionario geográfico estadístico-histórico de Pascual Madoz, 1846-1850.

- MALPICA CUELLO, Antonio. La Costa de Granada en Época Medieval. Poblamiento y territorio. Motril: Ayuntamiento de Motril, 1994.

- MALPICA CUELLO, Antonio. Las últimas tierras de Al-Ándalus. Paisaje y poblamiento del reino nazarí de Granada. Granada: Universidad de Granada, Consorcio para la Conmemoración de la Fundación del Primer Milenio del Reino de Granada, 2014. 
- MARTÍN GARCÍA, Mariano. "Iglesias Fortificadas de la costa granadina". En: Actas del IV Congreso de Castellología. Madrid: Asociación Española de los Amigos de los Castillos, 2012. págs. 713-734.

- MONTES ROMERO-CAMACHO, Isabel. "Las comunidades mudéjares en la corona de Castilla durante el s. XV”. En: VIII Simposio Internacional de Mudejarismo, De mudéjares a moriscos: una conversión forzada. Teruel: Centro de Estudios Mudéjares, 1999, págs. 367-480.

- PAREJA LÓPEZ, Enrique y MEGÍA NAVARRO, Matilde. Salobreña. Datos para su historia. Granada: Diputación de Granada, 1978.

- PEINADO SANTAELLA, Rafael G. "La sociedad repobladora: el control y la distribución del espacio". En: PEINADO SANTAELLA, Rafael G. (Coord.). Historia del Reino de Granada I: De los orígenes a la época mudéjar (hasta 1530). Granada: Editorial Universidad de Granada, El Legado Andalusí. 2000, págs. 477- 524.

- RUÍZ POVEDANO, José María. "Las ciudades y el poder municipal”. En: PEINADO SANTAELLA, Rafael G. (Coord.). Historia del Reino de Granada I: De los orígenes a la época mudéjar (hasta 1530). Granada: Editorial Universidad de Granada. 2000, págs. 611-660.

- SÁNCHEZ REAL, Javier. Iglesia y defensa: las iglesias-fortaleza del Reino de Granada. En: BARRIOS AGUILERA, Manuel (Coord.), GALÁN SÁNCHEZ, Ángel (Coord.), La historia del reino de Granada a debate: viejos y nuevos temas: perspectivas de estudio. Granada: Editorial Actas, 2004., págs. 595-626., pág. 625.

- VV.AA. Guía artística de Granada y su provincia, Vol. II. Granada: Fundación José Manuel Lara. 2006.

Webgrafía:

- www.cofradiasaludyconsuelo.com/fotos-antiguas-iglesia-de-la-victoria-ppagustinos-motril

- $\quad$ www.elfaromotril.es

- $\quad$ www.rinconesdegranada.com 